\title{
失血性急性貫血二對ス儿直接及ビ間接 輸血ノ血液像二關ス儿實驗的比較研究
}

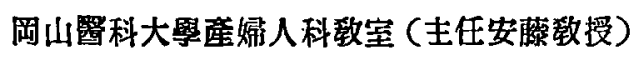

入木齊

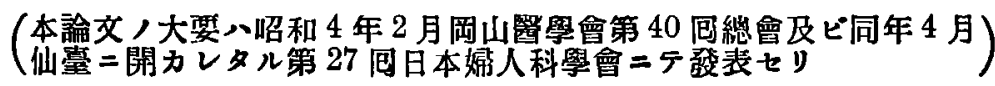

目次

第 1 章 絈 論

第 2 章 研究方法及ビ實驗材料

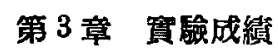

第 1 節 称備試驗

第 1 項 健常成熟家鬼 $/$ 血液像站二其，生理的 日時的動蜎及ビ體溫

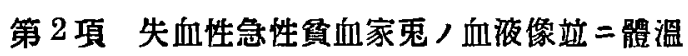

第 3 項 血泎检查，反復二因儿健常家兔，血液 像

第 4 項 夏季及ビ冬季二於ヶル健常家鬼ノ血液 像立二體溫

第 2 節 直接输血 $=$ ヨル失血性急珄貝血家鬼 液像筫化垃二體温

第 3 節构烙酸曹澾血液, 間接鐱血二ヨ几失血性 急性貧血家克，血液像樊化这二體温

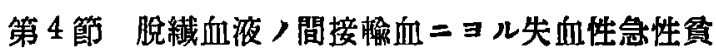
血家鬼 $/$ 血液像禁化竝 $=$ 體温

第 5 節 璟照試驗

第 1 項 生理的食㹂水，静脲內注入二ヨル失血

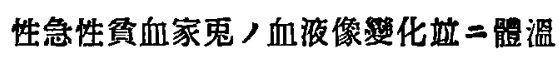

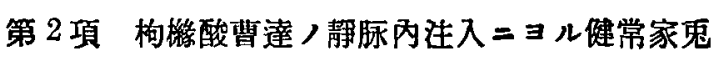
，血液像化端二體溫

第 3 項 血球浮游液, 靜脉內注入 $=$ ヨ几健常家鬼 >血液像䁔化站二體温

第 4 項 煡常家鬼血清, 静疿內注入 $=ヨ$ ル健常家

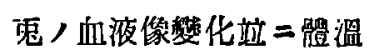

第 4 章 全實驗成縝，總括及ビ考按 第 5 章 結 論

主要文㖪

\section{第 1 章緒論}

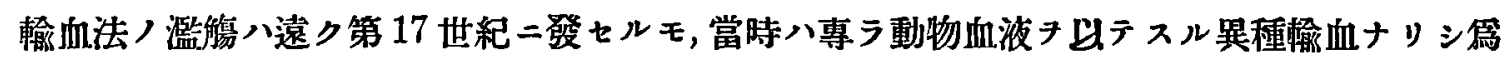

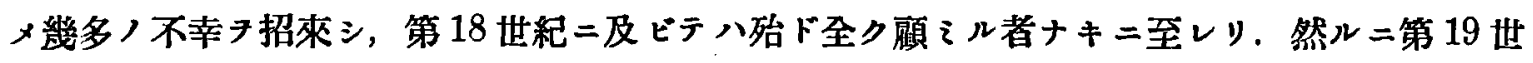
䄫ノ初ハ二至リテ不合理ナル暴種輸血法八同種輸血法二改良セラレ，人二對シテハ人ノ血液タ

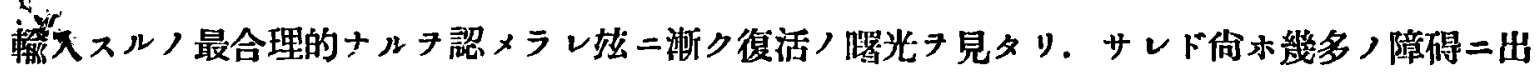

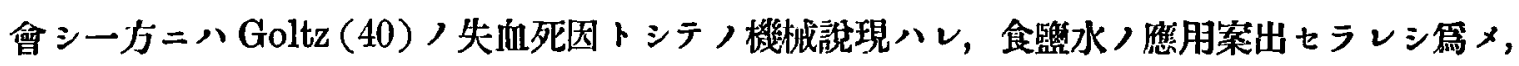

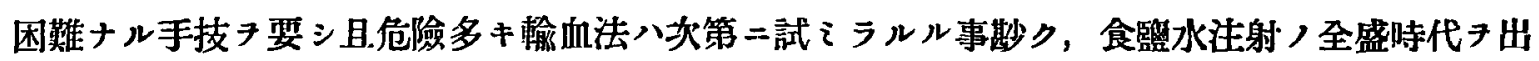

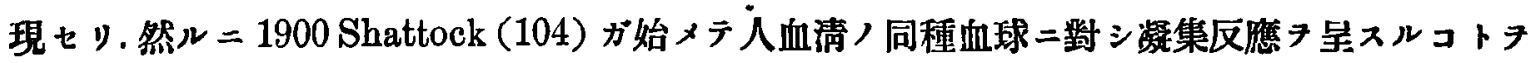


認メシ旦來 Landsteiner $(69,70), \operatorname{Ascoli}(2), \operatorname{Donath}(18,19), \operatorname{Eisenberg}(26)$ 等ニョリ テ做究セ5レ, 更 $=$ v. Decastello u. Sturli (15), Jansky (57), Moss (88), v Dungern u. Hirschfeld (21-24) 等ニョリテ呼究サレ, 人類) 血型 74 型二分類セラルルニ至リテ茲二喻血

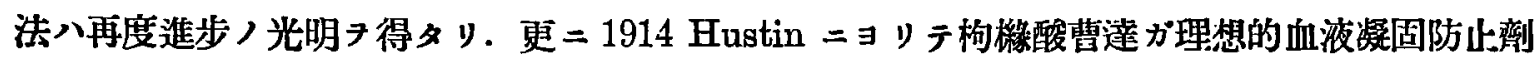
ナル事發見セラレ，其後Agote，Lewisohn (74-76), Weil (116)等ニヨリテ同剂テ加へ非凝 固性トセル血液フ上テスル間接渝血法ノ優秀ナルフ認メラレシ以來, 构椂酸曹達血液ノ間接輸 血法ハ操作籣單ナルタメ一般二普及スルニ至レリ.

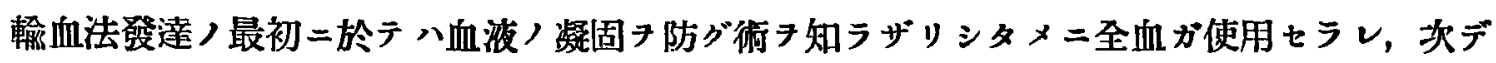
脫織血之二代りタルモ其ノ有害ナルコト制明セラレタルタメ再ビ全血輸血二復セり，サレド血

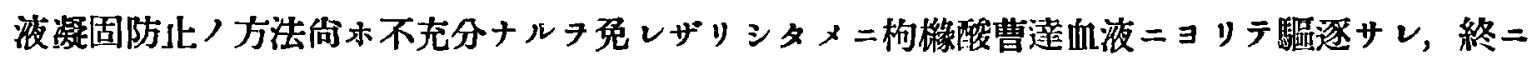
間接輸血法ノ今日ノ隆盛キ見ル二至り現今治療界二缺クベカラザルモノトナリタリ.

然レドモ枸格酸曹達血液二八台木種々ノ副作用アル事渐次制明サルルト共 $=3$ 度些ノ数化 モ與へラレザル全血榆血二歸ラントシッッアルナリ。

枸格酸曹達血液ノ間接输血法二於テハ副作用トシテ發熱, 惡寒, 戰懆, 惡心, 嘔吐, 頭痛, 矓量,

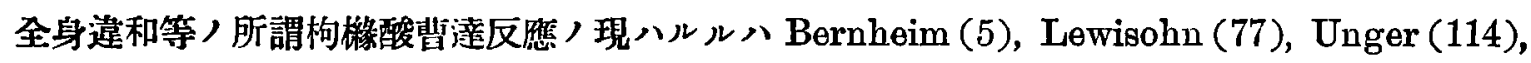
Lederer (73), Fourness u. Lee (133), Nather u. Ochsner (90), Platt (94) 等多數學者)既= 認么ル所ニシテ，其ノ症狀ノ强弱，頻度八各學者ニヨリ暴ナルモ最低 $20 \%$ (Lewisohn), 最高 $60 \%$ (Fournes u. Lee, Unger) ナリト云フ.

直接輸血法二於テハカカル忌ムベキ反應症狀，現ハルルコト甚ダ粆ク，文哭タ徵スル二最高

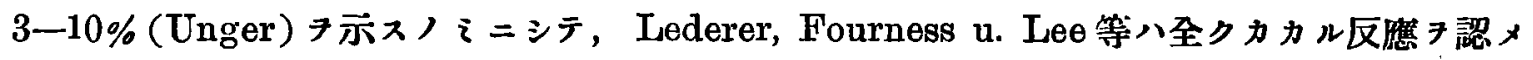
ズト言へリ.

枸䋇酸曹達二カカル毒性フリトセバ生䯤譏能ノ羅針盤タル血液像二最モ著明ナル變化アルベ キハ何人モ容易二考へ得ラルル所ニシテ，既=John (59), Coenen (13), Opitz (92), Unger (113), Vago (115), Rossius (96), 鳥井 (109), 川瀨及ビ藤森等ニヨリテ注意サレタルモ精密ナ

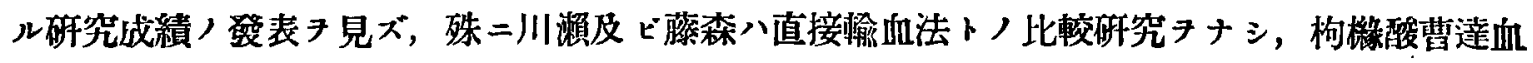

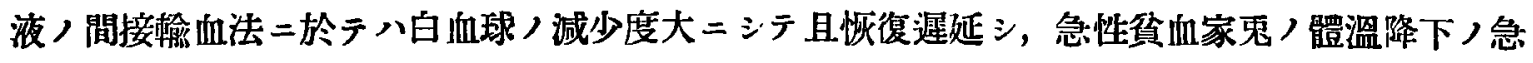
激ナルト血涯ノ恢復狀態ノ本滑ナラザル等ノ障碍的影響ノアルニョリ，枸楼酸曹遵血液，間接 輸血法ハ決シテ直接輸血法二優レリトハ葐スベカラズ，故二吾人ハ輸血ヨ行フニ當リテハ能フ 限リ直接輸血ア行フォ上合理的ナルモノト思考スト言へリ。

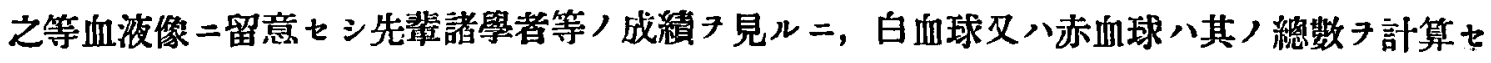

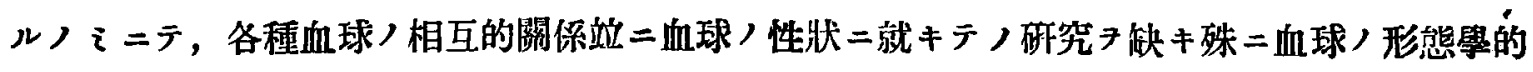

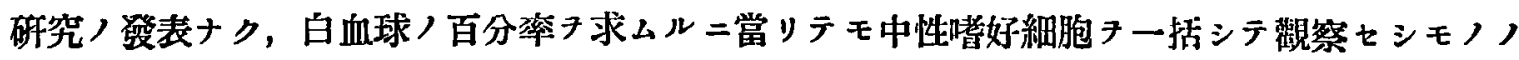
$i=シ テ$, Schilling 氏法ニヨリテ之キ分類シ核形推移ノ程度ヨ究×タルモノナシ. 余八特ニ之

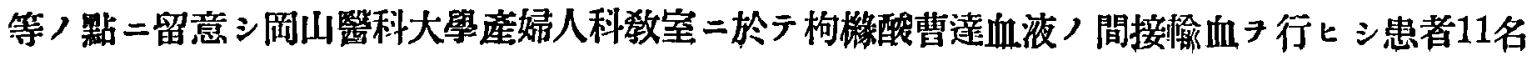




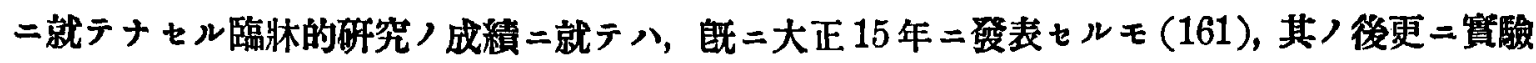

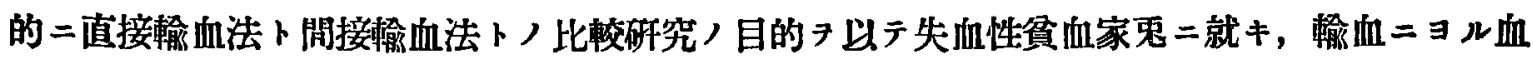

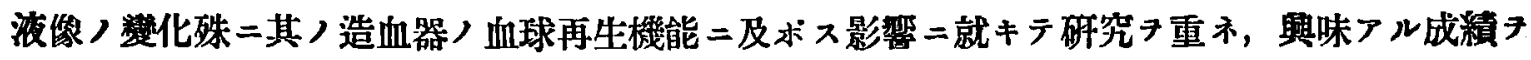
得タルョ以テ茲ニコレヨ報告スル所以ナリ。

\section{第 2 章研究方法及ビ實驗材料}

檢查事項

1. 體溫，體重，其，他一般狀態，觀察.

2. 赤血球，白血球及ビ色彩指數，算定站二血色素量ノ測定.

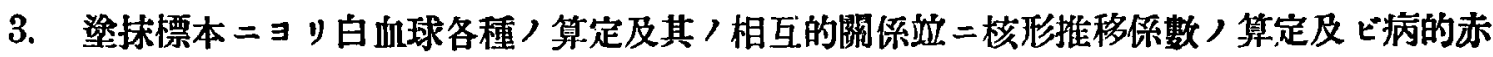
血球站二白血球／有無.

血液檢查方法立二其ノ注意事項

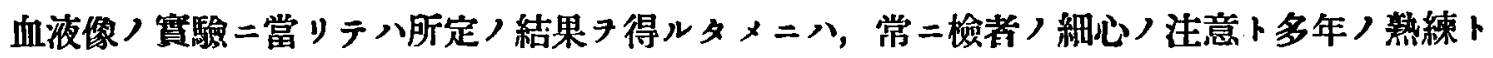
フ要スルコト大ナリ，其ノ檢查方法二至リテモ極メテ少量ノ血中二於テ得タル結果タ，歸納的 二比較結論スルモノナレバ操作上ノ僅微ナル缺陷ニヨリテモ結果ニ多大ノ誤琴ヨ生ズルモノニ シテ，探血ノ方法，稀罢法及ビ血球計算ノ操作法等二八特二注意タ拂へリ。

試獸八體重 $2500 \mathrm{gr}$ 內外)雄性成熟家鬼キ使用シ，毛色ハ總ベラ白色ノモノフ使用セリ。家

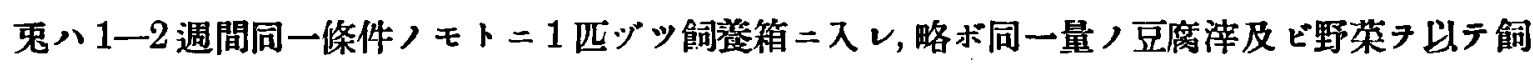

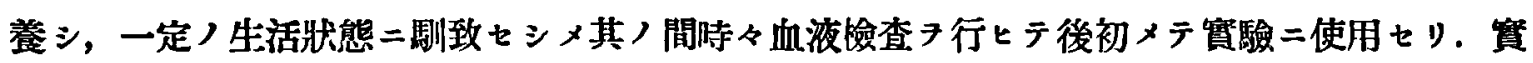

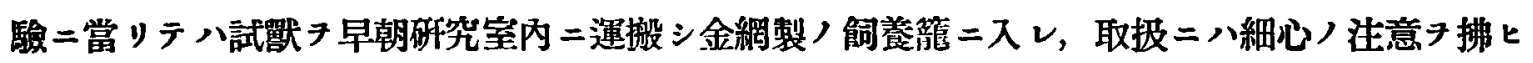

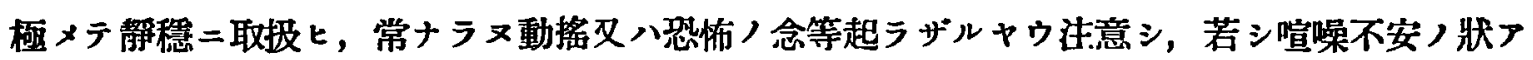
ル時ハ本常ノ狀賏ニ復スルキ待チテ後始メラ採血セリ。

消化性白血球塻多症二關シテハ Nasse, Virchow u. Molechott 以來多數學者〉主張スル所ナ ルモ, Japha (56)，草間 (140) 八人間二於テ. Klieneberger u. Carl (63), 井戶及ビ野木 (134),

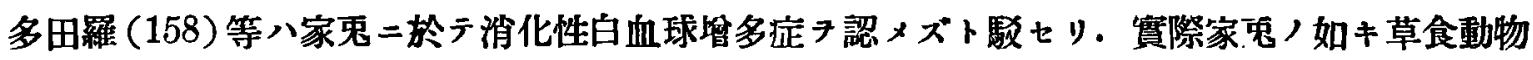

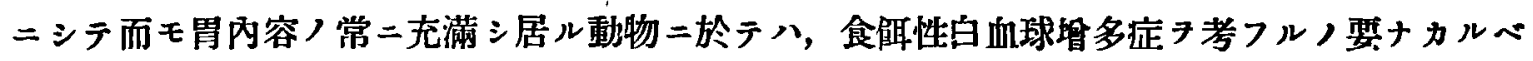

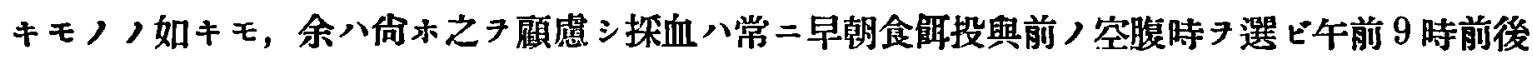

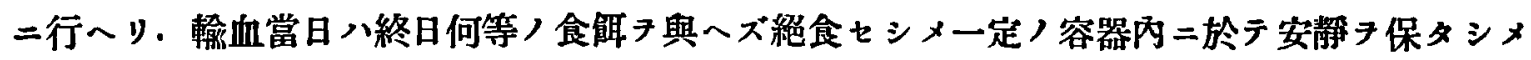

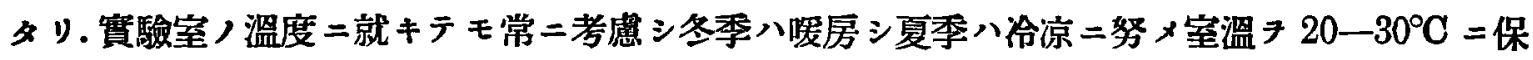

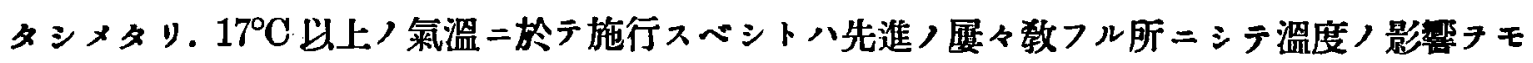
避クタリ。

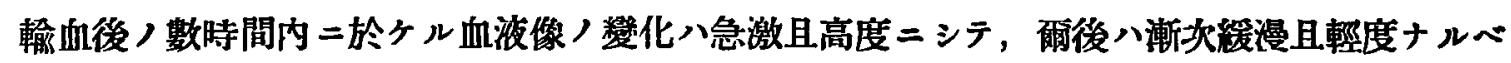

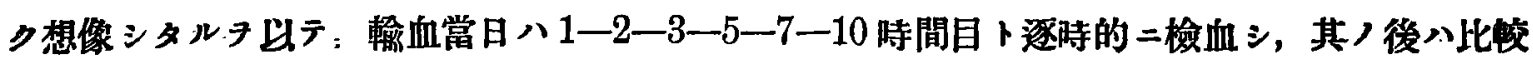




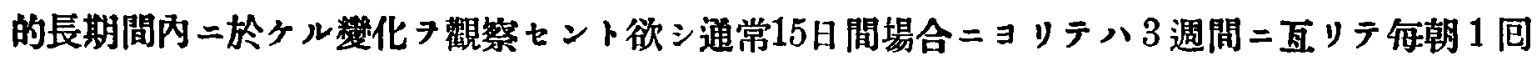
逐日的二检血七リ。

檢血ハ輸血

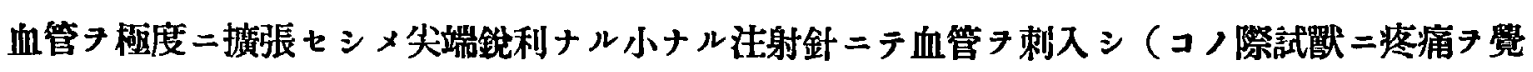

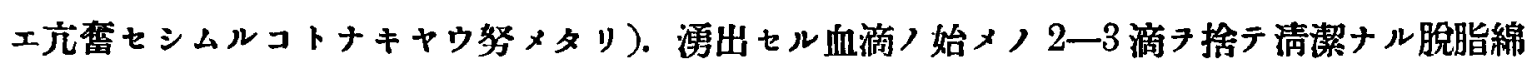
二テ拭去シ, 自然二涌出スル血滴ヨリ先ッ叙抹慓本ヨ作り次デ白血球, 赤血球, 血色素ノ順二 行へリ. Klieneberger (63), 多田羅 (158) 等ノ言へル如ク刺傷ハ每回新タナル筒所キ選ビ, 前 回ノ刺傷ヨリモ常二約 $1 \mathrm{~cm}$ 位ノ間隔ヨ置キテ刺傷ヨ作リ探血スルコトトセリ．最初ハ耳靜脉 ノナルベク根部二於テ探血シ逐次间フ追フテ末梢部ニテ探血シ, 血管タ同一程度二怒張セシル

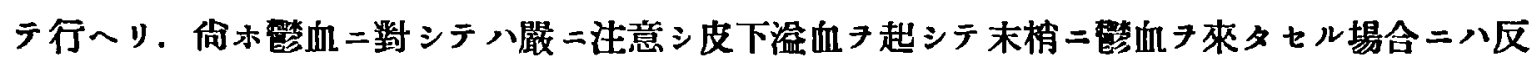
對側ノ耳静脉习使用セリ。

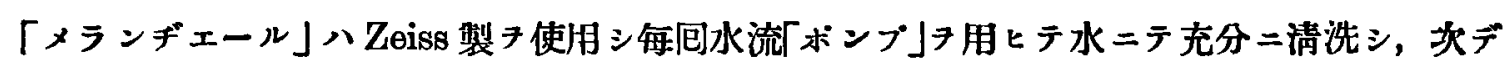
監酸「アルコール」フ通ジ脫水シ後「エーテル」ニテ乾燥セシメ内部ノ硝子球が自由ニ移動スル

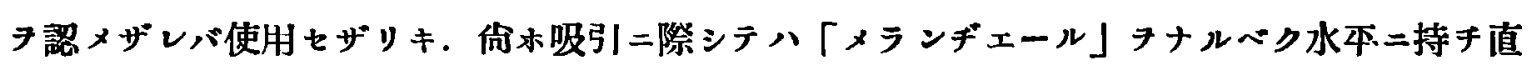

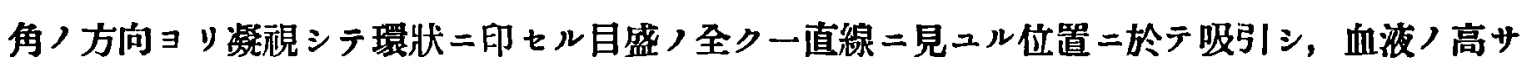
ヨシテコノ目盛ニー致セシメタリ.「メランヂェール」ハ静カニ少クトモ約 1 分間八之ヨ常二水

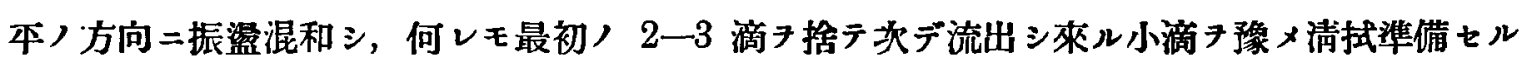

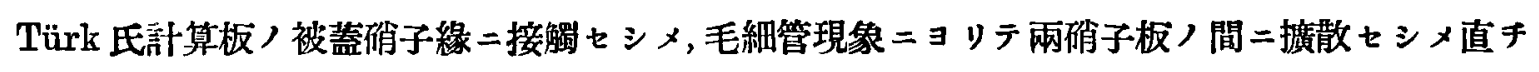
二水本二位置セシメ, 2-3 分間静置シ計算室上二血球ノ本等二散在スルヤ否ヤタ檢シ後計算セ リ. 計算八劃目ノ一隅ヨリ初メ鼾角線狀二科メ二他ノ一隅二向ッテ順次二計算シ, 同一ノ「メ ンヂェール」ヨリ 2 包混液キ交換シテ計算シ後雨者尹本均セリ. 白血球ハTürk 氏液ニテ 20 倍

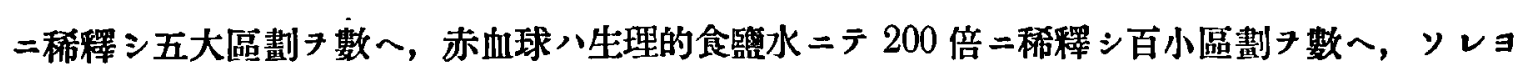
リ血湤 1 立方 $\mathrm{mm}$ ，數テ算出セリ. 白血球數ニ於テッ500 前後八常二現ハレ來タル差數ニシテ

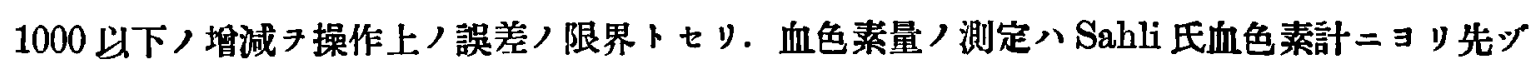

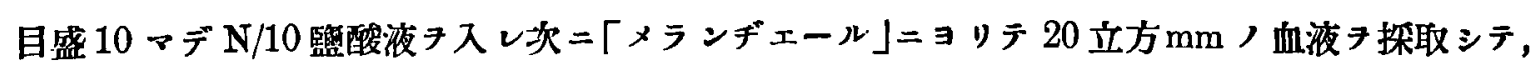

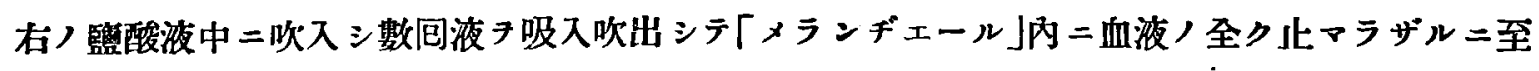

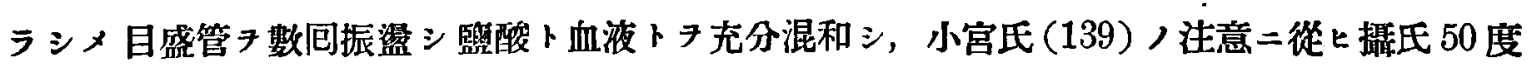
ノ卵卵器中 $=10$ 分間放置シテ Nachdunkeln ヨ全ク顧虑スルノ必要ナカラシメタリ：其ノ後所

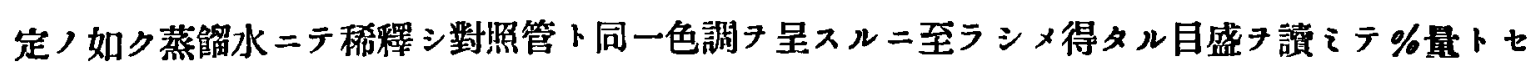
リ。

色彩指數ハ從來色素指數ト奮譯セラレシモノナルモ，多田羅氏ノ意見二同意シ余モ亦カク呼

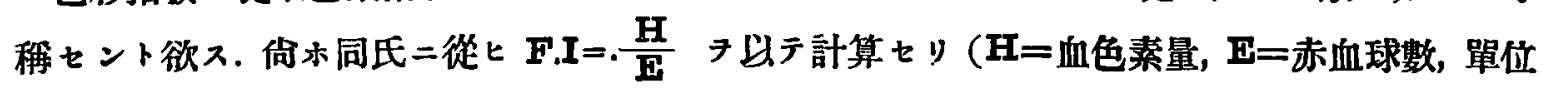
尹10萬卜ス).

塗抹標本ハ先ヅ其 製作ニアタリテハ豫メ載物硝子ハAlkohol-Aether 等分液中二數日間投 
入シ後清拭乾燥セシメ、載物硝子尹古手ノ捚指ト中指トニテ水本二保持シ, 創口ヨリ新タ二涌

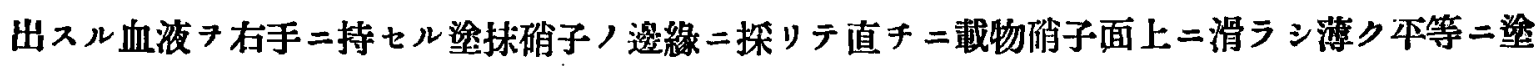

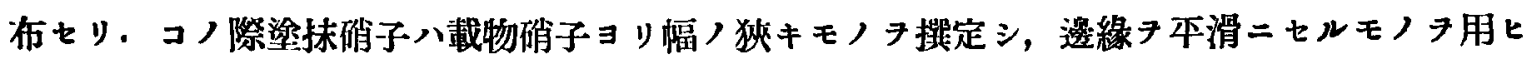
タリ．標本ハ每间 6 枚テ作製シ塗抹シ終レバ室溫中ニテ充分二乾燥セシメ. Methylalkohol = テ約 5 分間固定シ乾燥後 Romanowsky-Giemsa 氏法ニヨリAzureosin 液尹使用シ, 1 枚 標本

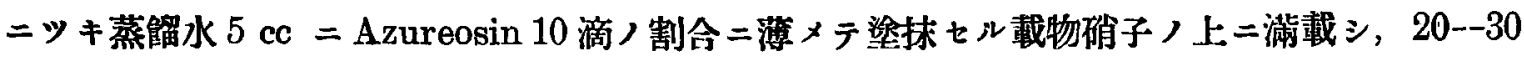
分間染色三後水洗彰燥セリ.

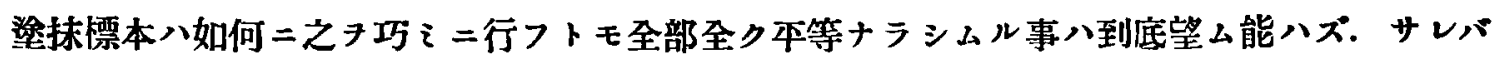

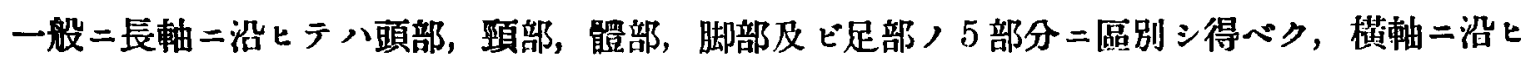

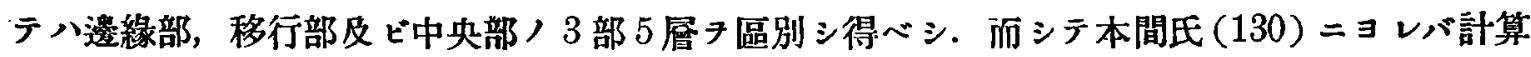
二最モ適當シタル部位八體部ニシテ，赤血球的二白血球各種ノ分布证調ニシテ頭部ハ一般二中

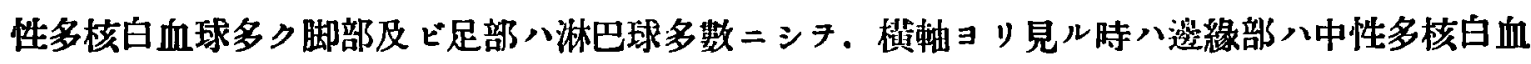

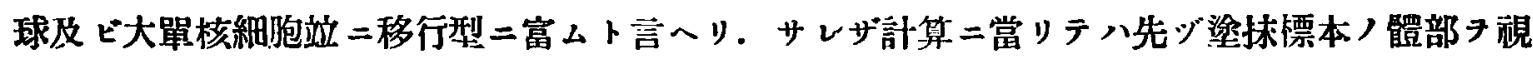
野二入 ，橫軸二沿七テ傻緣部，移行部次二中央部ト次第二計算シ，如斯シテ數回多キ八十數

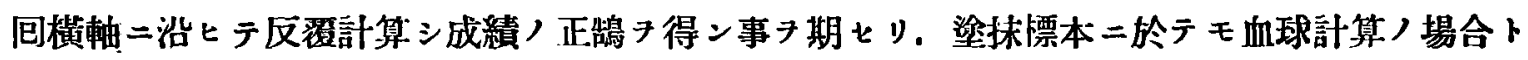

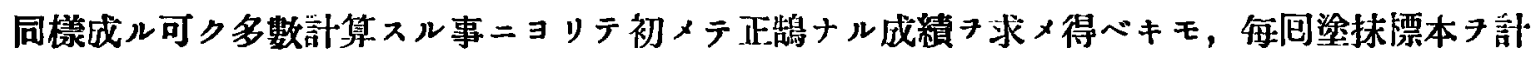

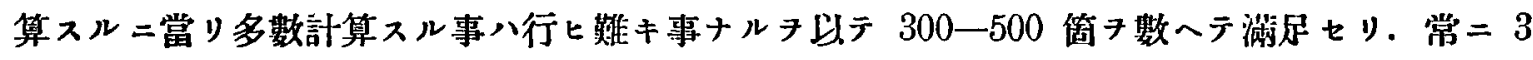
枚ノ標本二就キテ計定セり. 白血球各種ノ區分法ハSchiling 氏法二颜七

B.一盵胖細咆

E.一「エオシンン嗜好細胞 (以下「エ」嗜 好細胞卜略記 ス)

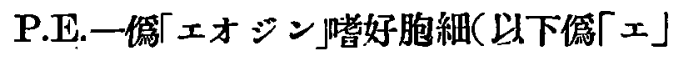
嗜好細胞卜略記ス)

M.一同上骨㖃細胞

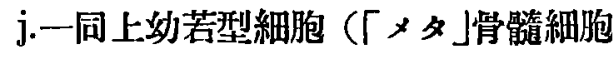
尹モ含么)

St.一同 上桿狀型細胞

S.-一同上多核型細胞

Ly.一淋巴球

Mon.一單核細胞及ビ移行型

卜分類セリ．余八佾ホ核形推移係數 (Kernverschiebungsindex 余ハ之ョ K. V.I.卜略記セリ)

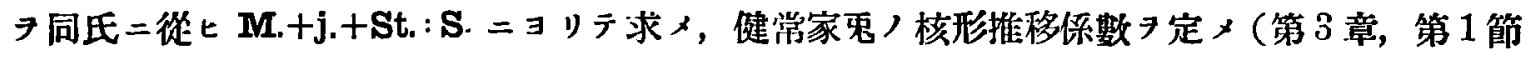

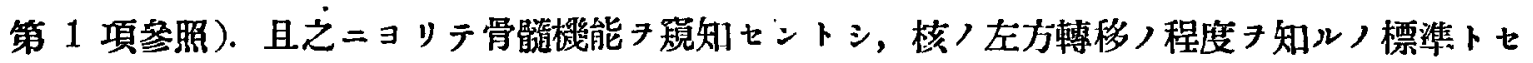
リ.

赤血球中ノ多染性赤血球，大小不同症，有核赤血球，監基性顆粒赤血球等ノ检索八，余八白 血球百分率計算ノ際二於ケル其ノ出現ノ程度二依リテ，一(全ク認メラレザルモノ)、士(數視野

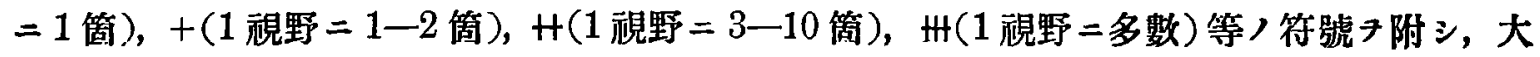
體其ノ多家フ現ハスコトトセリ。

顯微鏡八移動裝置ヨ備装セル・Zeiss 製尹使用シ，接眼「レンズ」4，接物「レンズ」Homong， Immer $1 / 12$ 丹用ヒ油浸装置ニヨレリ。 


\section{輸血法}

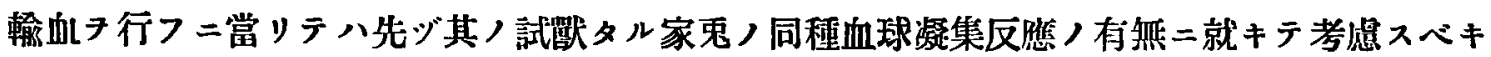
モノニシテ, Landsteiner (71) ハ之キ證明スルモ, Klein (62)八之二反シテ該反燞フ認メズト

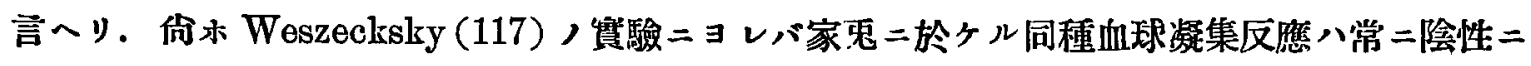

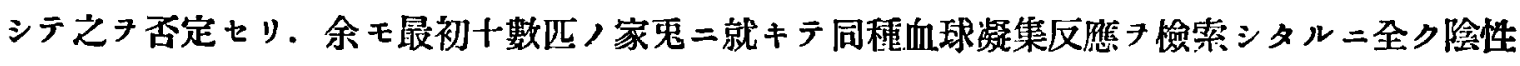
二終レリ. 故二余モ亦 Klein, Weszecksky ノ言へルガ如ク家鬼ニ於クル同種血球凝集反䣸タ否 定スルモノニシテ，余八輸血二際シテハ爾後全ク之タ考虑セズ同種血球凝集反倠ノ檢查 行フ コトナク輸血ヨ行へルモ，未ダ 1 例ニモ危險二遭遇シタルコトナシ. 榆血ヨ行フニハ先ジ前日

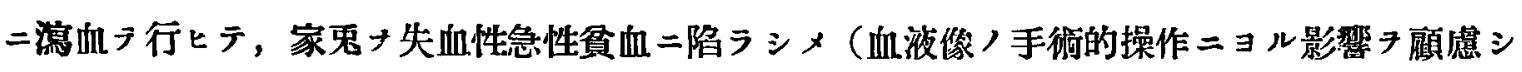

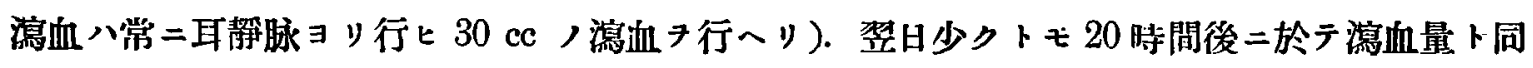
量ノ輸血タ行へリ。

\section{直接輸血法}

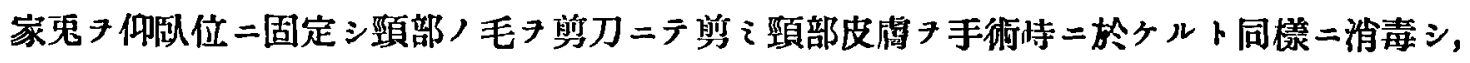

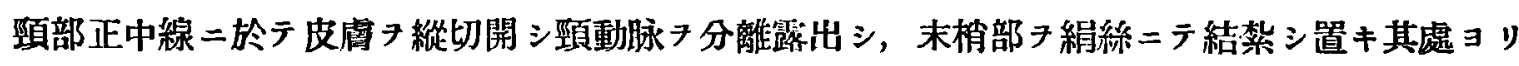

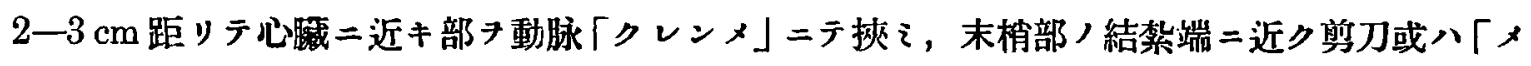

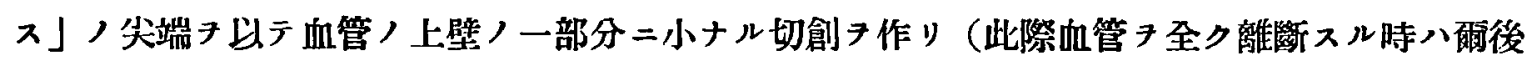

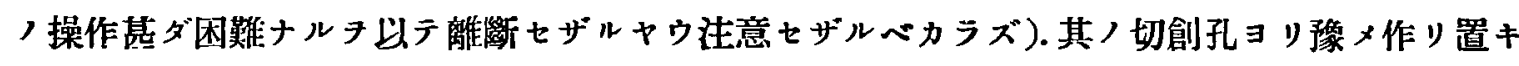

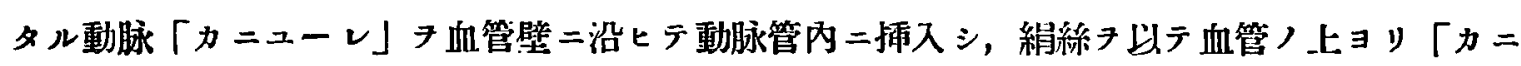
ユーレ」フ結紮固定シ，動脉「カニニーレ」他端ニハ $3-5 \mathrm{~cm}$ 位ノ短キ「ゴム」管キ連接シ置キ 注射器二連結セシムル二便二セリ．カクシテ豫メ消毒シ殺菌食監水二テ溫メタル20-50 cc， 注射器丹「カニューレ」連結シ, 助手ヨシテ「クレンィ」タ除去セシムルト共二迅速二注射器 , Stempel タ引ク時ハ頸動脉內ノ血液ハ「カニューレ」タ通リテ注射器內二流入シ, 所要量,

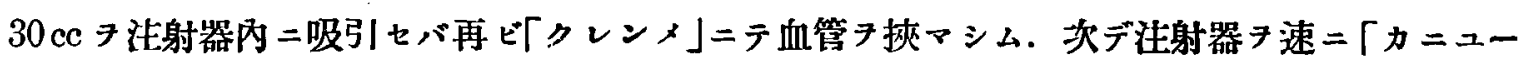
レ」ヨリ離シ其ノ先キニ注射針テ付ケ，注射器內ノ血液ア迅速二豫メ木裴動物固定箱二固定シ

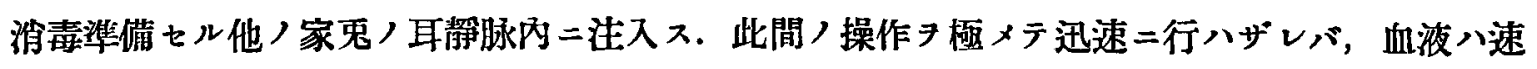
二凝固シテ, 輸血テ逐行スルコト能ハザルニ至ル。モシ 1 回ノミニテ所要量/輸血ヨ行フ事能 ハザリシ場合ニハ2间二分チテ行ヒシ事フリ.

\section{間接輸血法}

\section{1、构椂酸曹達血液, 間接谕血法}

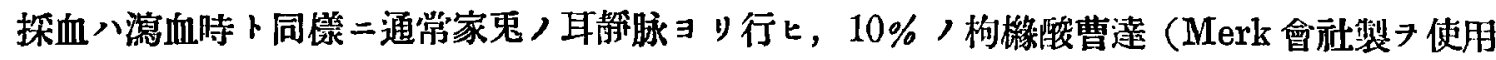
セリ) $1 \%$ 割合二混ジテ凝固タ防ギ全量 $30 \mathrm{cc}$ キ取リ, ヨク混和シ後「ガーゼ」フ 2 重ニシテ 2 尼滤渦シ, 體溫二盜メテ耳静脉ヨリ徐々二輸血七リ。 
2. 脫緎血液, 間接輸血法

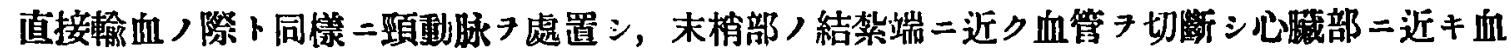
管ノ斷端ノ一部タ注射針ニテ刺シ，動脉「クレンハ」ヨ除去シ，消毒セル「メスチリンデル」內へ

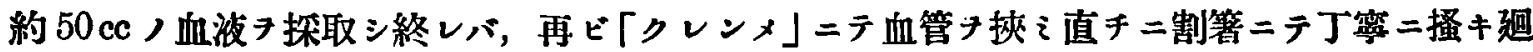
シテ脫繊維素シ，後「がーゼ」ニテ滤過シ 1 時間室溫二放置シ或 $40^{\circ} \mathrm{C}=$ テ 30 分間放置シ後體

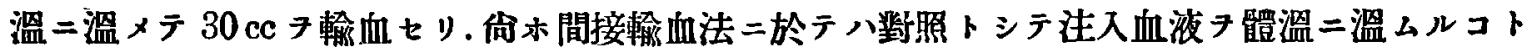

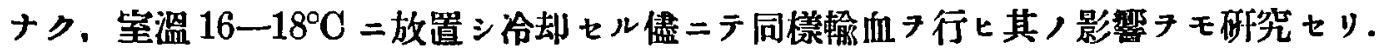

\section{體溫测定法}

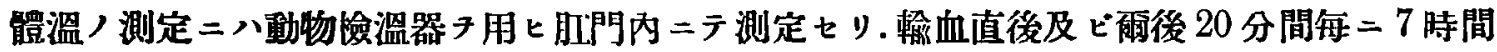

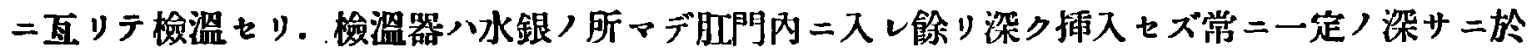

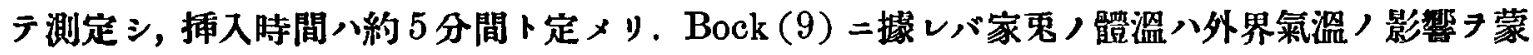

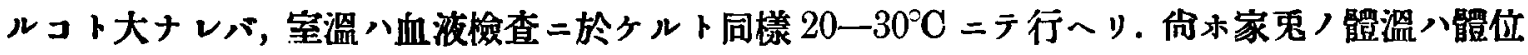

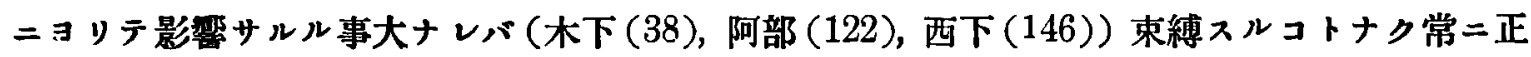
常體位二於テ行へリ.

能重秤量

體重ハ每朝 1 问檢查前二科量セリ.

\section{第 3 章 實 驗 成 綪}

第 1 節 像 備 試 驗

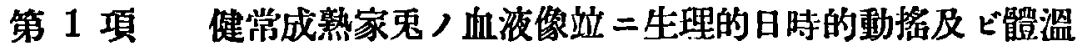

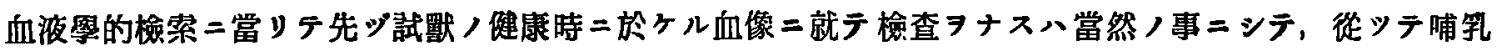

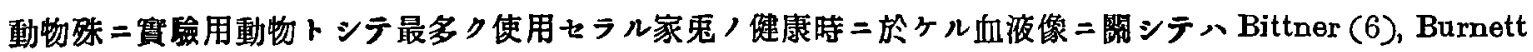
(11)，Domarus (17)，Goodall (41)，Klieneberger u. Curl (63)，井戸及ビ鉿木 (134)，多田羅 (158)，高森 (156)，坂田 (152)，福井 (123)，大野 (150)，日野 (128) 其／他多數，先輩二依りテ既二研究サレ其業續甚 ダ多シ. 今家鬼ノ血夜像所見 $习$ 總括シ餘ノ 88 匹二於ヶル成績ト比校對比スル二次ノ如シ.

赤血球 赤血球數八文哭 $=\Xi ル=$ 最低 310 萬 (Otto (93)), 最高 900 萬 (Pröscher (128) =シテ, 大體

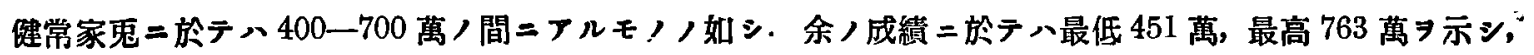

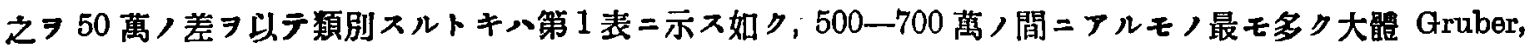
Scholz, Werzberg, 多田羅, 高森等/成續二近似又.

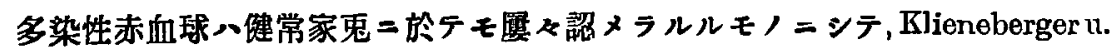
Carl ヘ40:1ナリトスルモ，余ノ成績ニ於テハ多クハ輕度ニシテ高度ナルモ，

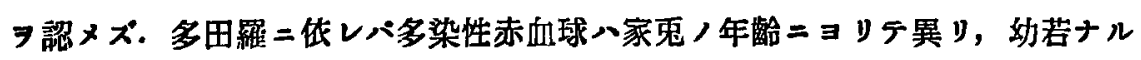

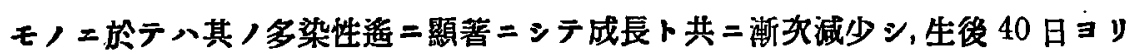
其/程度ハ成熟セルモノニ於アルト大差ナキニ至ルガ如シト言ーリ。

第 1 表

\begin{tabular}{c|c}
\hline 赤血球數 & 頭數 \\
\hline 500 以下 & $\dot{2}$ \\
$500-550$ & 15 \\
$560-600$ & 23 \\
$610-650$ & 23 \\
$660-700$ & 15 \\
700 以上 & 10
\end{tabular}




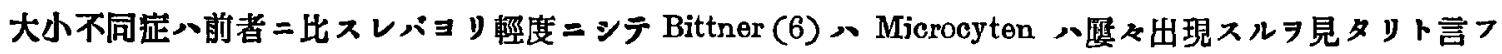

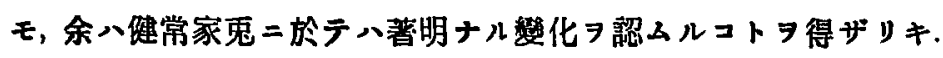

有核赤血球 N Bittner (6), Gruber (48), Domarus (17), Klieneberger u. Carl (63) 等，正常家鬼血液=

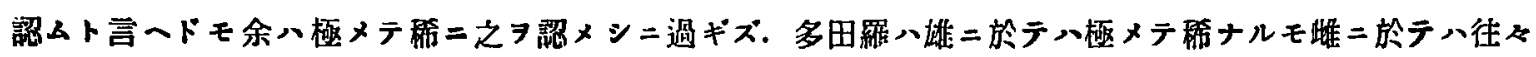

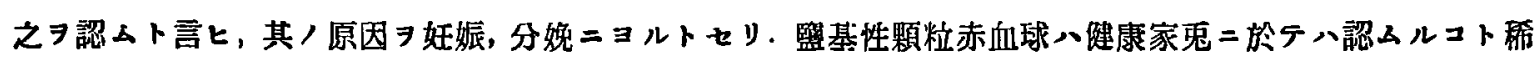

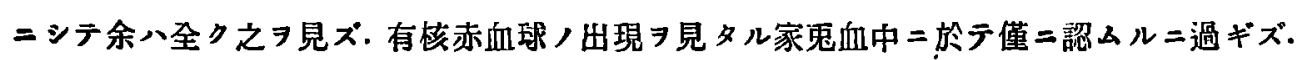

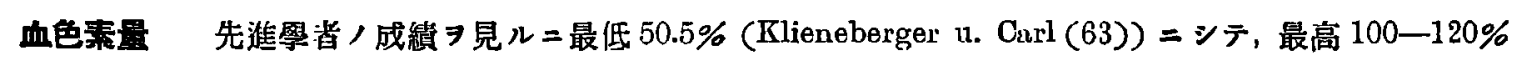

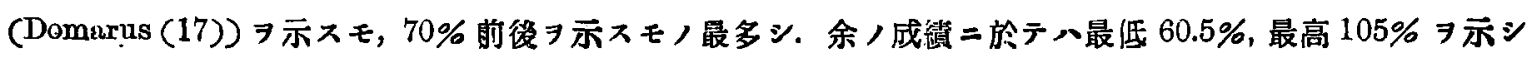

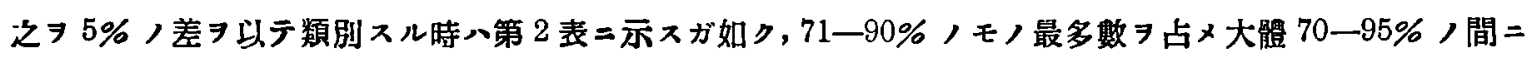

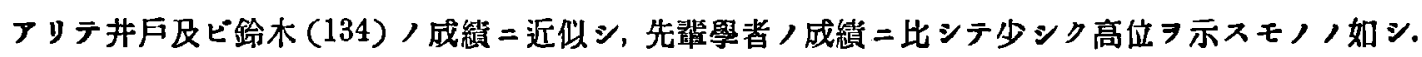

色彩指數＼cjkstart從來家克二於ヶル色彩指數ノ詳細ナルモノナカリシモ、多田羅

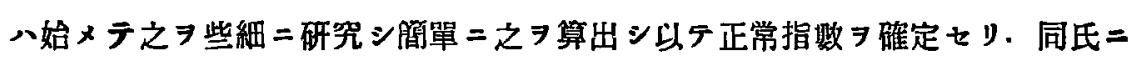

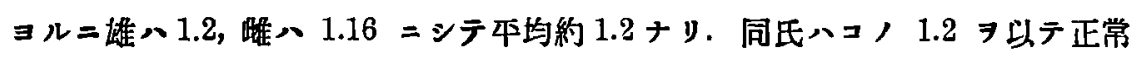
成熟家鬼ノ色彩指數トシコノ值ヨリ大ナル或ハ小ナル指數 Hyperzy tochromämie 或、Hypocytochromämie ト稱セント欲スト言へルモ.

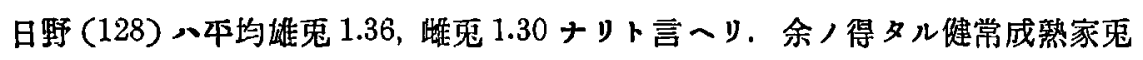
八色彩指數 70.05 人差 $习$ 以テ類別スルトキ八第 3 表二示ズガ如ク最低 1.16 , 最 高 1.45 ニシテ，大多數、1.31-1.40 ヨ示シ略ボ日野ノ成結二近似シ，多田羅二 比シテ少シク高位 $\ni$ 示セリ.

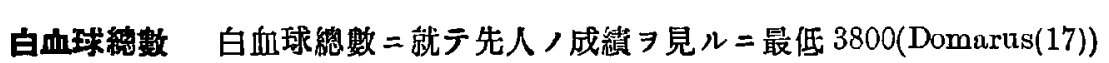
ニシテ, 最高 15600 (高森 (156)) ヨ示シ大體6000-13000，間二位スルモ， 如シ. 余ノ成績 $=$ 就テ見ル $=$ 最低 3720 , 最高 15040 示シ, 之 1000 ノ差 7 以 テ類刷スルトキハ第 4 表二示スガ如ク 6000-11000/モノ其ノ大多數 大體 4000-15000 間=位シ, Pröscher, Cruber, Willirmson ノ成綪ト一致シ, 尚ホ多田羅氏ノ言一ル如ク余モ亦 15000 以上ノモノハ何等カ異狀アルモノニシ テ，凟驗動物トシテハ不適當ナルモノ，如ク思考セラル。

白血球各種ノ百分率交暗习案ズル二健常家鬼二於ヶル白血球各種ノ百分 率二就テハ諸家ニョリテ差異甚ダシク一定セザルモ, 人體ニ於ヶルョリモ淋巴

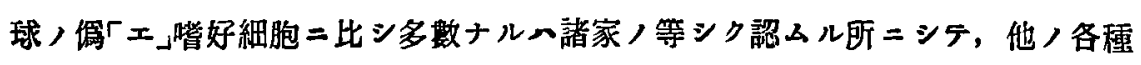
細胞八少數ノ百分率二於テ存在スルニ過ギズ．余ノ成綨二就テ見ルモ淋巴球八

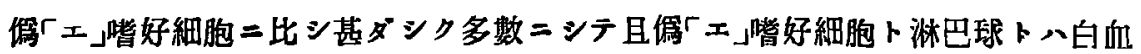
血球中最多數 ヨ占メ兩者ノ數皇的關係ハ概ネ正反䍌ナシ.サレド其ノ和八略ボ

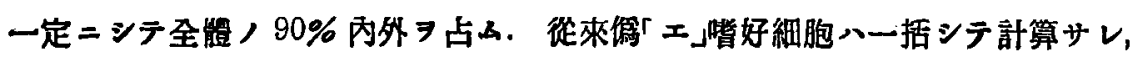

第 2 表

\begin{tabular}{|c|c|}
\hline 血色䋜量 & 頭數 \\
\hline $\begin{array}{c}70 \text { 以下 } \\
71 \text { 年5 } \\
76-80 \\
81-85 \\
86-90 \\
91-95 \\
96-100 \\
100 \text { 以上 }\end{array}$ & $\begin{array}{r}1 \\
17 \\
19 \\
18 \\
18 \\
9 \\
3 \\
3\end{array}$ \\
\hline
\end{tabular}

第 3 表

\begin{tabular}{l|r}
\hline \hline 色彩指數 & 頭數 \\
\hline $1.16-1.20$ & 5 \\
$1.21-1.25$ & 11 \\
$1.26-1.30$ & 8 \\
$1.31-1.35$ & 23 \\
$1.36-1.40$ & 31 \\
$1.41-1.45$ & 10
\end{tabular}

第 4 表

\begin{tabular}{|c|c|}
\hline 白血球數 & 頭數 \\
\hline $\begin{array}{l}4000 \text { 以下 } \\
4000-5000 \\
5000-6000 \\
6000-7000 \\
7000-8000 \\
8000-9000 \\
9000-10000 \\
10000-11000 \\
11000-12000 \\
12000-13000 \\
13000 \text { - } 14000 \\
14000 \text { - } 15000 \\
15000 \text { 上上 }\end{array}$ & $\begin{array}{r}1 \\
2 \\
6 \\
8 \\
12 \\
20 \\
13 \\
8 \\
5 \\
2 \\
7 \\
3 \\
1\end{array}$ \\
\hline
\end{tabular}


Sohilling 法二做ヒテ之

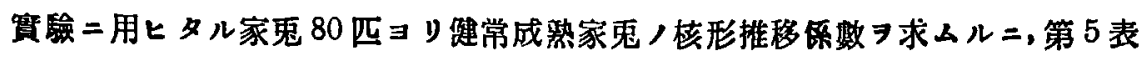

二示スカ如り最低 0.06 , 最高 0.33 э示シ， $0.16-0.20$ 間二位スルモ/最多數

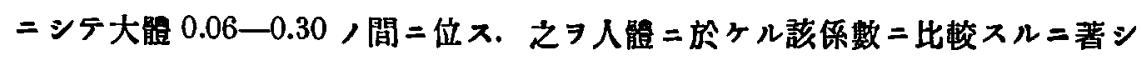
ク大ニシテ 2-3 倍ヨ示スモノ多シ.

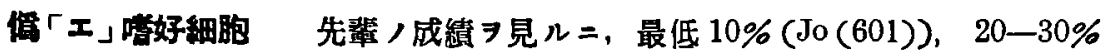
(Kunthack u. Hardy (128)), 最高 44.2-67.7\% (高 森 $(156)$ ) =シテ, 大體二於テ 30-50\% 八最多シ。余, 成縝 7 通覽スル 高 73.0 ニシテ, 大體 20 - $60 \%$ ノ間ニアルモノ最 多ク Dumoulin，成績＝近似又（第 6 表壆照）.

捍状型細胞 余ノ成績 $\exists$ 總括スル $=$ 最低 $1.0 \%$ シシテ最高 $12.7 \%$ ヨ示シ，2-8\% 間二位スル モノ最多ク多田羅，日野ノ成績二比シ少シク高位. ニアリ (第 7 表绑照).

幼若型細胞 俈常成熟家兔/血中二於テモ少

\begin{tabular}{|c|c|}
\hline $\begin{array}{l}\text { 俘「工貲好 } \\
\text { 細胞 (\%) }\end{array}$ & 頭數 \\
\hline $\begin{array}{l}20 \text { 上下 } \\
20-25 \\
26-30 \\
31-35 \\
36-40 \\
41-45 \\
46-50 \\
51-55 \\
56-60 \\
61-65 \\
66-70 \\
71-75\end{array}$ & $\begin{array}{r}3 \\
9 \\
9 \\
10 \\
12 \\
8 \\
6 \\
9 \\
7 \\
3 \\
3 \\
1\end{array}$ \\
\hline
\end{tabular}

\begin{tabular}{c|r}
\multicolumn{2}{c}{7 第 7} \\
\hline $\begin{array}{c}\text { 表桿狀型細胞 } \\
(\%)\end{array}$ & 頭政 \\
\hline $1-2$ & 1 \\
$2-3$ & 10 \\
$3-4$ & 17 \\
$4-5$ & 9 \\
$5-6$ & 14 \\
$6-7$ & 9 \\
$7-8$ & 7 \\
$8-9$ & 2 \\
$9-10$ & 3 \\
$10-11$ & 4 \\
$11-12$ & 2 \\
$12-13$ & 2
\end{tabular}

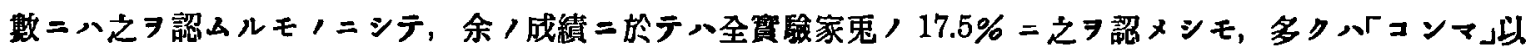
下ニシテ $1 \%$ 以上ニ及ブコトナシ.

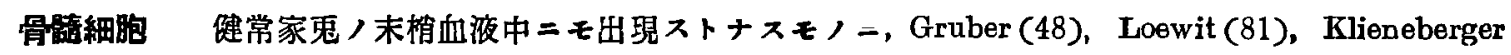

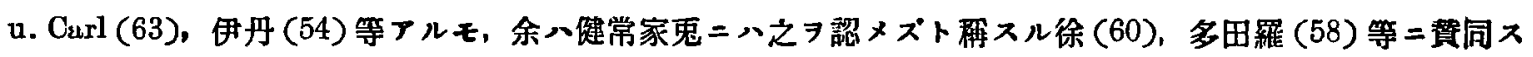

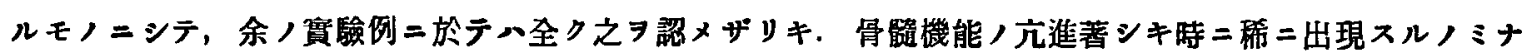
y.

淋巴球先人,成綪 $\exists$ 見 $ル=$ 最低 10-30\%(Dumoulin(128)), 20-25\%(Tullq vist u. Willebrand(108)) 最高 60-65\% (Pröscher (128))，70-80\% (Kanthack u. Bardy (128)) $\exists$ 示シ, 30—50\% ，間二 位スルモ/最多キガ如シ. 余ノ成續二就テ見ルニ 最低 $23.3 \%$ ，最高 $79.7 \%$ э示シ，41-65\%ノモ 八最多ク大體Werzberg (128), Ziegler (128) 八成

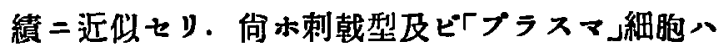
健常家鬼二於テハ殆ド認ムルコトナク造血器ノ刺 載狀態時ニ於テノミ出現スルモノナリ(第 8 表鉒 照).

\begin{tabular}{|c|c|}
\hline 淋巴球(\%) & 頭数 \\
\hline $\begin{array}{l}20-25 \\
26-30 \\
31-35 \\
36--40 \\
41-45 \\
46-50 \\
51-55 \\
56-60 \\
61-65 \\
66-70 \\
71-75 \\
76-80\end{array}$ & $\begin{array}{r}3 \\
1 \\
6 \\
5 \\
11 \\
3 \\
8 \\
13 \\
13 \\
8 \\
6 \\
3\end{array}$ \\
\hline
\end{tabular}

\begin{tabular}{c|c}
\multicolumn{2}{c}{ 第 9} \\
\hline \hline 單核細胞(\%) \\
\hline 1 頭数 \\
\hline $1-2$ & 1 \\
$2-3$ & 9 \\
$3--4$ & 19 \\
$4-5$ & 20 \\
$5-6$ & 17 \\
$6-7$ & 4 \\
$7-8$ & 8 \\
& 2
\end{tabular}

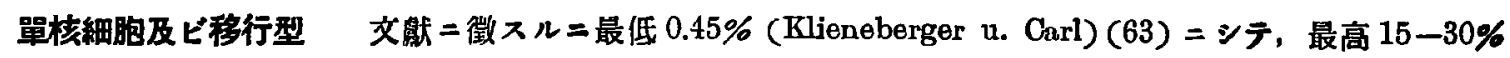
(Dumoulin) 20-25\% (Tullqvist u. Willebrand) (108) ヨ示セリ. 余/成績 $8.0 \%$ ニシテ，大多數ハ2-5\%，間=位シ Kunthnck u. Hardy, Brinkerhoff u. Tyzzer (123), Werzberg, 高

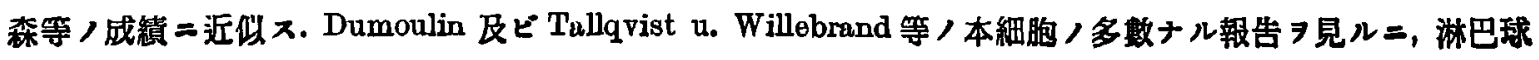




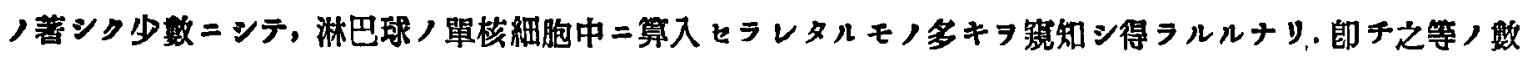

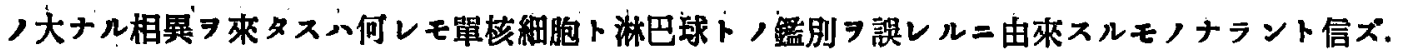

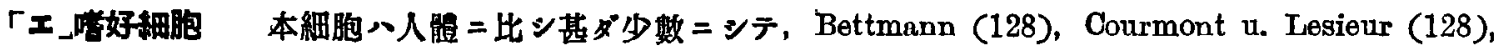
Jo (60), Muir (128), Okintschitz (128) 氏等ハ全ク本細胞ヨ認メザルモノノ如ク，之二反シテ Mezinceseu

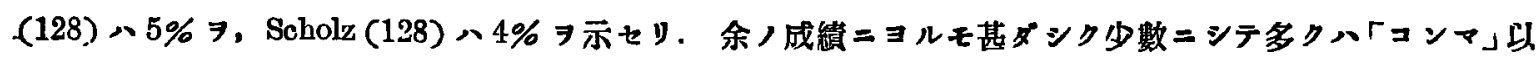

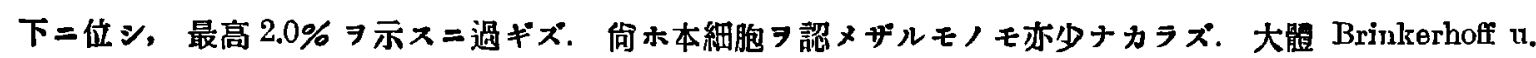
Tyzzer, Domarus, Gruber, Loewit, Pröscher, 井戸及ビ鈴木, 日野, 高森, 多田羅等, 成䋶二近似ス.

肥㭌細胞 Bettmann, Courmont v. Lesier, Murie, Niooa-Froument, Okintschitz, Scholz 等八全ク本

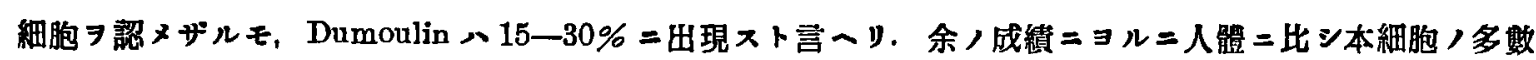

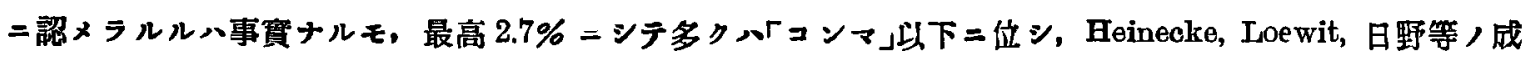
績二近似ス. 向ホ本細胞ヨ缺如スルモノモ亦少ナシトセズ.

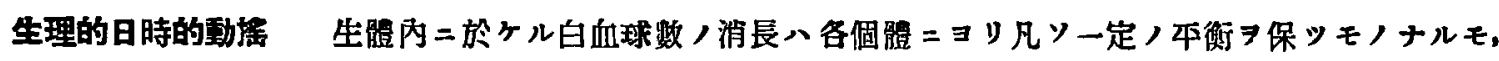

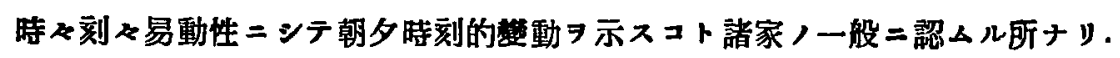

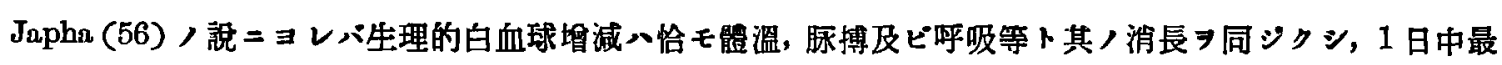

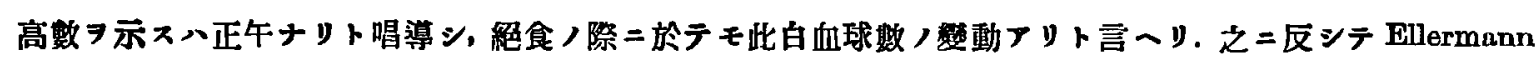

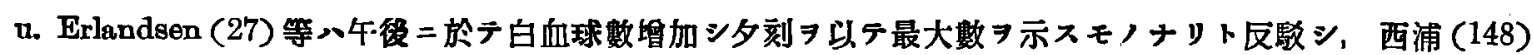

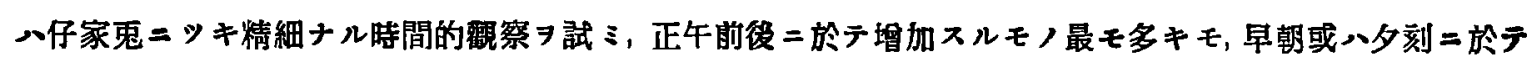
最高ヨ示スモノ必ズシモ少シトセズト言ーリ. 向ホ草間 (140), A. v. Bonzdorf (10), Kobryner (64) 等、人

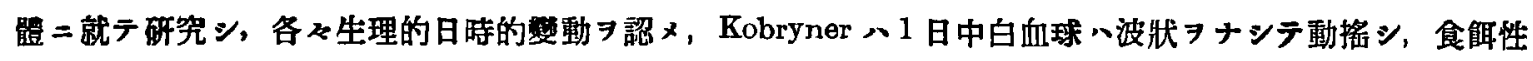
白血球增減八畢竟コノ動播中ニ入ルベキモノナリトセリ. 草間ハ日常生活 $\Rightarrow$ 營ム人二於テ研究シ, 白血球ガ 最大ヨ示ス時刻入正午前後ナルコト最多ケレドモ, 早朝又ハ夕刻ナルコトモ決シテ少シトセズト言ーリ. 问 ホ書間ノ身體安靜時及ビ依間睡眠中二八畫間執奨中ョリモ白血球數著シク少シトセリ. 而シテ之等ノ增減

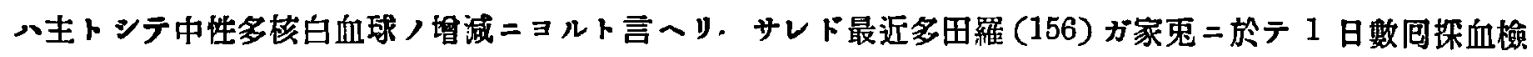
㥀シタル結果ニヨレパ，消化珄或八日時的白血球增多ハ認メズトセリ.

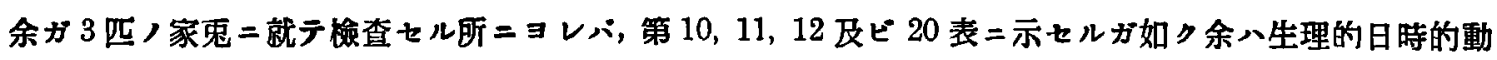

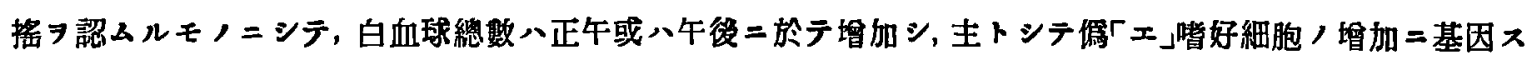

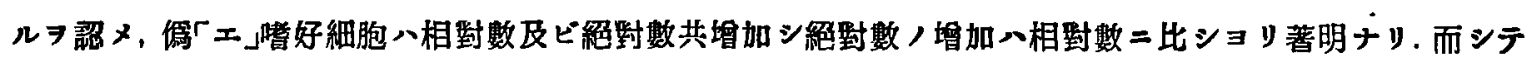

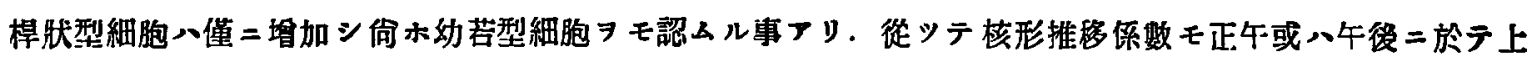
昇ヨ示ス.サレバ生理的日時的動搖八單=Schilling /所謂分布性白血球增多

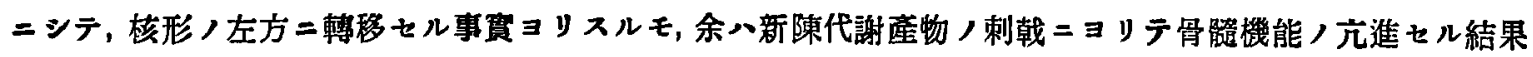
ナリト思考スルモノナリ。

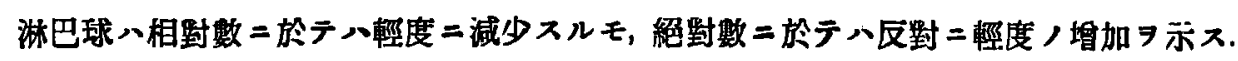

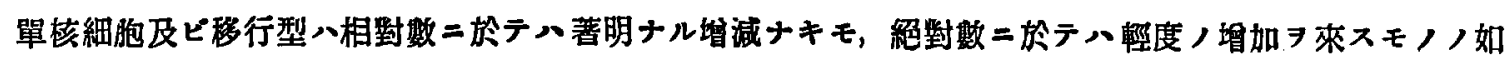
$\%$ 


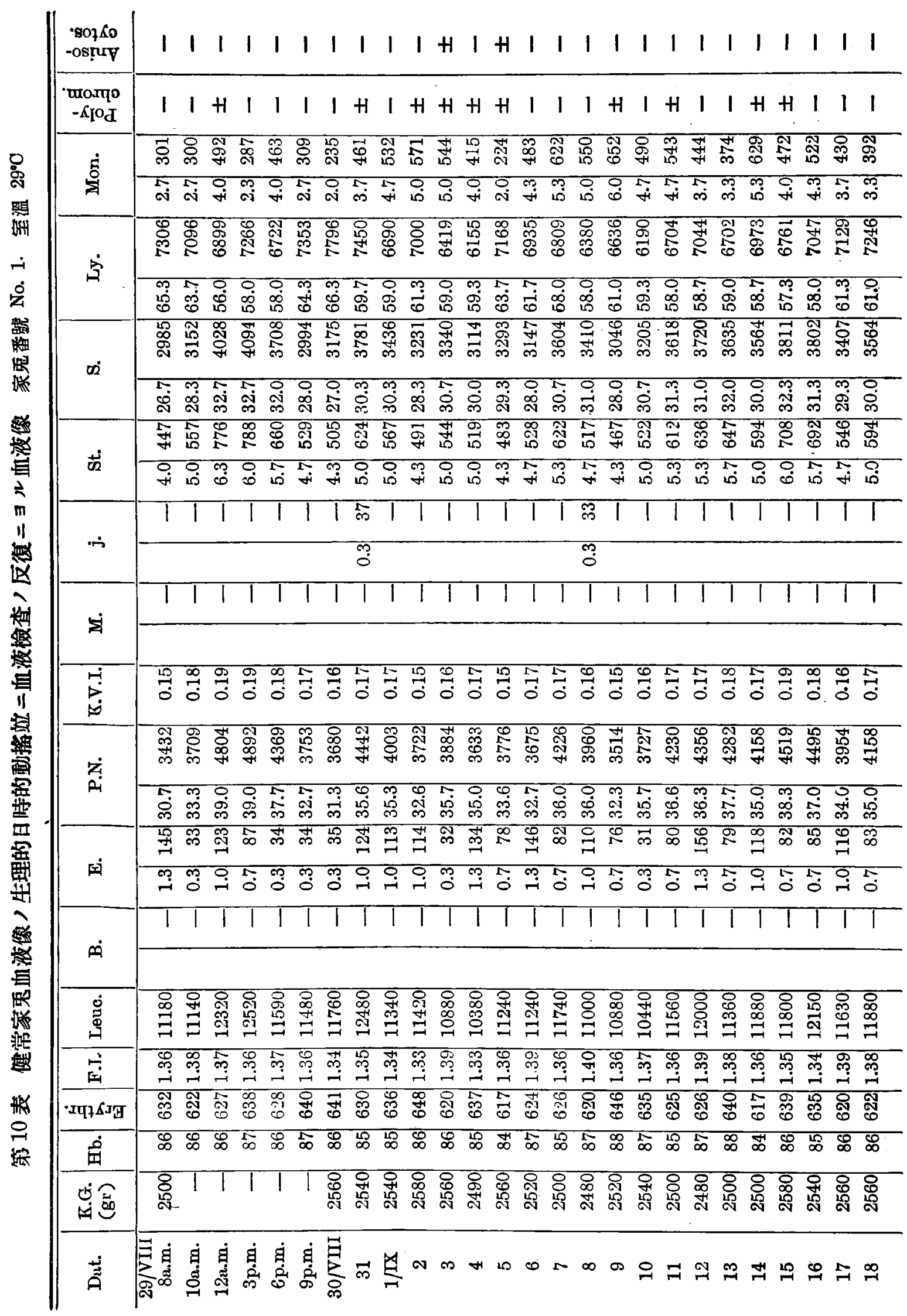




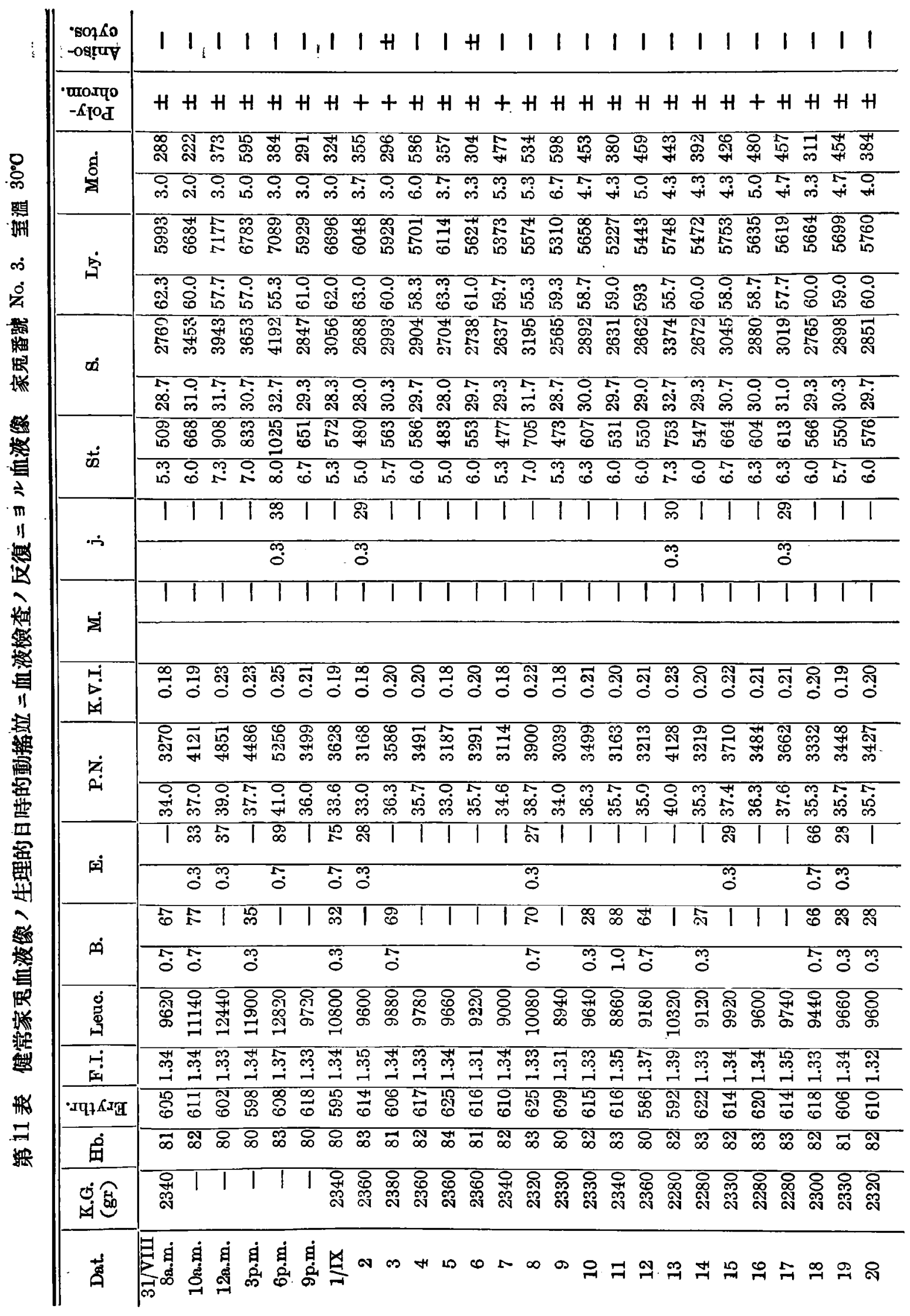




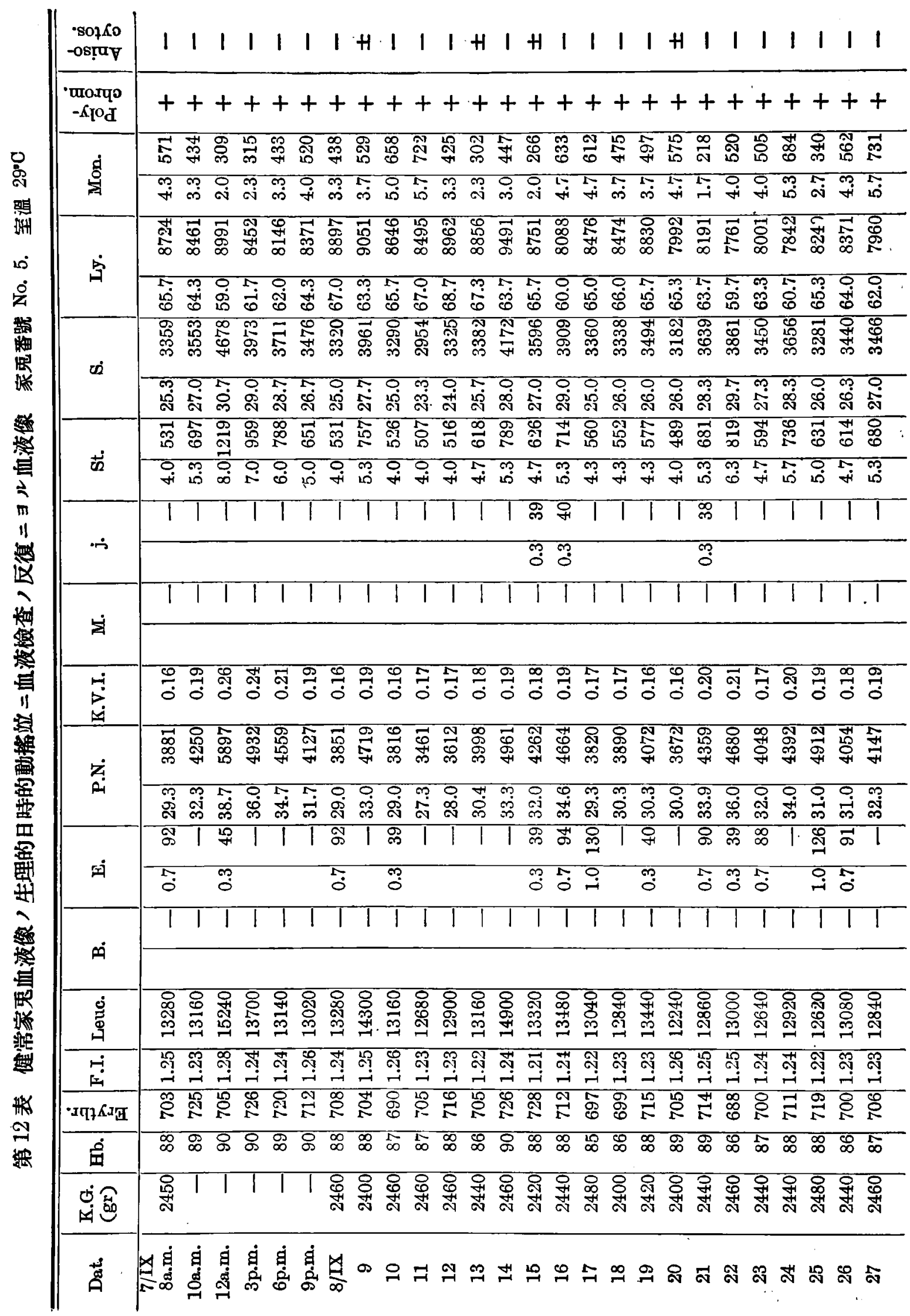




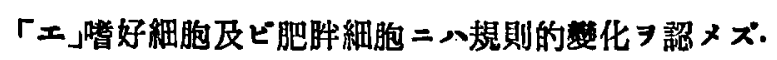

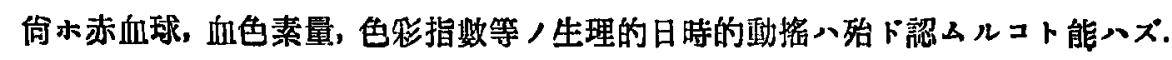

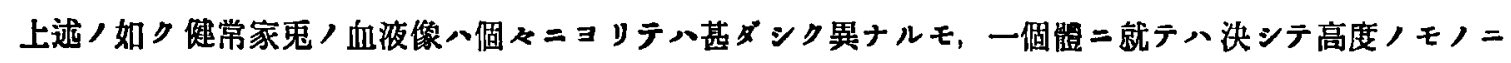
アラズシティ一個體 /生理的動播八左程大ナルモノニ非ザル事ヨ知レリ.

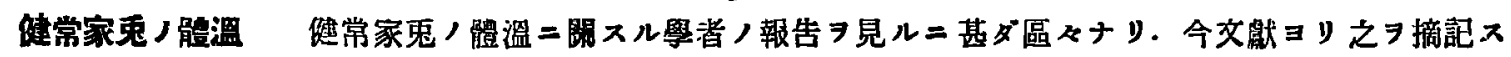

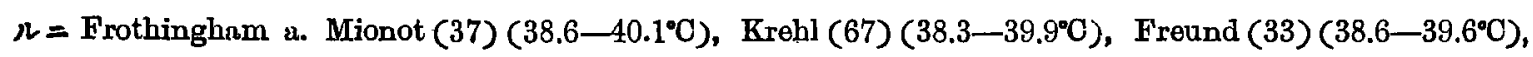

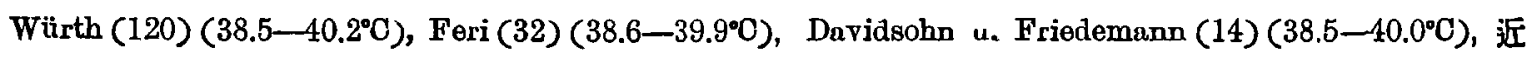
落 $(66)\left(38.6-39.9^{\circ} \mathrm{C}\right)$, 祭藤 $(151)\left(39.4-39.6^{\circ} \mathrm{C}\right)$ ，木下 $(138)\left(37.3^{2}-40^{\circ} 1^{\circ} \mathrm{C}\right)$, 阿部 $(122)\left(38.5-39.9^{\circ} \mathrm{C}\right)$,

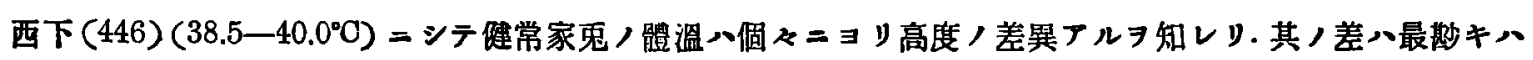

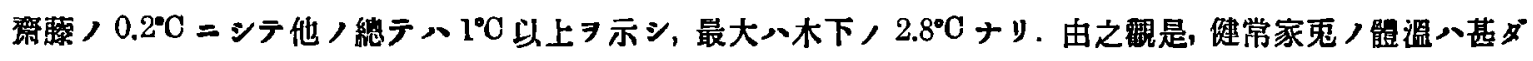

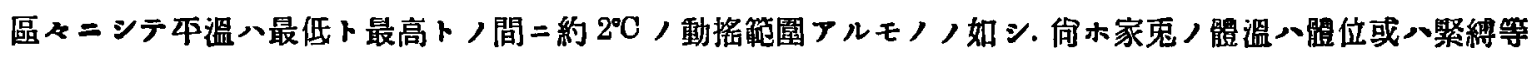

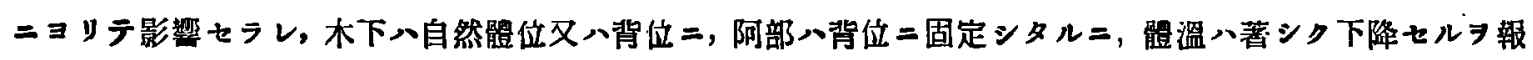

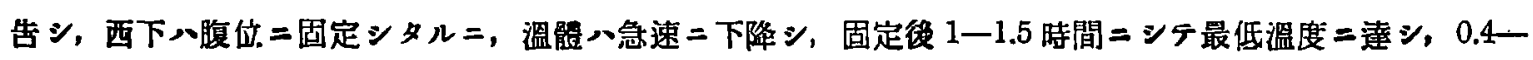
$1.0^{\circ} \mathrm{C}$ 下降セリ. 其/後徐そ二上昇スルモ4一 5 時間後少小正常時二恢復スルコトナシ. 又背位 $=$ 固定シタル 二其ノ下降度八腹位, 堒合ヨり一層强り $0.9-2.9^{\circ} \mathrm{C}$ 下降セりト言へリ.

サレバ余八特二家鬼ノ體位 =泩意シ正常體位二於テ固定スルコトナク健常家 鬼 83 匹二就厅測定セル正常時，體溫 $\ni$ 通覮スル二最低 $37.4^{\circ} \mathrm{C}$, 最高 $39.6^{\circ} \mathrm{O}=シ$ テ其ノ間 $=2.2^{\circ} \mathrm{O}$ ，差異アリ. 今之 $70.5^{\circ} \mathrm{O}$ ，差习以テ類別スル $=$ 第 13 表二示

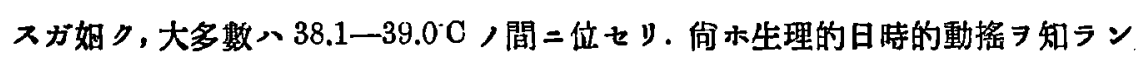
ト欲シ午前 8 時, 午前 10 時, 正午，午後 3 時，午後 6 時，午後 9 時，6回二互》 テ检温セルニ，一般二午後二於テ輕度二上昇シ，午後 3-6 時頃二最高 $习$ 示スモ

第 13 表

\begin{tabular}{|c|c|}
\hline 體溫 & 頭數 \\
\hline $\begin{array}{l}37.0-37.5^{\circ} \mathrm{C} \\
37.6-38.0^{\circ} \mathrm{C} \\
38.1-38.5^{\circ} \mathrm{C} \\
38.6-39.0^{\circ} \mathrm{C} \\
39.1-39.5^{\circ} \mathrm{C} \\
39.6-40.0^{\circ} \mathrm{C}\end{array}$ & $\begin{array}{r}3 \\
3 \\
36 \\
32 \\
8 \\
1\end{array}$ \\
\hline
\end{tabular}

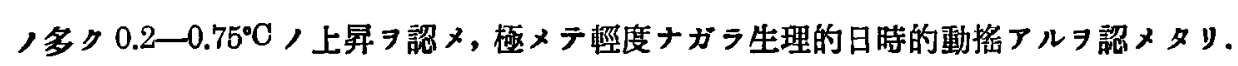

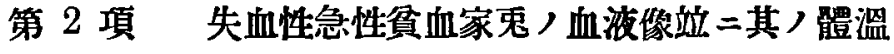

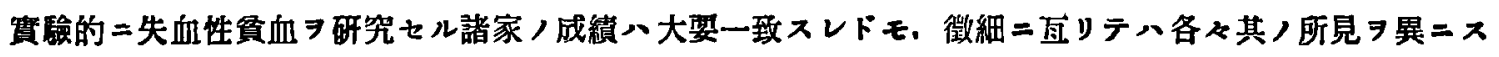

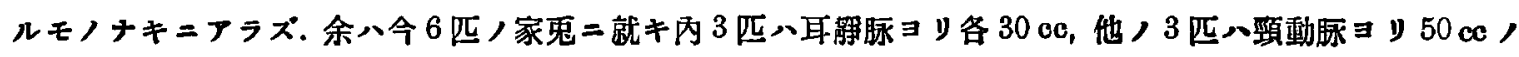

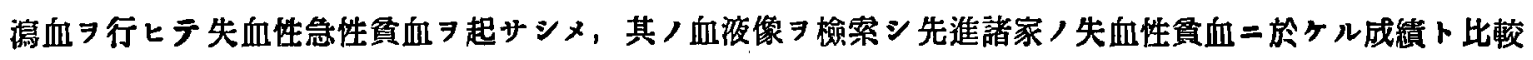
影シテ之ヨ視察セントス(第 14一第 19 表照).

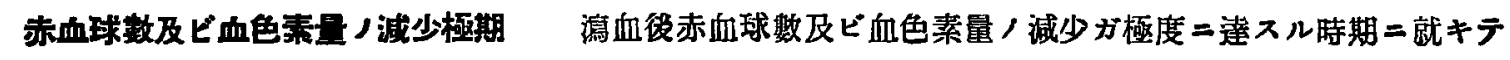

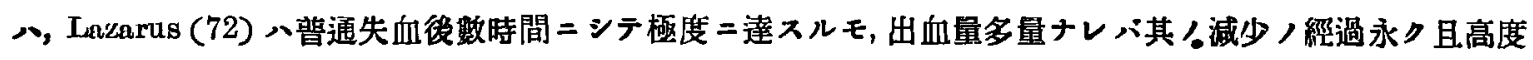

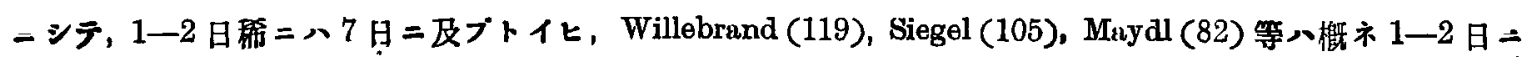

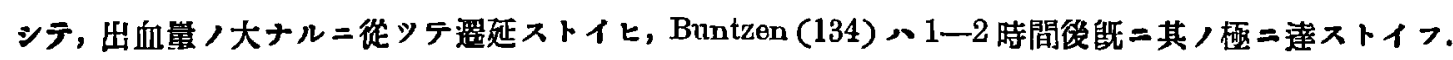

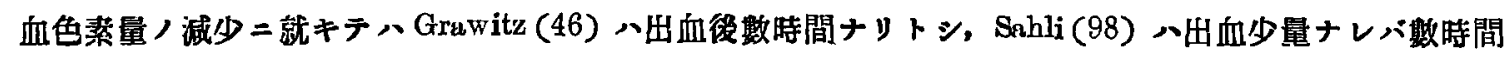
ニ過ギザドモ多量ヨナレバ第 9 日位ニシテ始メテ極度ニ達ストイフ. 次二赤血球數及ビ血色素量/減少

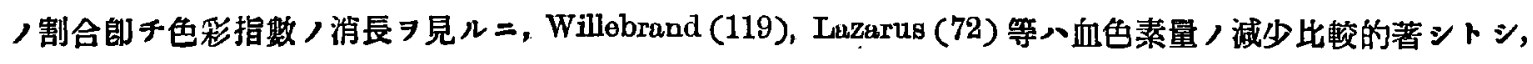
Sanli 八出血ノ初メ二八兩皆本行シテ減少ストイヒ, Hayem (50) 八兩皆，割合ガ健康時二等シキカ又心血 
色素量ガ比較的少量トナルタメ二，色彩指數、1 =留ルカヌハ稍く下降ストイヒ，Naegeli (89) 八最初八血

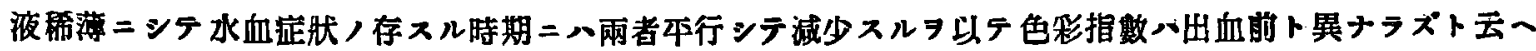

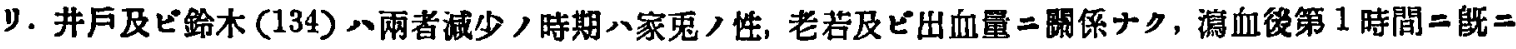
著明ニシテ其/減少ノ度八赤血球數二比シテ血色素量ノ方强キョ以テ，此時/色彩指數入健康時ノ夫レョ

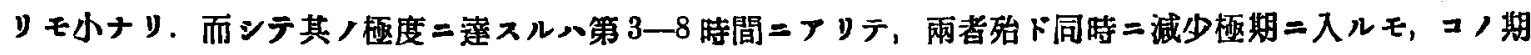
間=於テハ血色素量二比シ赤血球數 /隇少度大ニシテ, 從シテコノ時期ノ色箖指數ハ泊血第 1 時間目ノ夫

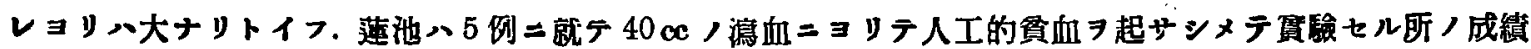

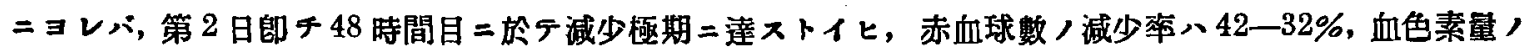
夫レハ 40-33\% =シテ，40\% 前後 7 示スモノ多》，5 例中 4 例二於厂前者二比シ後者ノ方減少，度强カリ

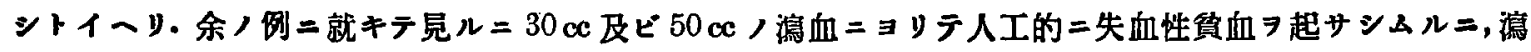

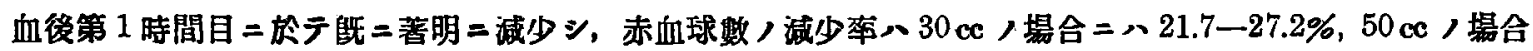

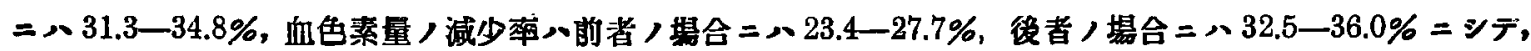
血色素量隇少/度入赤血球數ノ夫レョリモ著シク，從シテ色彩指數入渇血的ヨリ小ナリ・而シテコノ减少率

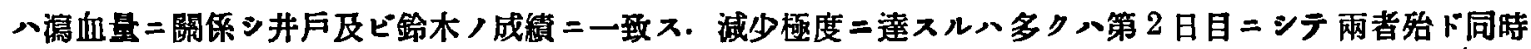

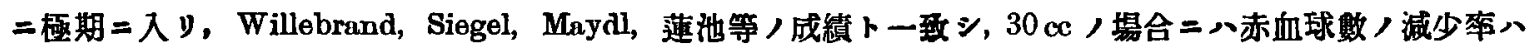

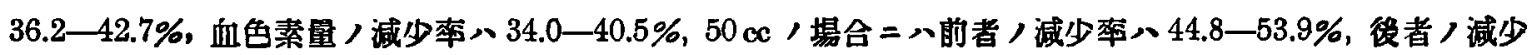

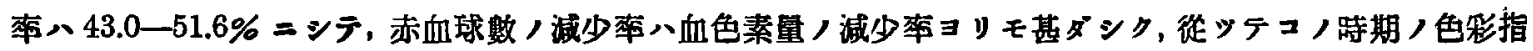

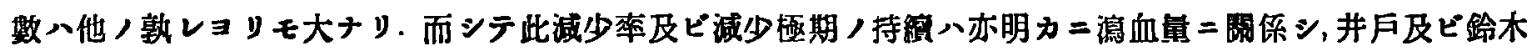

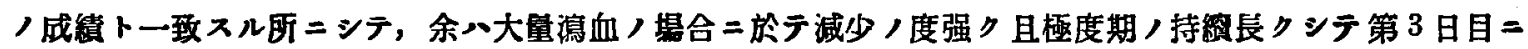
於テモ向ホ著明ナリシ 1 例 7 賽驗セり.

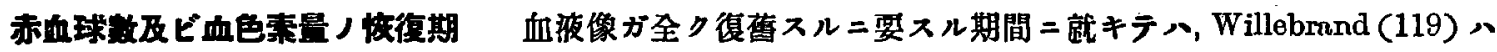
赤血球數ハ14-25 日，血色素量、14-33 日ナリトシ，Hühnerfauth (53), Lyoh (81), Buntzen (134),

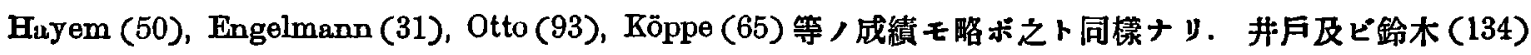

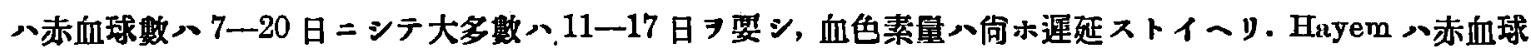

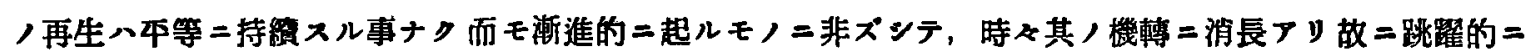
進行シ且血色素/再生八稍を運延スルタメニ; 恢復期ノ色彩指數八著シク下降スルモノンシテ,コノ現象八

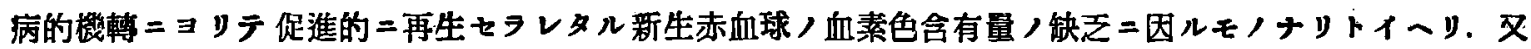
Naegeli (89), Morawitz (86), Otto u. Laache (68), Lindsay S. Milne (79), Sahli (98) 等八皆血色素量，恢 復の赤血球ヨリモ僬延スルョ認メタレドモ, 其ノ再生機轉ニ就テハ各見解

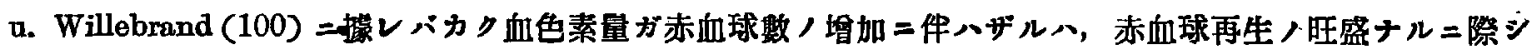

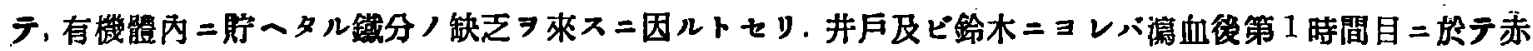

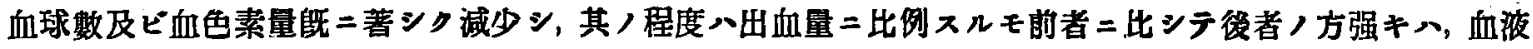
ガ組織夜及ビ淋巴液 ノ侵入二因ッテ希釋セラルルノミナラズ，幼若赤血球ノ混入スルニ因ッテ色彩指數 下降

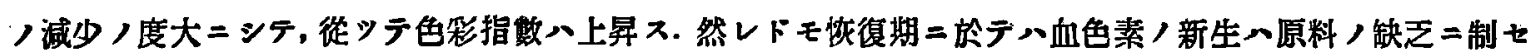

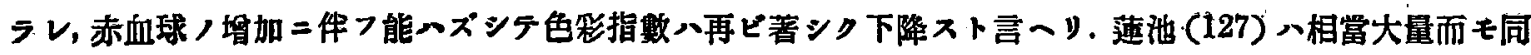




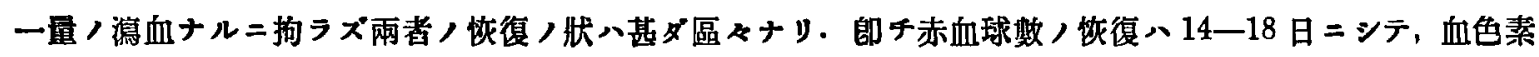

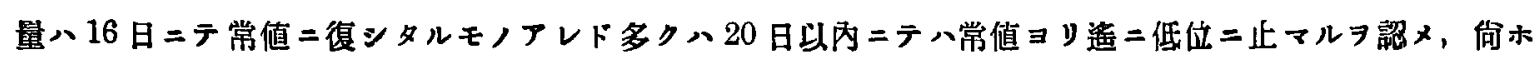

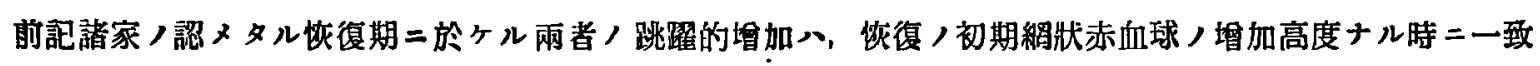
シテ多キヨ見タリト言ーリ.

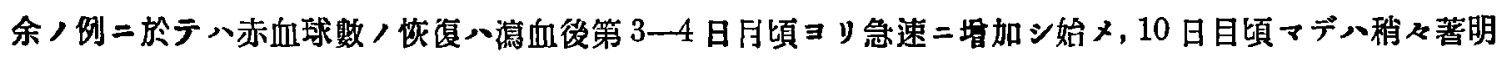

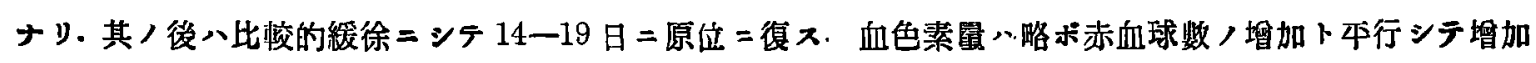

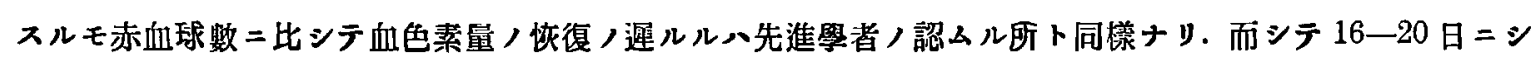

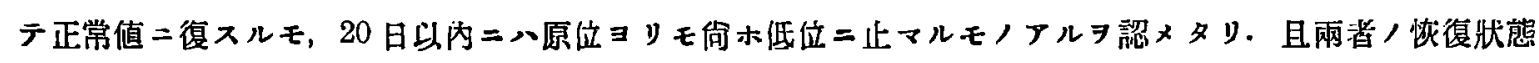

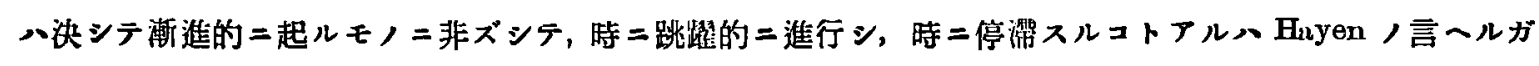
如シ.

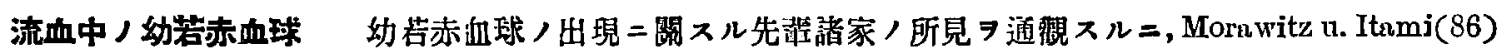

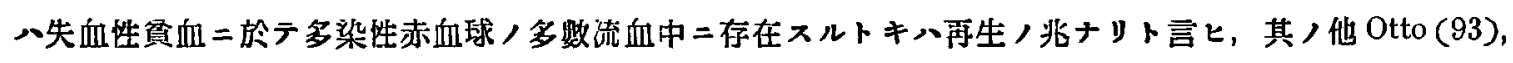
Laarche (68), Lazarus (72，Lindsay (79)，Willebruhd (119) 等多数 /學者八總べ赤血球再生現象，盛ナ ル時期二八, 該赤血球，多數流血中二出現スルコトニ就テハ全ク一致セリ. 多染性赤血球，出現/時期二關

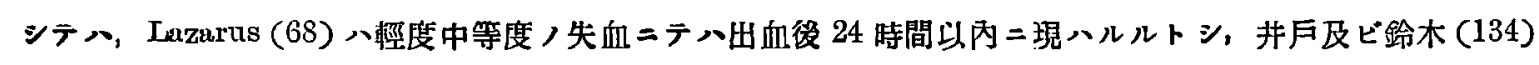

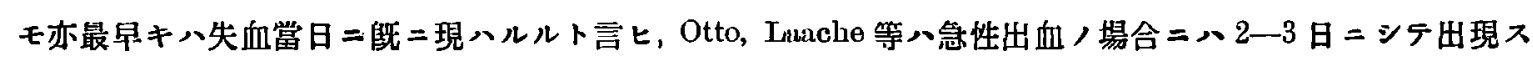
トシ，䔎池 (127) 八第2日目ヨリ出現增加スルモノ多シト言ーリ.

照基性顆粒赤血球二關シテハ一般二中毒性筫血ノ際ニ多ク現ハルルモノニシテ, Grawitz $(42,47)$ 八該赤

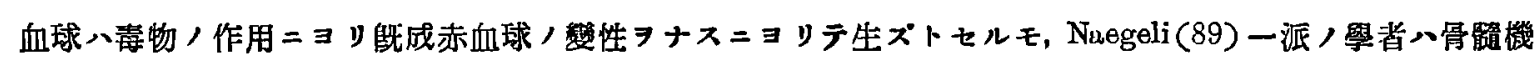

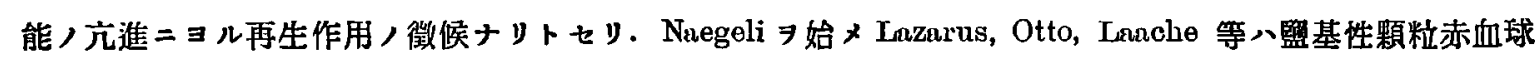
、失血後 頚血ニ八出現スルコト少ナシトセルモ，Lindsay s. Milne八失血後 3 日目二八既二出現シ而シ

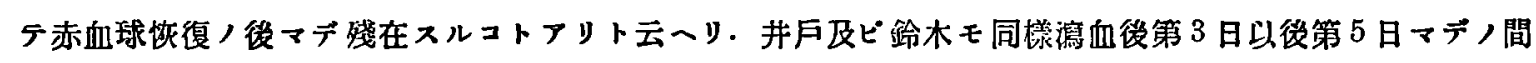
二出現ストセリ.

有核赤血球二就キテ八 Rieder (95)，Lindsay S. Milne(79), Otto (93)，Larache (68) 等八源血後 2-3 日

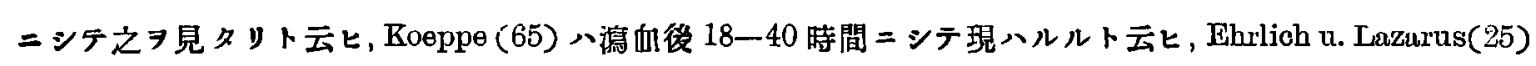
、急性失血後二八24時間以內二現ヘレズトシ,Grawitz (45), Willebrand (119) 等八澺血後第 1 日二出現 見タリト云フモ，井戶及ビ鈴木 (134)八最早キモノニテハ35 時間, 日數ニシテハ第 2 日目二出兒ストシ，掘 キ八第 5 日目二出現シタルモハフリト云ーリ. 莲池 (127) 八第2日ニ見タルモノフレド，他八總ベテ其ノ出 現尹見ルハ第 4 日目ナリトセリ. 而シテ Nuegeli (89), Türr (111), Rieler (95) 等 N Megaloblasten 7 見タ リト云フモ, Grawitz (45)，Blumenthal (7)，井F及ビ鈴木 (134)，蓮他 (127) 等ハ夫トシテ Normoblastn

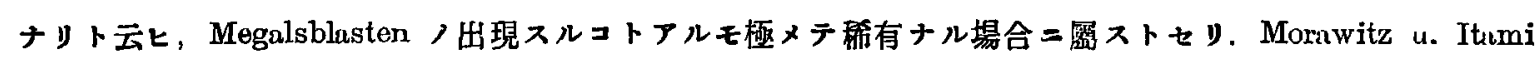
(86) 八再生作用ノ旺盛ナル時期ニモ之ヨ缺クコトナリト記セり。

Buyem (50) 一派，學者八新生赤血球八小型ナリトスルモ, Schuman u. Rosenqvist (99), Willebrand

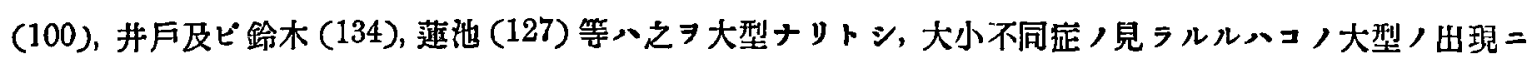
ヨルモノナリトセリ.

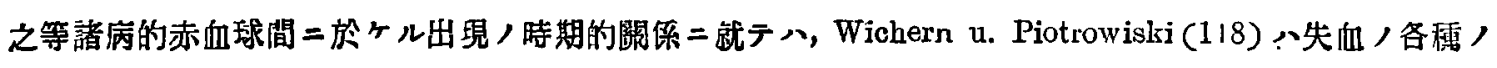




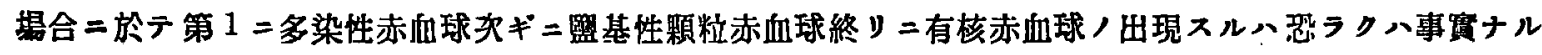
ベシト云ヒ，井戶及ビ哙木ハ多染性赤血球最早ク出現シ，之ト殆ド同時二大小不同症著明トナリ，次デ有核 赤血球及ビ監基性顆粒赤血球八殆ト同時二出現ストシ，「失血性筫血二八缺如ス」ト唱フル一部學者ノ珫八 當习得タルモノニ非ズトセリ。

余ノ成縝二就テ見ル二，家兔二於テハ健康時二於テモ多少，多染性赤血球，循血中二存在スルハ先翡， 既二認ムル所ニシテ, 余モ亦之ヨ認メタリ.多染性赤血球入失血後最早キハ7一10時間後ニ琴ハルルモノナ

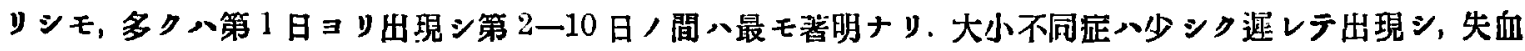
後第 2-9 日間八著明ナリ.

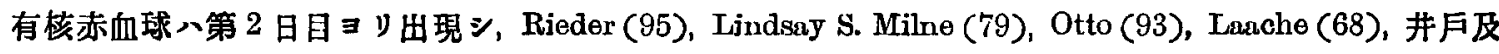

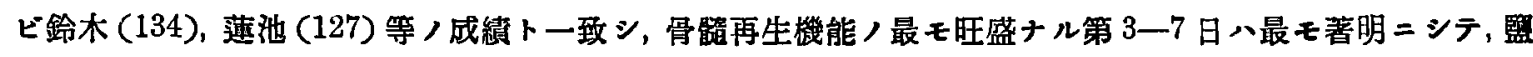
基性顆粒赤血球モ㱠ド之ト同時二或ハ少シク遳レテ出現シ，第 4 日一6 日頃ニ八最モ著明ナルョ認メタリ.

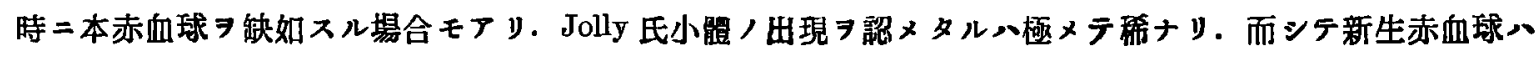
常ニ大型ニシテ, Schuumnn, Rosenqvist, Willebrund, 井戶及ビ踰木，莲他等 /所見ト一致シ，大小不同症

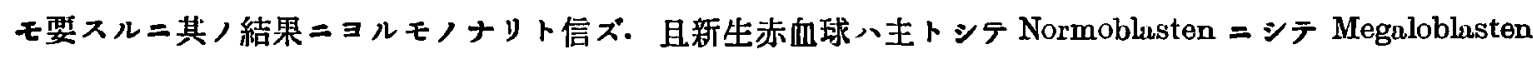
ヨ認メズ．余モ亦Grawitz，Blumenthul，井戶及ビ踰木，莲他等 /說ニ賀同スルモノナリ．向ホ之等病的赤 血球間二於ヶル出現時期二就テハ, 余八第 1 二多染性赤血球，出現习認メ，之ト殆ド同時二大小不同㱏現八

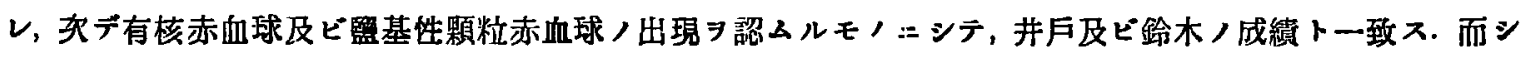

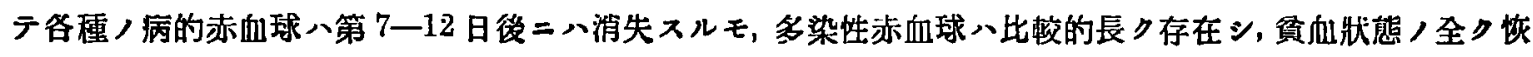
復セル後マデモ殘存スルコトアリ。

白血球失血性急性貧血ノ際二八白血球八殆ド常二增加スルモ，其／期間二就テハ多少ノ差アルカ如 シ. 即チLyon (81) 八渇血後 8-24 時間 =增加シ，3-5 日間增加大ナル時八 8 日間以上持總ストシ Arte-

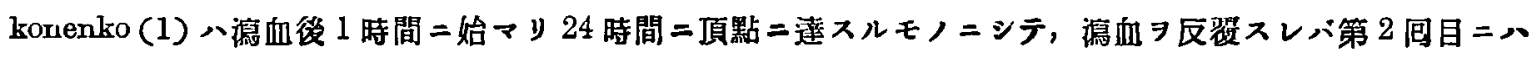

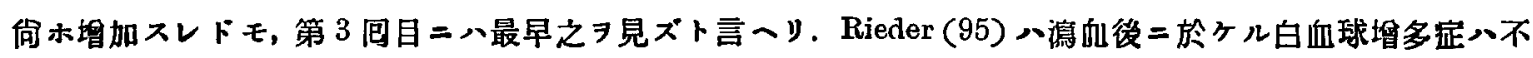
定ニシテ, 動物ニアリテハ㵂血後 1 時間二起ルモ, 其ノ程度及ビ頂點二達スル時期ハ甚ダシク不定ナリトセ

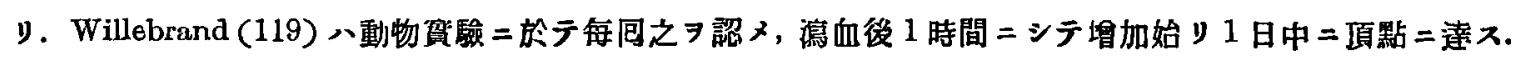

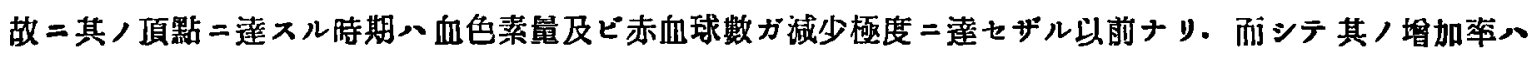

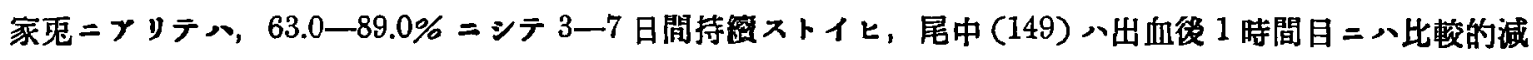

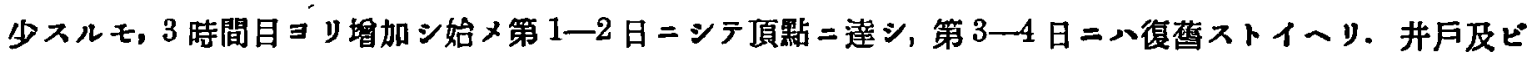

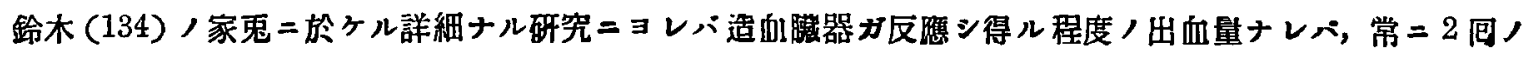

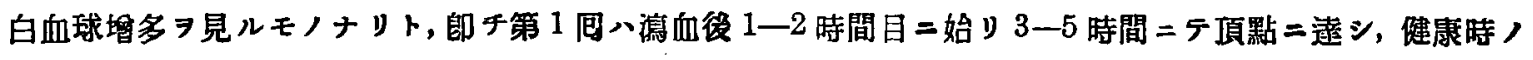

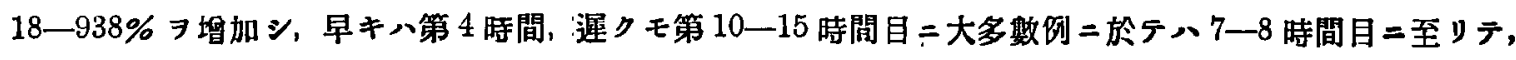
一旦消失スルカヌ八甚ダシク減少ス. 而シテ演血後第 $21-52$ 時間目二至リテ大多欺例二於テ八 $30-45$ 時

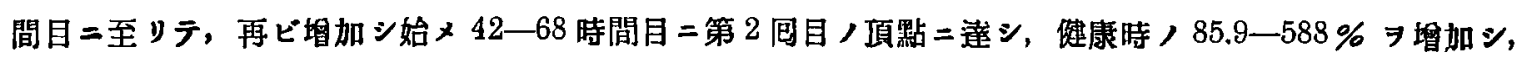

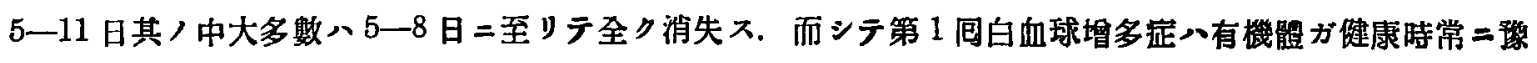

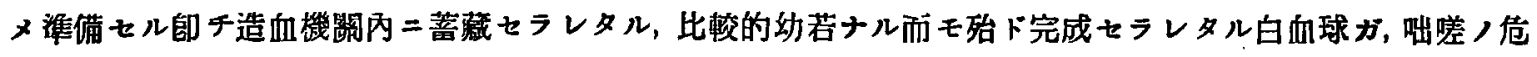

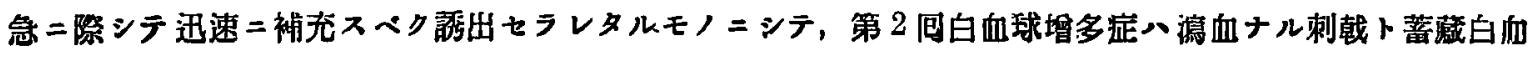


球ノ突然ノ誘出ナル刺载トニヨリテ，直接二造血機能シ六進セシメ斯クシテ促進的二新生セラレタル細胞 カ，一定時間ノ後二血管內二覆現剒加セル結果ナリトセリ。

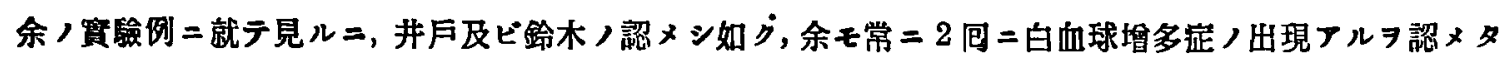

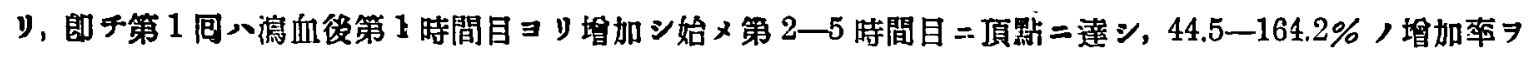
示ス. 爾唚ヘ一旦減少スルモ原数二復スルコトナク，第 1-2 日目二再ビ增加シテ最高二道シ, 78.6-238.7\%

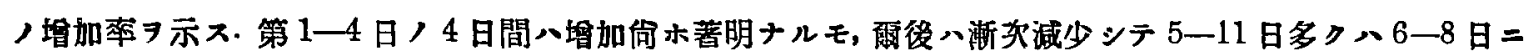

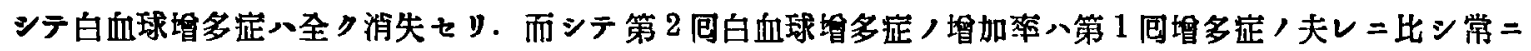

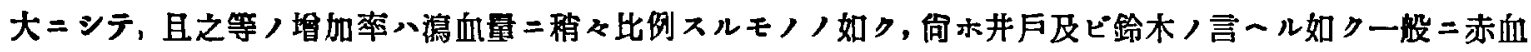

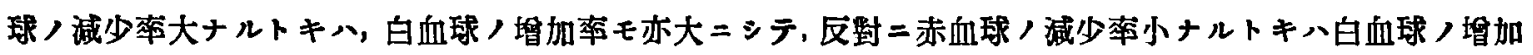
率モ柰小ナルガ如シ.

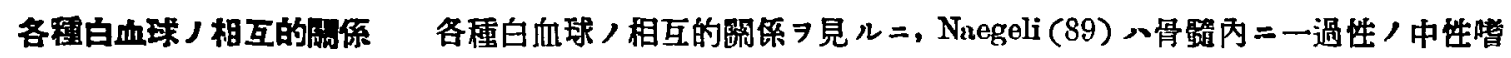
好多核細胞，增加 7 認x，Ehrlich (25)，Morawitz (87)，Hühnerfanth (53)，Lyon (81)，尾中 (149)，井户

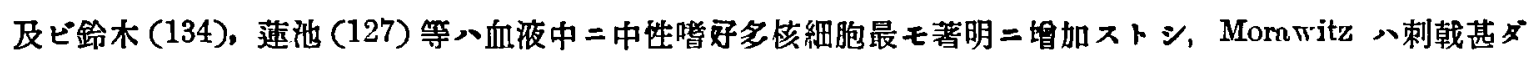

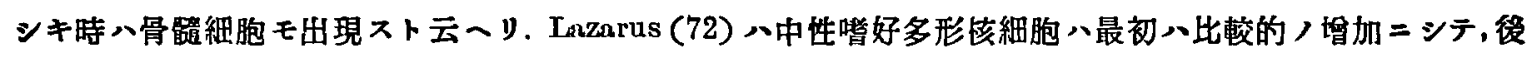

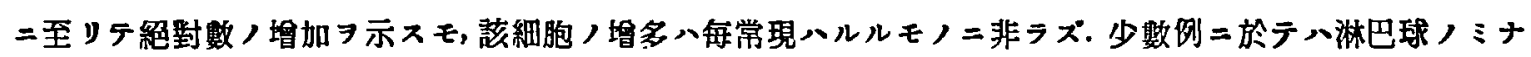
リシコトフリトシ、 Ehrlich 八㑣巴球ノ赗加八稀二見ル所ナリトセリ. Blumenthal u. Morawitz (7)八淋巴 球八增加スル事ナシトイヒ，Willebrnnd (118)，Sahli (98) 八中性嘴好細胞卜共二淋巴球モ多少增加スト云

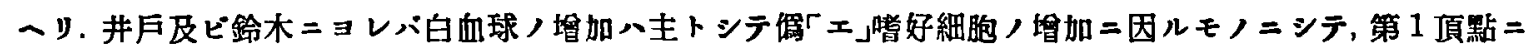

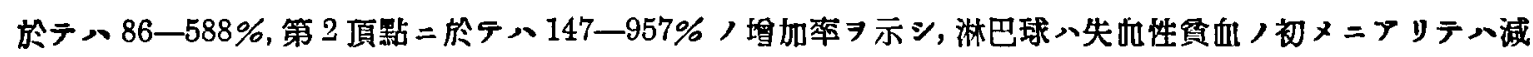

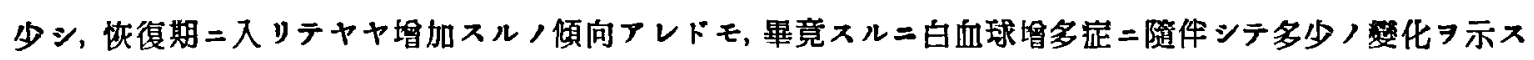

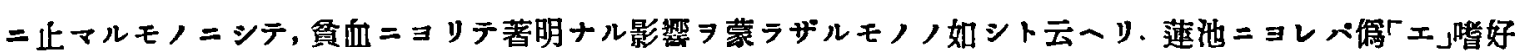

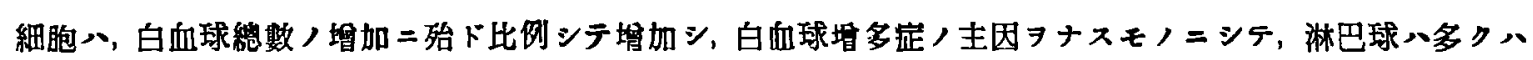

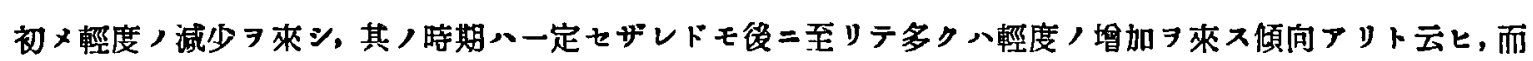
モ其ノ多ク八倌「エ」嘴好細胞ノ減ズル時期二一致セルガ如シトセり。

單核細胞及ビ移行型、Zangemeister (121)，井戶ビ鈴木 (134), 莲他 (127) $=\boldsymbol{3} ル=$ 常 $=$ 高度 增加 7 示 シ，其ノ增加率ョリ云ーバ各種白血球細胞中，最高位ニフリト云ーリ.

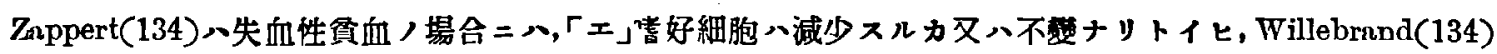

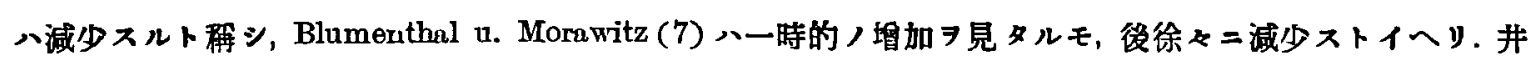

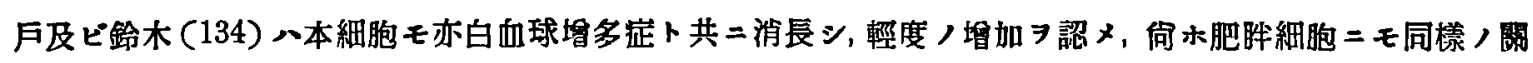

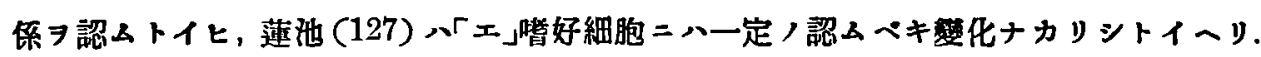

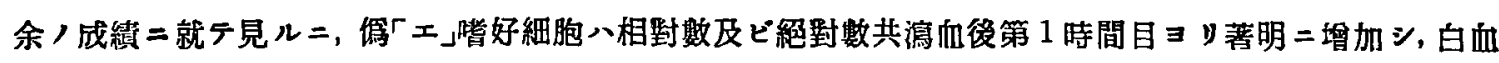

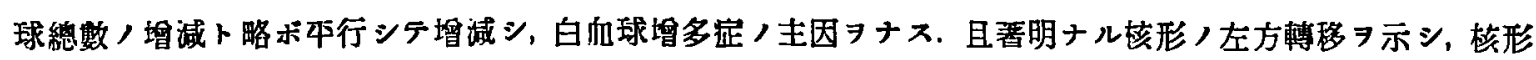

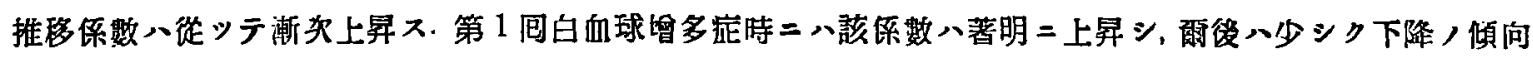
ヨ有スルモ，第 2 回白血球增多证二一致シテ再ビ甚がシク上昇シテ最高二達ス。後者，上昇卒八前者ノ夫レ

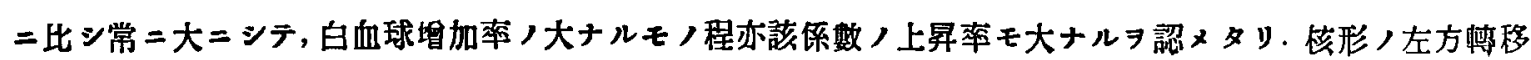




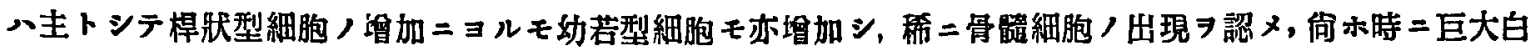

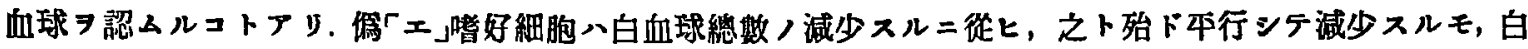

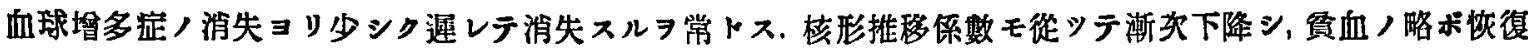

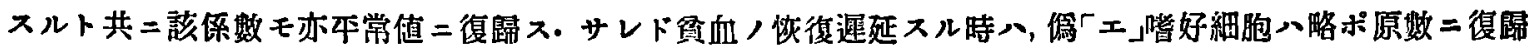

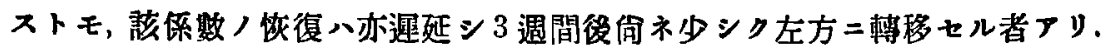

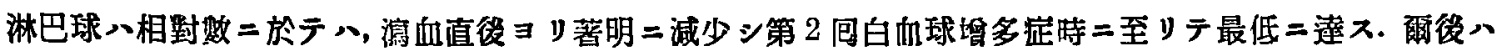

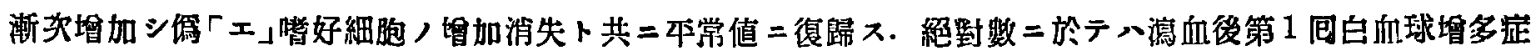

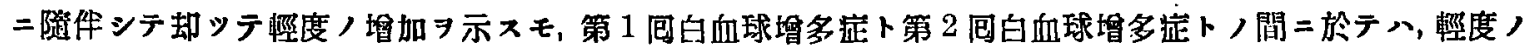

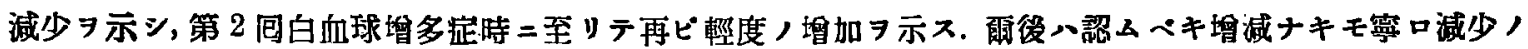
傾向ヨ有シ，一部先翡，言へル如ク，淋巴球ミガ增加スルガ如キ事八余，賽驗例＝於ケハ全ク認ムルコト

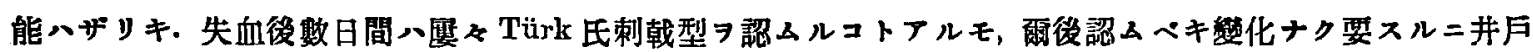

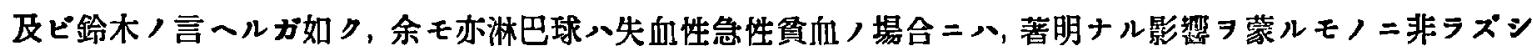
テ白血球繶數ノ增淢二隨件シテ多少，整化

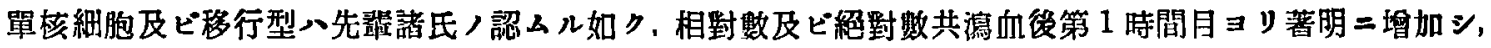
第 2 回白血球增多定時二於テ最高 $シ$ 示シ, 爾後約 1 䓢間八向木著明ナリ. 而シテ全經過中相對数及ビ絕對數 共過多ノ爿態 7 持紸スルモノ多シ.

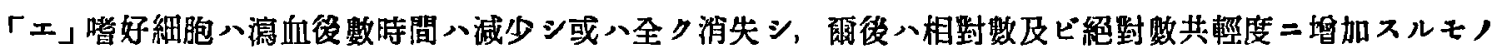
アルモ,多クハ全經過中著明ナル增減ナキモノ/如シ.

肥胖細胞ニハー定ノ認ムベキ裂化ナシ.

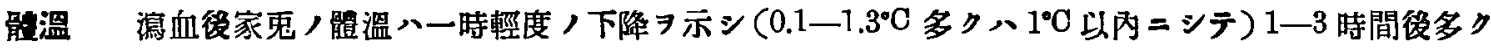

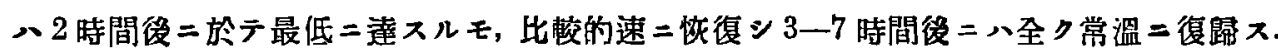

第 3 項 血液檢查，区復二因ル健常家鬼，血液像

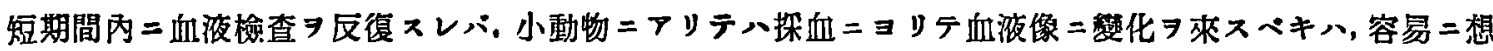

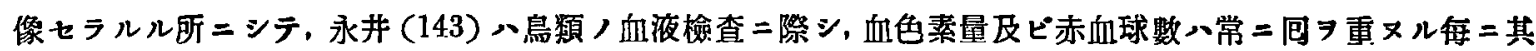

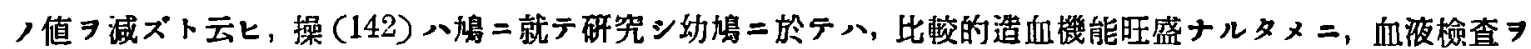

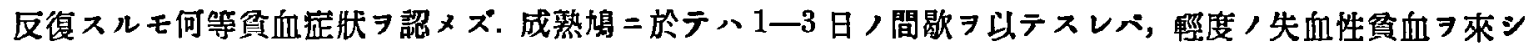

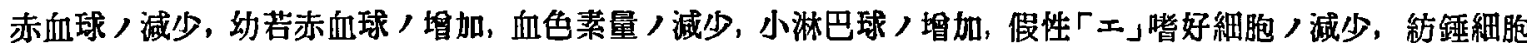

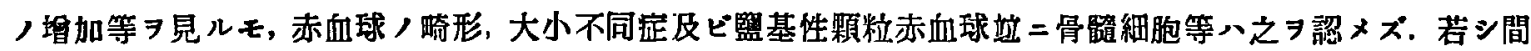
歇 4 日以上ナル場合二八筫血应狀明カナラズト，故二小動物殊二其／成熟期二於テ血液／鉒抹標本，製作

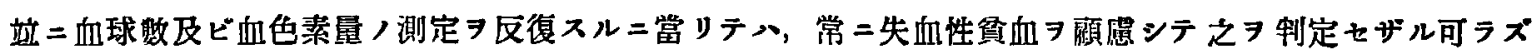
ト言へリ.

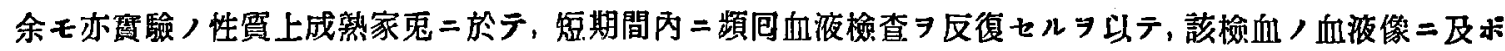

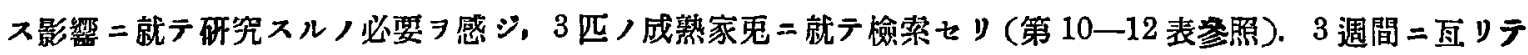

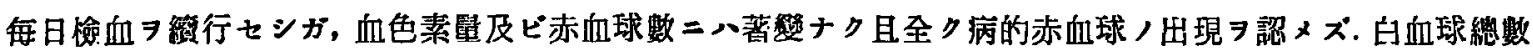

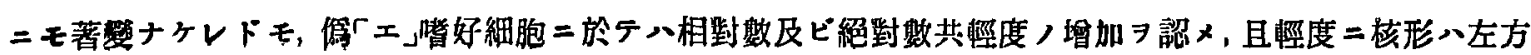




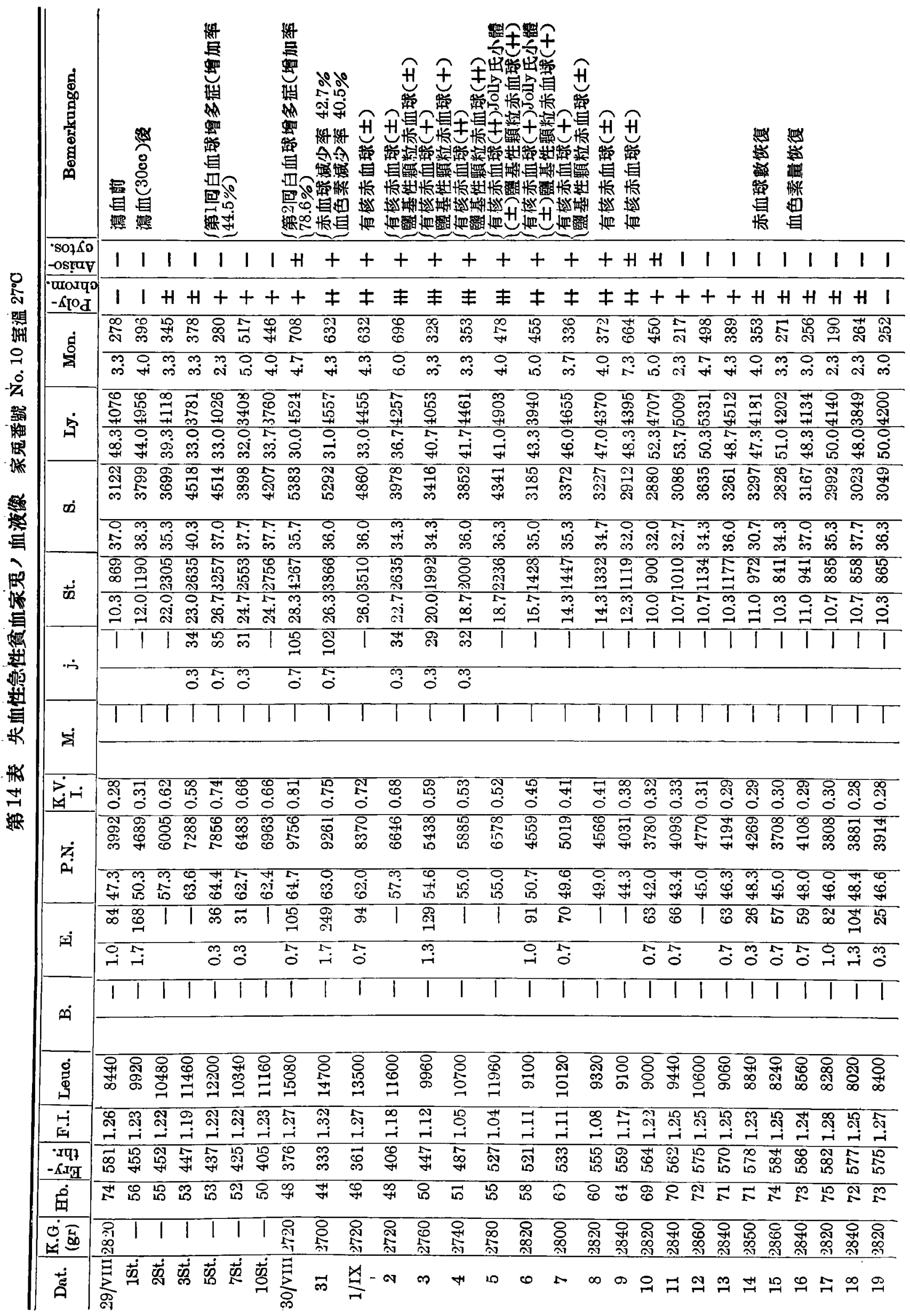




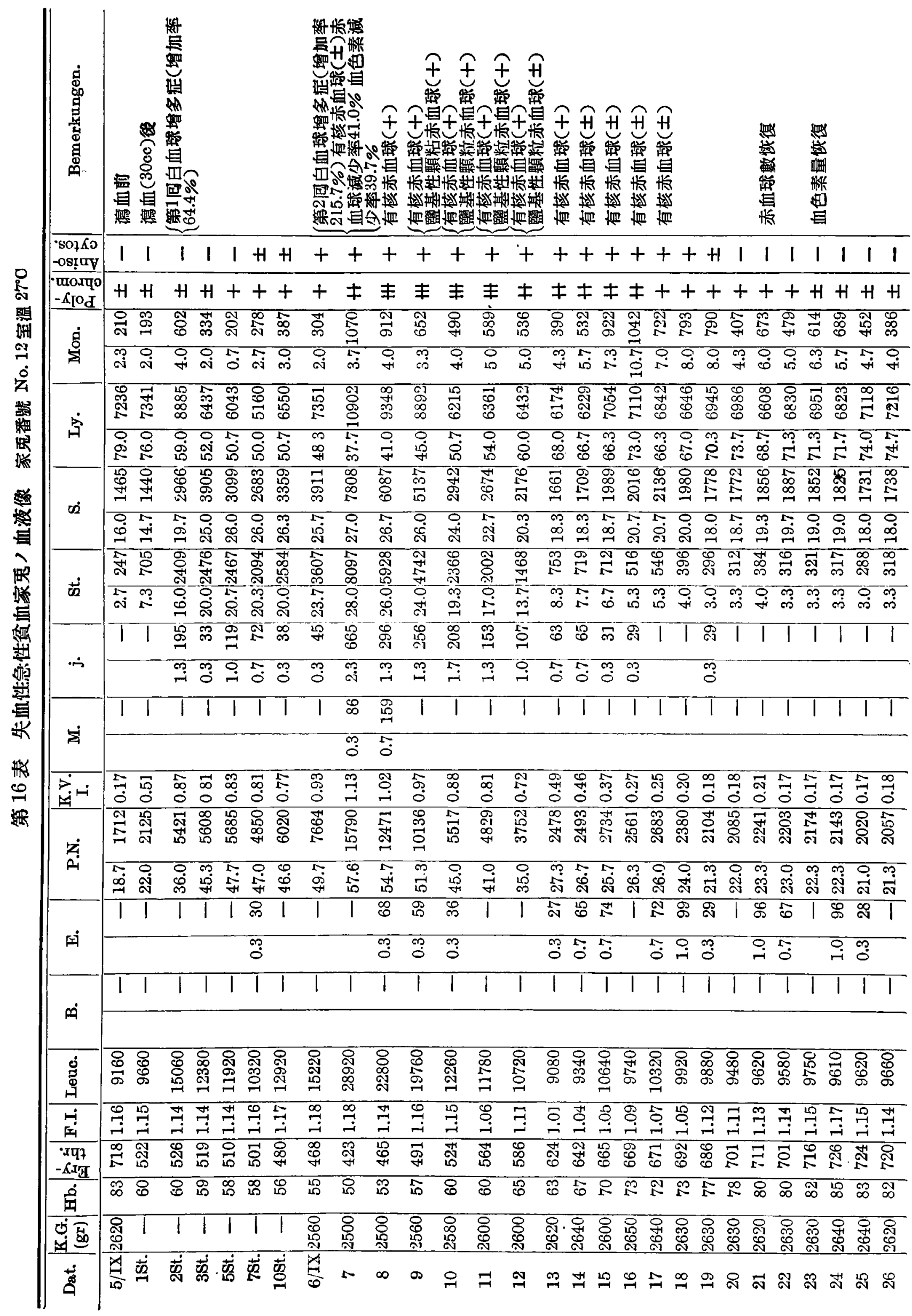




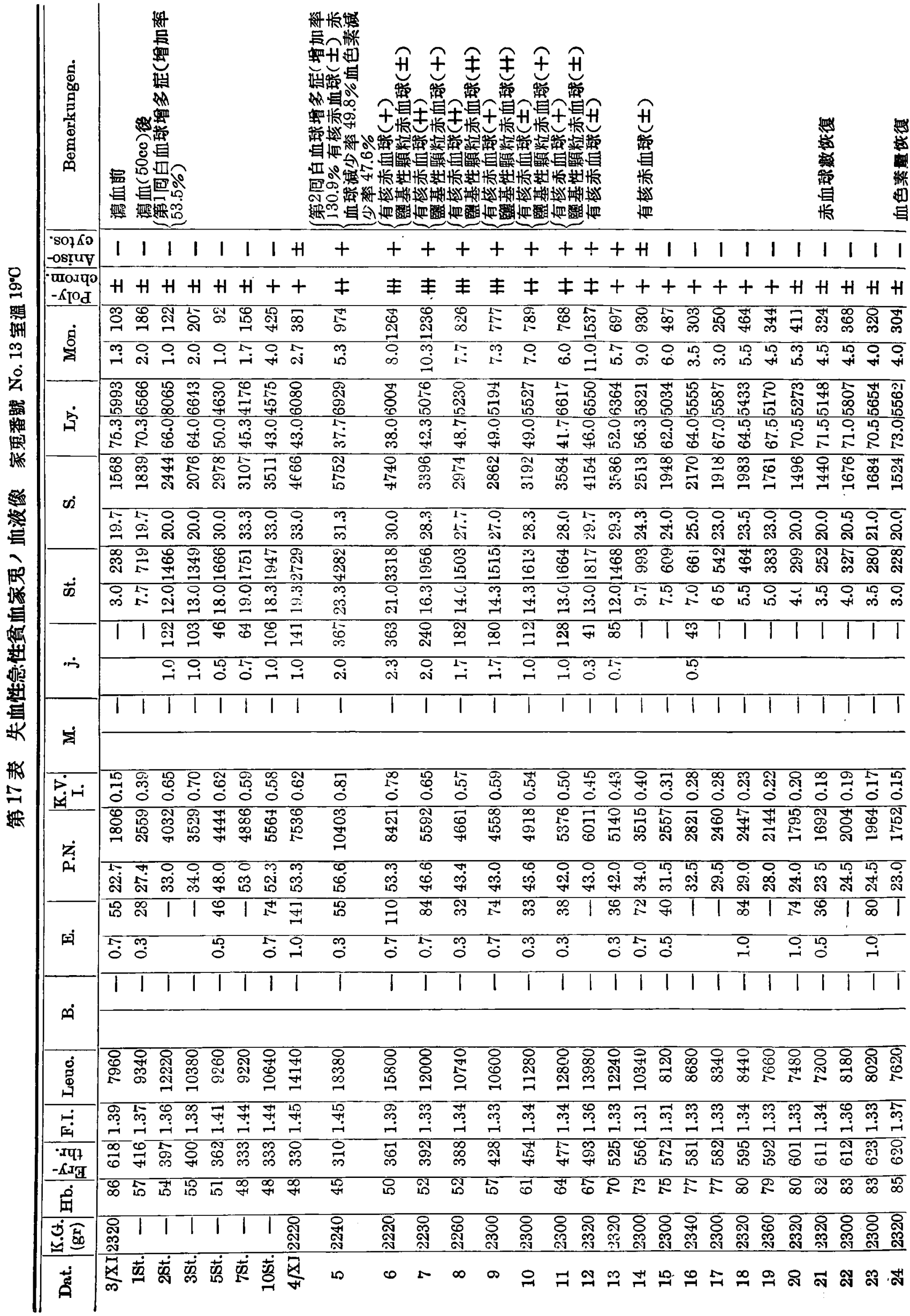




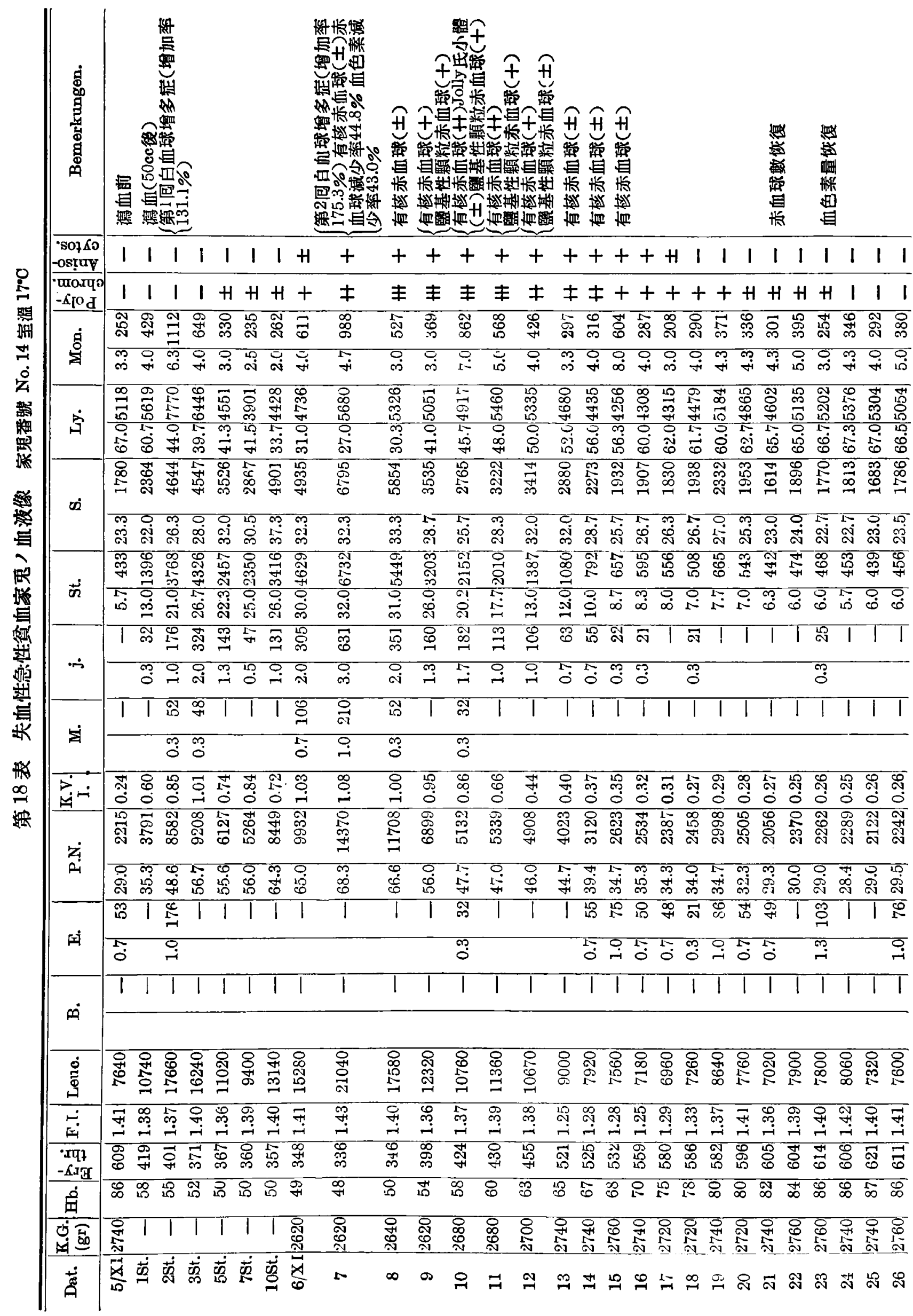




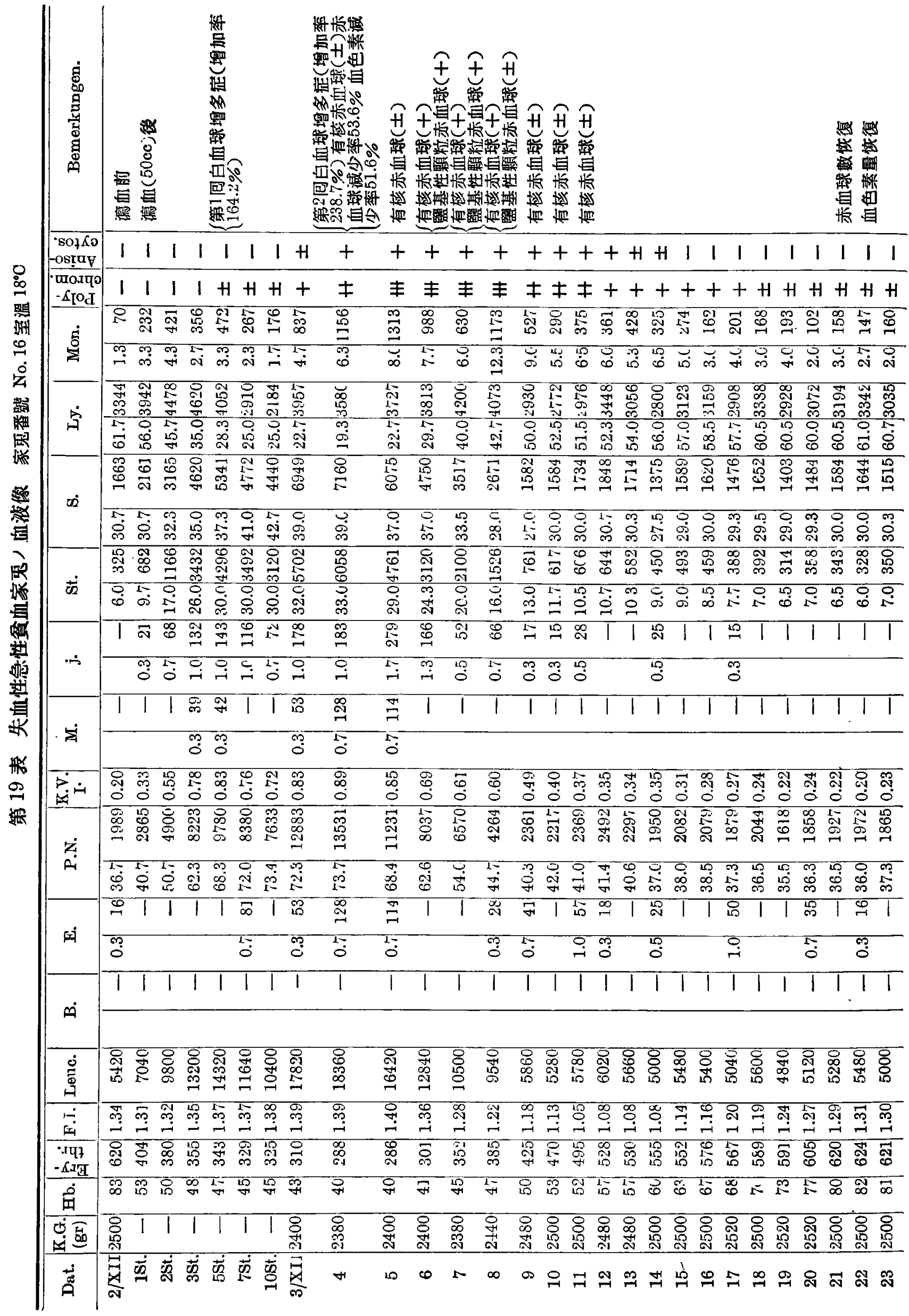




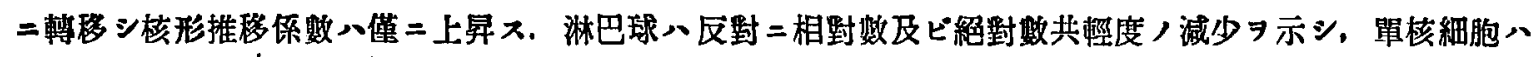

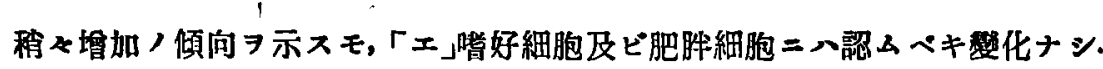

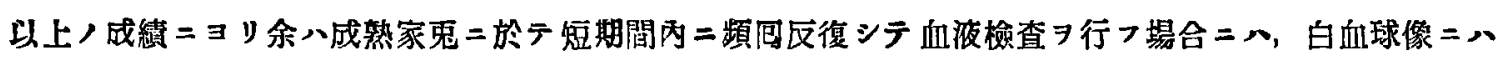

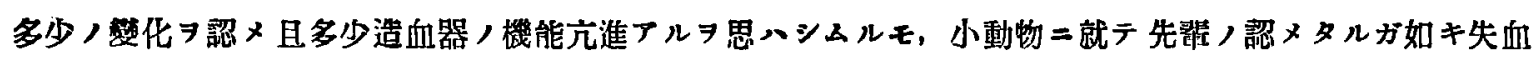

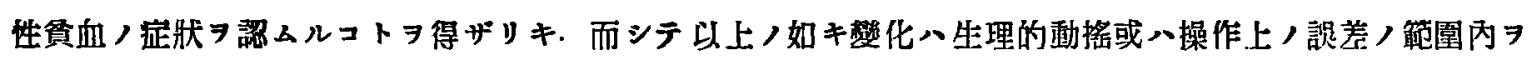

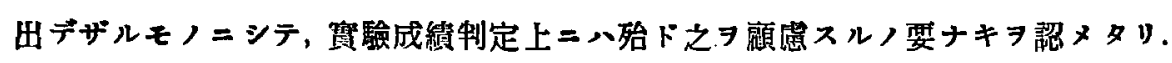

第 4 項夏季及ビ冬季二於ヶル健常家鬼，血液像及ビ體溫

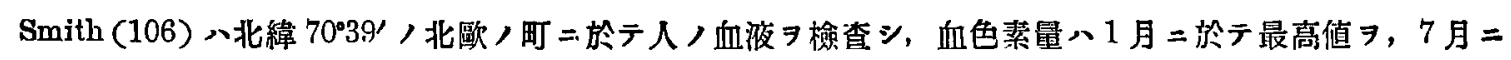

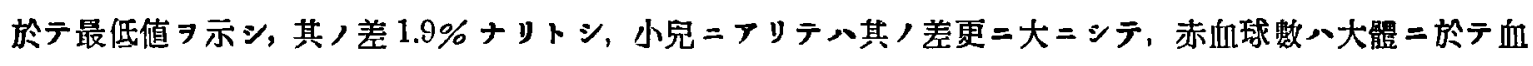

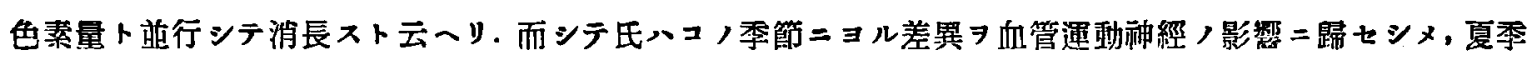

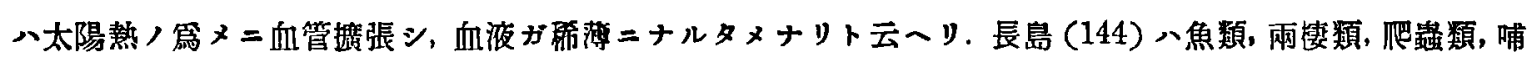

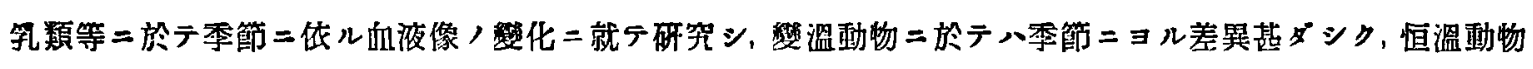

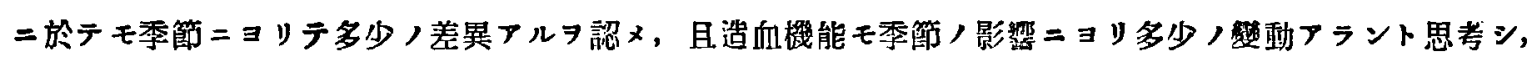

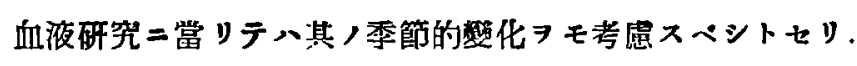

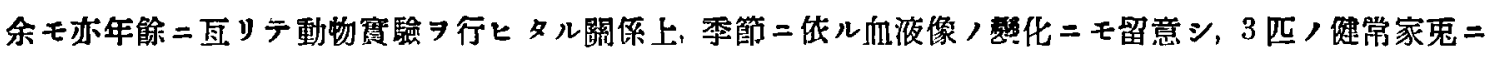

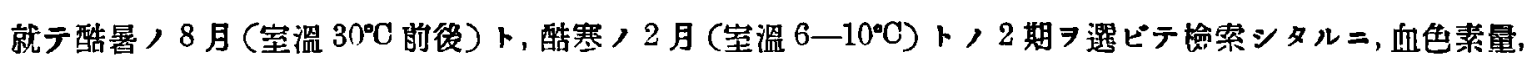

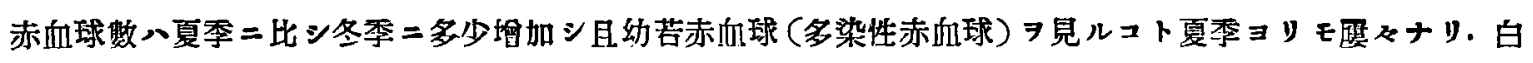

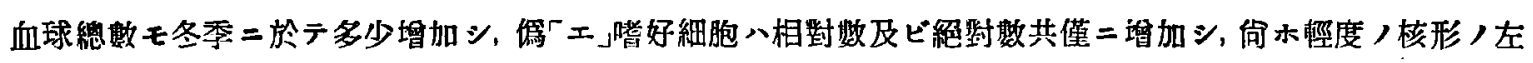

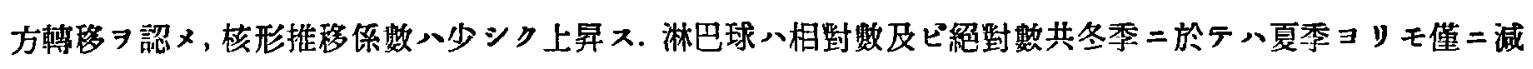

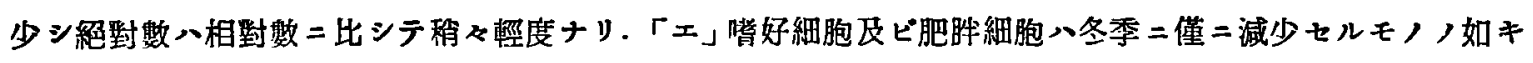

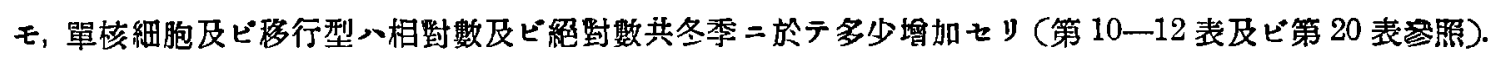

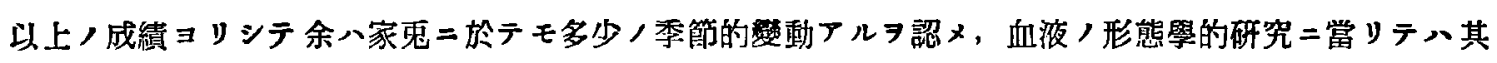

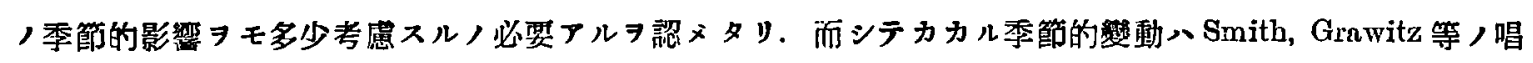

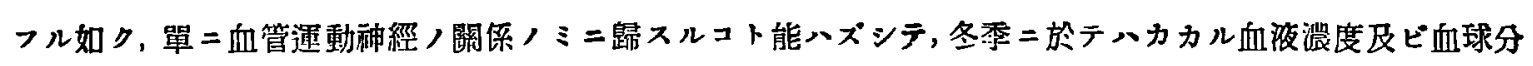

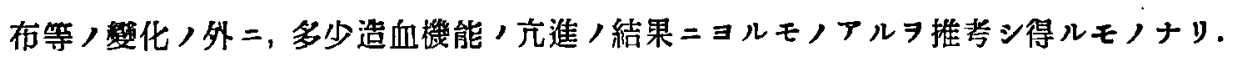

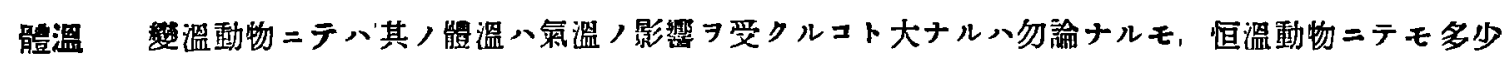

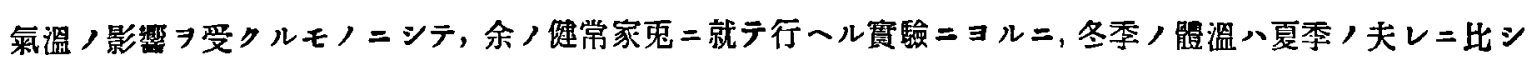
テ $0.5-1.0^{\circ} \mathrm{C}$ 低キヨ認メタリ.

第 2 節 直接輸血二ヨル失血性急性貧血家兔， 血液像, 變化立絧溫

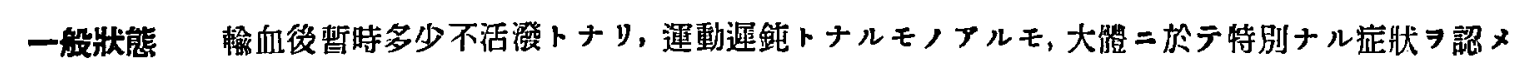
x.

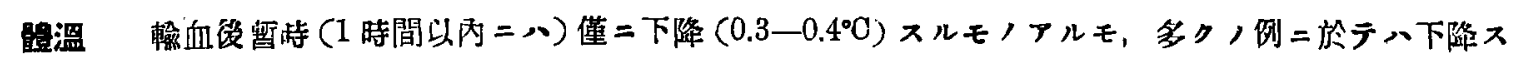

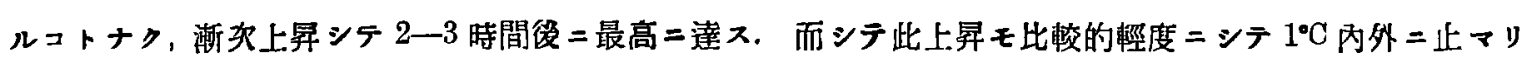

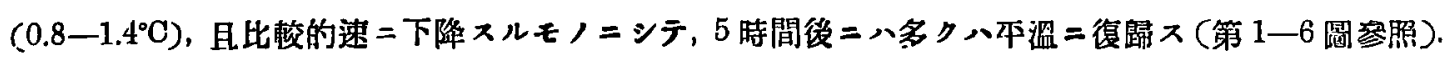



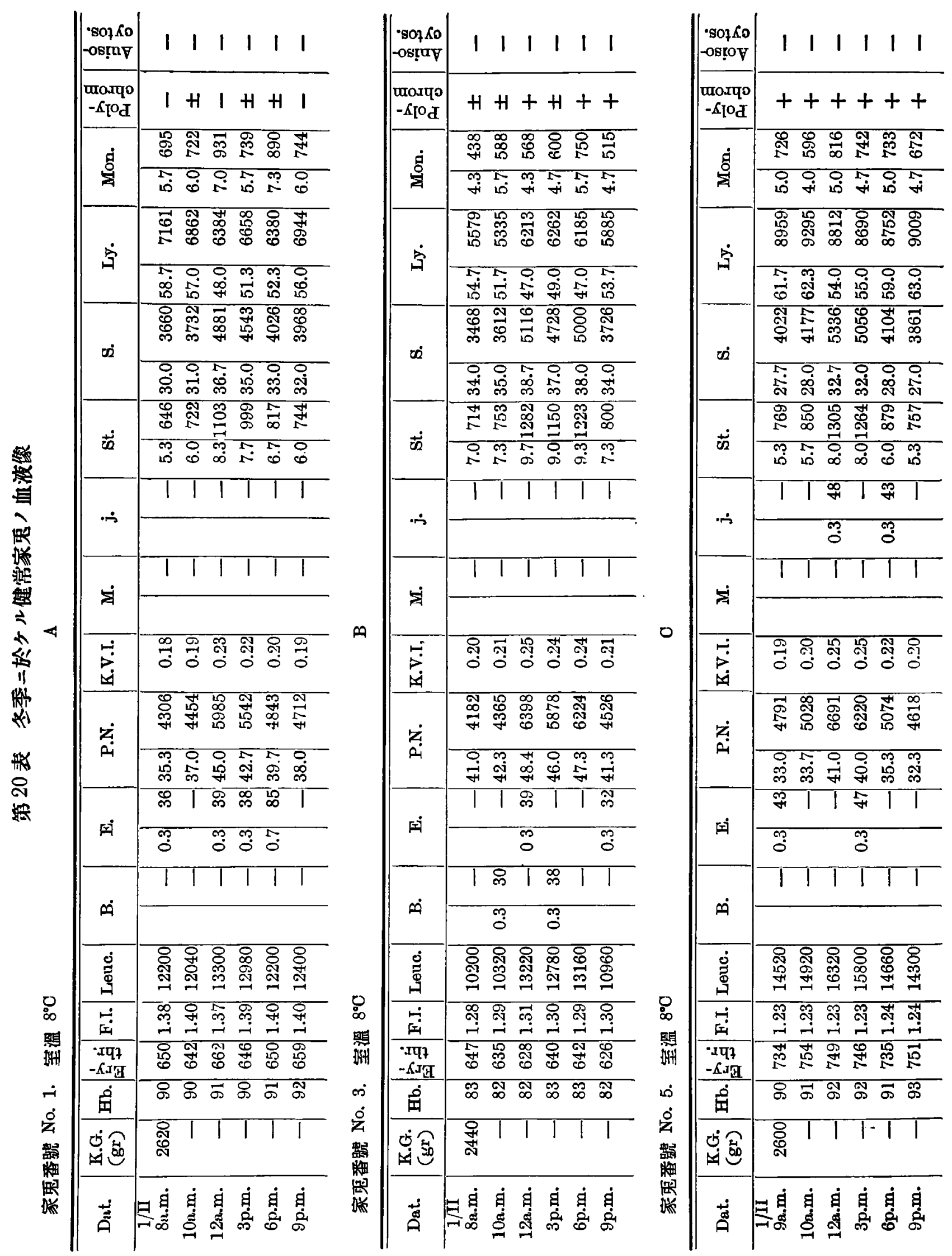
赤血球 赤血球數、榆血直後既 $=20.4-31.5 \%$ (91-143 萬)，增加 7 示シ，其ノ後 4一5 日間八增加最

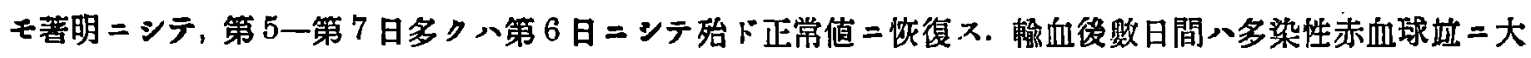

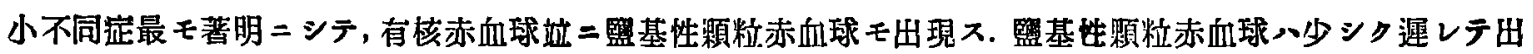
現シ時ニ認メザル場合モアリ、稀二Jolly氏小體ラ有スル赤血球，出現

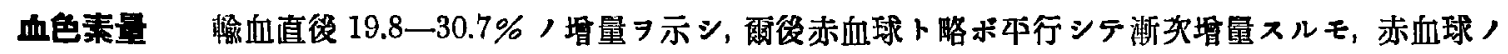

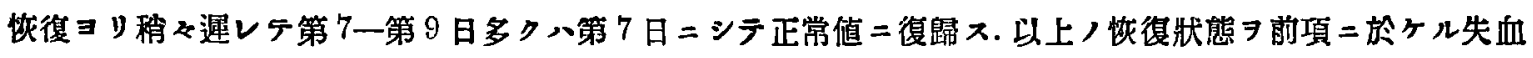

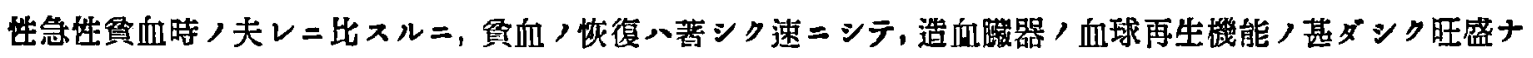
ルコトョ知ルョ得ベシ.

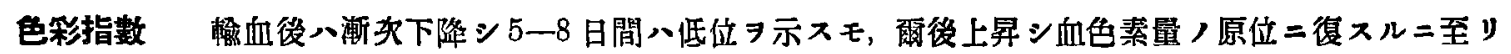
テ本指數モ亦略ボ原位二復菷 ス.

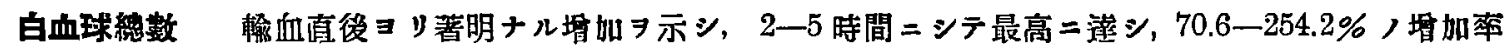

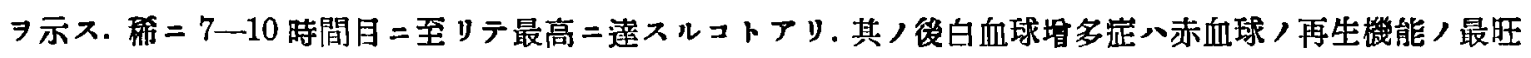

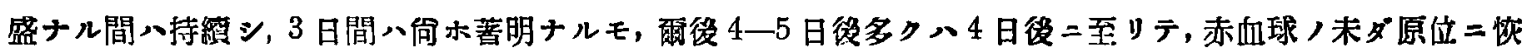
復セザル以前二, 硋堵多症八消失シ正常值二復歸ス。

\section{各種白血球 $/$ 相互的關係}

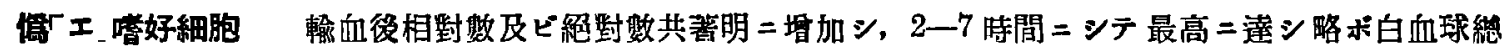

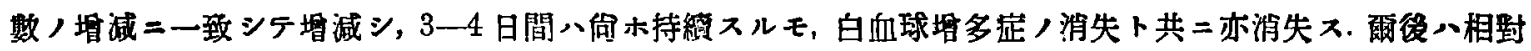
數及ビ絶對數共輕度二減少, 傾向 7 有ス.

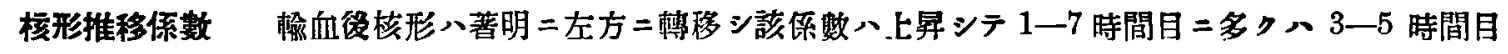

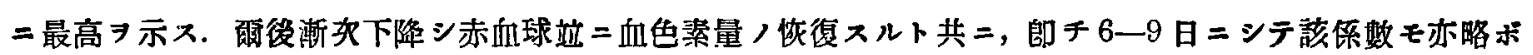

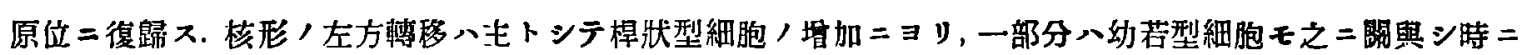

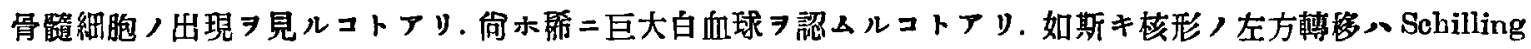
/所謂再生推移珄血液像 regenerative Versobiebung des Blutbildes $=シ テ$, 造血器, 血球再生機能, 旺盛

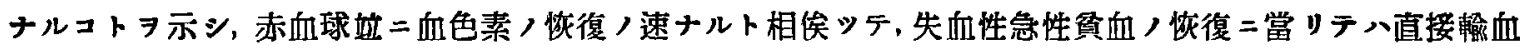
ノ如何二有效ナルカヨ物語ルモノナリ。

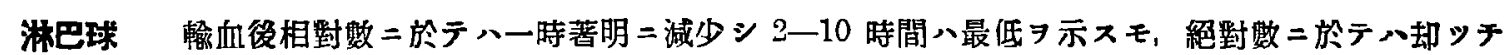
一時剒加ス. 而シテ多クハ2—3 時間月ヨリ八輕度ノ減少 $э$ 示シ, $3-7$ 時間後二最低二達ス. (1 例二於テ

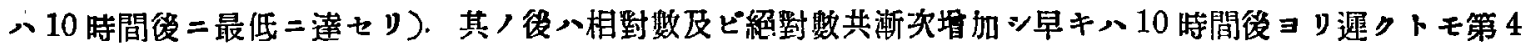

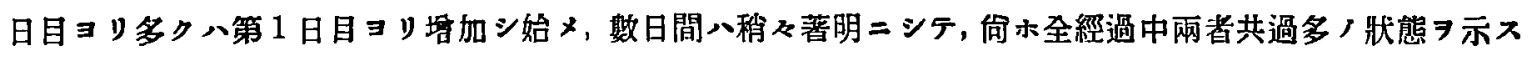
モノ多シ. 輸血後數日間八Türk 氏刺戟型ヨ認ムルコト多シ.

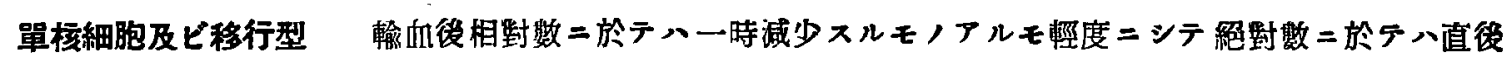

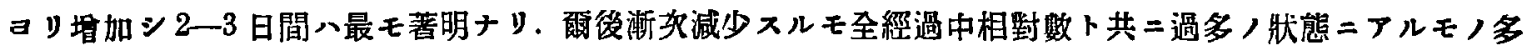
ク時ニ亦著明ナル增加 フ示スコトアリ。

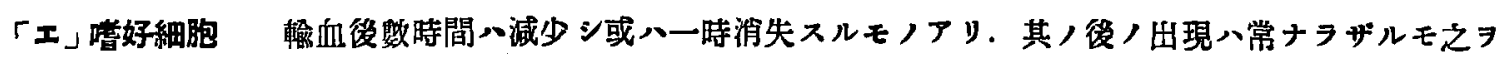

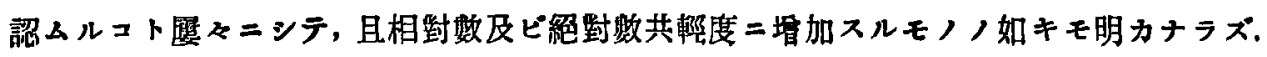

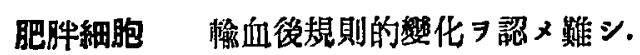




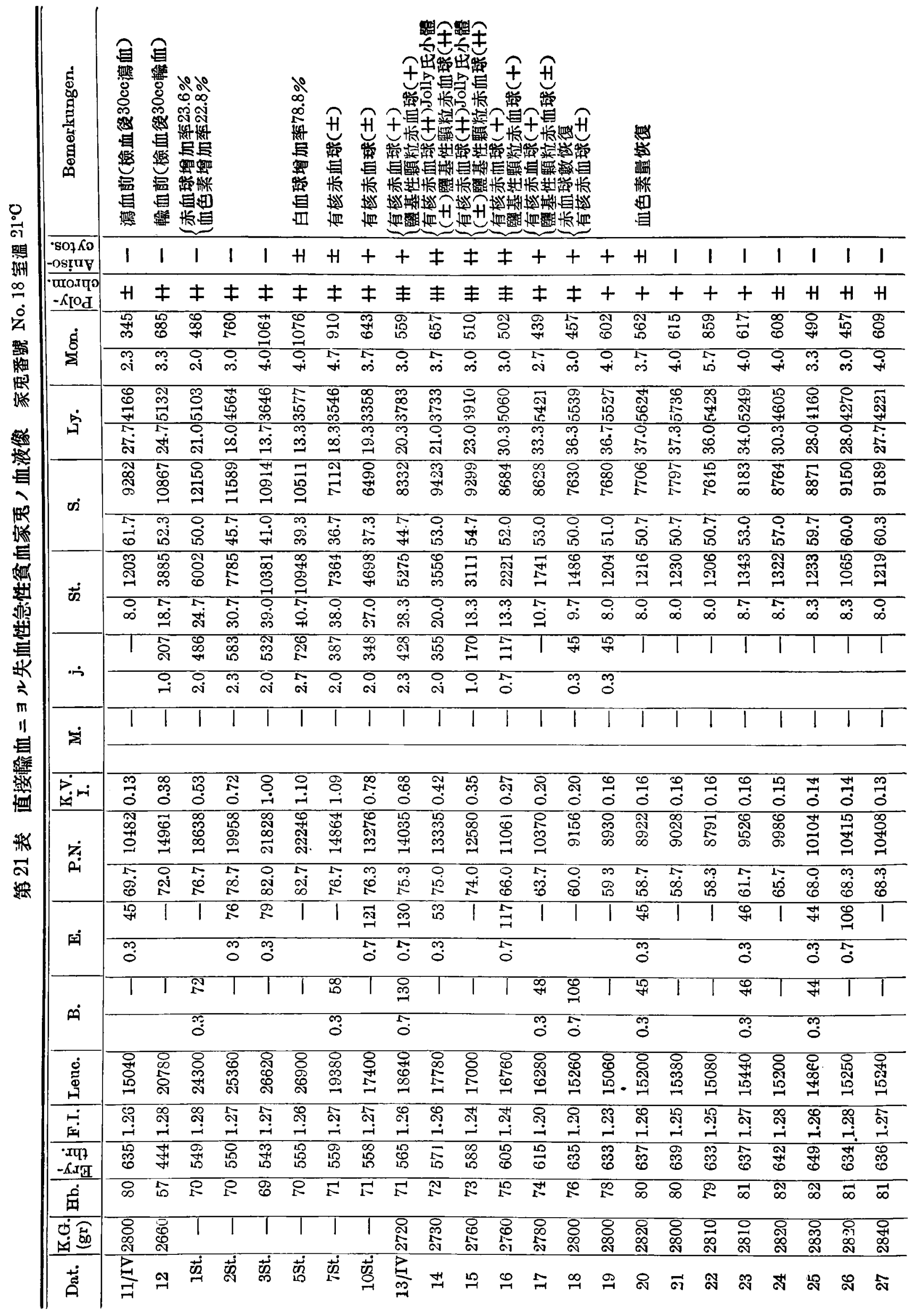




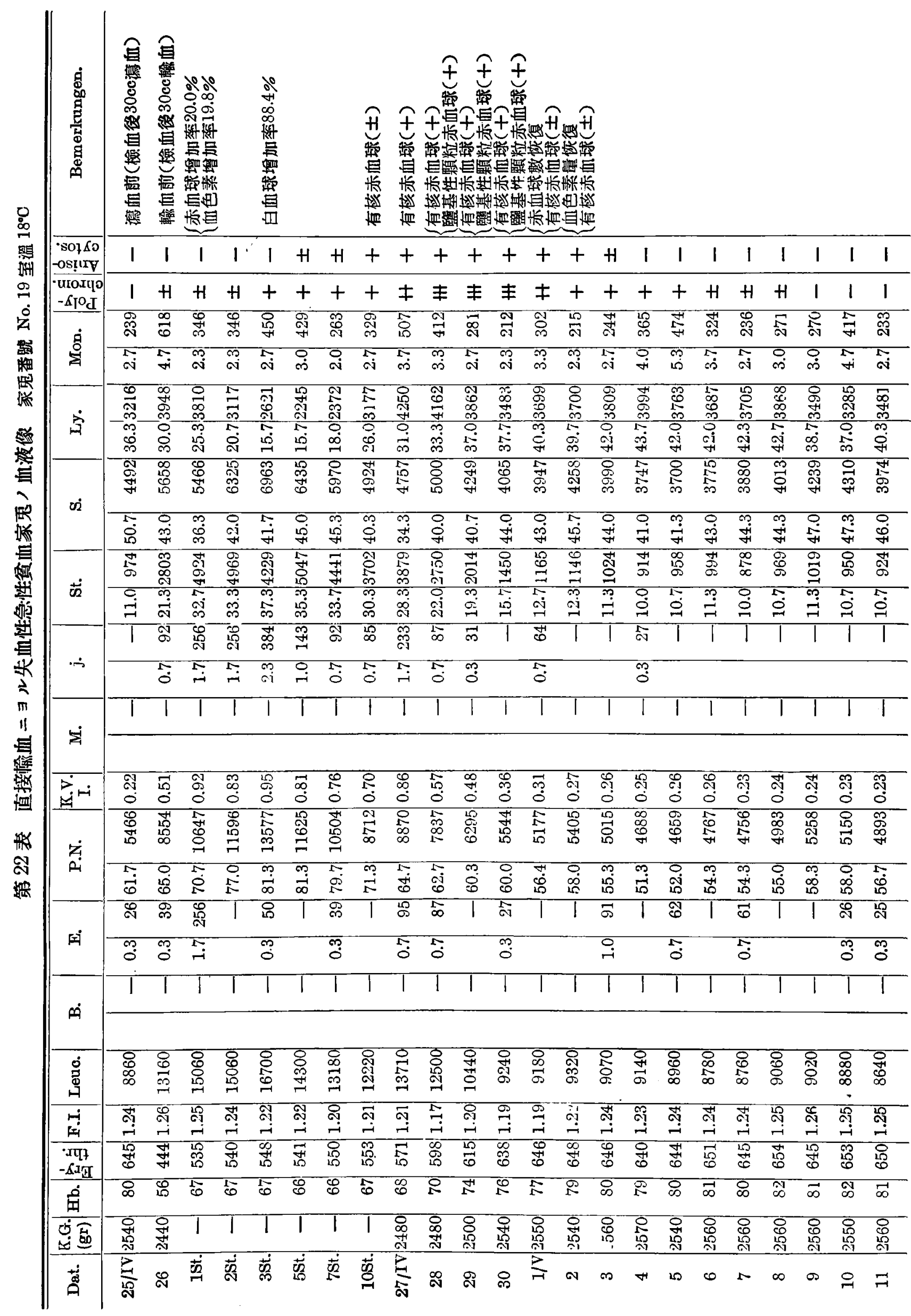




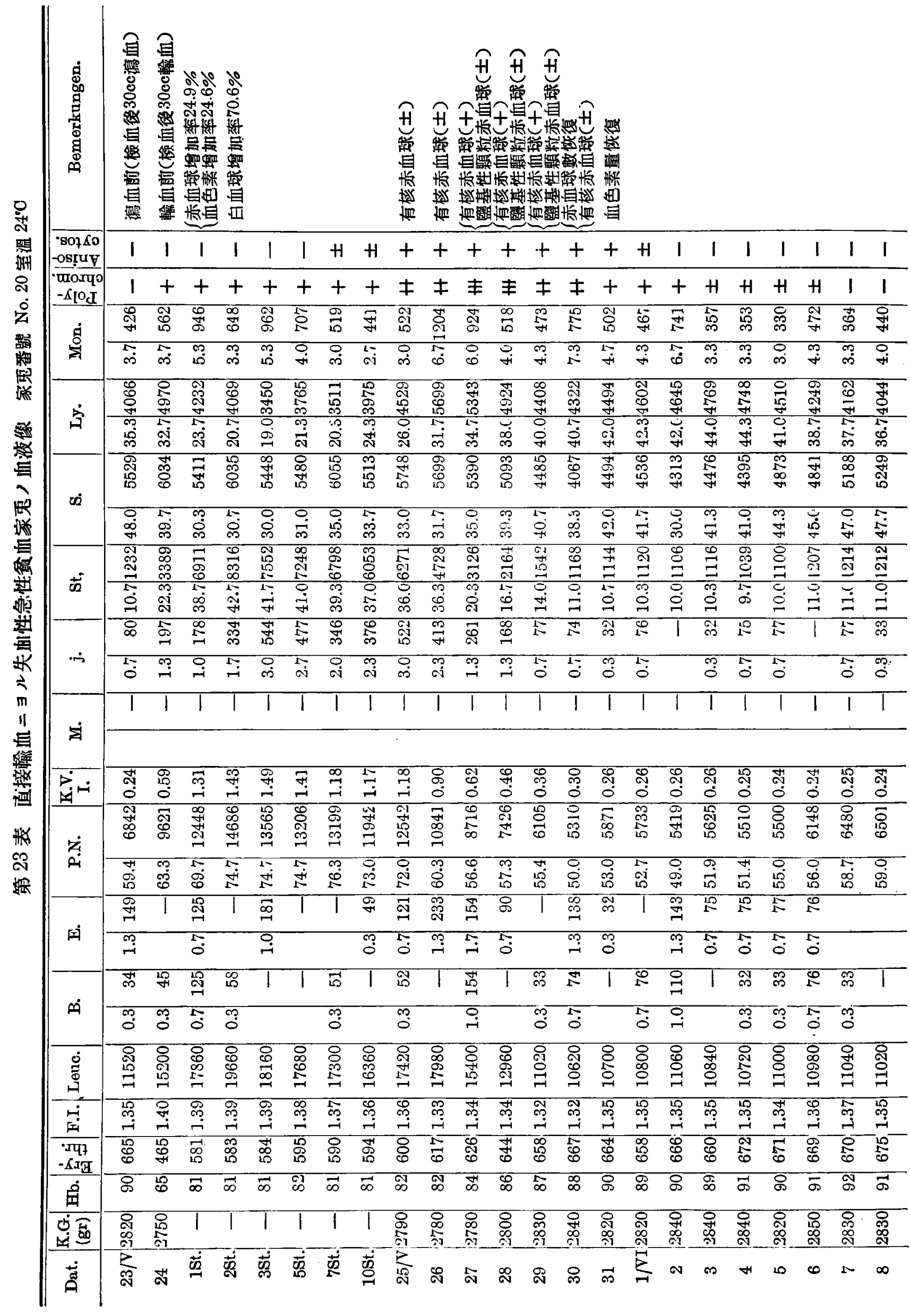




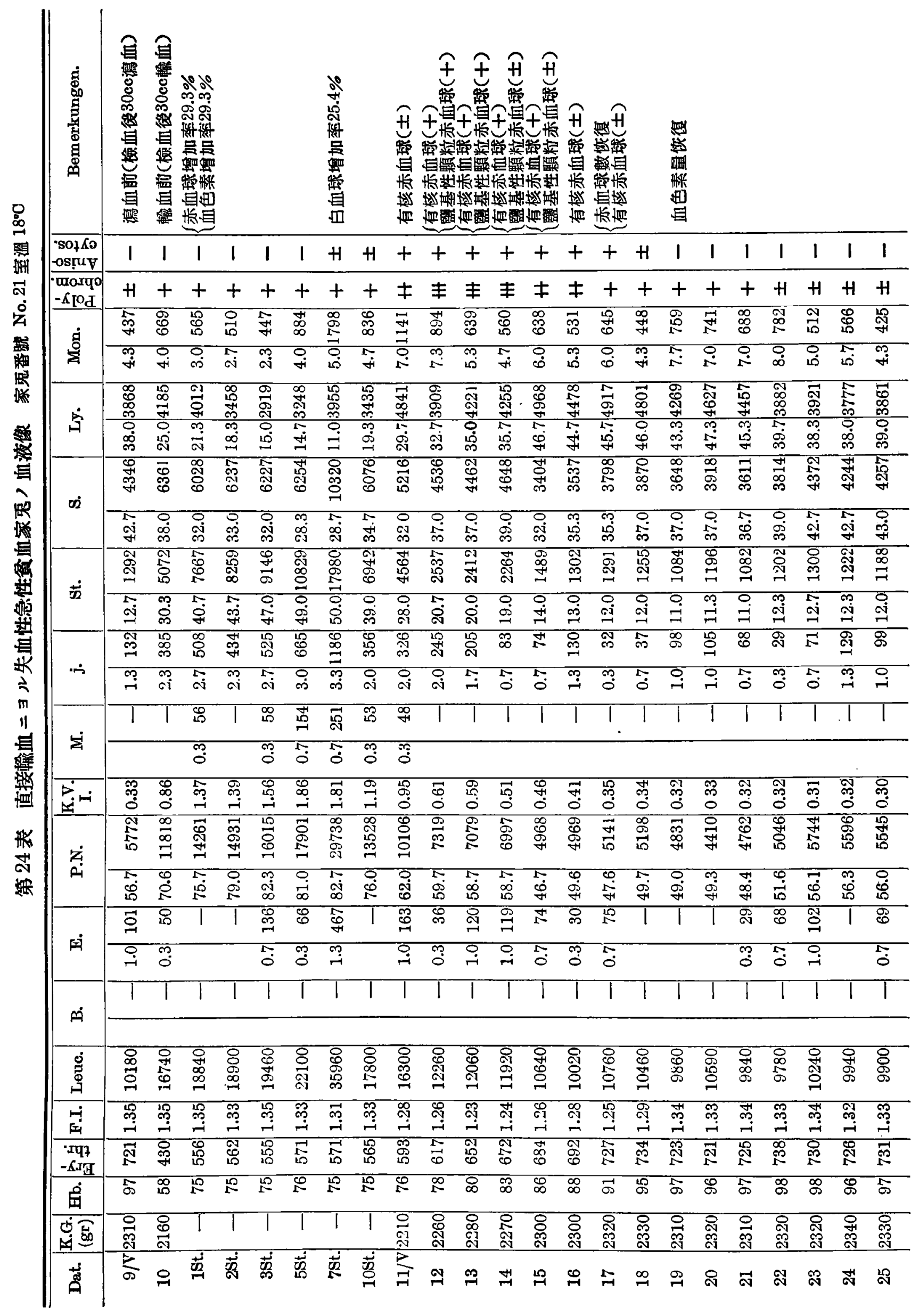




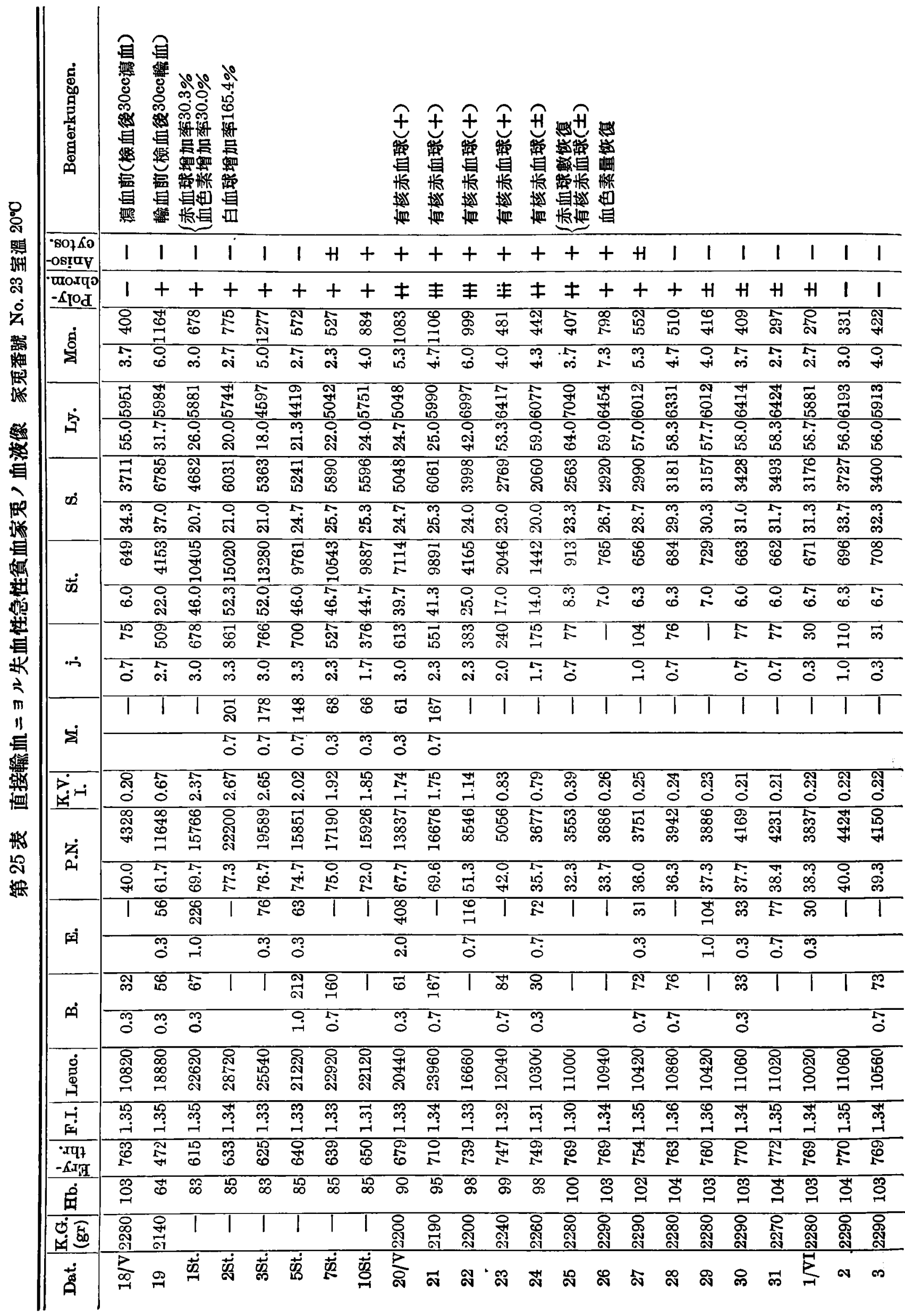




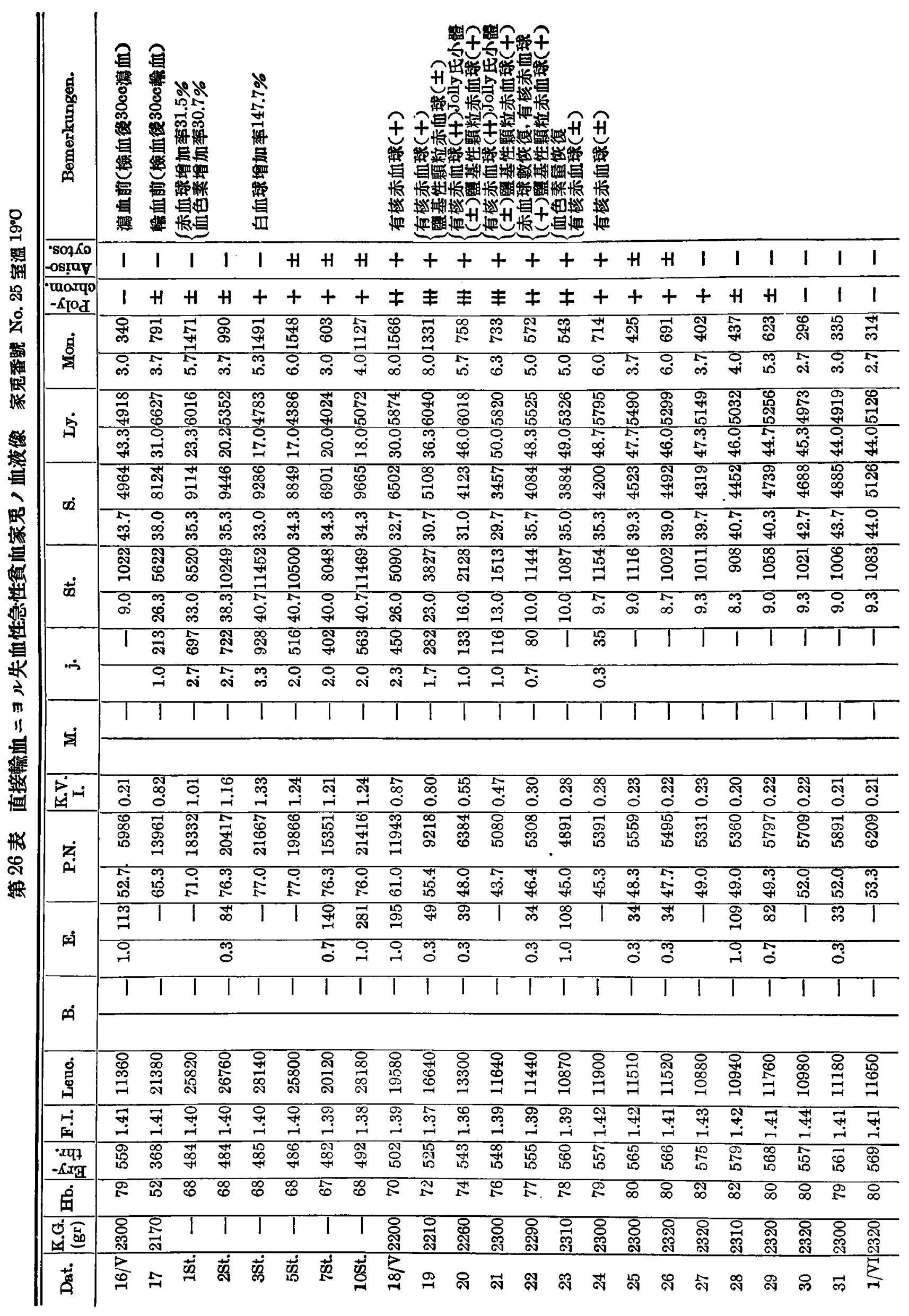


第 1 圖 直接輸血二ヨル失血性急性貧血 家鬼)䯤溫（家鬼番號 No. 18）

輸血 $\downarrow$

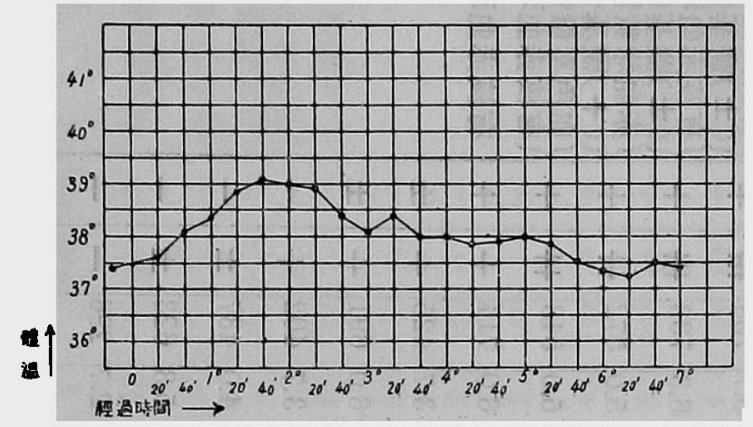

第 3 圖 直接輸血 $=ヨ$ ル失血性急性貧血 家鬼）體溫（家鬼番號 No. 20）

輅血 $\downarrow$

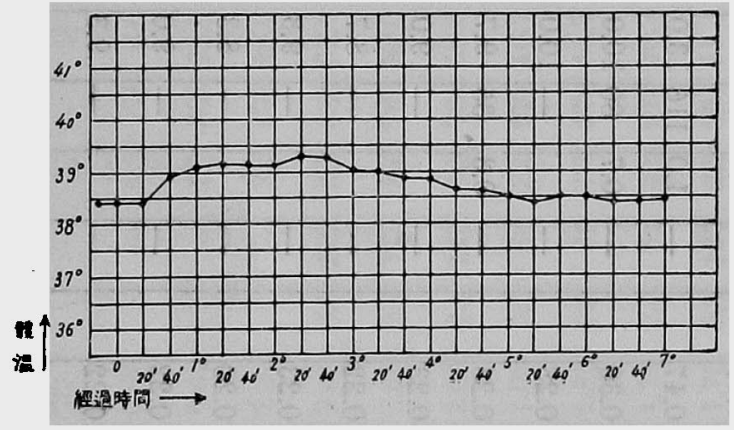

第 5 圖 直接輸血二ョル失血性急性貧血 家鬼）體溫（家鬼番號 No. 23)

輸血 $\downarrow$

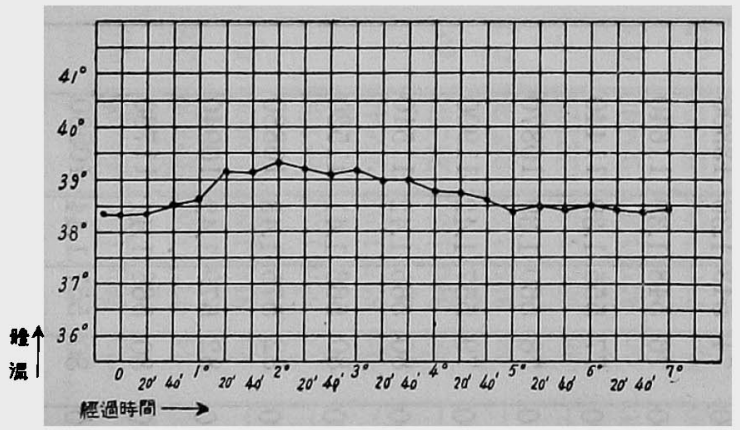

第2 圖 直接輸血二ヨル失血性急性貧血 家鬼)體溫（家蒐番號 No. 19）

輸血 $\downarrow$

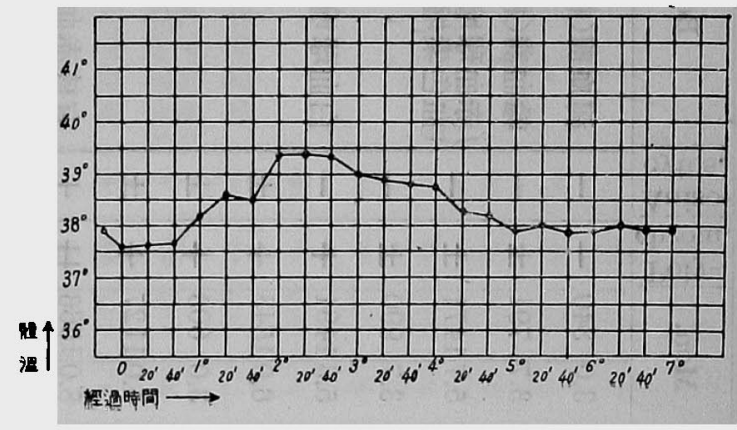

第 4 圆 直接輸血 家鬼）體溫（家鬼番號 No. 21）

\section{䗎血}

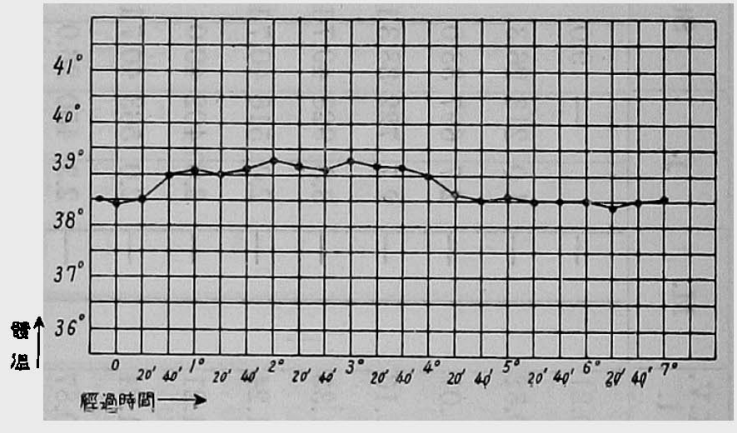

第 6 圖 值接輸血 $=\Xi$ ル失血性急性貧血 家㭸)體溫 (家要番號 No. 25)

輸血 $\downarrow$

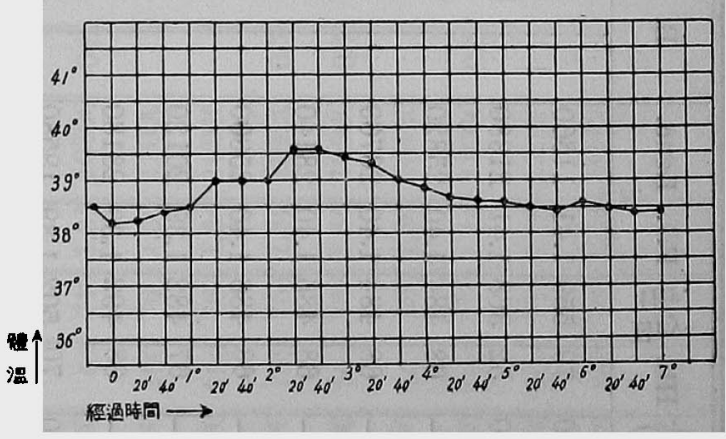


第 3 節构緣酸曹涬血液,間接輸血ニヨル失血性 急性貧血家鬼 血液像，變化站二體溫

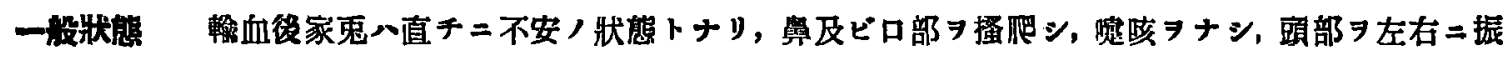

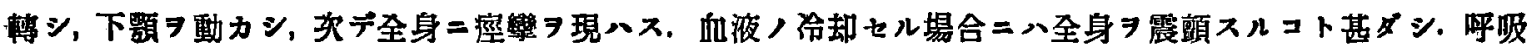

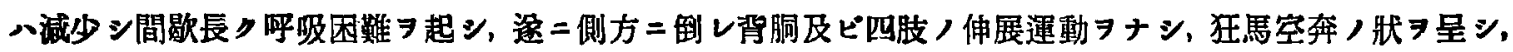

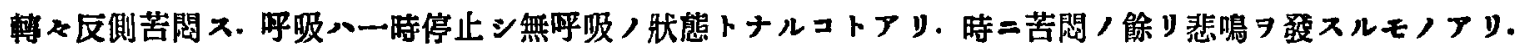

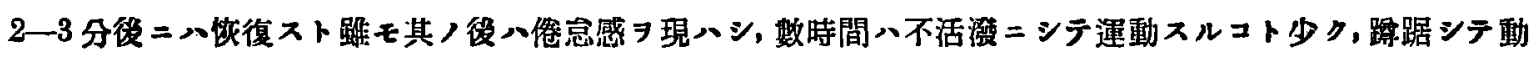
カズ無力ノ狀態

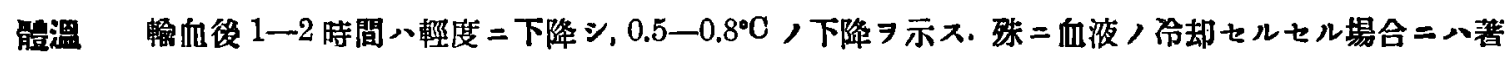
明 シシテ $1^{\circ} \mathrm{C}$ ，下降ヨ示スコトアリ。其ノ後上昇シ $2-4$ 時間後二最高二達ス. 此上昇八比較的著明ニシテ

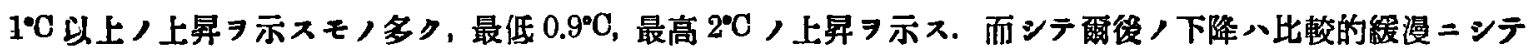

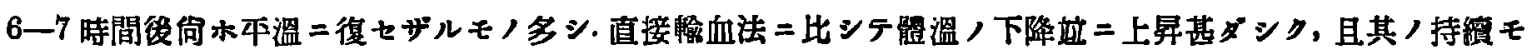
比䡆的長キ 7 知レリ(第 7-12 圖照).

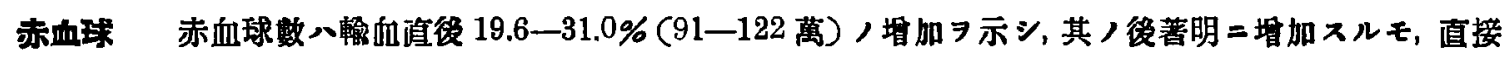

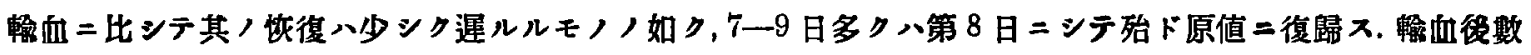

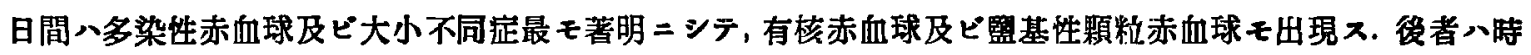

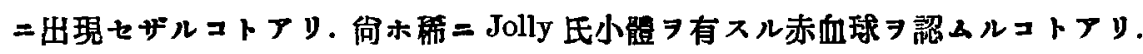

血色素量

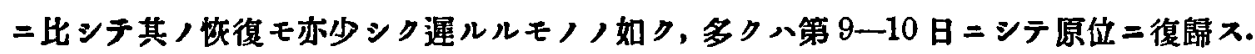

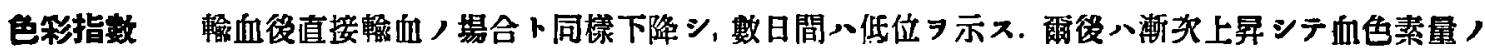
原位二復スルト共二本指数モ亦原位二復歸 $ス$.

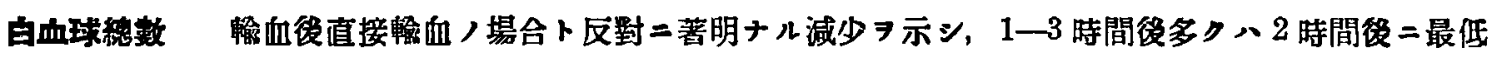

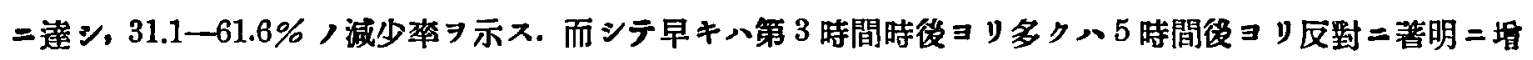
加シ， 5一10 時間後多クハ7時間目二最高二達スルモ, 直接輸血，場合二比シ輕度 =シテ 40.6-236.5\%，

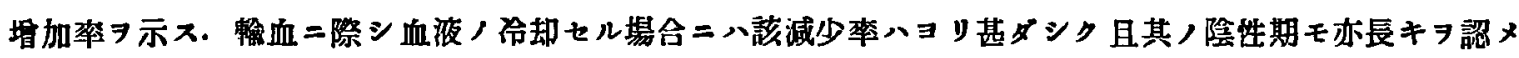

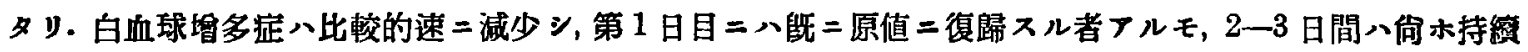
ス者モ】リ. 爾後八著明ナル塯減ナク略ボ生理的圈內

\section{各種白血球ノ相互的關係}

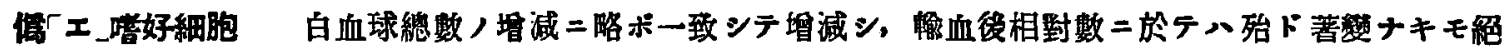

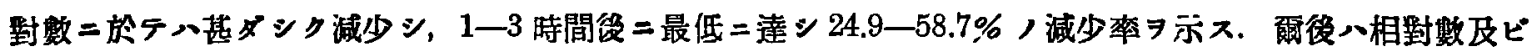

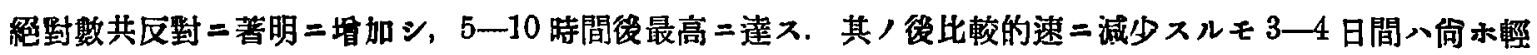

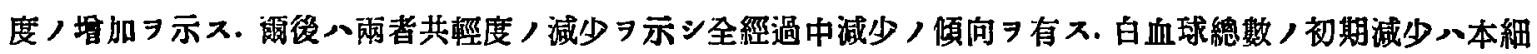

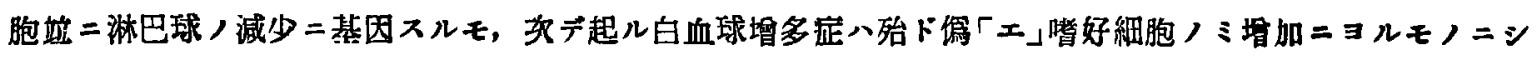
テ、淋巴球ハ却ッテ減少スルモノサーフルヨ認メリ.

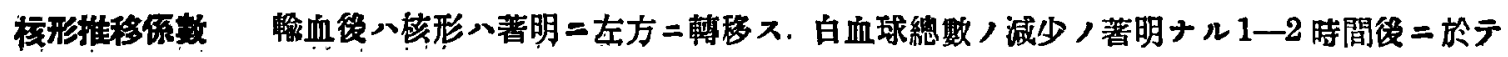




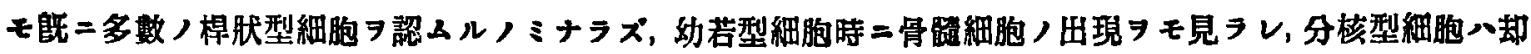

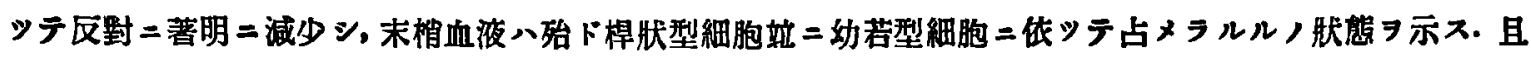

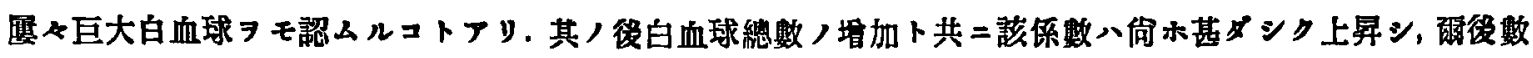

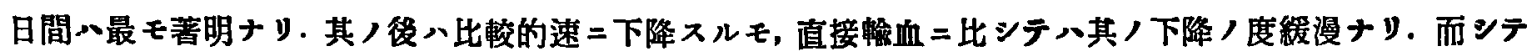

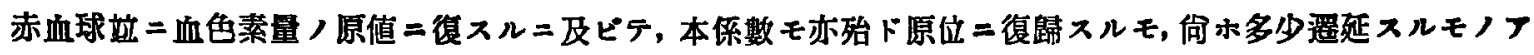

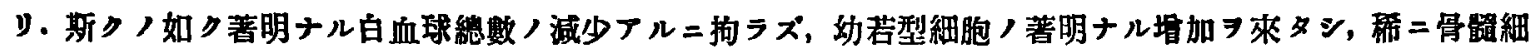

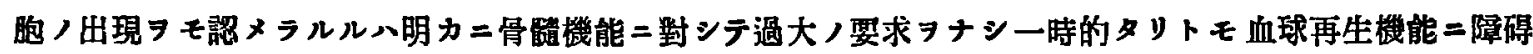

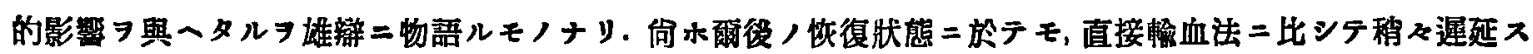

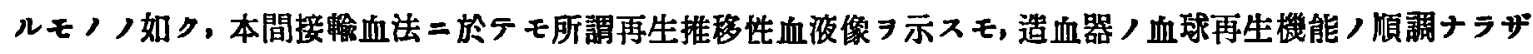
ルョ思ハシムルニ充分ニシテ，直接檪血法二及バザル所ナリ。

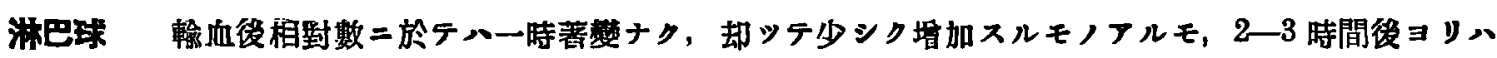

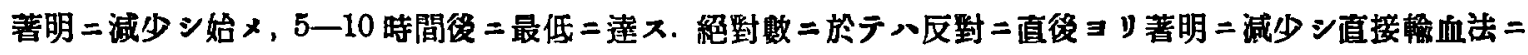

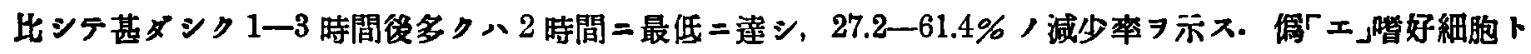

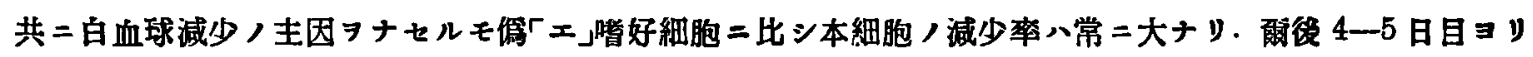

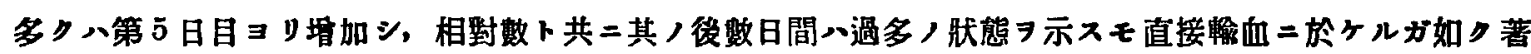

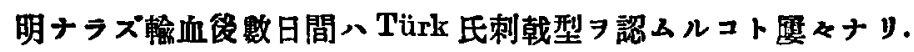

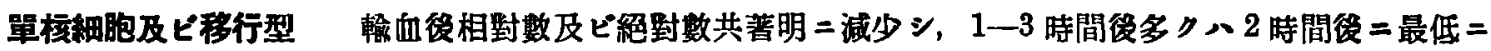

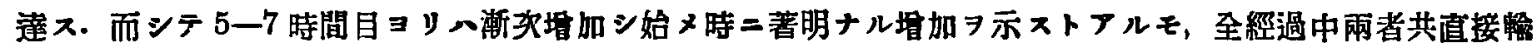
血二於アルガ如ク著明ナル增加 7 見ズ。

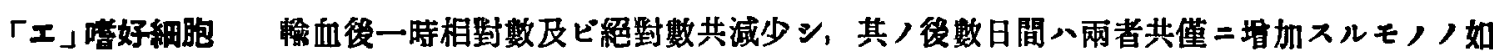
キモー定セズ.

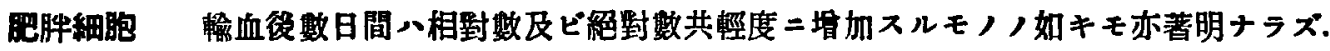

第 4 節 脫繊血液 間接輸血ニヨル失血性急性

貧血家鬼 $>$ 血液像 $>$ 繇化站二體溫

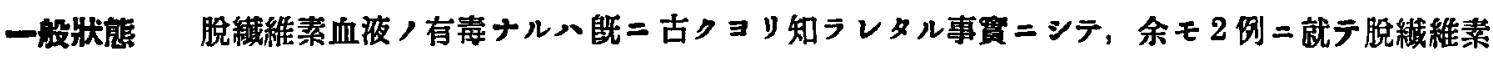

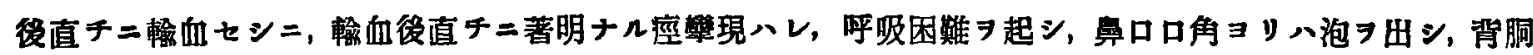

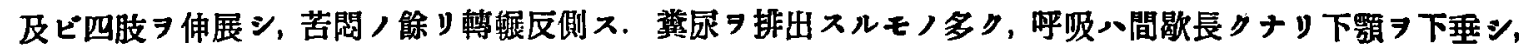

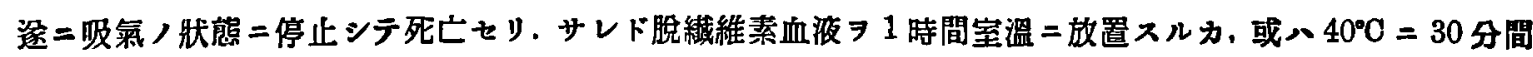

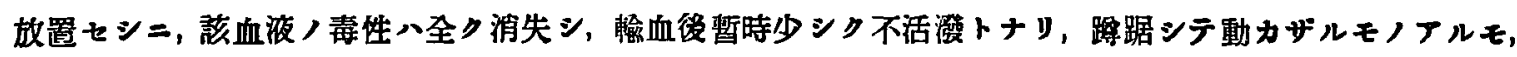

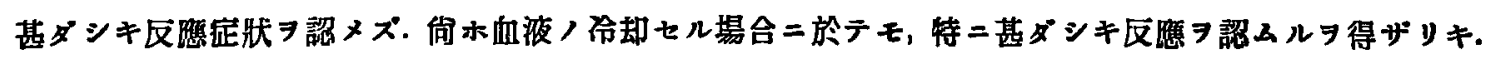

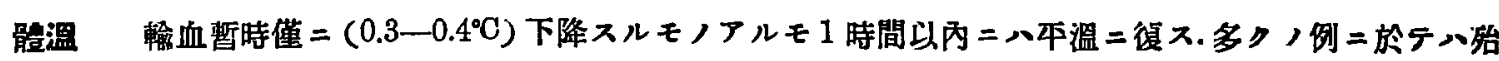
ド下降スルコトナク渐次上昇シテ 2 時間後最高二達ス. 而シテ多クハ $1^{\circ} \mathrm{C}$ 內外，上昇ニシテ且比較的速二下

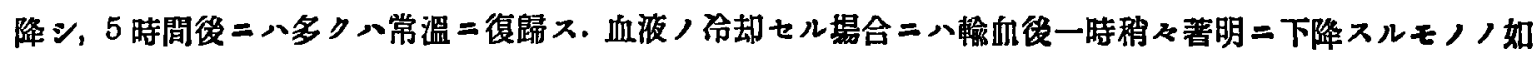

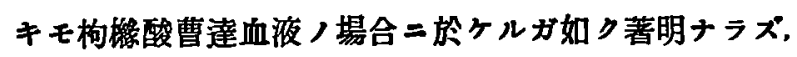

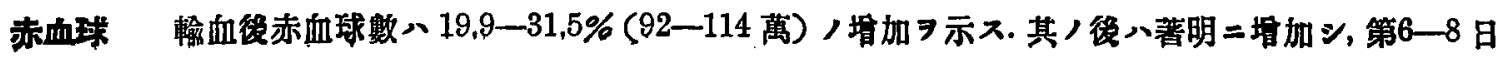




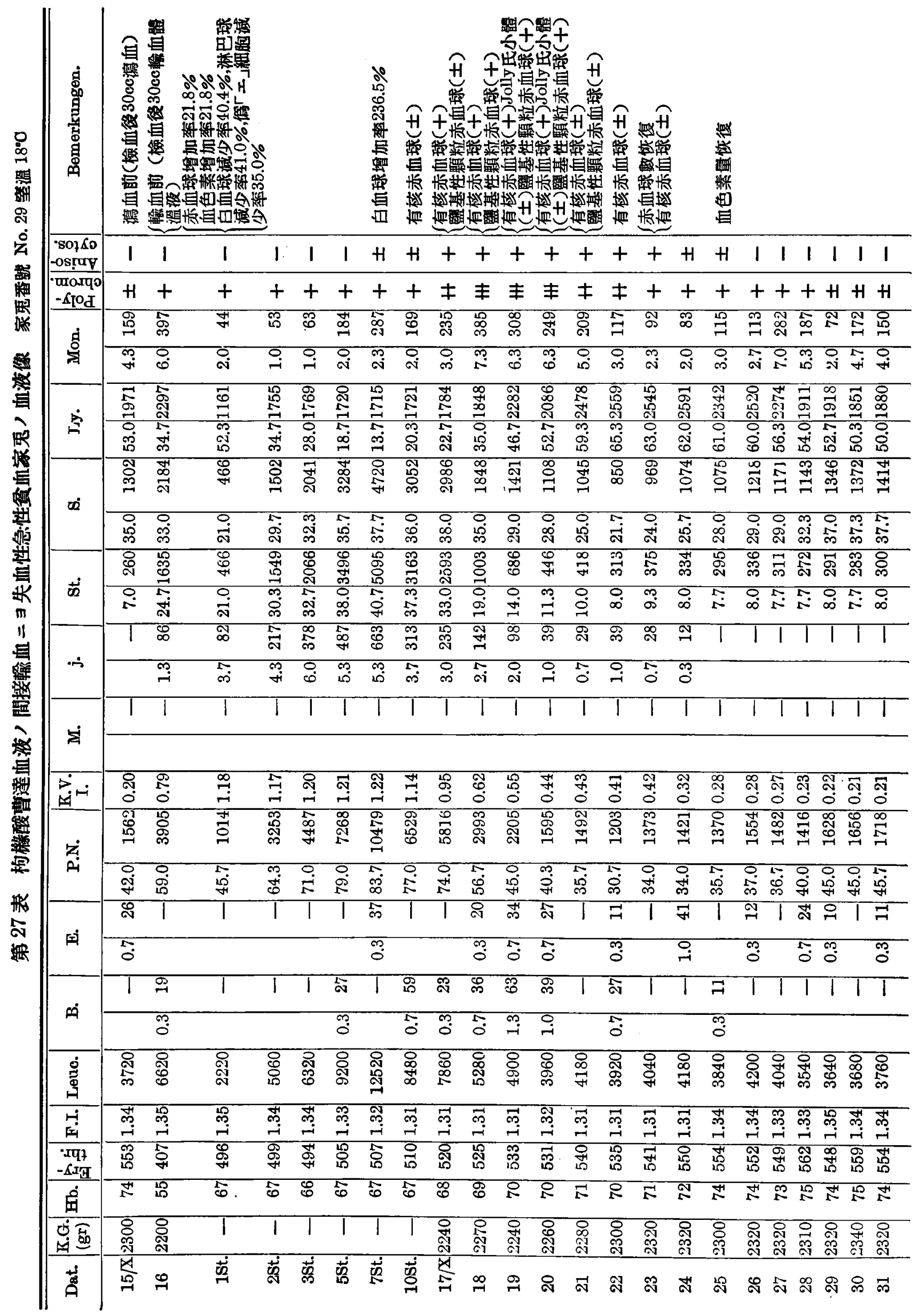




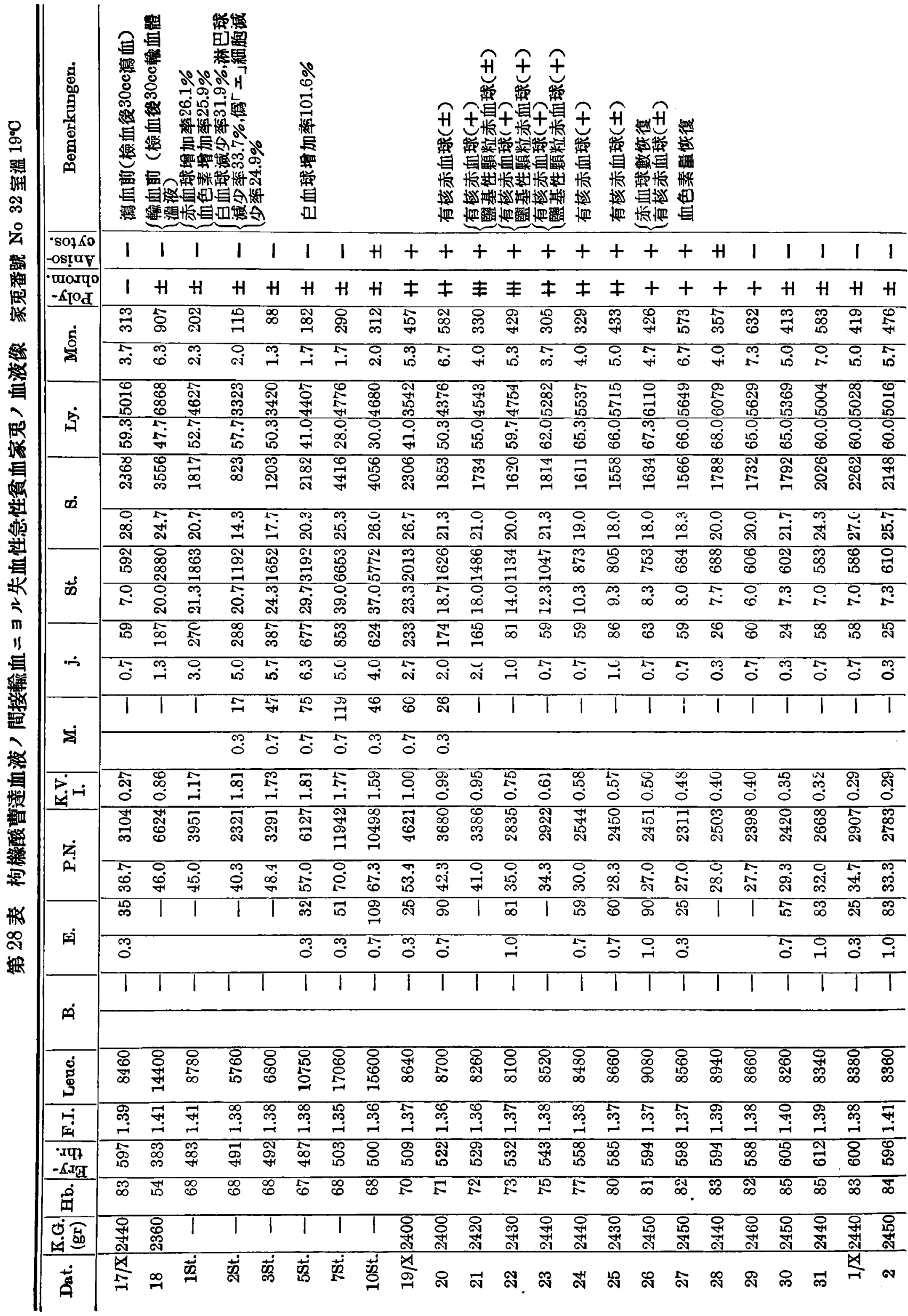




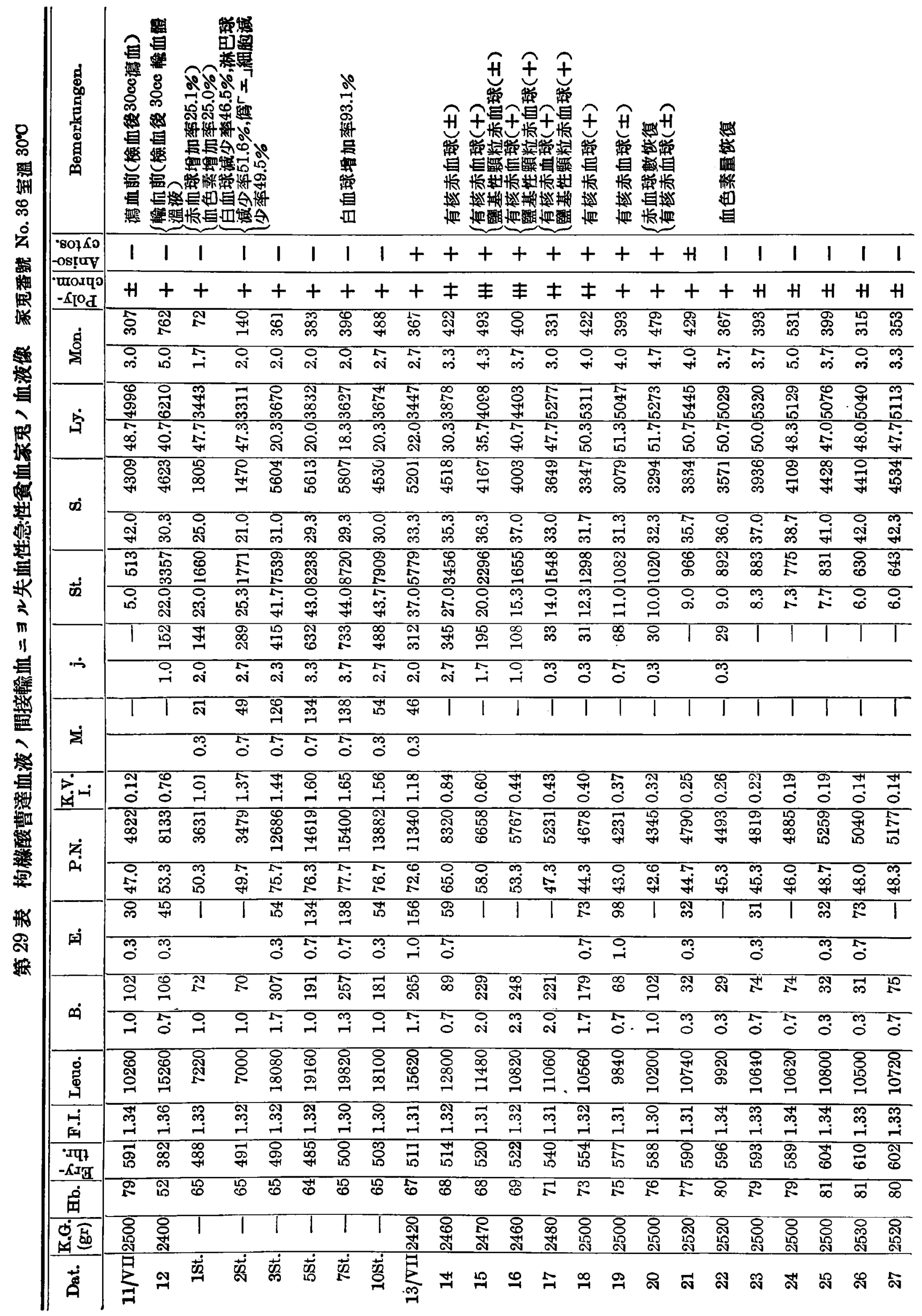




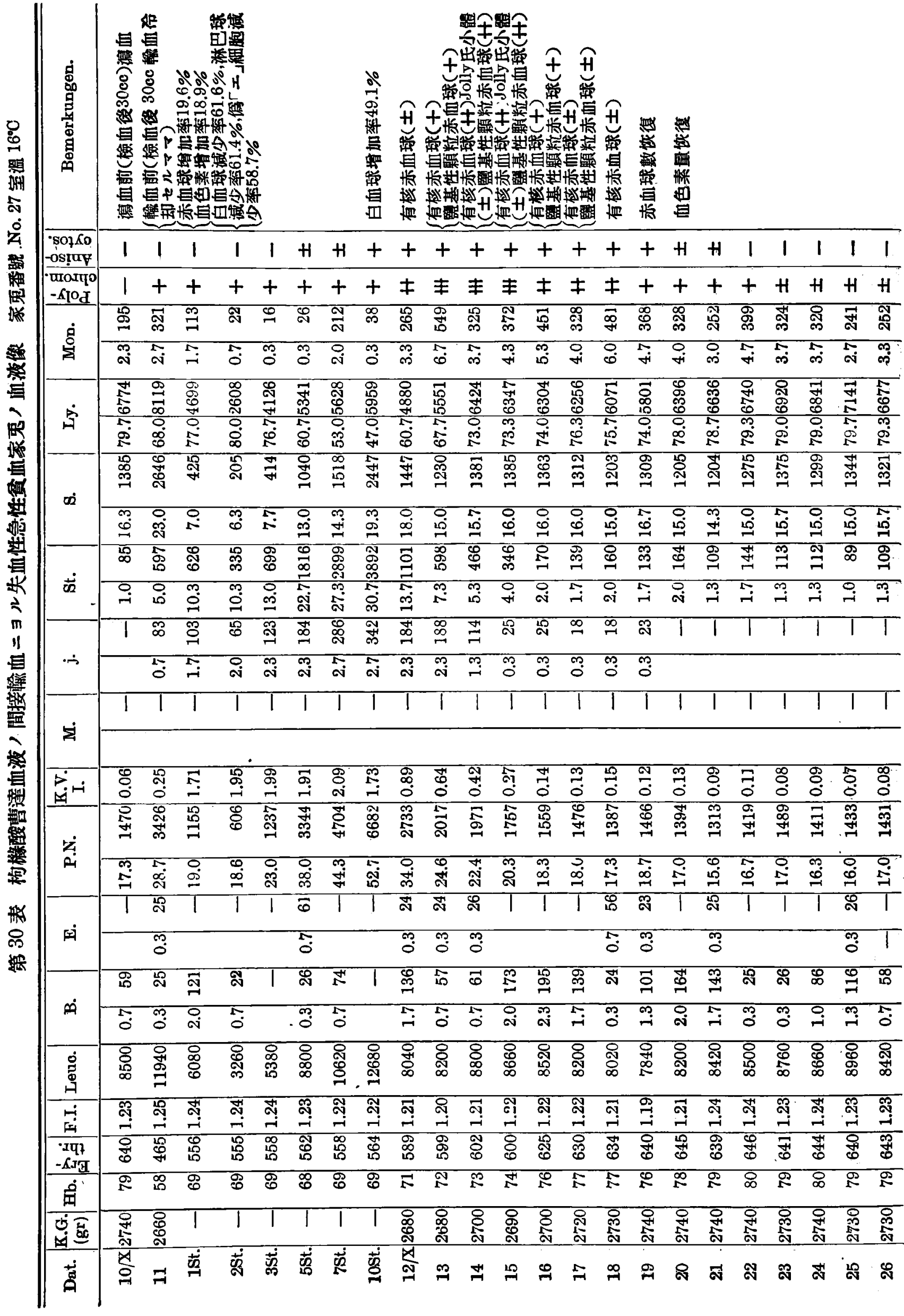




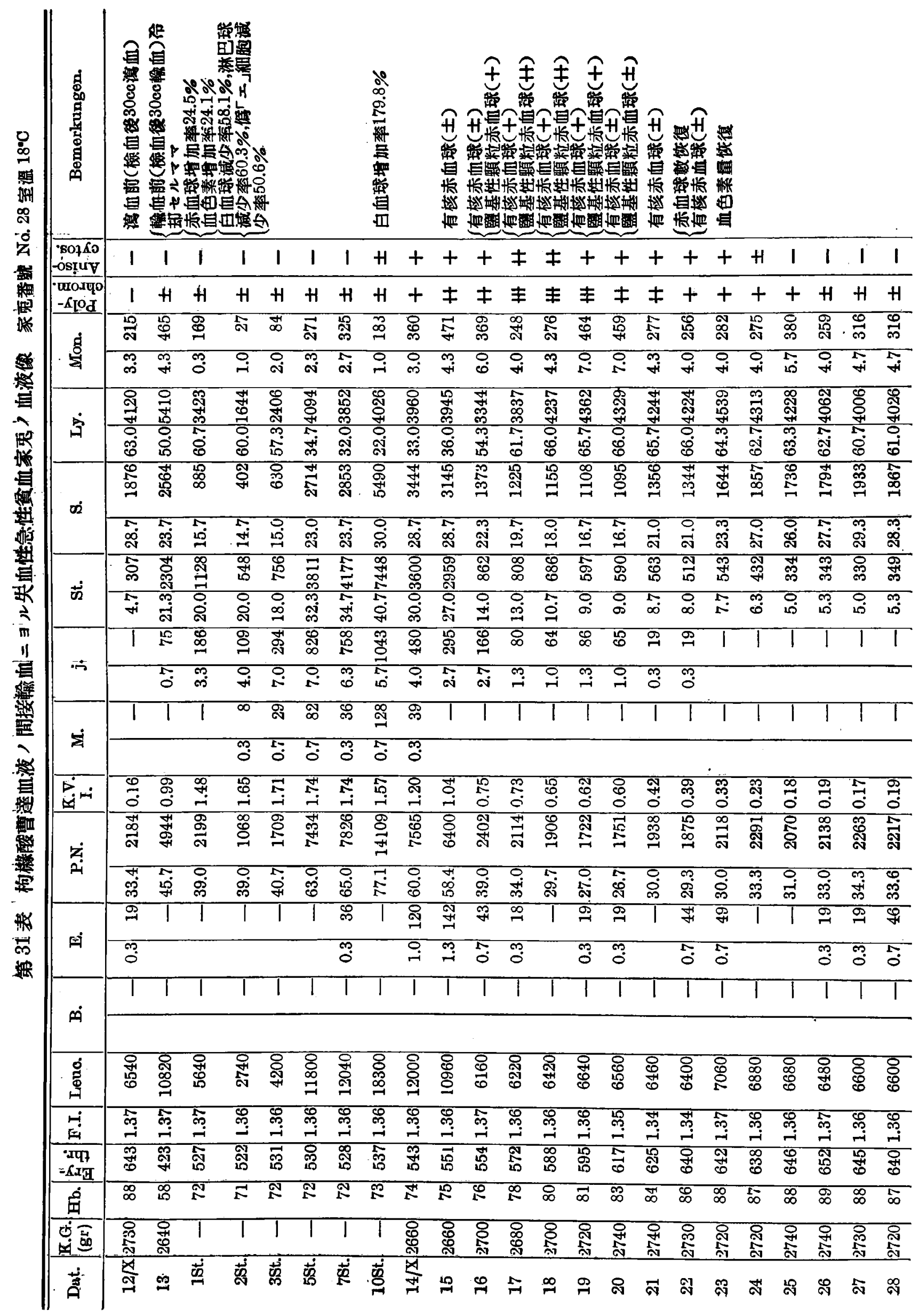




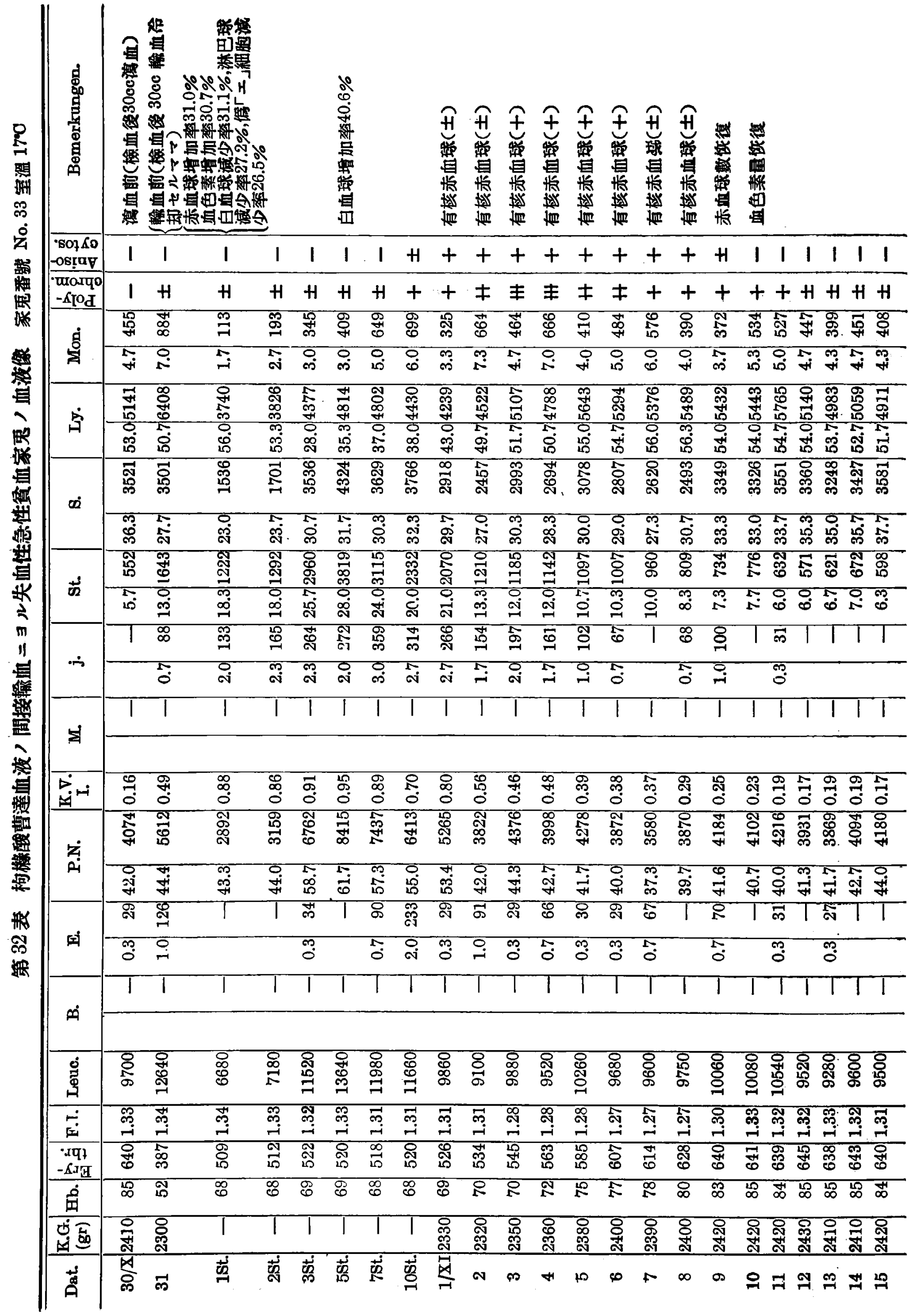




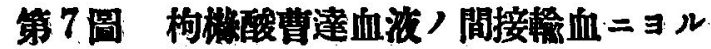
失血性急性負血家鬼ノ體溫

（家鬼番踥 No、29）

望血 $\downarrow$

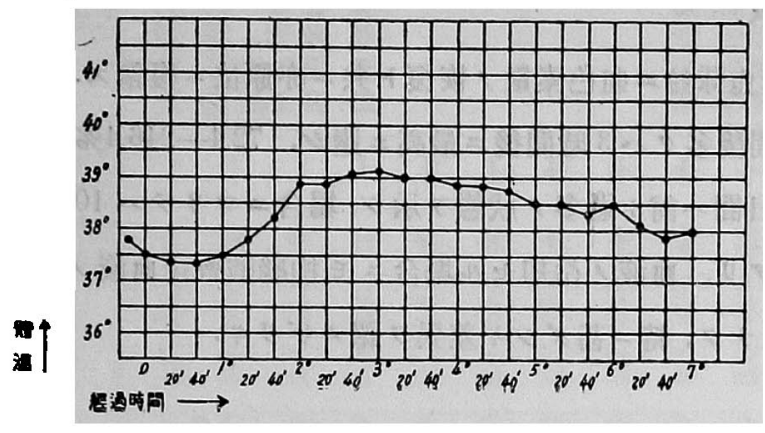

第9圖枸䋇酸曹達血液，間接檢血 $ニ ヨ ル$ 失血性急性貧血家香, 體溫 (家鬼番號 No. 36)

輸血 $\downarrow$

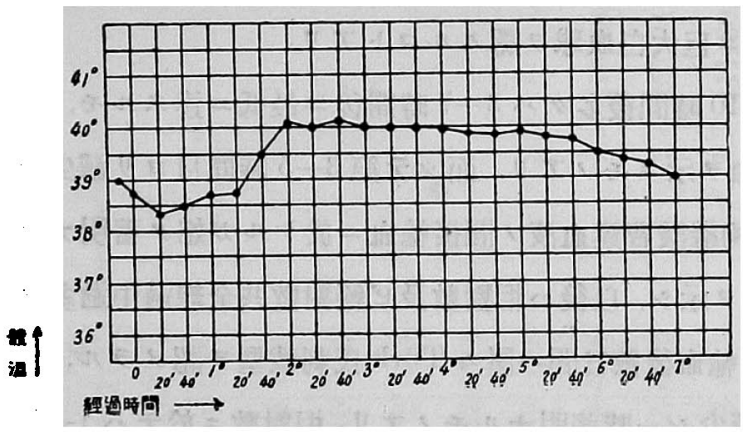

第 11 圖 枸格酸曹達血液, 間接輸血 $ニ ヨ ル$ 失血性急性貫血家鬼，體溫 (家鬼番號 No. 28)

輸血 $\downarrow$

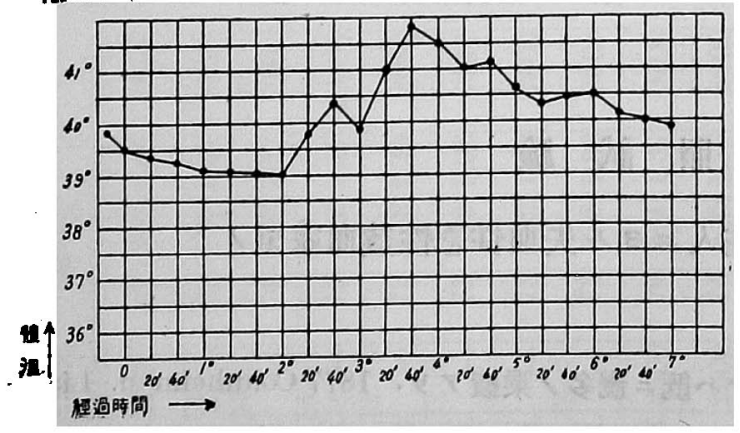

第 8 圖 构楼酸曹達血液ノ間接榆血ニヨル。 失血性急性貧血家鬼 2 體溫

(家鬼番號 No. 32)

羷血 $\downarrow$

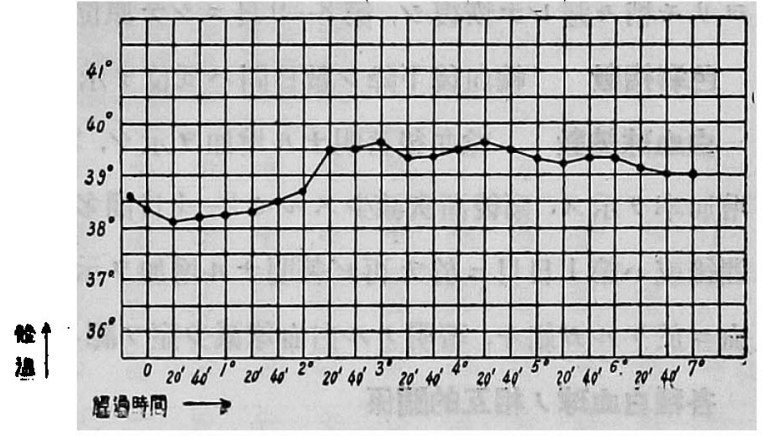

第 10 圖枸格酸曹達向液, 閒接輸血 $=ヨ ル$ 失血性急性圎血家鬼, 䯤溫 (家鬼番號 No. 37)

輸血 $\downarrow$

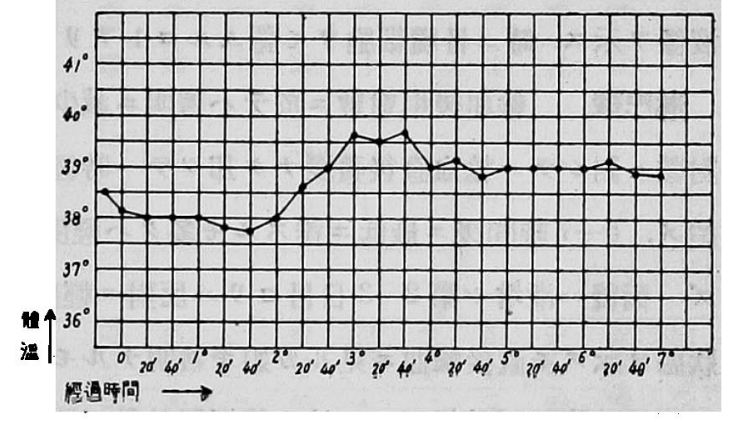

第 12 圖枸格酸曹達血液, 間接輸血 $=ヨ ル$ 失血性急性賀血家鬼／體溫 (家鬼番號 No. 33)

軺血 $\downarrow$

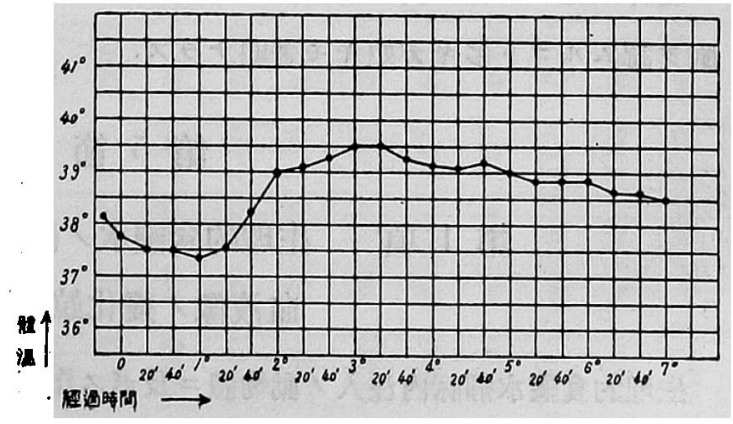




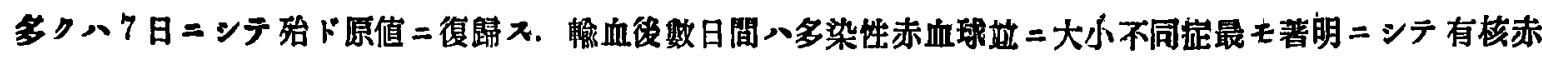

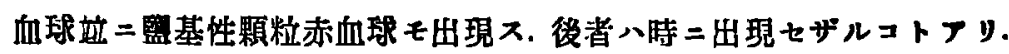

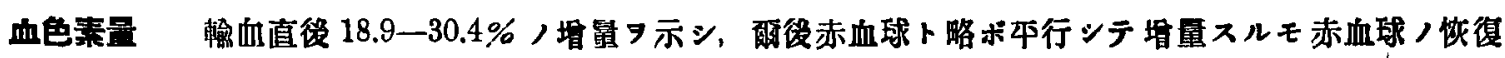
ヨリモ稍く遲レテ恢復シ，第8一9日ニシテ原位二復歸ス。

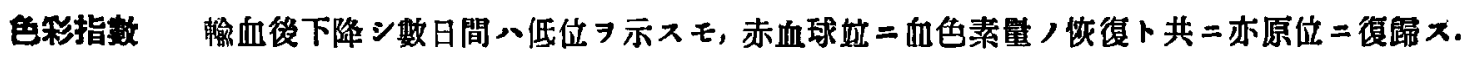

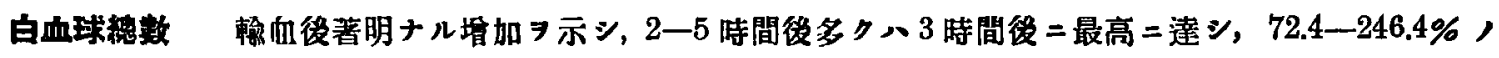

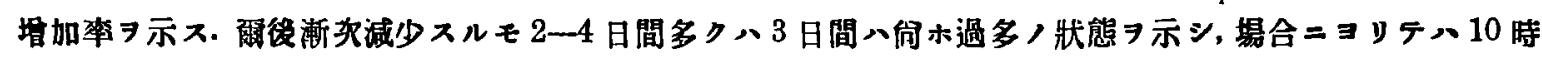

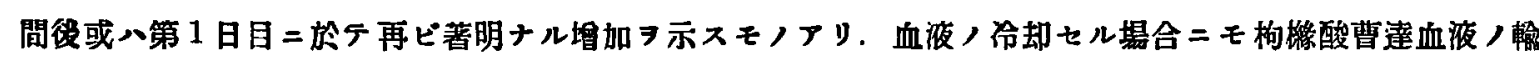
血二於ヶルガ如キ，著明ナル白血球堿少症习認ムルコトナク，特二甚ダシキ差異ヨ認メザリキ。

\section{各種白血球ノ相互的的牦}

㙁「エ_㗪好細胞本細胞八白血球總数增減ノ主因シナスモノニシテ,略ボ之ト本行シテ增減ス。輸血後

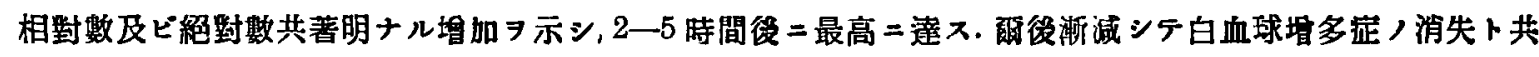
二消失シ，以啳八輕度, 减少

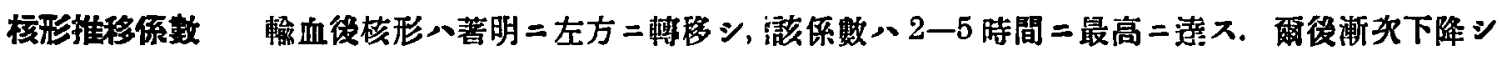

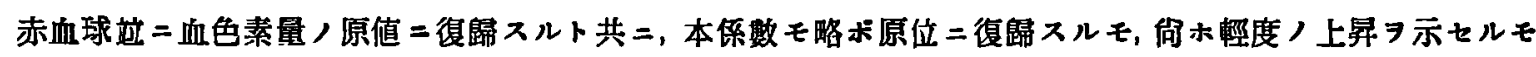

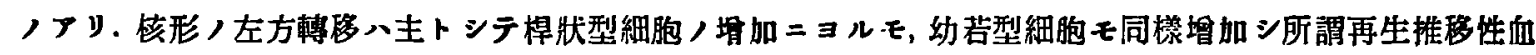

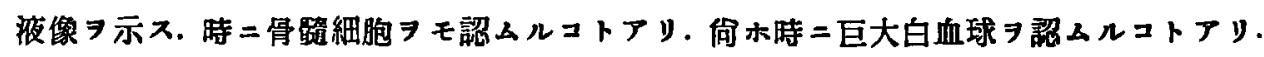

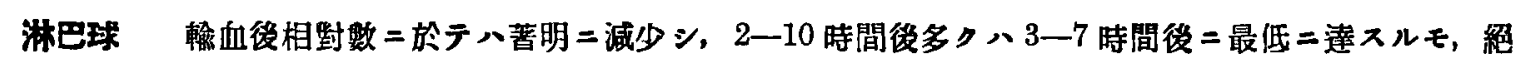

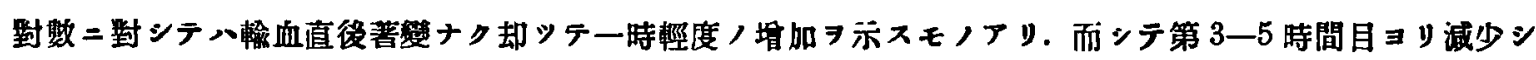

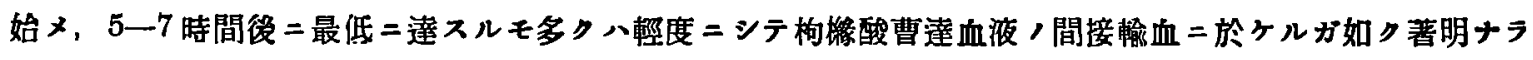

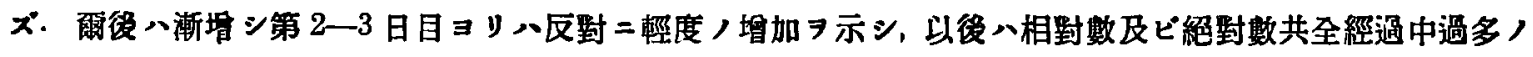

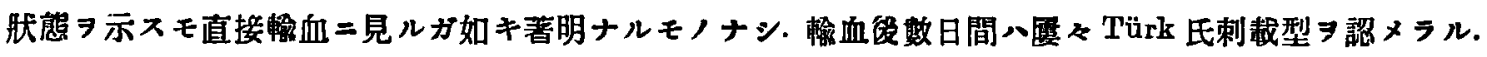

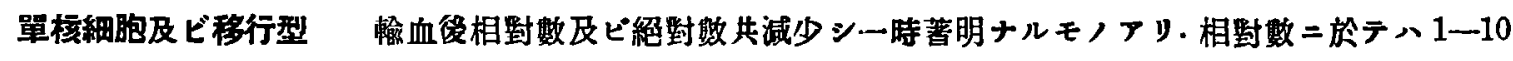

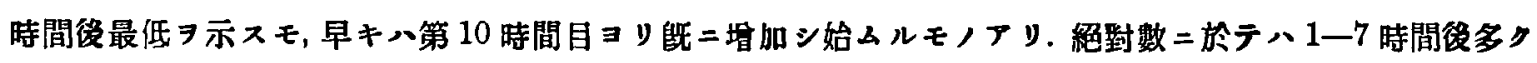

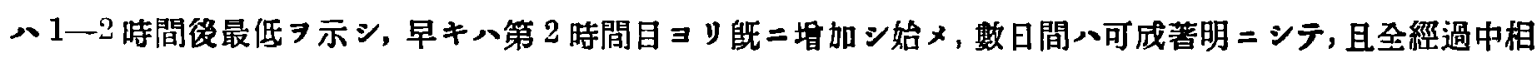

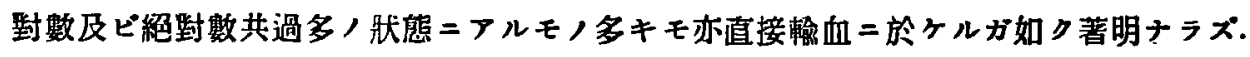

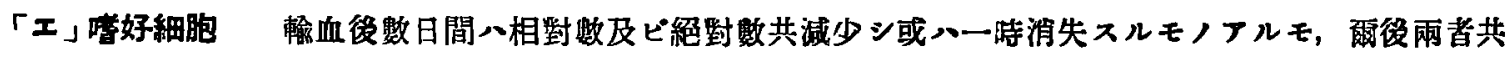
輕度二增加スルモ，如ク，全經過中本細胞，出現习見ルコト嫮そナリ。

肥㭌湅胞輸血後相咥數及ビ絕對數共一時減少スルモノ八如ク，爾後兩者共僅二增加シ全經過中本細 胞ヨ認ムルコト多キガ如キモ著明ナラズ.

\section{第 5 節 㭙 照 試 驗}

第 1 項生理的食鍳水, 静脉內注入二ヨル失血性急性貧血家鬼, 血液像, 變化站 $=$ 體溫

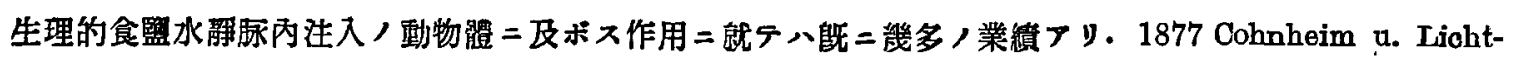
heim (135), 次デ 1888-1889 Distre u, Loye (135) 等ノ之二關スル潑表习始メトシ，其，後 Knoll (135) 


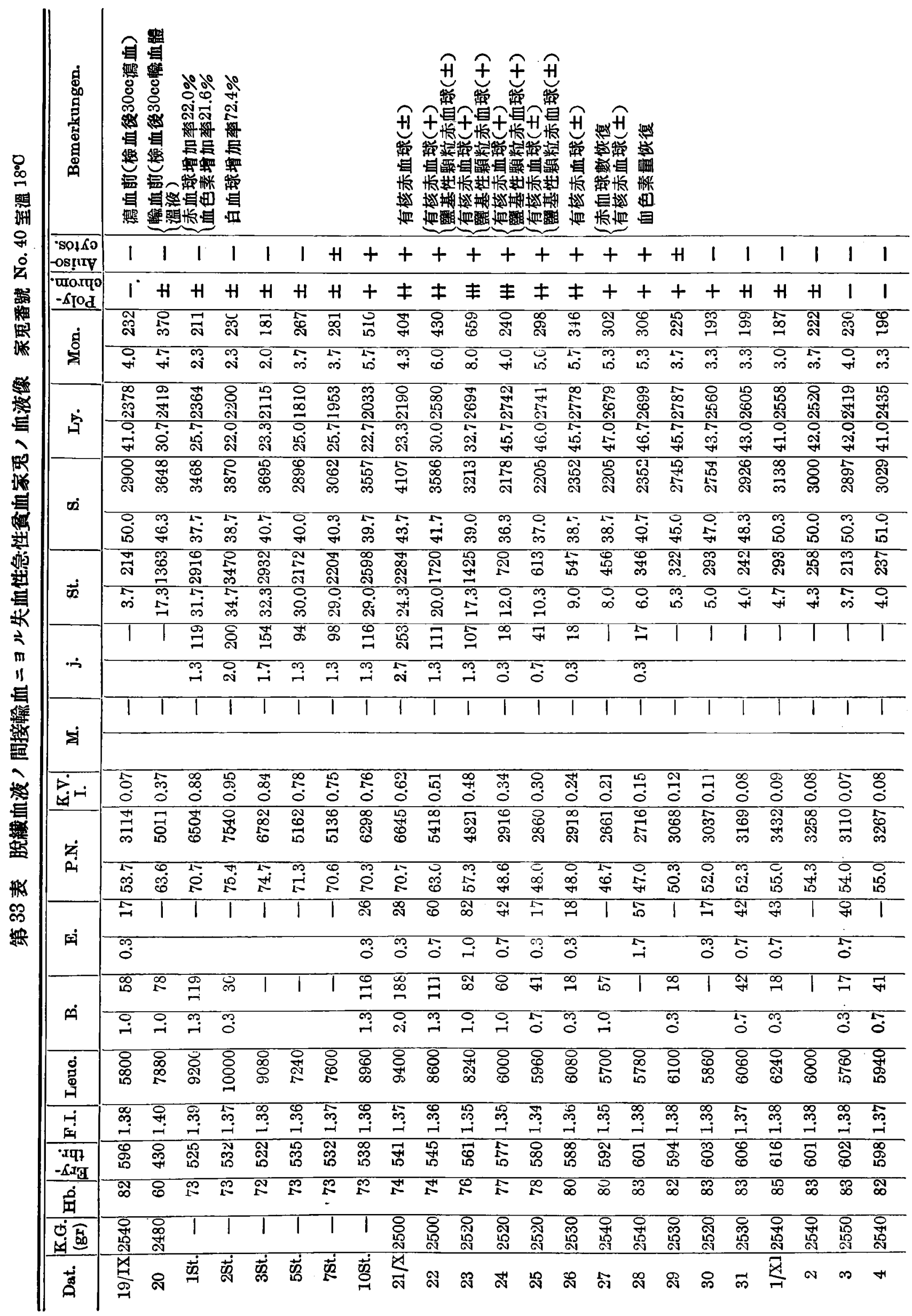




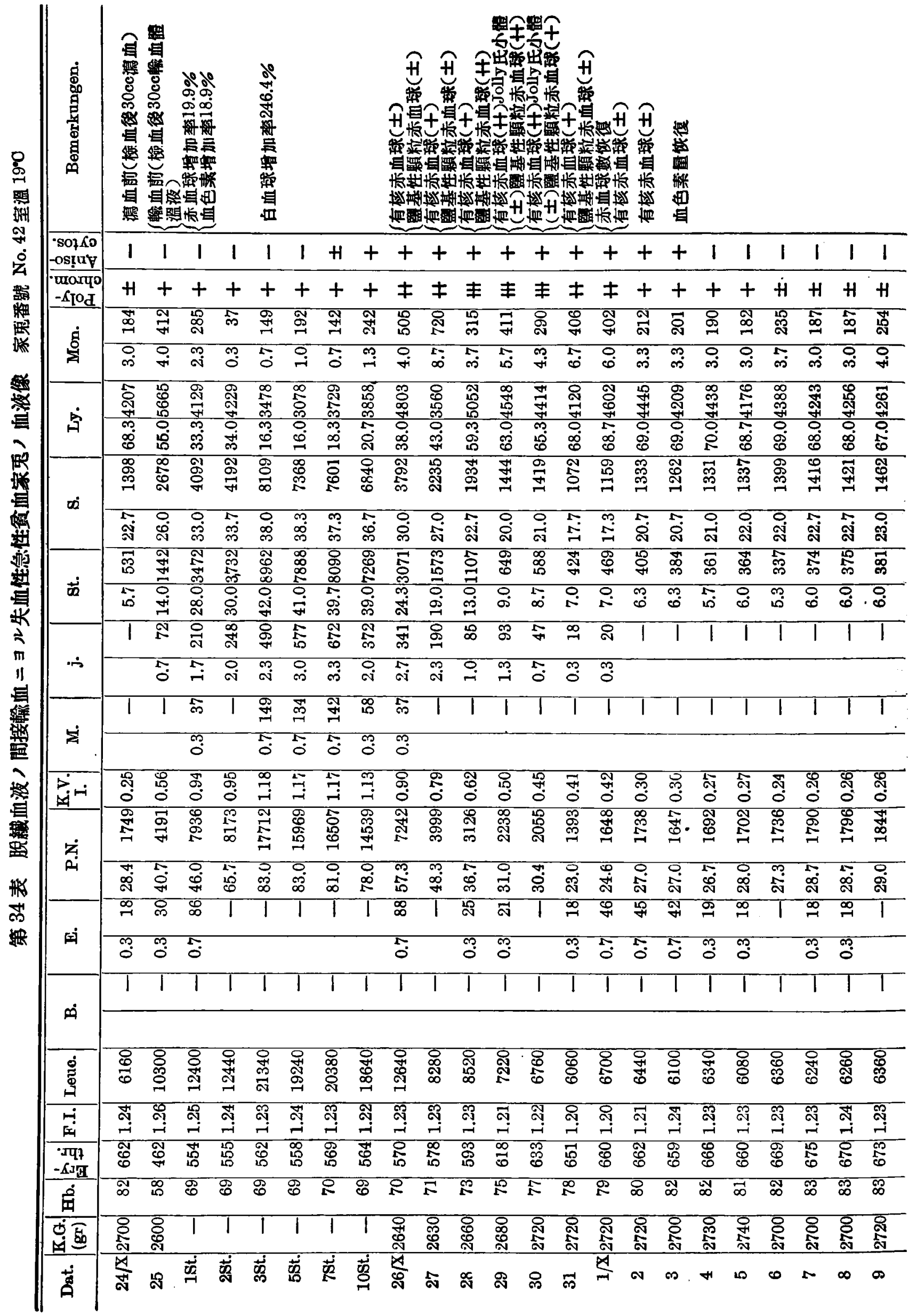




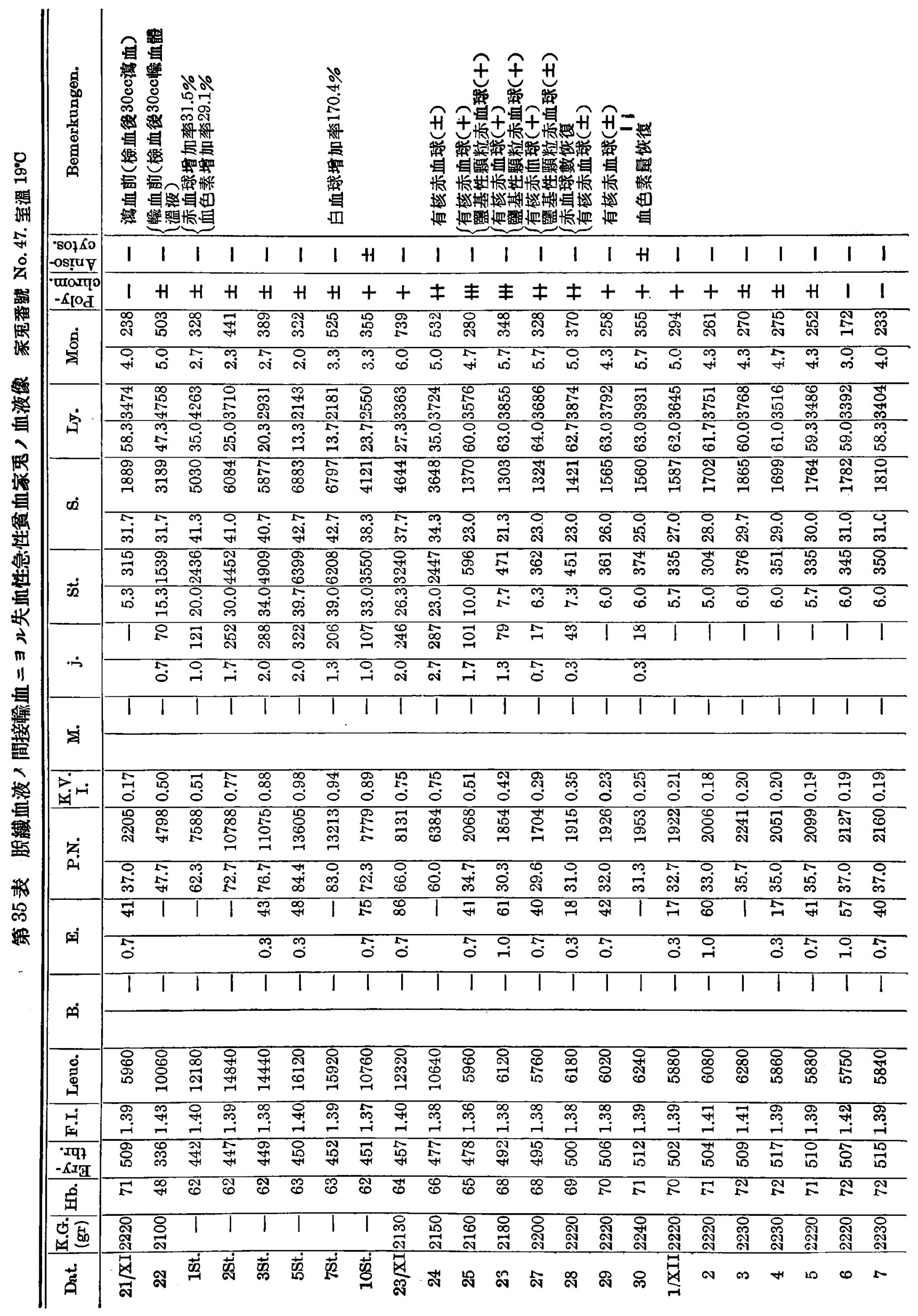




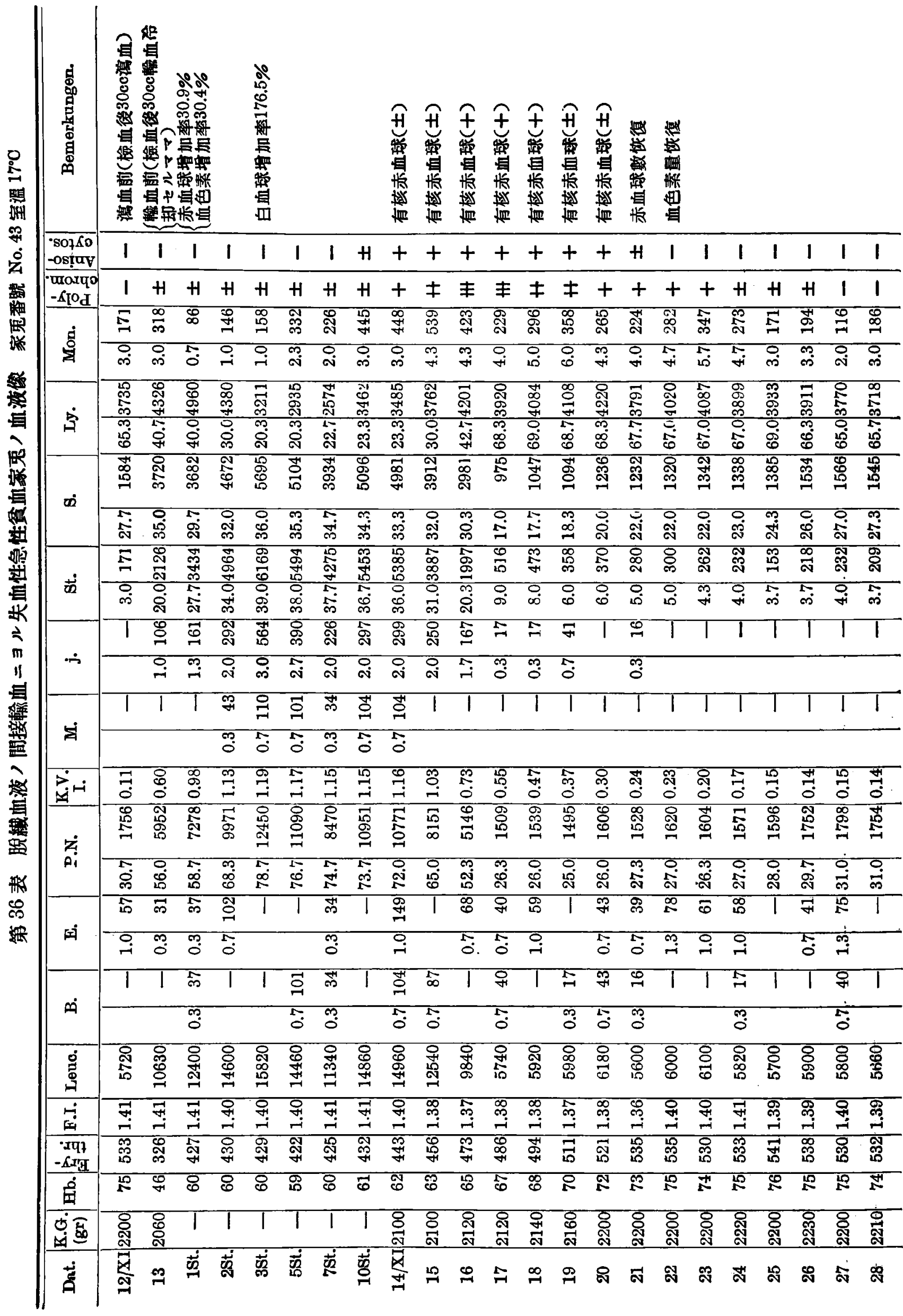




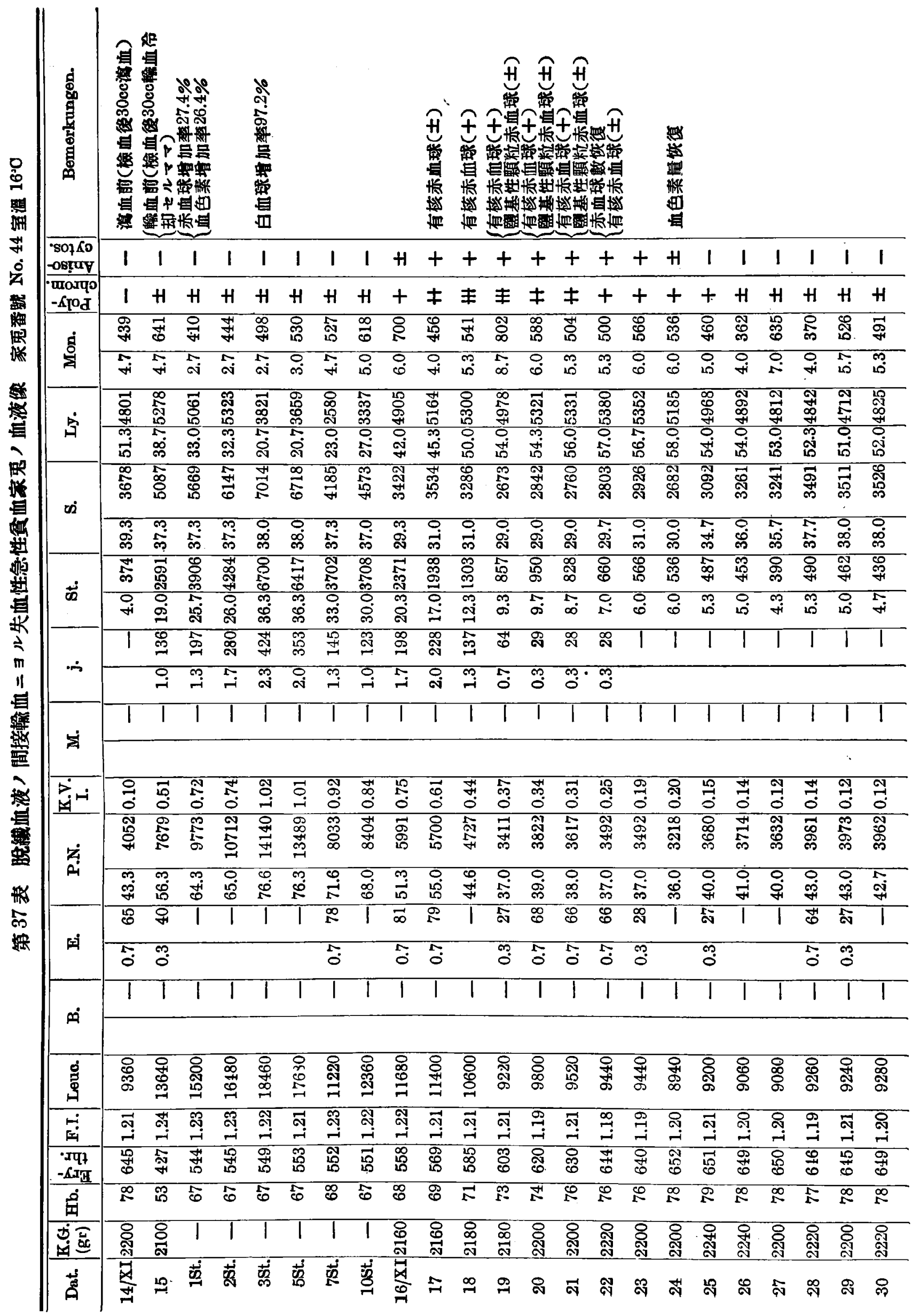




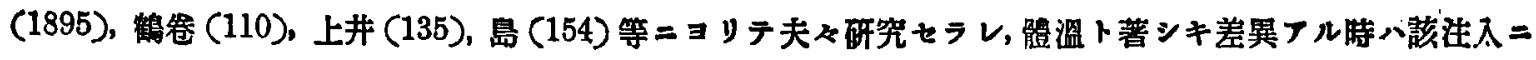

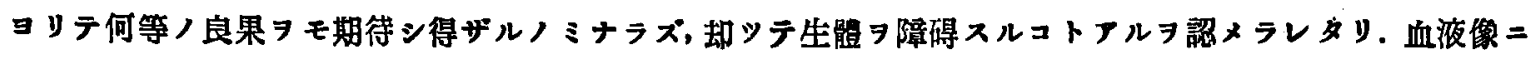

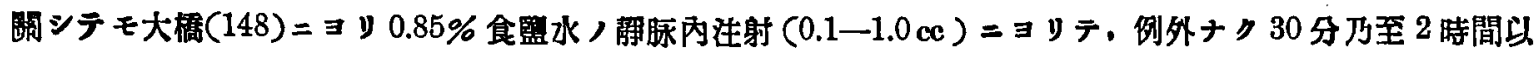

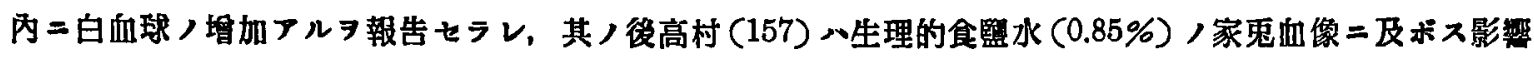

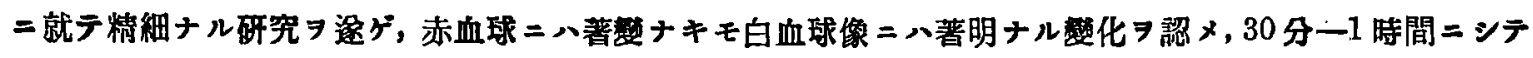

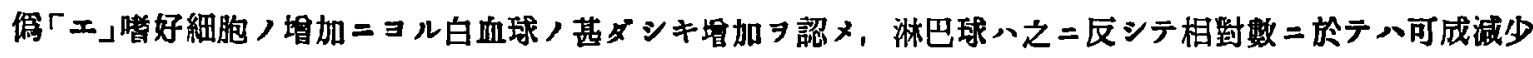

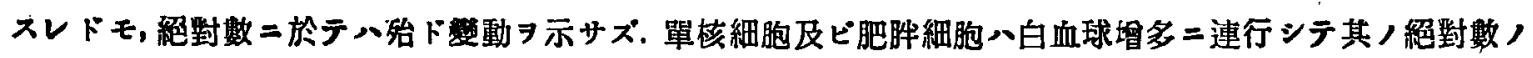

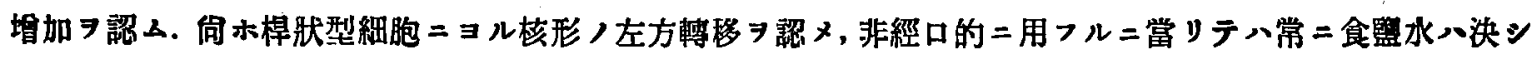

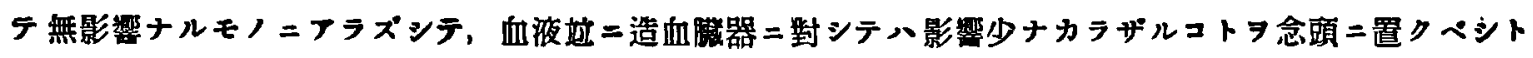
砉へリ.

大野 (150) 八赤血球二就テ研究シ，生理的食監水造入ニヨリテモ一時的二赤血球增多定

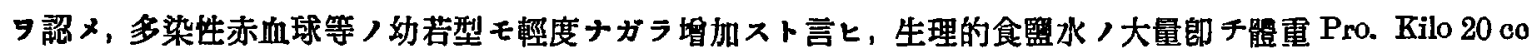

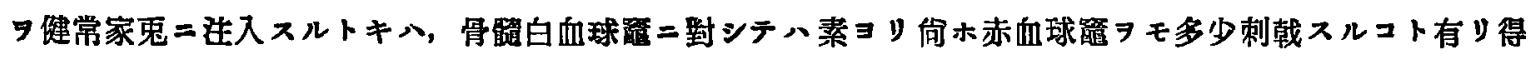

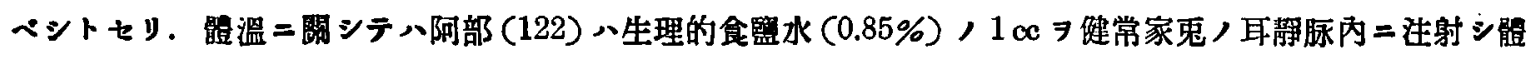
溫 $\ni$ 溫定セル二, 多少體溫八上䒜スルモ, 最大 3 分, 最小 1 分, 10 侧平均僅二 2 分强ニシテ, 其，影響スル 時間モ最長 1 時間, 最短 30 分，本均 40 分間二過ギズトセリ. 鈴木 $(155)$ ノ人二就テノ( $0.9 \%$ 生理的食監水

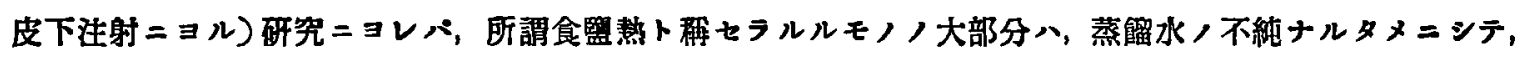
宽際體温上昇 $\exists$ 來スノ事實八疑ヘシト思考ストセり。

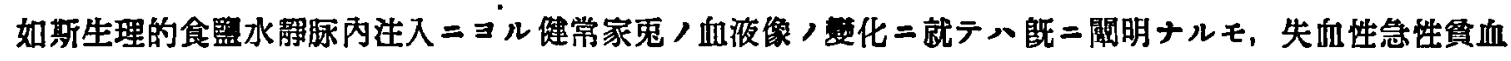

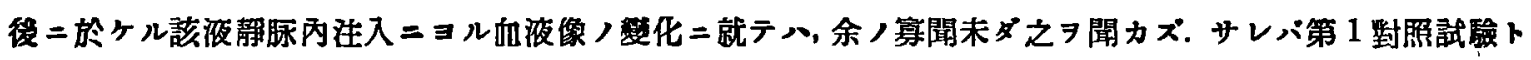

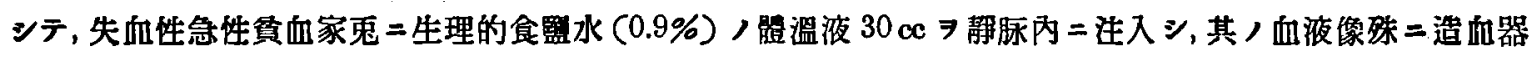
八血球再生機能二及ボス影響二就キテ考究セシ所以ナリ。

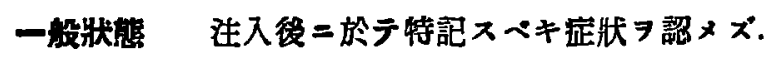

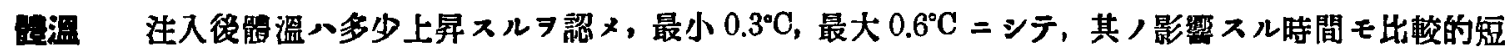
ク2ー3 時間二過ギザリキ.

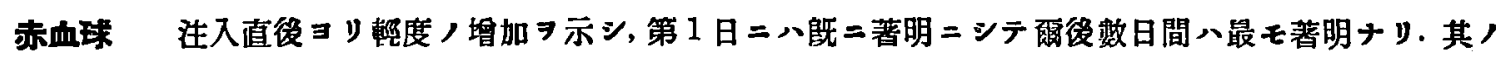

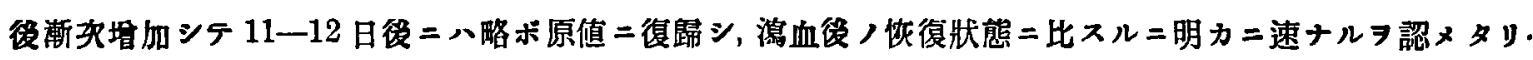
注入後數日間八多染性赤血球垃二大小不同㱏最モ著明ニシテ, 何木有㤥赤血球及ビ㿼基性顆䉼赤血球も出 現スルモ媵者ハ少シク遲レテ出現ス。

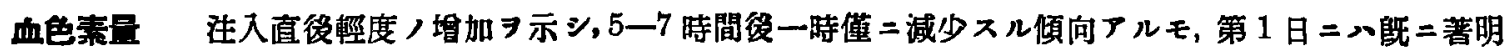

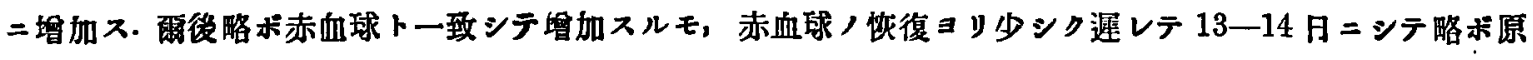
位二復舅 ス。

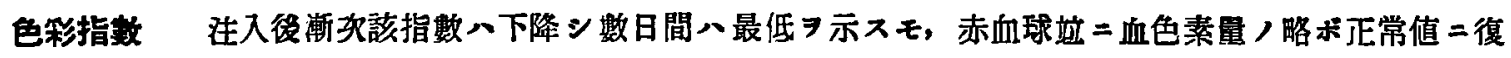
歸 スル頃, 本指數モ亦殆ド原位 $=$ 復鼠 ス。

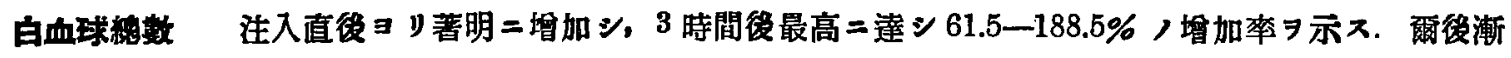

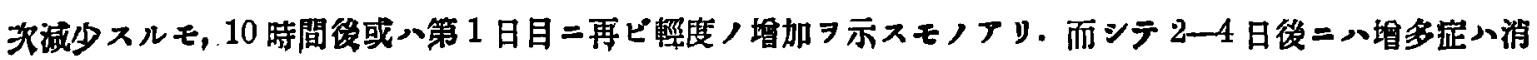




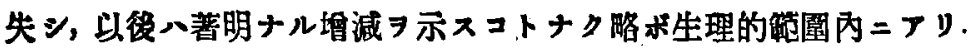

\section{各種白血球ノ相互的閶係}

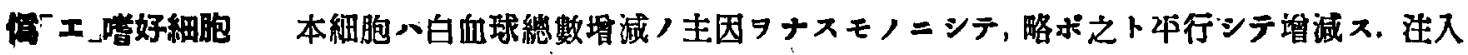

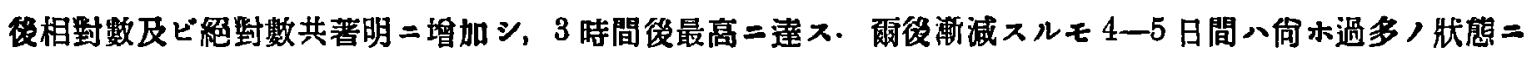
フリ. 级後八兩者共却シテ輕度ノ減少习示ス.

标形推移係数 栍入後著明二上昇シ，2-5 時間後二最大 $シ$ 示シ，以後比較的速二下降スルモ數日間八

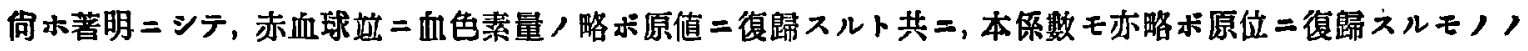

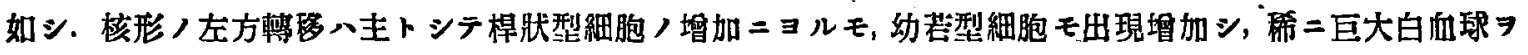
殭ムルコトナリ。

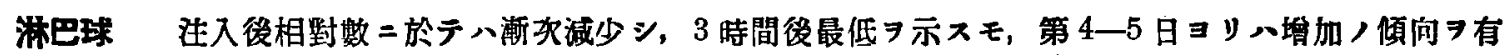
ス. 絶對數ニ於テハー時却ッテ增加シ, 5一10 時間後ニ八輕度ノ減少シ示スモ著明ナラズ. 而シテ早キ八䠶二 10 時周後 $=$ 多》八第 3-5 日二八增加シ，以後八全經過中輕度 $=$ 增多,狀態 7 示ス. 注入後數日間八Türk 氏刺戟型习姿く認メラル。

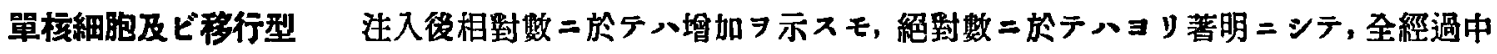
爾者共過多ノ狀㦔

「エ_嘹好細胞注入後相對數及ビ䋓對數共增加スルモノ/如キモ著明ナラズ.

肥㭌細胞一定セ儿變化 $\ni$ 認メ難シ。

第 2 項 枸株酸曹達ノ静脉內注入 $=ヨ ル$ 健康家鬼，

血液像，化培 $=$ 體溫

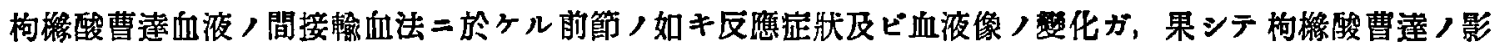

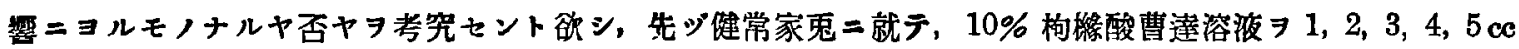

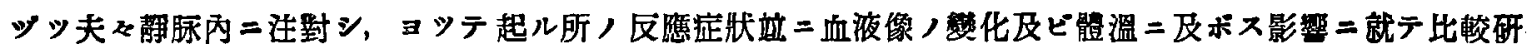
笔セり.

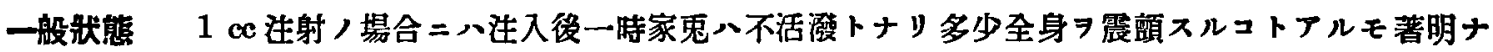

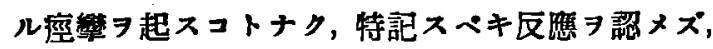

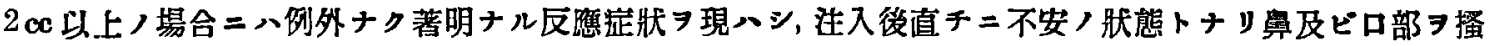

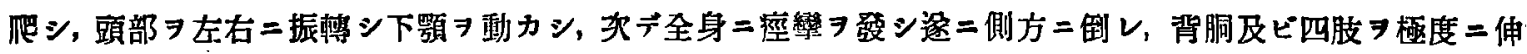

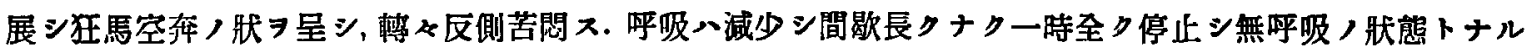

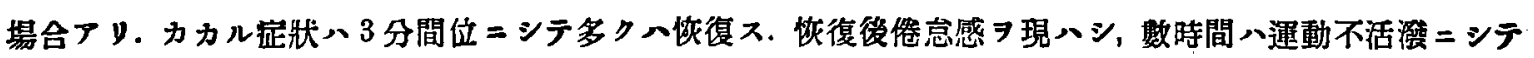

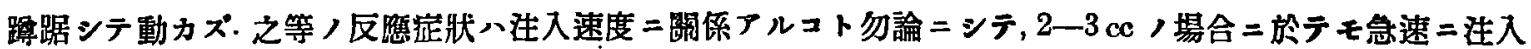
スル場合二八著明ナル㱏狀

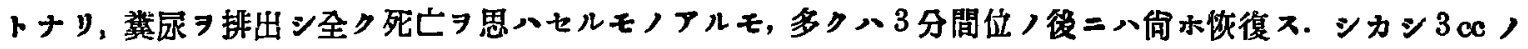

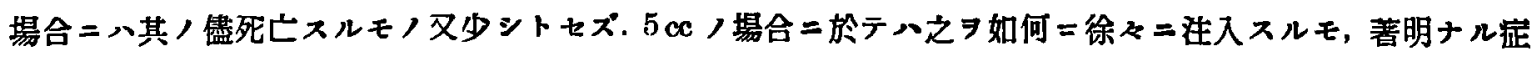

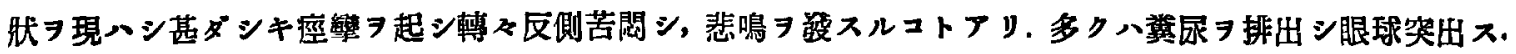

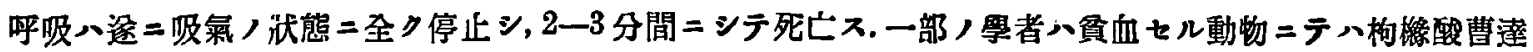

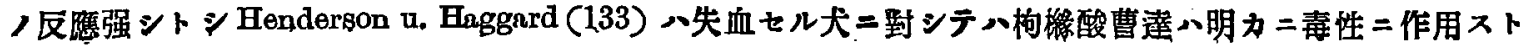




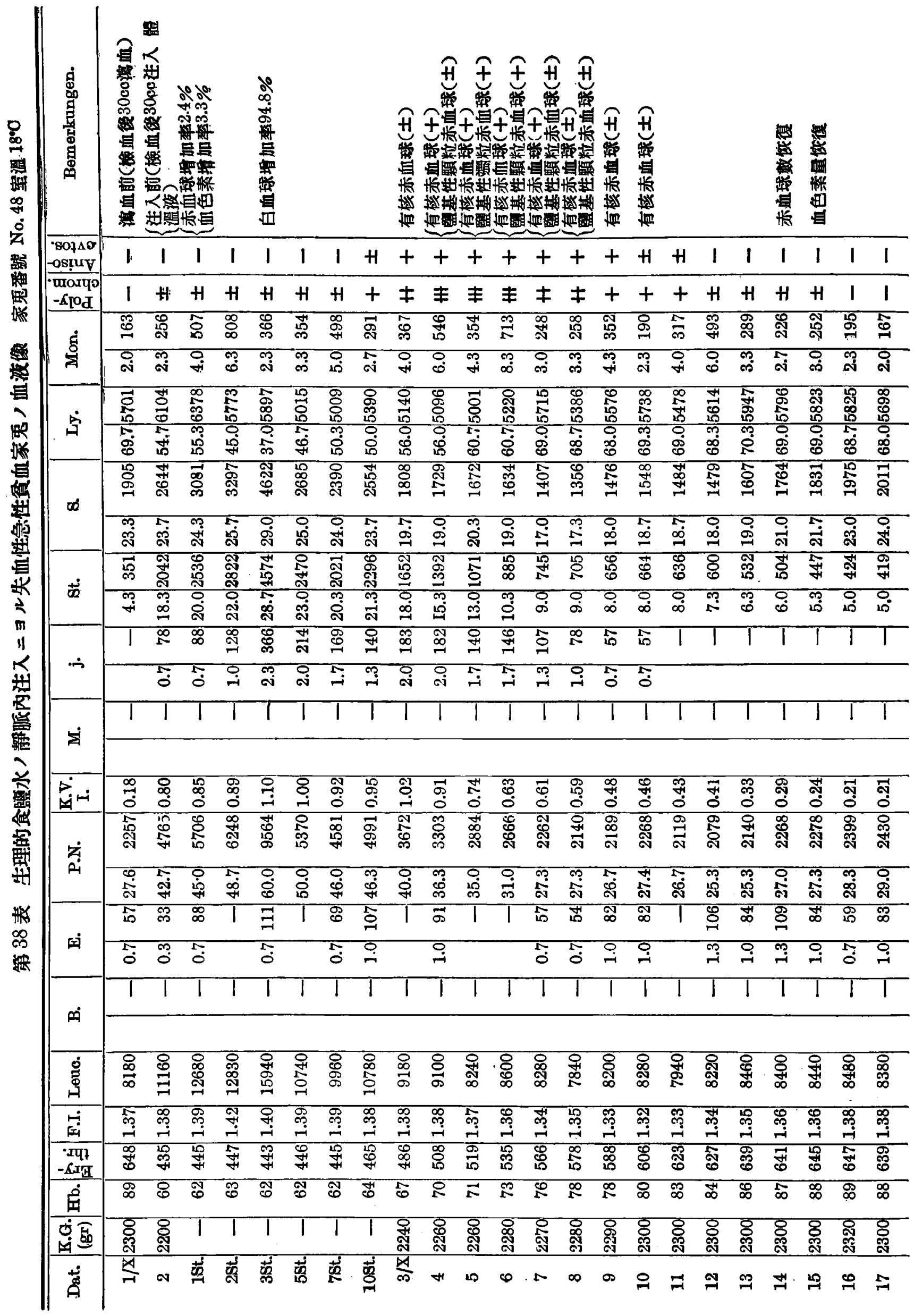




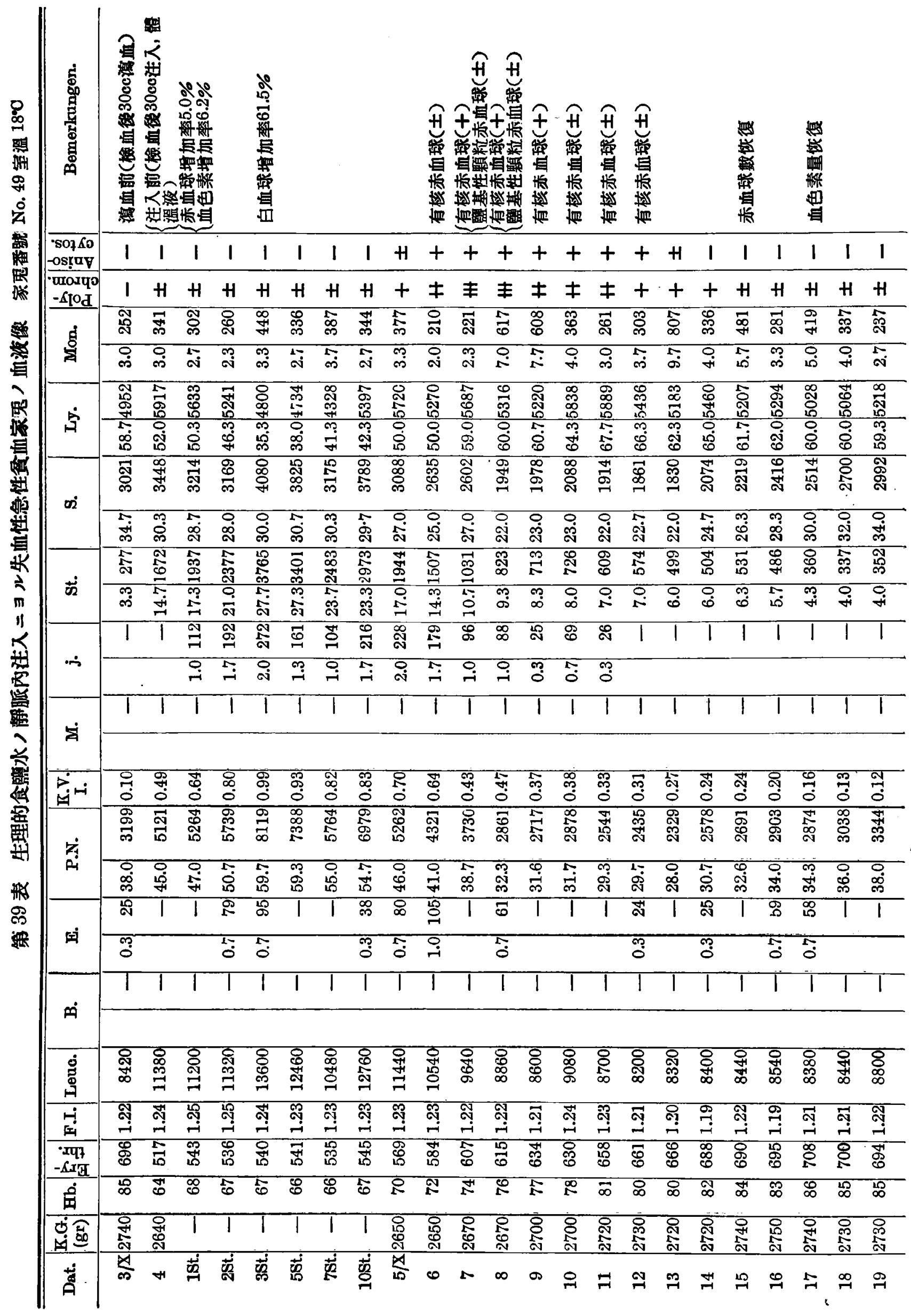




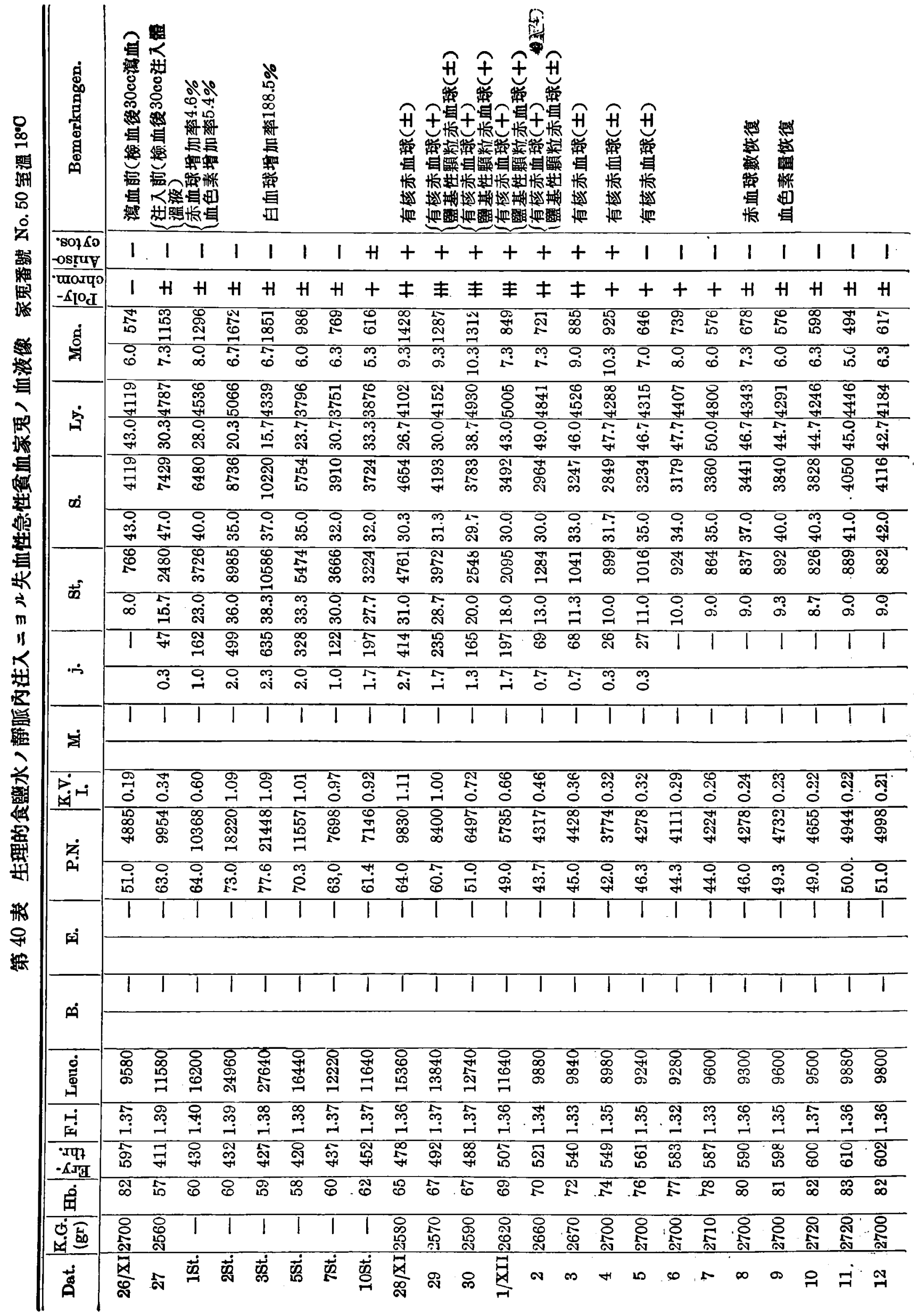




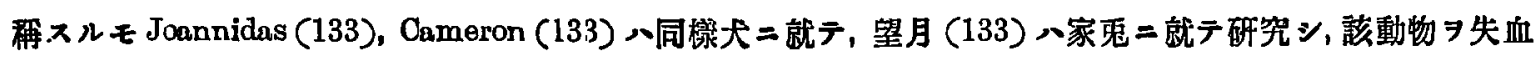

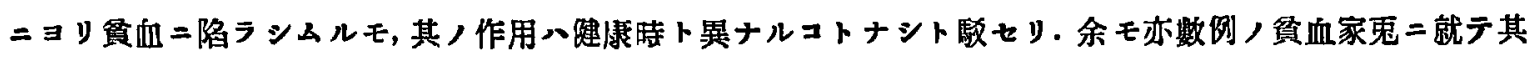
，作用，健康時二於ろルト比較セルニ，兩者，間二於テ著明ナル差異アルヨ認メ得ザリキ.サレパ余モ望月

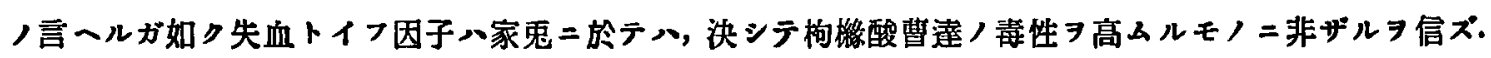

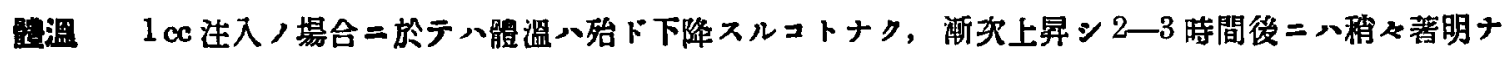

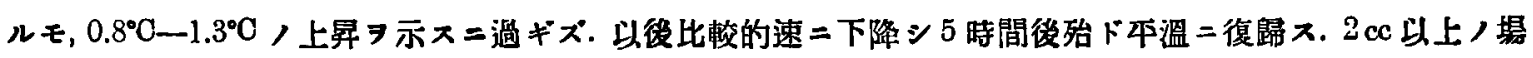
合二於テハー時明カ二下降シ $1-2$ 時間八下降ス. 多クハ $0.5^{\circ} \mathrm{C}-0.8^{\circ} \mathrm{C}$ ，下降 $ヨ$ 示シ甚ダシキ場合二メ $1^{\circ} \mathrm{C}$

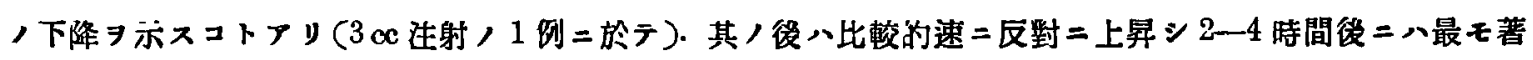

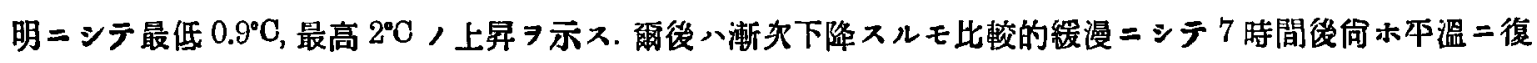
歸セザルモノ多シ.

赤血球 泩入後著明ナル堦減ヨ示サザルモ，大量注射ノ場合二八輕度二隇少シ且多染性赤血球，增加 ヨ認ムルコ1アリ.

血色素量赤血球同樣著悠ナキモ大量泩射ノ場合二八輕度二減少ス。

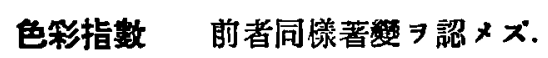

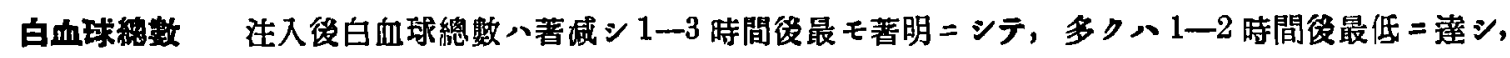

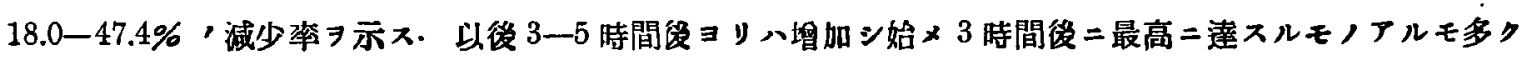
5-7 時間後 $=$ 最高 $=$ 達シ，30.6-180.9\%，增加率习示ス. $4 \mathrm{cc}$ 注入，場合二八最モ著明ナリ．白血球，

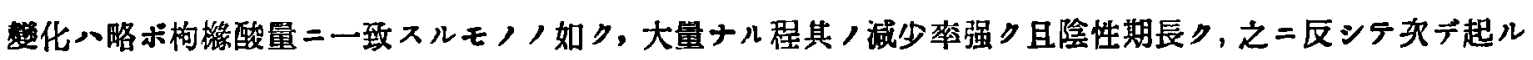

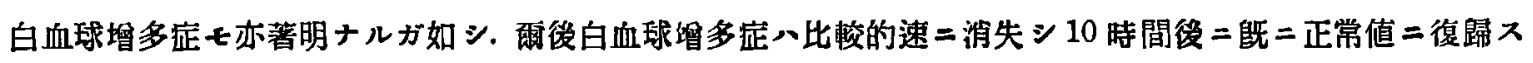
ルモノアルモ, 多クハ第 $1-3$ 日ニシテ正常值二復歸ス.

\section{各種白血球ノ相互的關係}

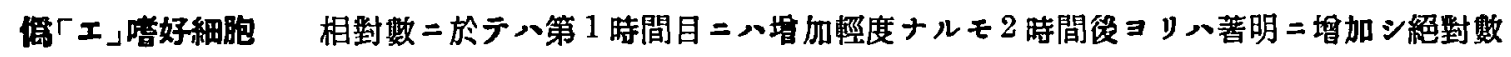

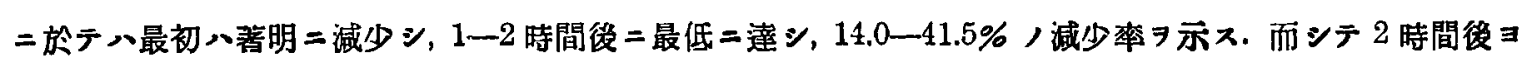

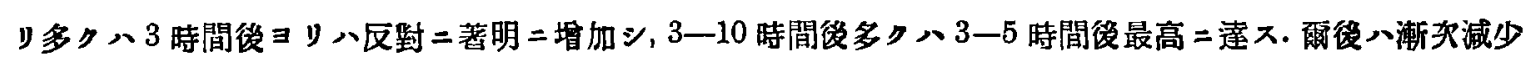

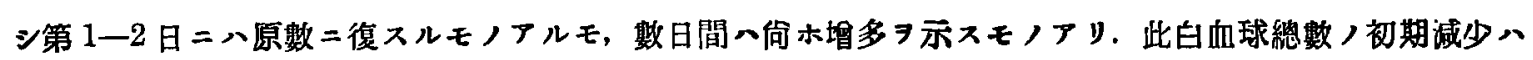

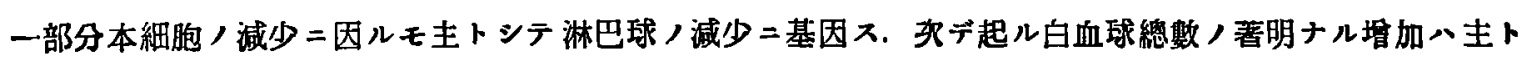

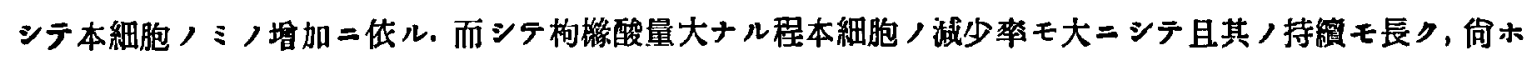
次デ起ル增加モ亦著明ナルガ如シ.

核形推移係數注入後本俰數八著明二上昇シ, 白血球總數剒加ノ最高時二於テ亦最高

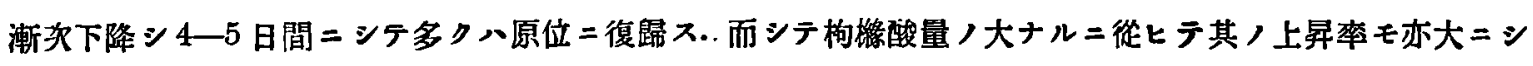

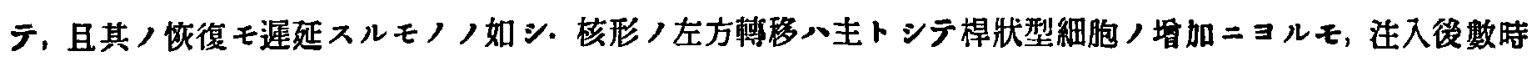

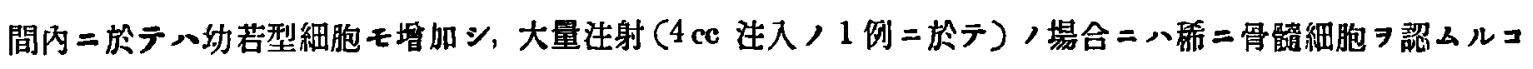
トフע.

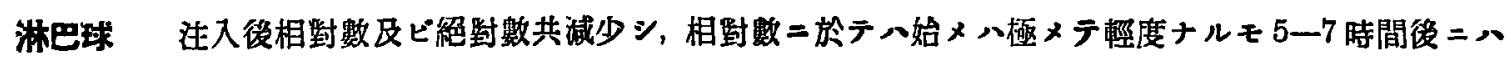

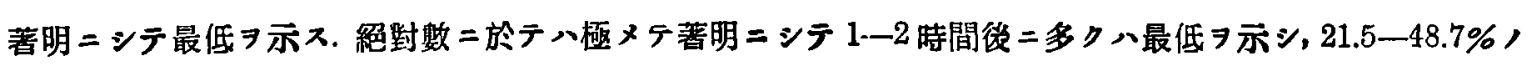

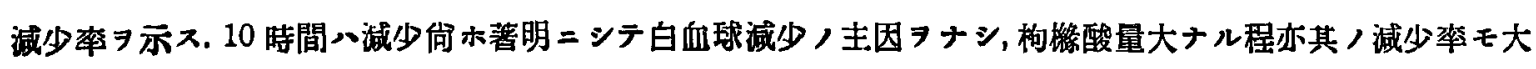



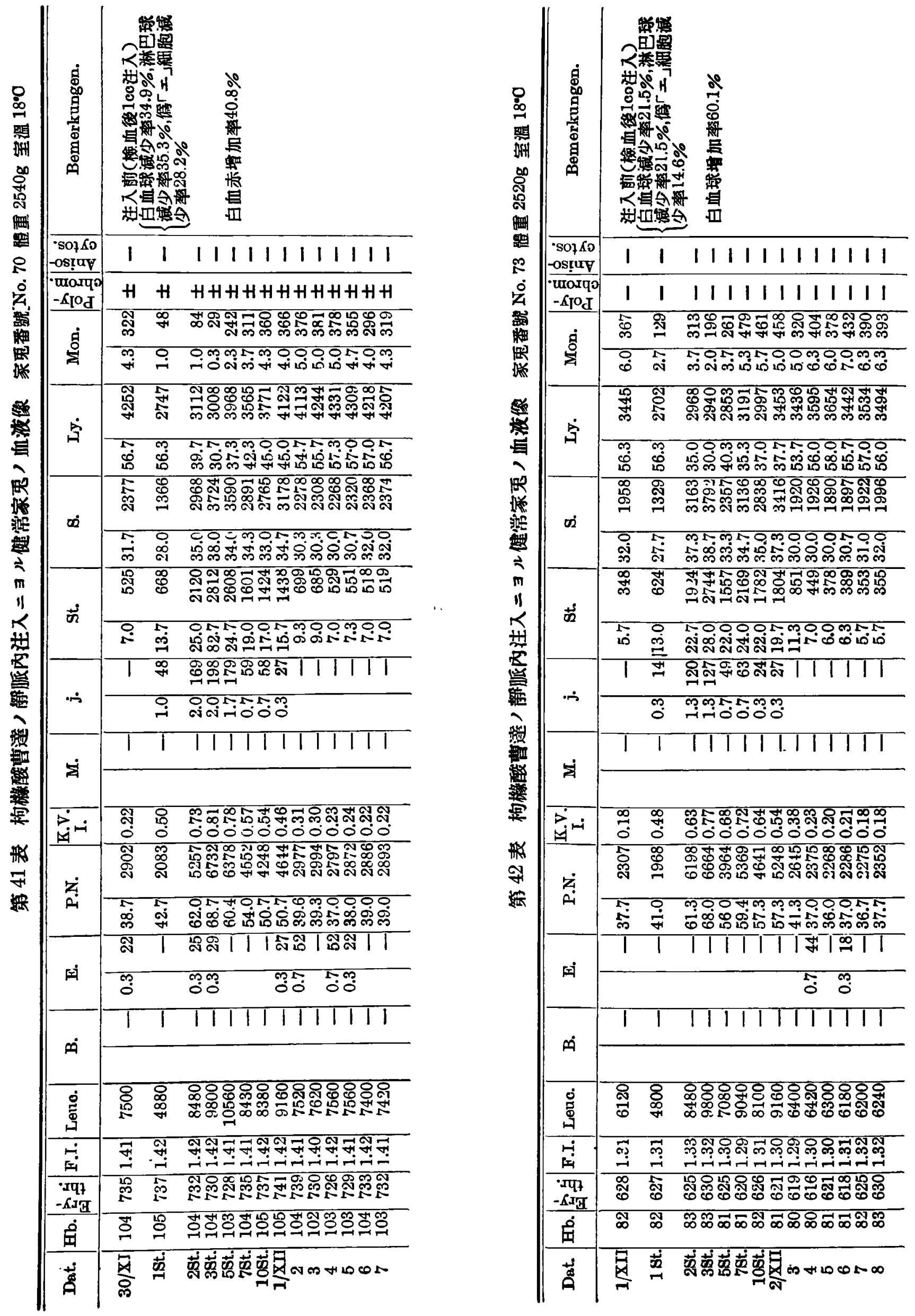

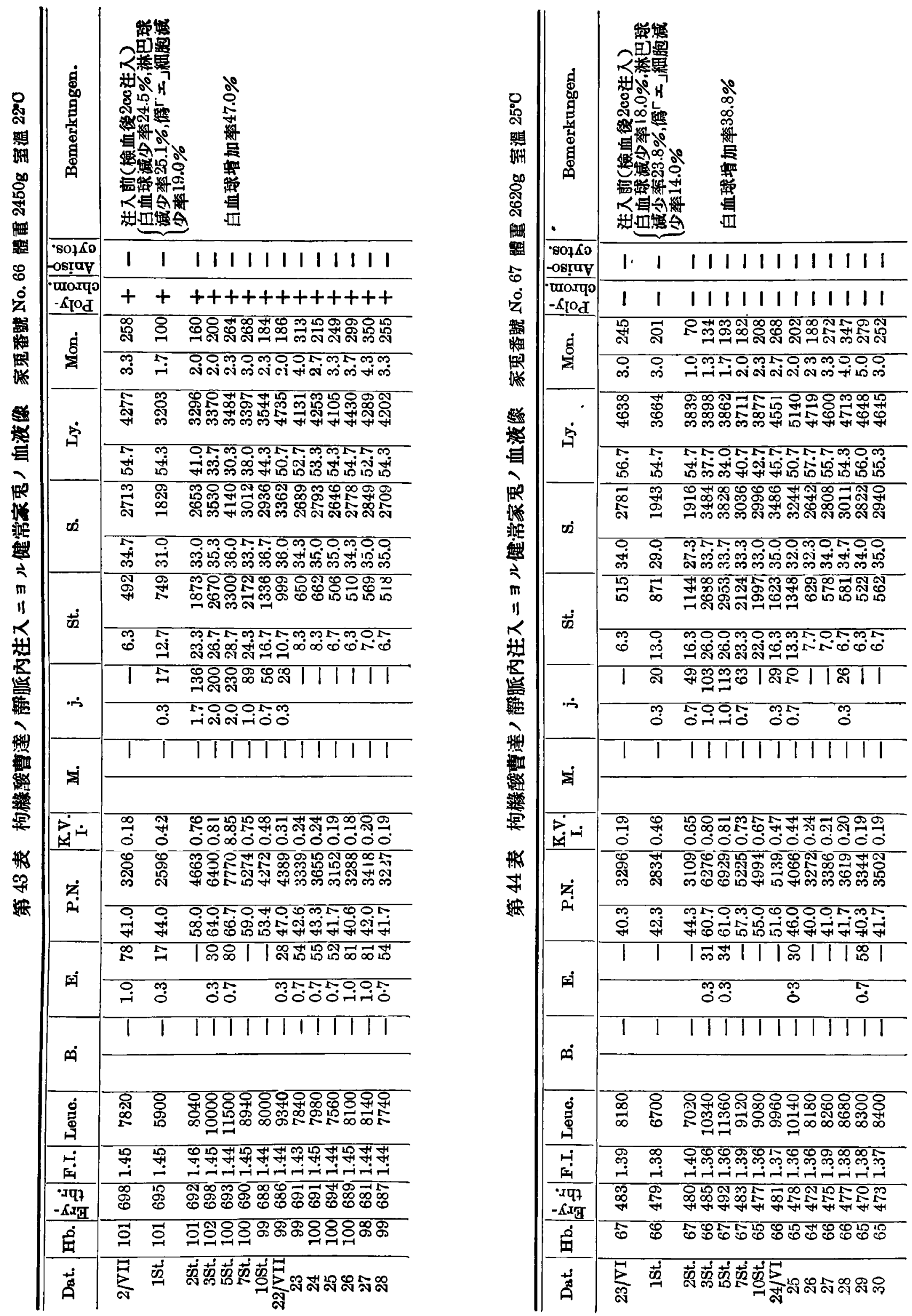

131. 

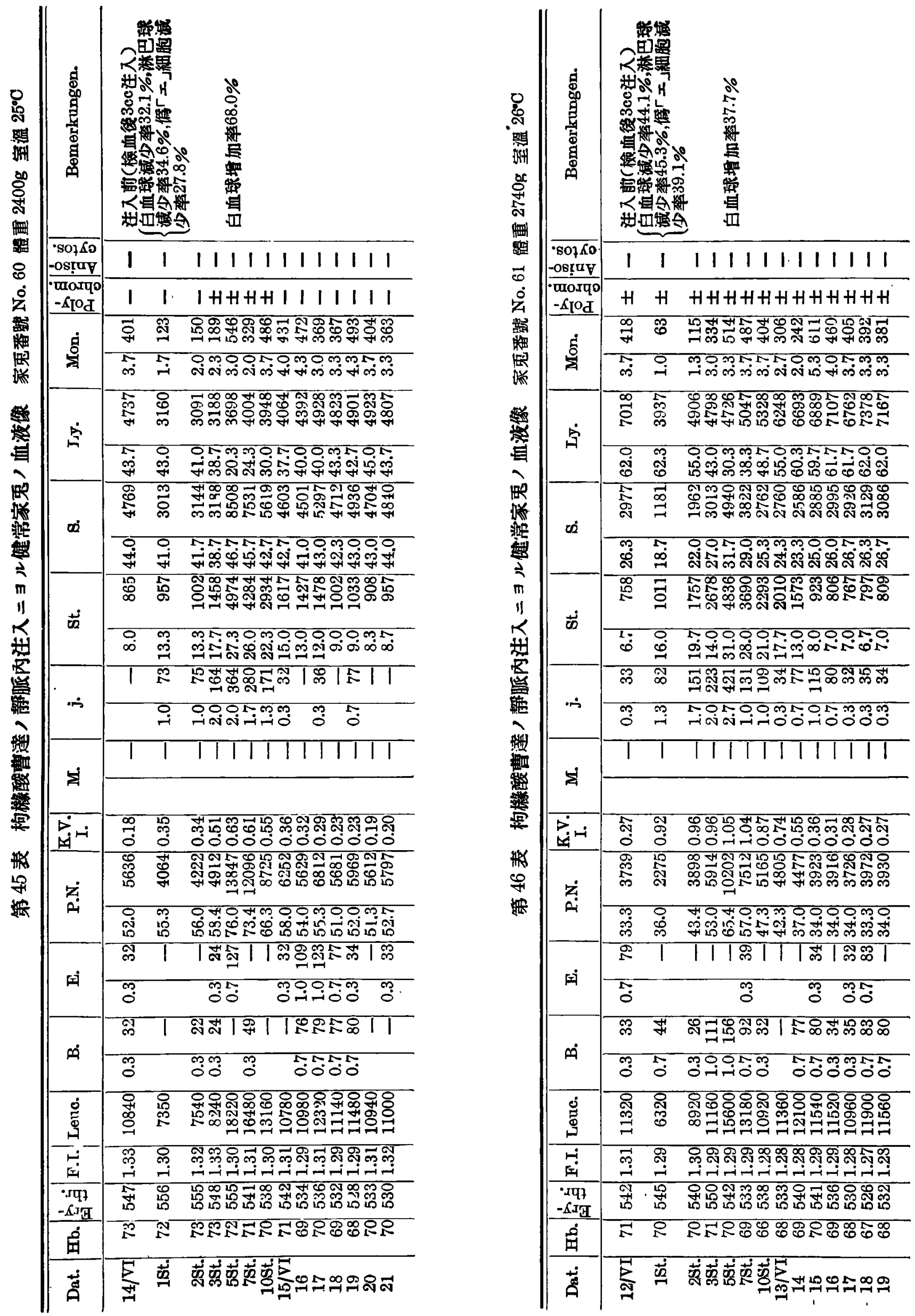

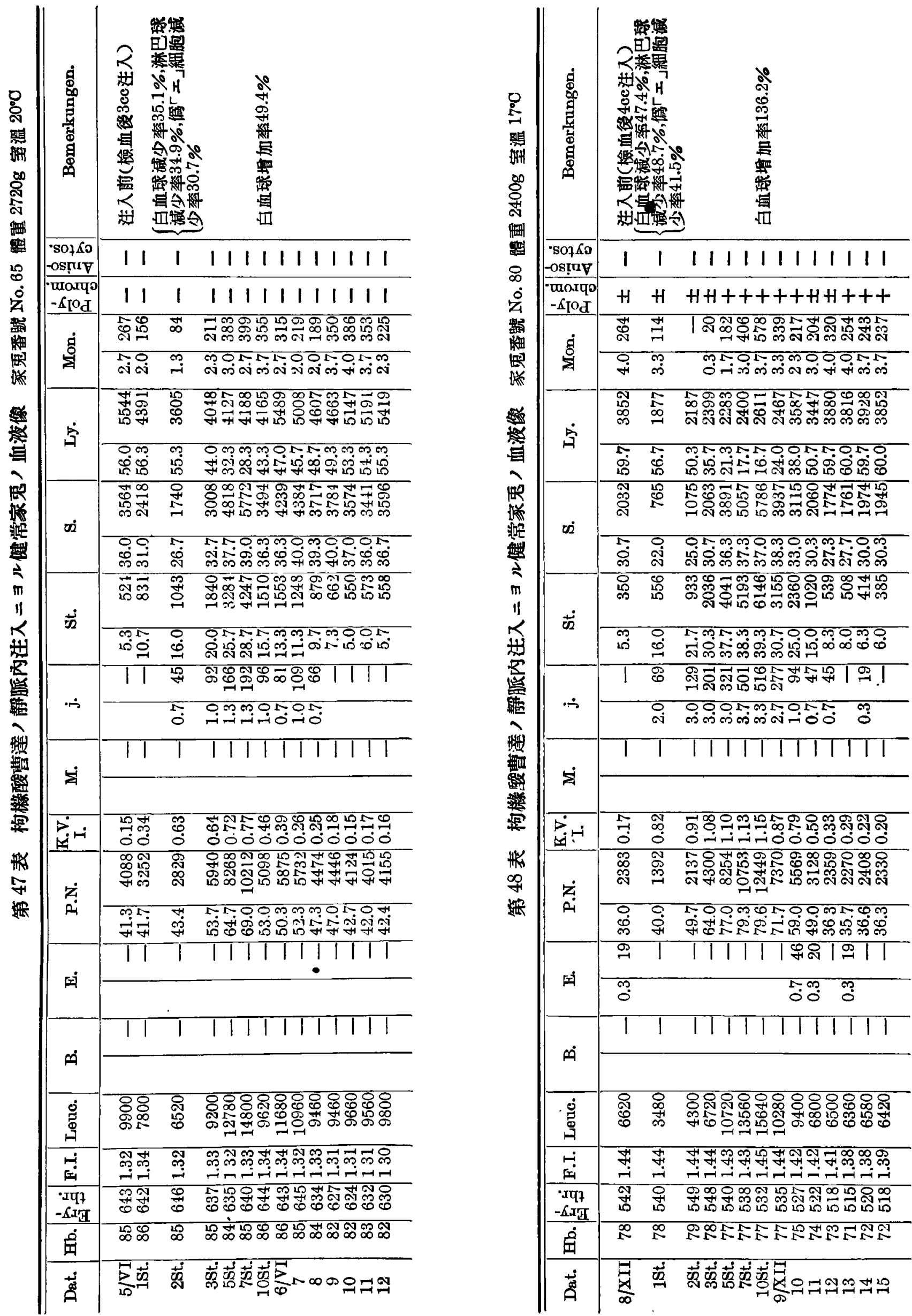
ス

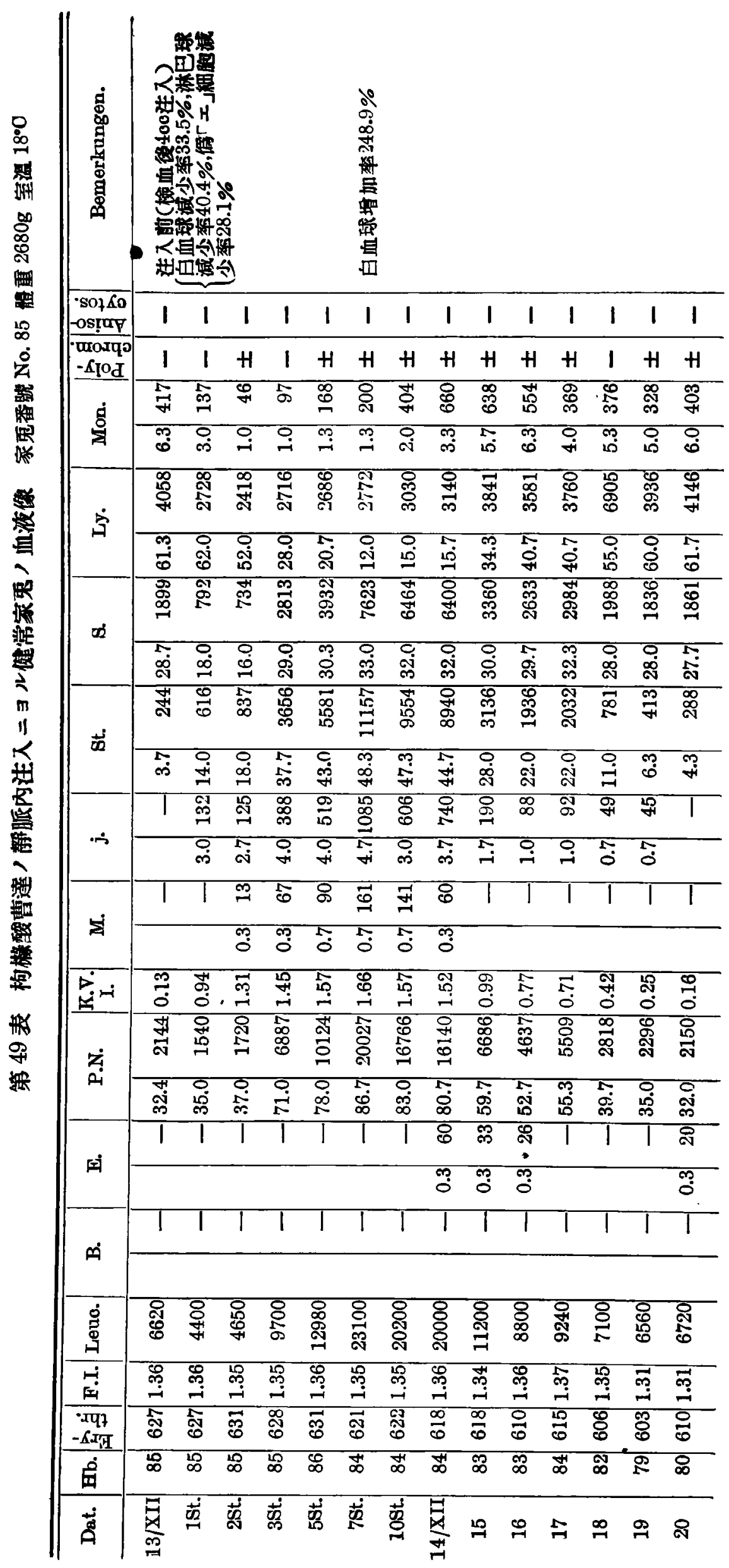




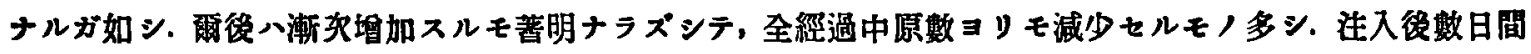
メTürk 氏刺戟型ヨ諰ムルコトフリ。

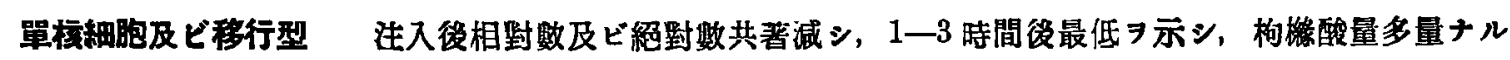

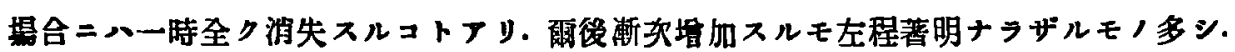

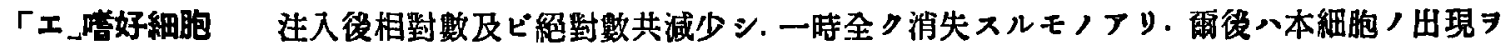

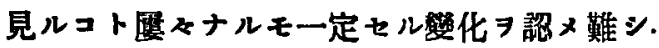

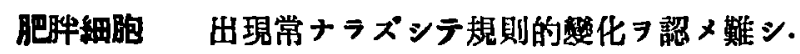

第 3 項 血球浮游液，静脉內注入 $=$ ル健常家鬼，

血液像, 變化站 $=$ 顝溫

血球浮游夜

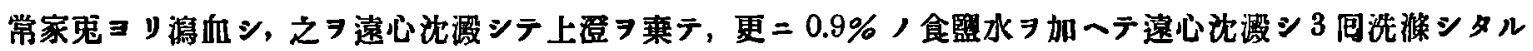

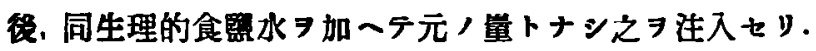

一般狀態注入後一般狀態二認ムべキ应狀

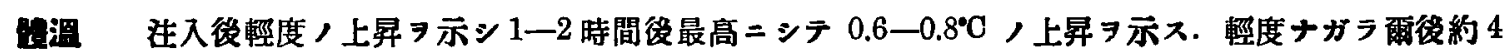
時間ハ何木平溫 コり稍々高シ。

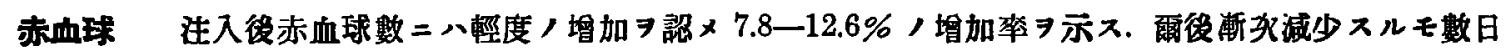

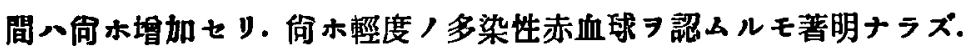

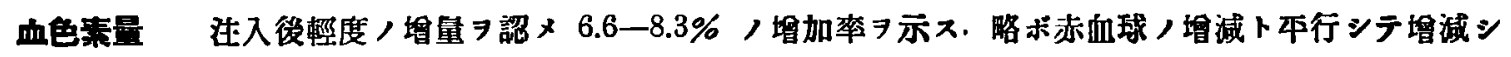
爾後渐城スルモ数日間八向木增星 7 示セリ。

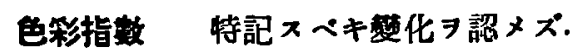

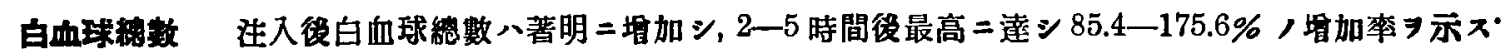
爾後渐次減少スルモ第 1 日目二八向木過多, 狀意

\section{各種白血球ノ相互的的保}

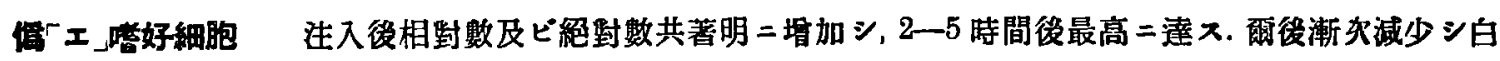
血球增多症，消失卜共二本細胞／堵多 $习$ 亦消失ス.

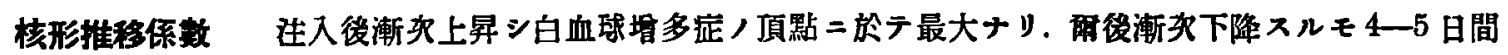

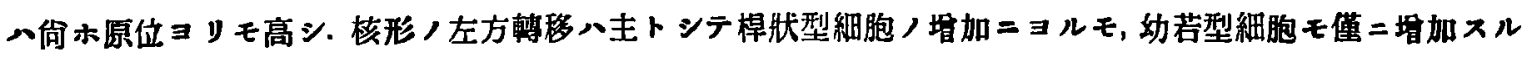
裙人.

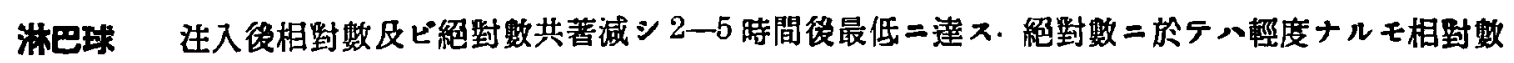

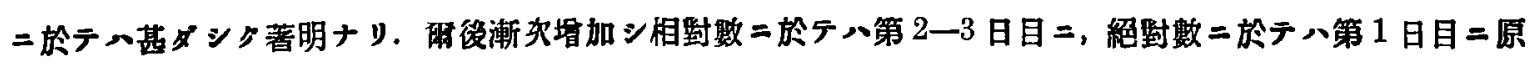

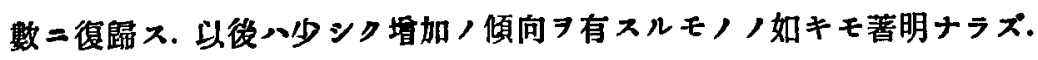

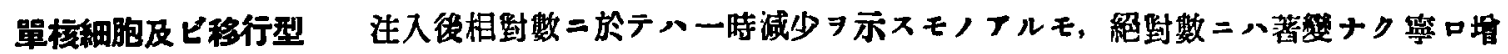
加八傾向习示ス.

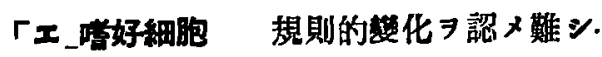

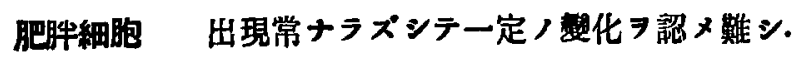



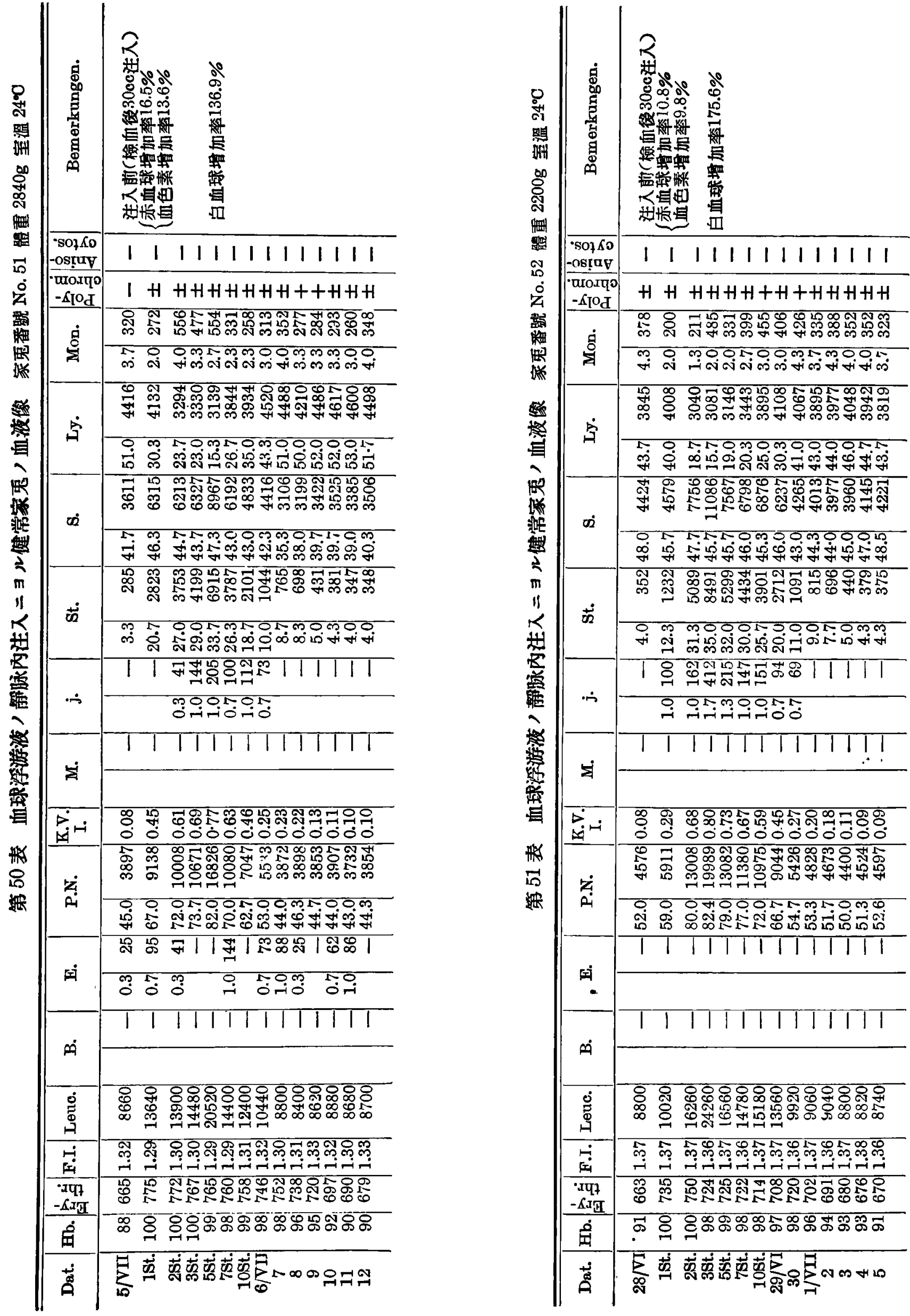


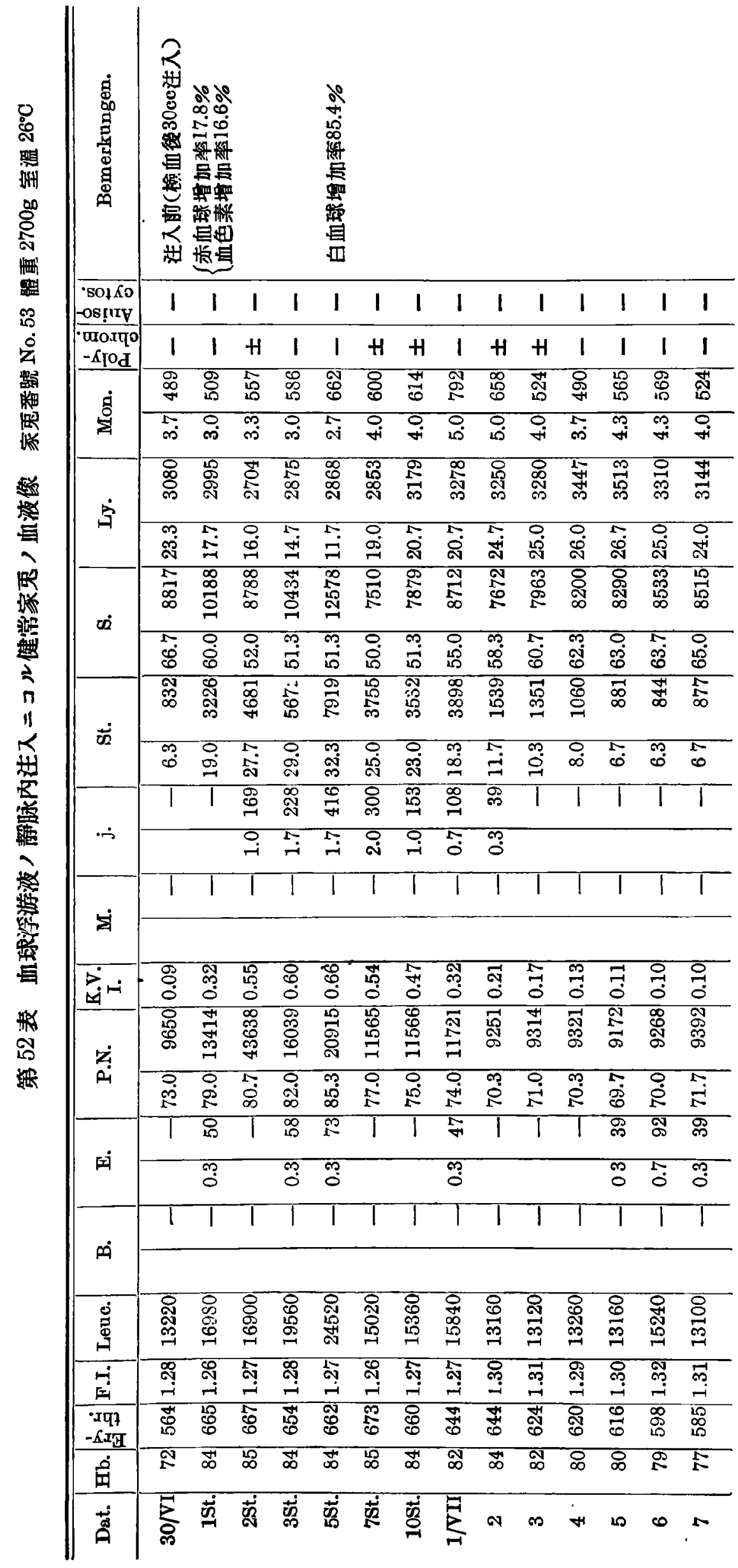


第 4 項 健常家鬼血清 /静脉內注入 $=\Xi$ ル健常家鬼

血液像ノ紮化站二體温

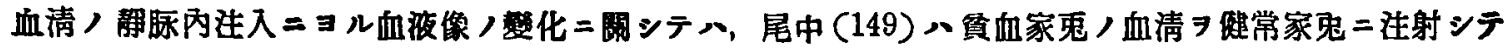

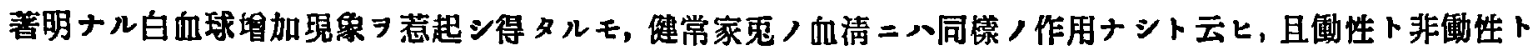
ノ間二八差異ナシト云ーリ. 大橋 (148)八健常家婜，血清

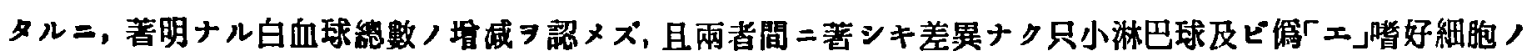

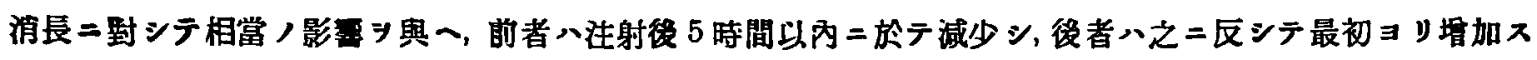

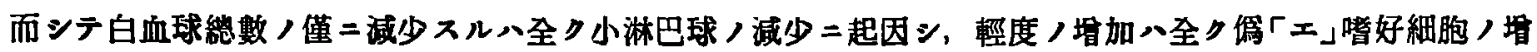
加二起因ストセע.

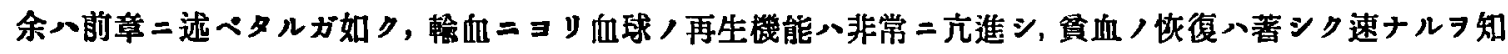

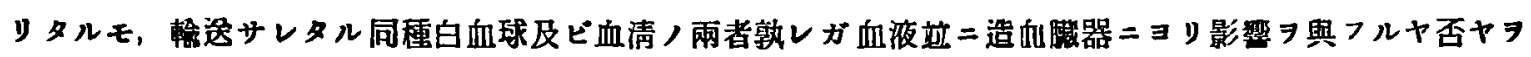

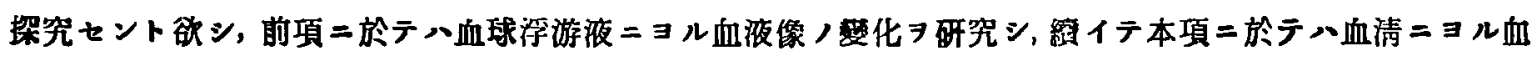

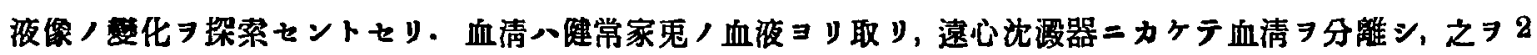

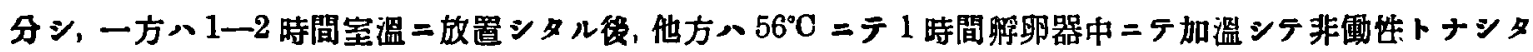

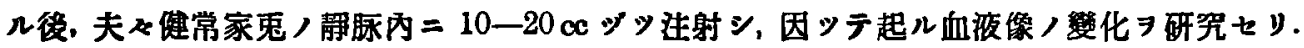

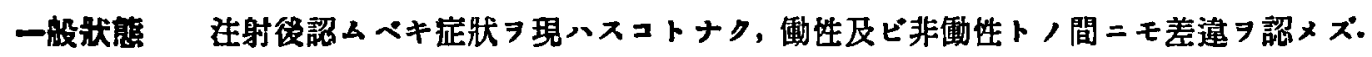

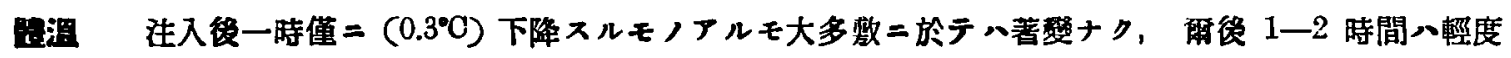

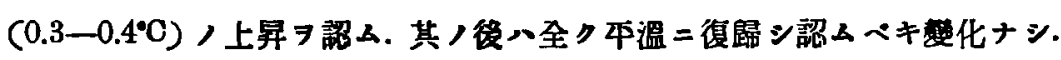

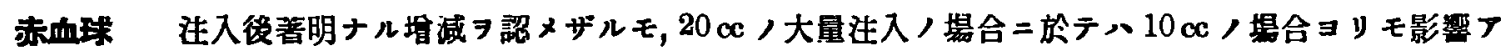

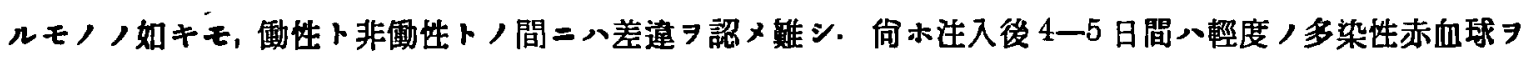
詔ムルモノ，如キモ亦著明ナラズ。

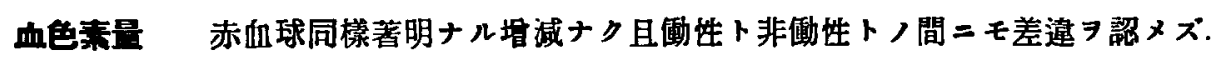

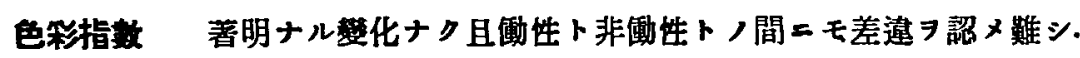

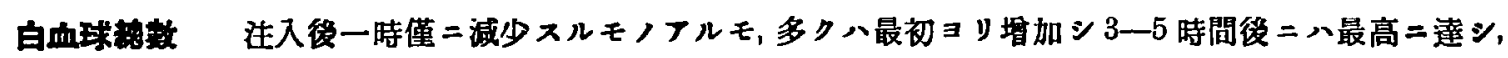

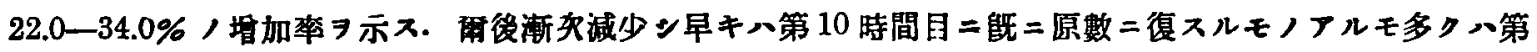

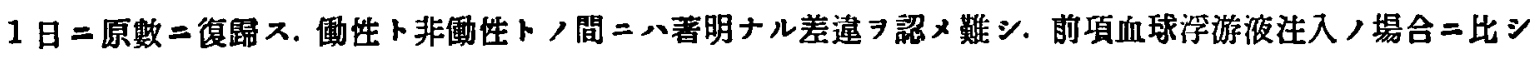

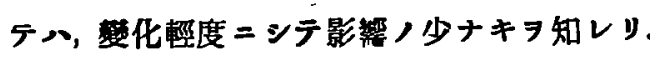

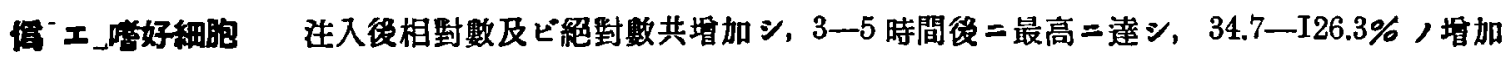

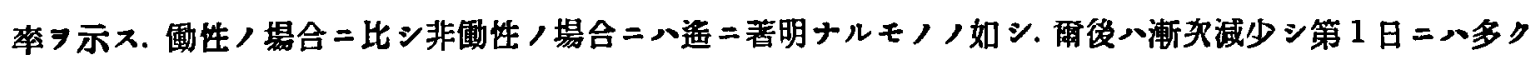
八原數二復䦠

核形推移保数注入後著明二上昇シ, 白血球增多症ノ最高値二於テ本俰數モ亦最高位

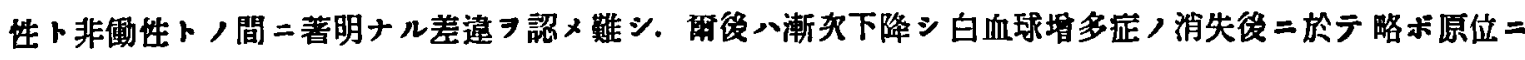

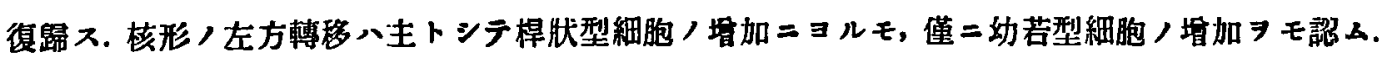

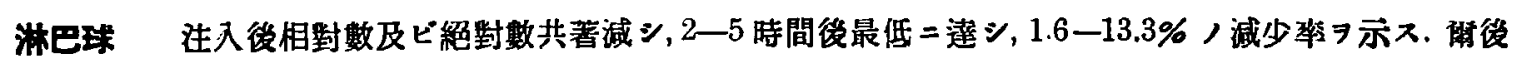
渐次坦加シ早キハ 10 時間後既二原數二復スルモノアルモ、多クハ第 1 日二原數二復歸ス. 而シテ働性ノ場

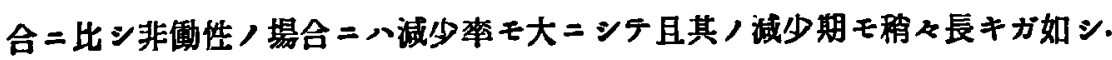



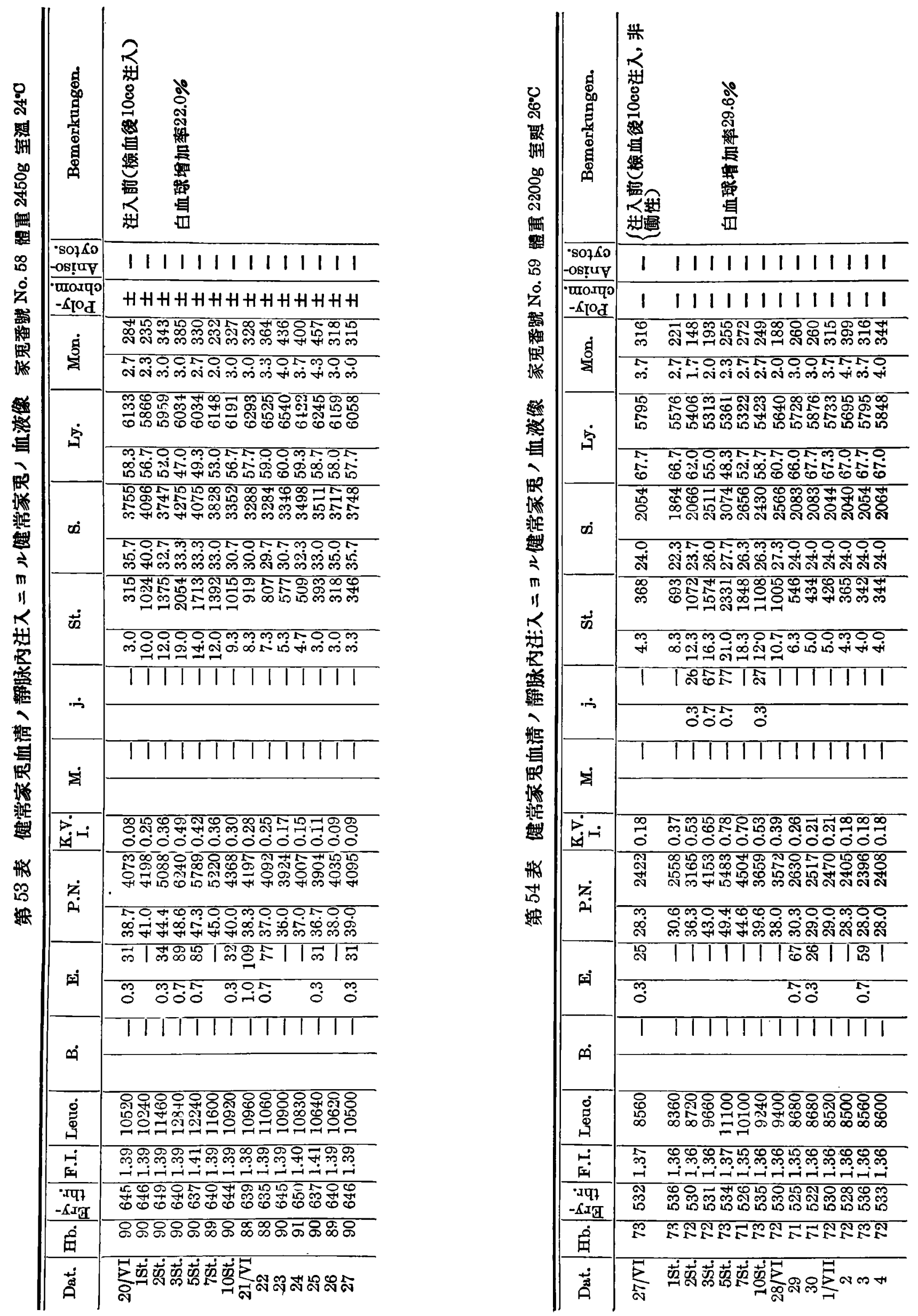


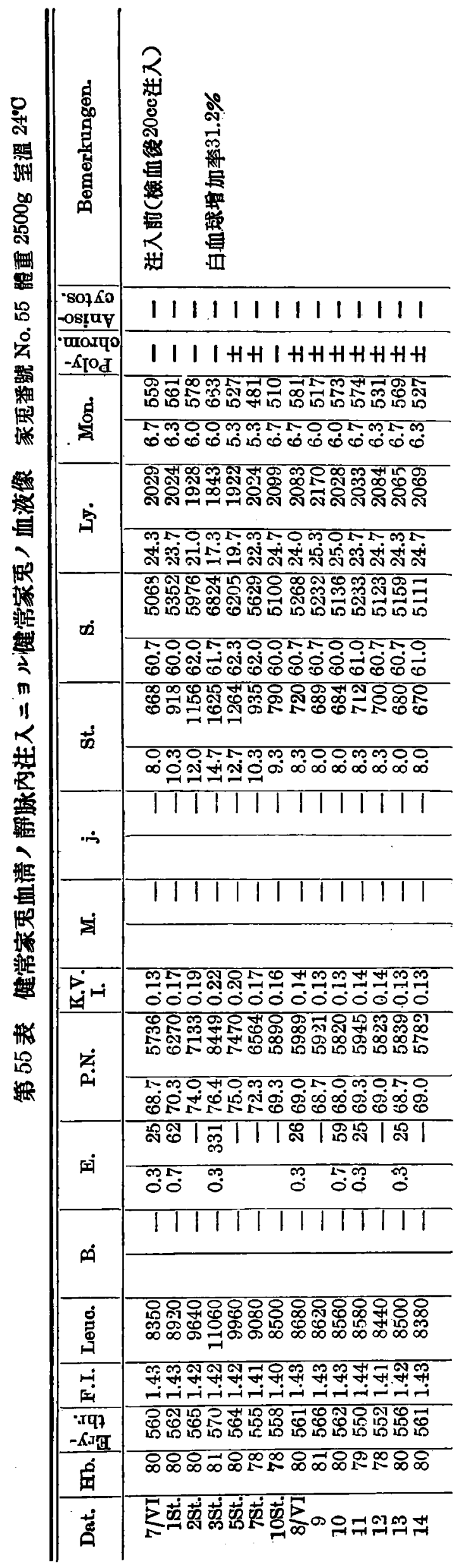




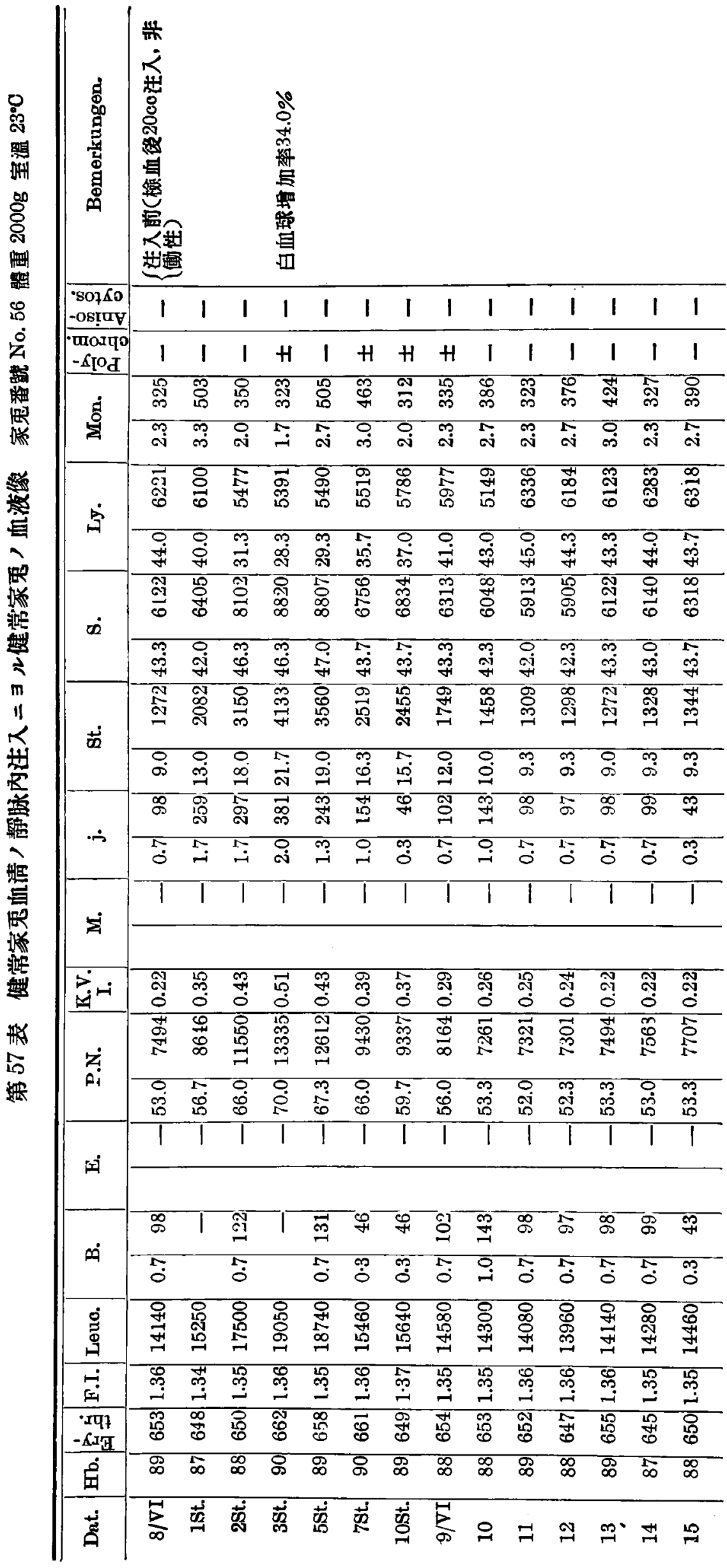




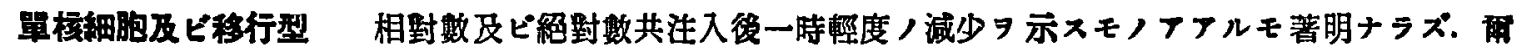

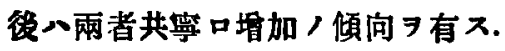

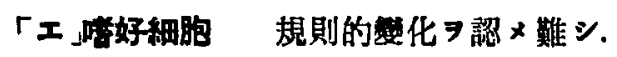

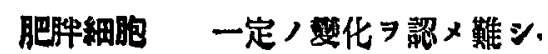

\section{第 4 草 全實驗成綪ノ總括及ヒ考按}

健常家鬼ノ血液像二就キテハ，大體先淮諸學者ノ成績ト大差ナシ．但シ余ハ家鬼ニテモ亦血

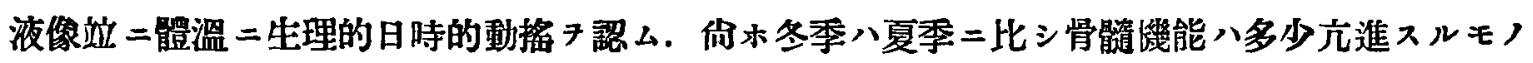

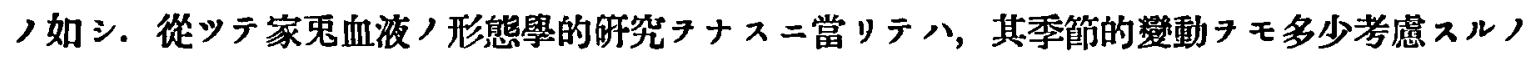

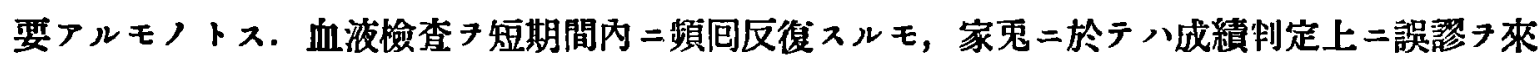
スペキ程度ノ變化ナキチ知レリ。

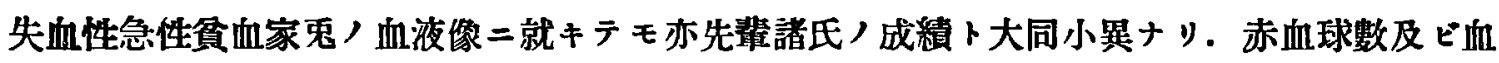
色素量 滨血後既二第 1 時間目 =於テ著明二減少シ，後者八減少度八前者二比シテ甚ダシク從

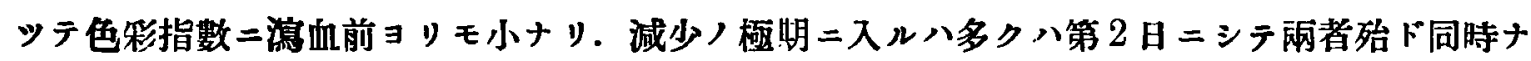
ルモ，此時期ニテハ赤血球ノ減少度八血色素量二比シテ著明ナリ．從ッテ此時期ノ色彩指數八 他ノ敦レョリモ大ナリ．兩者共渇血第 3-4 日頃ヨリ急速二增加シ，赤血球數ハ14-19 日ニシ テ略ボ原數二復歸スルモ，血色素量ノ恢復八迤二避延ス. 白血球數八瀉血後著明二塔加シ，井

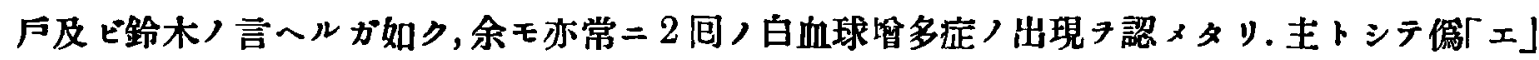
嗜好細胞ノ坦加二基因シ，核形推移保數モ亦著明二上昇ス。第 2 回白血球坦多症八 5-11 日多 クハ6-8日ニシテ全ク消失ス.

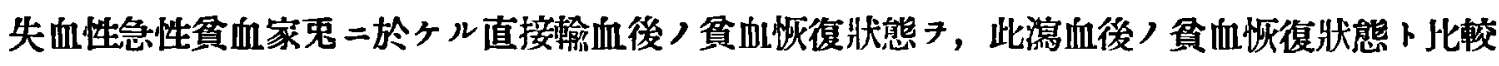

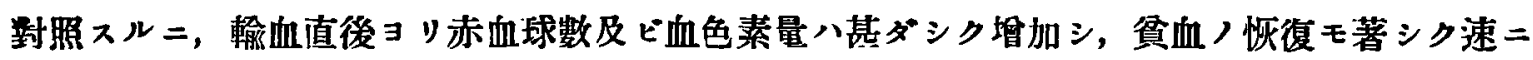

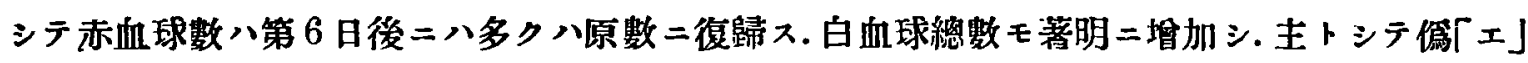

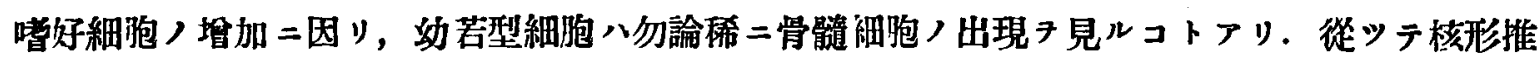
移係數八著明二上昇シ, Schilling >所謂再生推移性血液像 (regenerative Verschiebung des

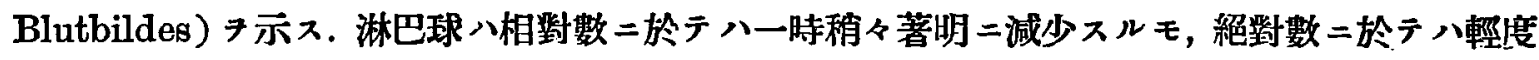
ニシテ後ニハ兩者共稍々著明二堆加シ，屡々Türk 氏刺戟型キモ認ム，單核細胞及ビ移行型モ

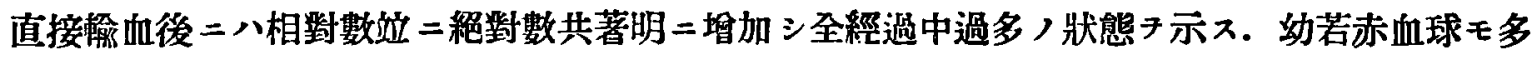

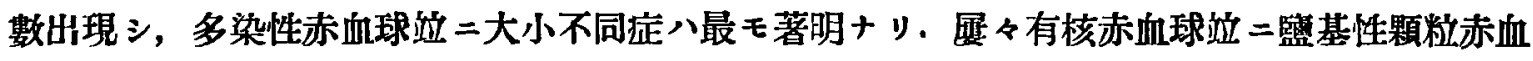

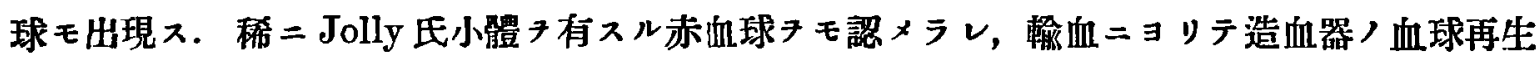
僟能ハ著シク亢淮スルコトチ知リ得タリ。

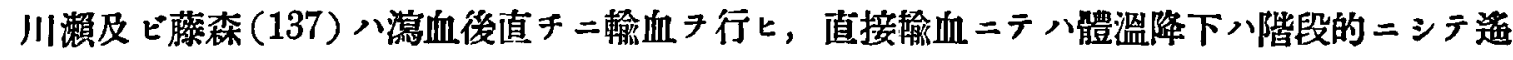
二緩漫ナルカ, 或ハ一時輕度二下降シ再ビ上昇シテ正規二近デクト言へルモ, 余ノ筫驗例二於 ケルガ如ク澺血後第 1 日目二輸血ヨ行フ場合ニハ, 䯤溫ノ下降ハ殆ドナク却ッテー時与.昇スル 
ア証メタリ. 此上昇度モ多ク八輕度ニシテ $1.0^{\circ} \mathrm{C}$ 內外二此マリ且比較的速二下降シ 5 時間後二 八全ク本溫二復蹛ス．反應应狀二就キテモ先進諸藇者ト同樣余モ亦殆ド之フ認メズ，サレバ失 血性急性貧血ノ恹復二八直接輸血法》最モ合理的ノ良法ナルタ知レッ.

构䅂酸曹達血液》間接輸血法八直接輸血法二比スル二, 貧血ノ恢復モ稍々迤延シ赤血球數モ 多クハ8 日ニシテ原數二復歸ス. 幼若赤血球ノ出現二就キテハ著明ナル差違き認メ難キモ, 白

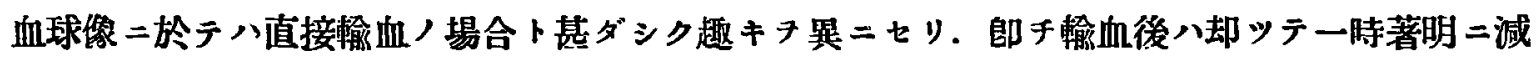
少シ， $1-3$ 時閒後多クハ 2 時間後二最低ョ示ス. 而シテ其ノ後・早キハ 3 時間後ヨリ多クハ 5

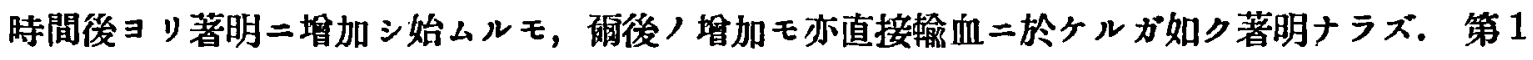

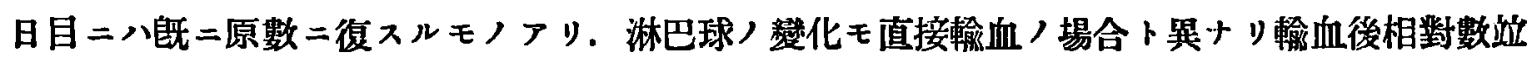

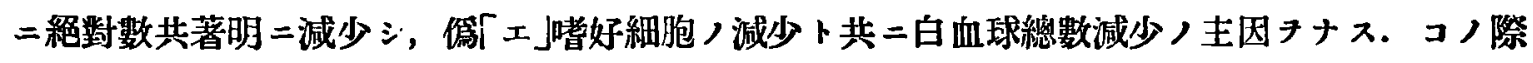

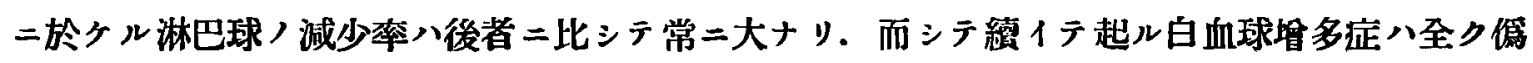

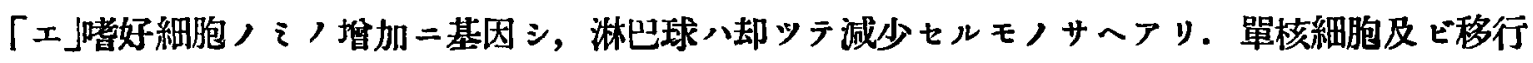
型モ相對數的二絕對數トモ輸血後一時著明二減少シ, 絕對數つ減少度ハョリ甚ダシク, 爾後兩 者共剒加スルモ直接輸血二見ルガ如ク著明ナラズ．如斯キ白血球減少時ニアリテモ核形推移係 數ハ著明二上昇シ， 1 時間後二於テモ埥二多數ノ桿狀型細胞キ諗ムルノネナラズ，幼若型細胞

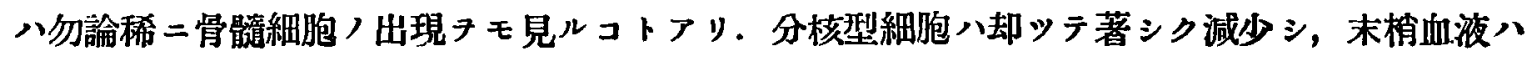
一時㱠ド桿狀型及ビ幼若型細胞ニヨツテ占メラルルノ狀態トナル。カカル事實八枸䋇酸曹達が

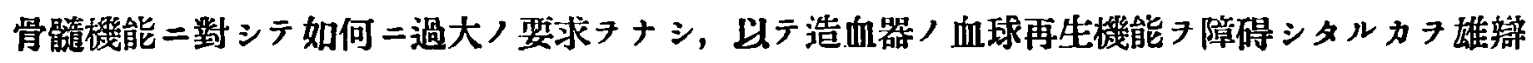

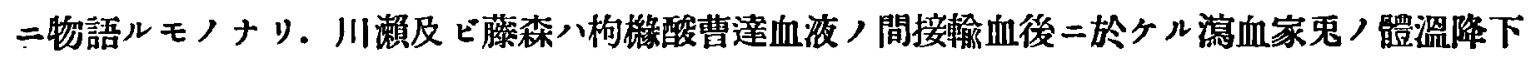
八直接輸血二比シ急激ニシテ且著明ナリト云ヘリ．余モ枸格酸曹達血液＼cjkstart間接輸血ノ場合二八 一時體溫ノ下降スルタ認メタルモ, 該下降ハ一般二暧度ニシテ $2-4$ 時間後二八反對二著明ナル 上昇ヨ示シ, 本上昇八直接輸血二比シ却ッテ高度ニシテ, $1^{\circ} \mathrm{C}$ 上上ノコト多ク, 殊二該注入血液 ノ冾却セル場合二八顝溫ノ下八降、勿論續イテ起ル上昇モ亦著明ナリ。而シテ其ノ持續モ比較 的長ク 6-7 時間後二八向ホ平溫二復セザルモノ多シ. 余モ枸格酸曹達血液ノ間接輸血法二於 テハ體溫ノ變化甚ダシキ缺陷アルコトタ知レリ．省ホ全身反應症狀モ直接輸血二比シ頻發且高 度ナルハ, 緒諭二於テ述ベタルガ如ク, 先簐諸氏, 既二認メタル所ニシテ, 余モ亦臨伢實䲆上

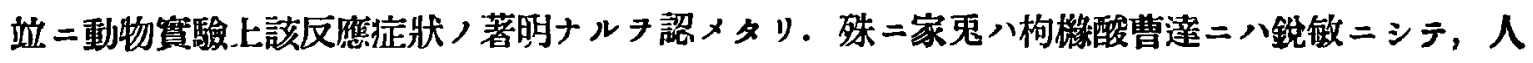
體二比シ枸保酸曹達反應八著明ナリ。シカシ健常家鬼卜失血性貧血家鬼卜ノ間二八，一部學者 (Henderson u. Haggard (133)) ノ稱スルガ如キ著明ナル差違タ認メズ. 余八 Joannidas,

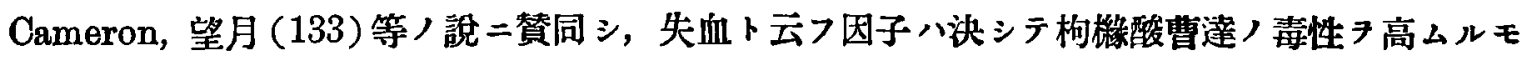
ノニ非ズト信ズ．サレド枸楼酸曹達反應八該液ノ注入速度二八關係スルコト勿論ニシテ, 急速

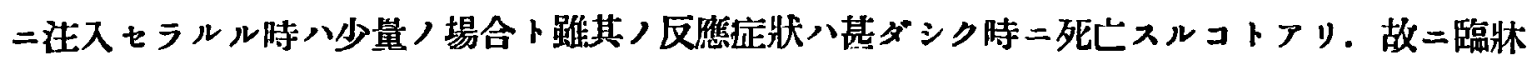

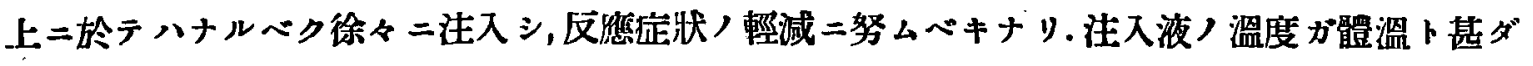
シキ差暴アル時ハ, 生理的食監水ノ注入二際シテモ, 何等ノ良果キモ期待シ得ザルノミナラズ, 
却テ生體二對シテ障碍的影暗タ與フル者ナルハ, Knoll (110), 鶴省 (110), 上井 (135), 島 (154)

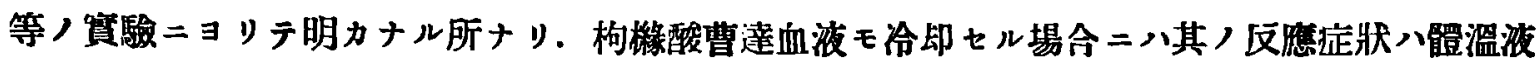
ノ場合二比シ著明ナルコトハ勿論ニシテ體溫,下降，上昇共二甚ダシク，白血球總數ノ減少モ 亦著明ニシテ且陰性現象長シ，從ッテ傜「エ」啫好細胞，淋巴球及ビ單核細胞等ノ減少度著明二 シテ, 生體二對スル障碍的影整八明カ二高度ナルタ知レリ. 余 (161) 八臨牀的研究ノ成績二於 テハ白血球總數ノ㘿減區々ニシテ一定七ザリシハ, 全ク此㓌性現象ノ强弱長短二由爽スト考人 ラル. 即チ臨林上ニテハ動物實驗ノ如ク溫度的二检查特刻ノ正確フ常二期シ得ザリシハ止ムタ 得ザル所ナリ．直接輸血法ニテハ注入血液ノ溫度ニ就キテノ注意八全ク不用ナルテ，間接輸血

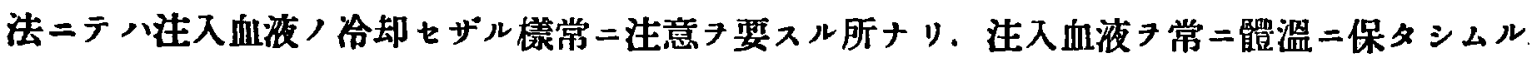
コトハ, 間接輸血法殊二构株酸曹達血液ノ場合ニハ, 同法二於々ル忌ムべキ反應症狀尹輕減セ シムルニ肝要ニシテ，些湅ナルコトナガラ注入速度ト共二臨林上注意フ要スベキコトナリ。

脫織血淮ノ有海ナルハ既二周知ノ事賽ナルモ，該血液ノ毒性八時ノ經過卜共二著シク減退ス ルハ, Moldovan (83), Freund (35) ノ實驗ニヨルモ明カナリ. Freund /家鬼二於ケル實驗二

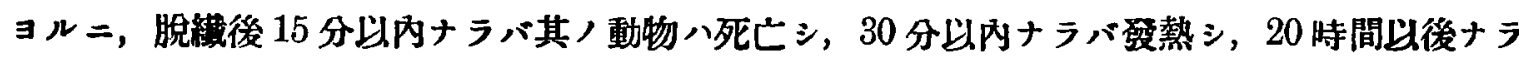

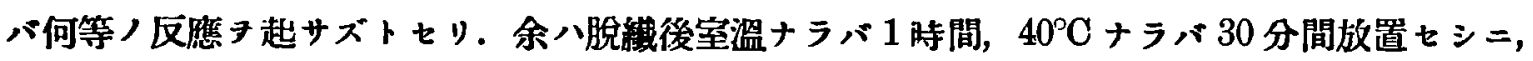

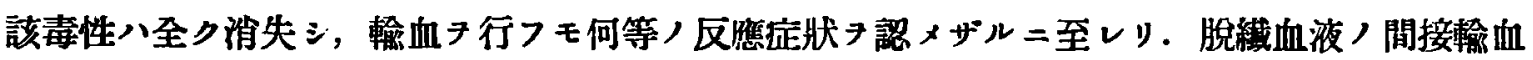

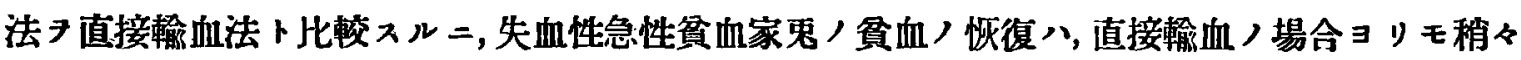
逰延スルモノノ如キモ，白血球像二八著明ナル差違フ認×難ク，且體溫二就キテモ甚ダシキ差

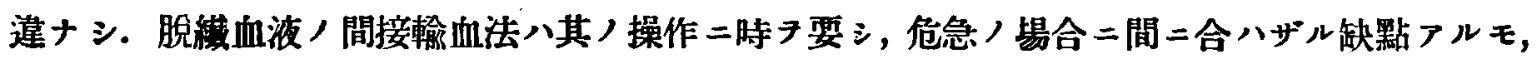
大體二於テ直接輸血法二比シ甚ダシキ逬色ナシ．枸熪酸曹達血液ノ間接輸血法ト比較スル二, 脫織血液ノ間接法ノ却ッテ勝レルキ知レッ(第 58 表參照).

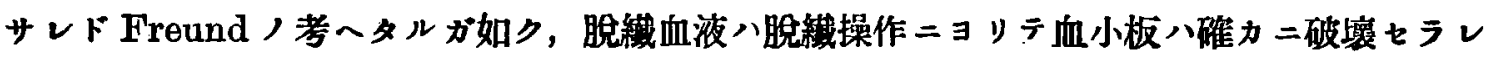

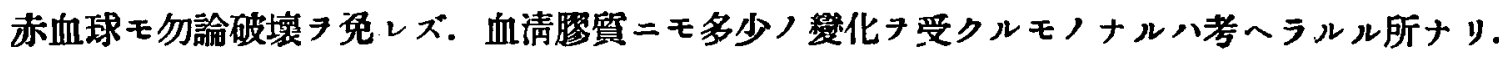
シカシSeifert (133) 八脫㵶血液二八酸素ヲ含ムコト多キガ故ニ却ッテ好都合ナリトシ, Platt

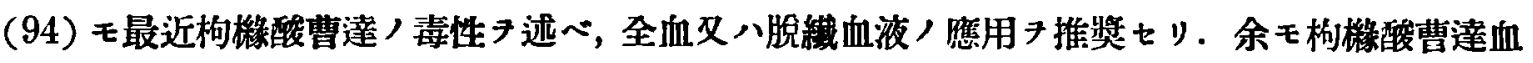
波ノ間接輸血法ニ八上述ノ如キ,種タナル障碍的影響ノ缺陷アルタ認メ，間接輸血法二於テハ Plattノ言へルガ如ク，脫織血液ノ間接法ノ寧口勝レルォ信ズ.

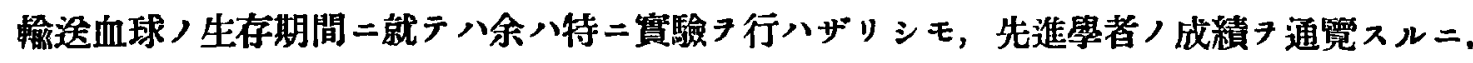
最短 7 日 (Tice (133))，最長 59-119日（Wearn (133)) ニシテ，同種間ニ於テハ大䯏 3-4 週 間八生存スルモノ，如シ. 余ノ輸血例二就テ考フルモ，輸血血球八同種間二於テハ相當ノ生存 期間ヌ有スヘク，少クトモ數日閒ハョク其ノ生理的機能き代償シ得ベシ. 而シテ其ノ破㙥產物 八造血器ノ血球再生機能 促進スルモノニシテ，䝷血ノ恢復機能タ速ナラシム。

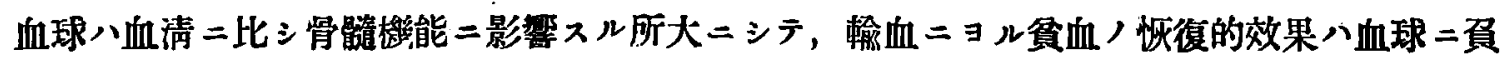
フ所大ナリ．而シテ血清ノ作用ハ働性ト非働性トノ間二著明ナル差違ナシ。 


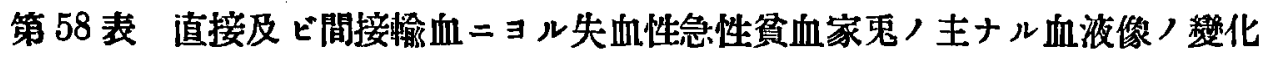

\begin{tabular}{|c|c|c|c|c|c|c|c|c|c|}
\hline \multirow{2}{*}{ 輸血法／種類 } & \multicolumn{2}{|c|}{ 貢血 >恢復日慜 } & \multirow{2}{*}{$\begin{array}{c}\text { 白血球 } \\
\text { 總 致 }\end{array}$} & \multirow{2}{*}{$\begin{array}{l}\text { 焚形推 } \\
\text { 移係数 }\end{array}$} & \multirow{2}{*}{ 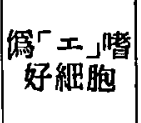 } & \multirow{2}{*}{ 淋巴球 } & \multirow{2}{*}{$\begin{array}{l}\text { 單榜細胞 } \\
\text { 专移行型 }\end{array}$} & \multirow{2}{*}{ 體 盢 } & \multirow{2}{*}{ 反應昰狀 } \\
\hline & 赤血球數 & 血色素融 & & & & & & & \\
\hline 直接鐱血法 & $\stackrel{5-7 \text { 日 }}{\text { 多 } 9 \text { 日 }}$ & $\begin{array}{l}7-9 \text { 日 } \\
\text { 多ク }\end{array}$ & 著㙕 & 上昇著明 & 著增 & 一時稍減 & 著㙕 & $\begin{array}{l}\text { 上昇牼度 } \\
\text { 持縝短 }\end{array}$ & 無 \\
\hline $\begin{array}{c}\text { 构樌䣬曹達血液 } \\
\text { 間接輸血法 }\end{array}$ & $\begin{array}{c}7-9 \\
\text { 多》 } \\
\text { - } 8 \text { 日 }\end{array}$ & $\begin{array}{c}9-10 \text { 日 } \\
\text { 多クハ9日 }\end{array}$ & $\mid$\begin{tabular}{|} 
一時著裁 \\
後著剒
\end{tabular} & $"$ & 一侍著减 & 一時蓕減 & \begin{tabular}{|c|} 
一時著減 \\
後增
\end{tabular} & $\begin{array}{l}\text { 一時下降 } \\
\text { 後上昇著 } \\
\text { 持演長 }\end{array}$ & 著明 \\
\hline 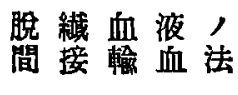 & $\underset{6-8}{\text { 日日 }}$ & $\begin{array}{c}8-9 \text { 日 } \\
\text { 多ク } 9 \text { 日 }\end{array}$ & 著箸 & $"$ & 著增 & $\mid$\begin{tabular}{|} 
一時稍淢 \\
後稍增
\end{tabular} & 堽 & $\mid \begin{array}{c}\text { 上昇輕度 } \\
\text { 持积短 }\end{array}$ & 無 \\
\hline
\end{tabular}

生理的食䜿水 注入ニヨリテモ造血器/血球再生機能八多少促進七ラルルモノニシテ, 貧血 ノ恢復二モ生理的食監水ノ注入八相當ノ效果アルモノノ如ク，失血性急性盆血後二於ヶル該液

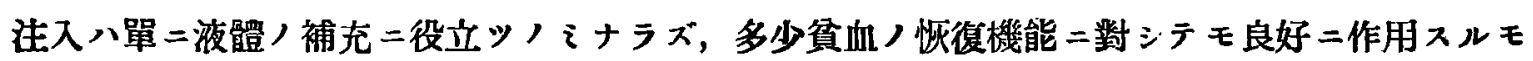
ノナリ。

以上ノ動物筫䁩ノ結果尹直チニ人體二應间シ，批制セントスルハー考尹要スル所ナリ。殊二

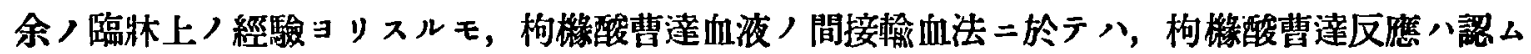

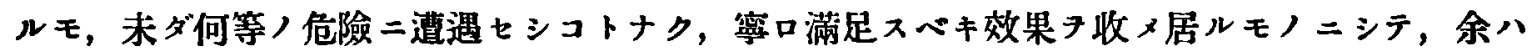

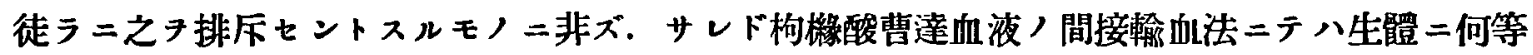

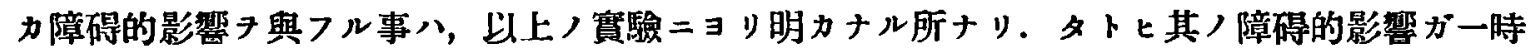

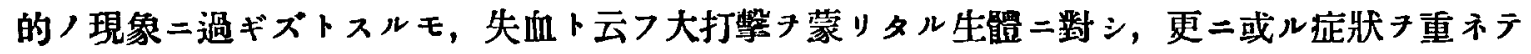
其ノ負擔习重カラシムルコトハ明カニ有害ニシテ, 決シテ直接輸血法二勝レリト云フ可カラズ. 枸格酸曹達血液八間接輸血法八直接輸血法ニ比シテ：唯技術ト手數ノ比較的容易簡單ナル長所

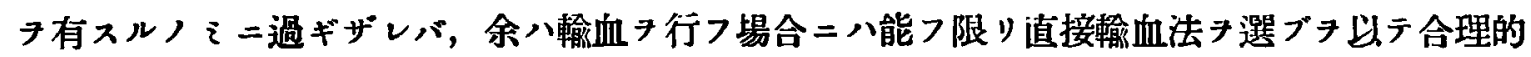
ナリト思考ス。

\section{第 5 章結 論}

1）失血性急性貧血ノ處置トシテハ, 輸血法ハ最モ合理的ニシテ, 造血器ノ血球再生機能八 著シク促進シ，貧血，泚復八勘ダシク速ナリ，就中直接榆血法八副作用全クナク最モ推獎スべ キ良法ナリ。

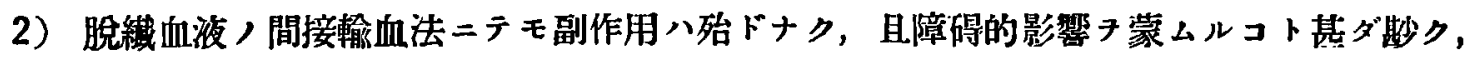
直接輸血法二比シテ甚ダシキ称色ナシ.

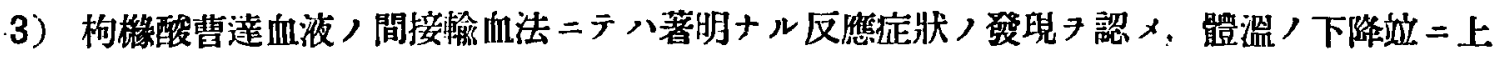

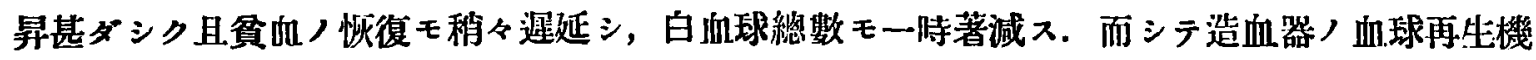

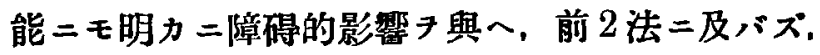

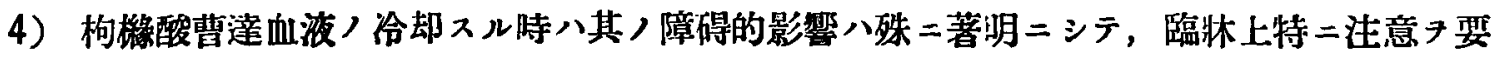
z. 


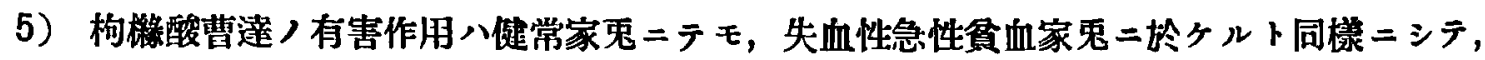

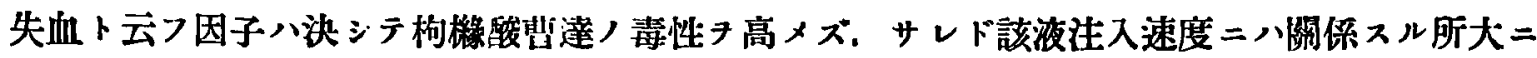
シテ, 出來得ル限り徐々二注入スルフ旰要トス。

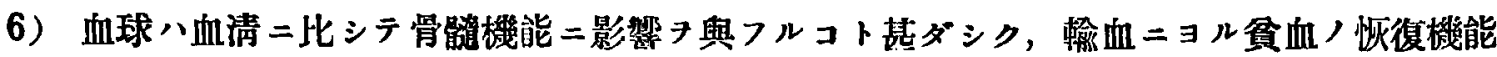

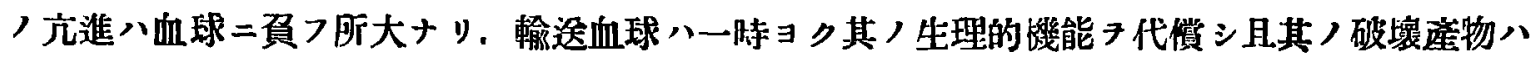
造血器ノ血球再生機能ヨ促進スルモノナリ。血清ノ作用八働性ト非働性トノ間二著シキ差違ナ シ.

7）生理的食辟水注入ニョリテモ骨娟道機能八多少䒕進シ，失血性急性資血／際二於テ八單二 液體 ノ補充二役立ッノミナラズ，多少貧血ノ恢復機能二モ良好二作用スルモノナリ．

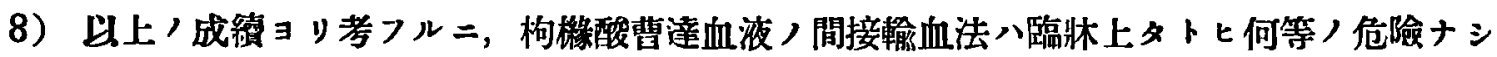
トスルモ，種々ナル障碍的因子ノ存在スルハ事實ニシテ，直接输血法二比シテ八唯技術卜手數 ノ比較的容易簡單ナル長所アルノ フ選ブァ以テ合理的ナリト思考ス.

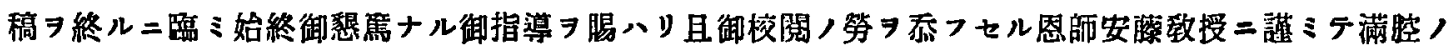
謝意习表ス. (5. 2.1. 受稿)

\section{主 要 文 獻}

1) Antekonenko, cit. n. 井户. $\quad$ 2) Ascoli, M. med. W. Nr. 31, S. 1239, $1901 . \quad$ 3) Ashby, Journ. of exper, med. Vol. 34, No. 2, p. 127, $1921 . \quad$ 4) Bernhein, Journ. of the americ. med, assoc. Vol. 61, No. 4, 1913 . 5) Bernheim, Jouru. of the americ. med, ussoc. Vol. 77, No. 4, p. 275, 1921 . 6) Bittner, eit. n. 多田羅. $\quad$ 7) Blumenthal u. Morawitz, D. A. f. kl. Med. Bd. 90, S. 132, 1907. 8) Blumenthal u. Morawitz, D. A. f. kl. Med. Bd. 92, S. 25, 1908 . 9) Bock, Arch. f. exp. Path. u. Pharm. Bd. 68, S. 1, 1912. 10） Bonsdarff, eit. n. 日野. 11）Burnet,, eit. v. 多田羅. 12）Cannon, Fraser und Hoope, Journ. of the americ. med. assoc. Vol. 70, p. 526, 1918. 13) Coenen, M. med. W. Nr. 1, S. 1, 1918. 14) Davidsohn u. Friedenann, Arch. f, Hygiene, Bd. 71, S. 16, 1909. v. Decastello und Sturli, M. med. W. No. 26, S. 1090,1902 . 16) Döderlin, D. med. W. Nr. 17, S. 449, 1920. 17) Domarus, Arch. f. exper. Path. u. Pharm. Bd. 58, S. 319, 1909. 18) Donath, Wien. med. W. Nr. 22, S. 497, $1900 . \quad$ 19） Donath. u. Landsteiner, Wien. kl. W. Nr. 30, S. 713, $1901 . \quad 20$ ) Drinker u. Brittingham, Arch. of Int. med., Vol. 23, No. 2, p. 133, $1919 . \quad$ 21) v. Dungern u. Hirschfeld, M. med. W. No. 11, 8. 741, 1910. 22) Dieselle, Zeitschr. f. Immunitätsforsch. u. exper. Therap. Orig. Bd. IV, S. 531, $1910 . \quad$ 23) Dieselbe, Ebendu, Bd. VI, S. 284, 1910. 24) Dieselbe, Ebenda, Bd. VIII, S. 526, 1911. 25) Ehrlich u. Lazarus, Zeitschr. f. kl. Med., Bd. 35, S. 387, 1898 26) Eisenberg, W. kl. W. S. 1020, 1901. 27) Ellermann u. Erlandsen, D. A. f. kl. Med., Bd. 100, S. 455, 1910.28 28) Dieselbe, Arch. f. exper. Path. u. Pharm., Bd. LXIV, S. 28, 1911. $155,1900$. 
32) Feri, oit. n. Bock. 33) Freund, Arch. f. exper. Path. u. Pharm., Bd. 65, 8. $227,1911$.

Freund, D. A. f. lkl. Med. Bd. 105, S. 44, 1912 . 35) Derselle, M. med. W. Nr. 34, S. 976, $1919 . \quad 36)$ Derselle, Kl. W. Nr. 24, S. 1218, u. Nr. 25, S. 1272, 1922. 37) Frothingham and Mionot, Americ. Journ. of Physiol. 30, 6, p. $430 . \quad$ 38) Garbat, Jonrn. of the americ. med. nsssoc., Vol. LXVI, p. 1543.1916. 39) Gichner, Journ. of the americ. med. assoc., Vol. 88, No. 12, P. 893, 1927. 40) Goltz, Virchow's Arch., Bd. 29, S. 394, 1864. 41) Goodall, Journ. of Path. a. Bakt. Vol. 14, P. 195, 1910 . 42) Grawita, D. med. W. No. 35, S. 585, 1899 4 43) Derselbe, Berl. kl. W. No, 7, S. 153, 1900.44$)$ Derselle, D. med. W. No. 52, S. 908, 1901 45) Derselbe, Berl. k]. W. No. 24, S. 641, u. No. 46, S. 1171, 1901.46$)$ Derselbe, M. med. W. S. 1659, 1910. 47) Derselbe, Klinische Path. d. Blutes, 4 Aufl., S. 179-187, 1911. 48) Gruber, Arch, f. exp. Path. u. Pharm., Bd. 58, S. 289, 1909. 49) Haecker, Jahresbericht über d gesamte chir. u. ihre Grenzgebiete, 29 Jabrg., 5. 12, 1915. 50) Hayem, cit. n. 井F. 51) Hempel, Bruns Beitraege z. Klin. Chir., Bd. 132, 8. 7, 1924. 52) Hirsch, D. med. W. Nr. 31, S. 1302, $1926 . \quad$ 53) Hühnerfauth, Virchow's Arch. Bd. 76, S. 310, $1879 . \quad$ 54) Itami, Arch. f. exp. Path. u. Pharm. Bd. 60, S. 76, 1908. 55) Derseibe, Ebenda. Bd. 62, S. 93, 1909. 56) Japha, Jb. f. Kdkb. Bd. 52, S. 242. 57) Jansky, Jb. f. Neurul. u. Psych., S. 1028, 1907. 58) Jazwein, Berl. kl. W. Nr. 35, s. 901, 1901. 59) John, M. med. W. No. 4, S. 186, 1912 . 60) Jo, Verh. d. jap. Path. Gesells., S. 113, 1916. 61) Judd, Med. record., Bd. LXXXVII, Hft. 16, $1915 . \quad 62)$ Krlein, W. kl. W. Nr. 16, S. 413, 1902. 63) Klieneberger $u$. Carl, Zbl. f. innere Med., S. $601-625,1910 . \quad$ 64) Kobryner, Zeitschr. f. kl. Med., Bd. 102, s. 470, 1926. 65) Koeppe, M. med. W. Nr. 39, 1895. 66) Kondo, Actr Schol. Med. Univ. Imp. in. Kioto, Vol. 3, p. 169, $1919 . \quad$ 67) Krehl, Arch. f. exp. Path. u. Pharm., Bd. 35, S. 226, 1895. 68) Laache, cit. n. 井F. 69) Landsteiner, M. med.W. Nr. 46, 1132, $1901 . \quad 70)$ Landsteiner, Zbl. f. Belkt,. Purnsitenk. u. Infektionsk. Bd. 27, S. 361, $1900 . \quad 71)$ Landsteiner, M. med. W. No. 42, S. 1812,1903 . 72) Lazarus, cit. n. \#F. 73) Lederer, Surg. Gyecol. a. Obstetr. Vol. 37, p. 221, 1923 . 74) Lewisohn, M. med. W. Nr. 21, S. 7(18, 1915 . 75) Derselbe, Surg. Gynecol. i. Obstetr, Vol. 21, No. 1, p. 37, $1915 . \quad 76)$ Derselbe, Ann. of Surg., Vol. LXIV, p. 618, $1916 . \quad 77)$ Derselbe, Amelic. jour. of med. scien., Vol. 157, No. 2, p. 253, $1919 . \quad$ 78） Derselbe, Amer, journ. of Surg., Vol. 36, No. 4, S. 83, 1922. 79) Iindsay S. Milne, D. A. f. kl. Med., Bd. 109, S. 401, 1913. 80) Loewit, cit. n. 多田羅. 81) Lyon, Virchow's Arch. Bd. 84, S. 131, 1881 82) Maydl, cit. n. 井戶, 83) Moldovan, M. med. W. No. 52, S. 2422,1910 . 84) Mole, Journ. of Path. u. bact. Vol. 28, p. 637, 1925. 85) Morawita, Arch.f. exp. Puth. u. Pharm., Bd. 60, S. 298, $1908 . \quad$ 86) Morawitz u. Itami, D. A. f. kl. Med., Bd. 100, S. 191, $1910 . \quad$ 87) Morazitz u, Pratt, M. med. W. No. 35, S. $1817,1908$. 88) Moss, Bull. of Johns Hapkins hosp. 21, 63,1910 (Folin Serol. 5, 267, 1910). 89) Naegeli, Blutkrakheiten u. Blutdiagnostik, 1923 90) Nather z. Ochsner, Arch. f. kl. Obir., Bd. 132, S. 420, 1924. 91) Niklas, Klin, W. Nr. 23, S. 1187,1922 . 92) Opitz, D, med. W. Nr. 4, S. 120, $1923 . \quad$ 93) Otto, Pflïger's Arch., Bd. 36, S. 12-72, 1885. (94 Platt, The Luncet., Vol. CCX, p. 173, 1926. 95) Rieder, cit. n. \#戶. 96) Rossius, Arch. f. klin. Chir. Bd. 137, S. 583, 1925. 97) Rubinstein, Zeitschr. f. kl. Med., Bd. 42, S. 161, $1901 . \quad$ 98) Sahli, Kl. Untersuchungsmethoden, $1920 . \quad$ 99) Schauman u. Rosenqvist, Zeitschr. f. kl. Med., Bd. 35, S. 126-314, $1898 . \quad$ 100) Schauman u. Willebrand, B. kl. W. Nr. 1, 8. 9, 1899. 101) Schilling, Das Blutbild und seine kl. Verwertung, 1924. 102) Scholten, Praktische Ergebinsse d. Geb. u. Gyn. 9 Jg. Hft. 2, S. 65, 1922. 103) Schwenkenbecher u. Siegel, D. A. f. kl. Med., Bd. 92, S. 303, 1908. 104) Shattock, Journ. of Pathol. u. bact. 6, 303, 1900 . 105) Siegel, D. A. f. kl. Med., Bd. 92, $1903 . \quad$ 106) Smith, in Grawitz; Klinische Pathol. des Blutes S. 89, 1911 , 
107) Tallqvist, Zeitsohr. f. kl. Meri. Bd. 61. S. 427, 1907.

108) Tallquist u. Willebrand, Skandinav. Arch. f. Physiol. Bd. X, S. 37, 1900. 109) Torii, Mitteilungen aus d. Med. Fakultait d. Kaiserlichen Kyushu-Univ., Bd. VII, 1923. 110) Tsurzmaki, Aota Sohol. med. Univ. imp. in Kioto, Vol. V, p. 303, 1922. 111) Tï̌rk, cit. n. 井戶. 112) Türk, Wien, kl. W. Nr. 6, S. 157, $1907 . \quad$ 113) Unger, Journ. of the americ. med. assoc., Bd. $73,815,1919$. 114) Unger, Journ. of the americ. assoc. Vol. 77, 2107, 1921. 115) Vdgo,, Zbl. f. Gyn. 44 Jg., No. 39. S. 1087, 1920. 116) Weil, Journ. of the amer. med. assoc., Vol. LXIV, p. 425, $1915 . \quad$ 117) Weszecksky, Biochem. Zeitschr., Bd. 107, S. 159, 1920. 118) Wichern u. Piotrawiski, M. med. W., Nr. 29, S. 1619, 1912. 119) Willebrand, oit. n. 井戶. 120) Würth, Arch. f. Physiol., S. 447, 1911. 121) Zangemeister, B. kl. W. No. 20, S. 943,

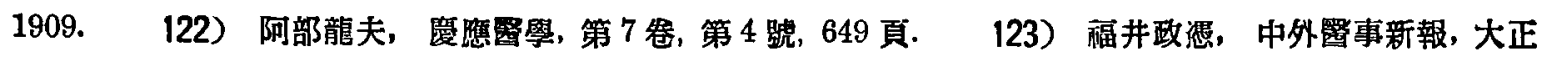

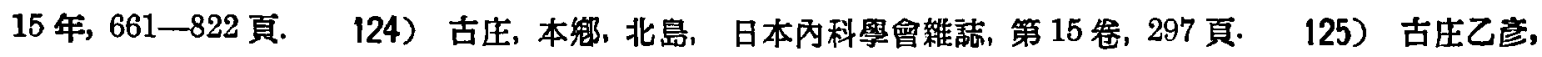

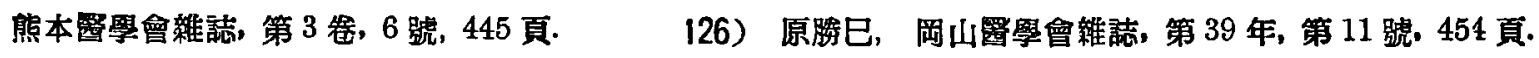

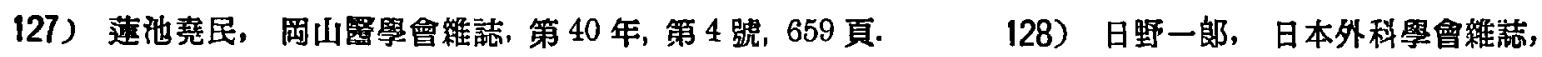

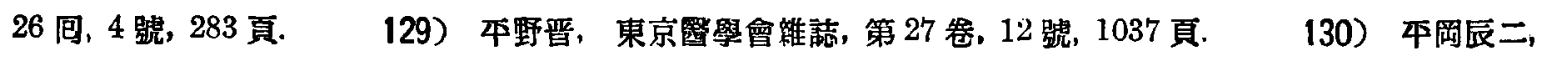

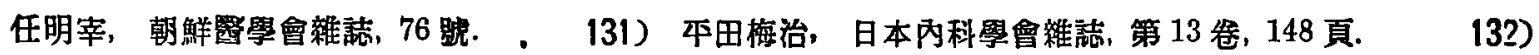

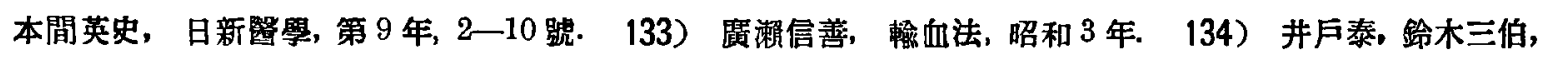

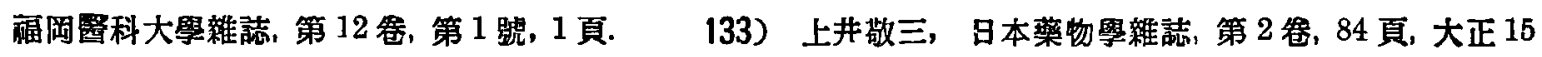

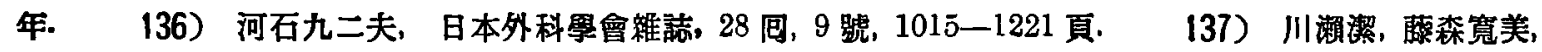

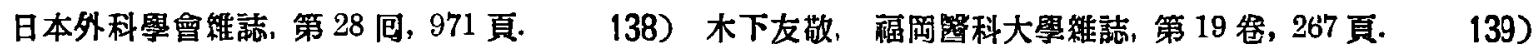

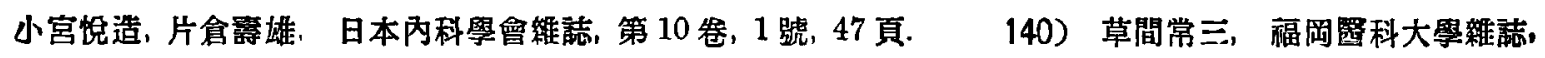
第 7 卷, 148 頁. 141）皆本泰一郎，日本外科學會雜誌，21 包，93 頁. 142）操坦水，日本微生物 學會雜誌，第 21 卷，第 6 號，1336 頁， 143）永井静，日本微生物學會雜誌、第 18 爸，第 4 號. 144）

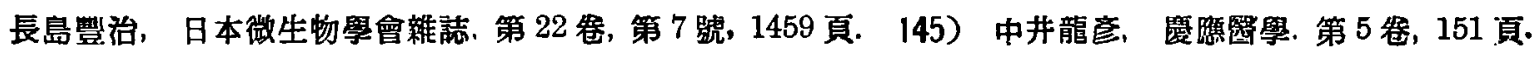
大正 14 年. 146）西下正巳, 岡山學學會雜誌, 第 40 年, 10 號, 2148 頁. 147）小田俊郎, 北海道

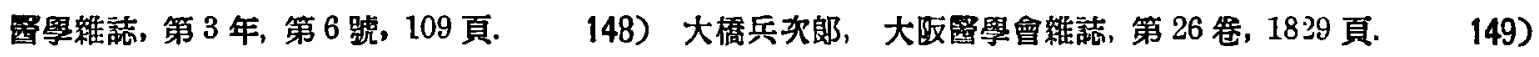

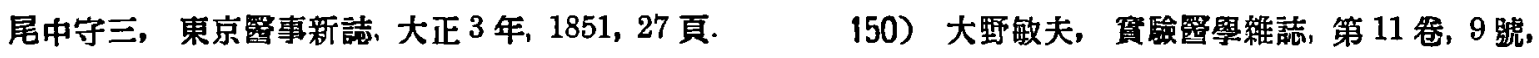

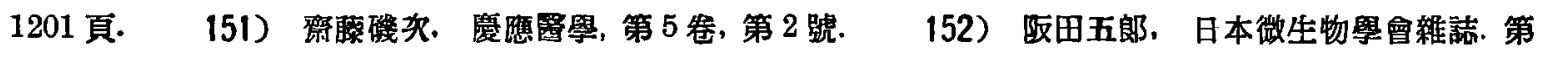
19 失, 第 6 號, 883 頁. 153）重时常清, 北海道學學雜誌, 第 3 年, 第 4 號, 1 頁. 154）島誠郁，十 全會雜誌, 第 32 卷, 昭和 2 年, 305 頁. 155） 鉿木平十郎, 日本外科學會雜誌, 14 回, 31 頁. 156)

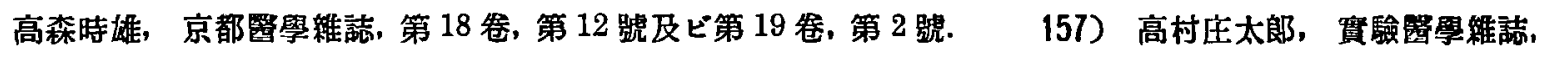

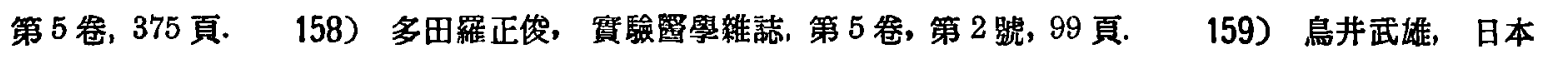

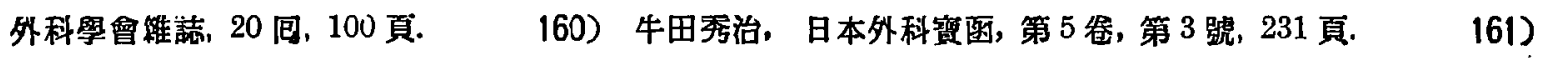
八木齊，日本婦人科學會雜誌，第 23 卷，第 6 號，54 頁. 
Kurze Inhaltsangabe.

\title{
Vergleichende Untersuchung des Blutbildes der direkten und indirekten Bluttransfusion für acute Verblutungsämie.
}

\author{
Von \\ Hitoshi Yagi. \\ Aus der Universitäts-Frauenklinik in Okayoma, Japan. \\ (Vorstand : Prof. Dr. K. Ando.) \\ Eingegangen am 1. Februar 1930.
}

In der vorigen Mitteilung berichtete ich, dass bei indirekter Bluttransfusion mit Citratblut das Blutbild einen deutlichen, wenn auch nur vorübergehenden, schädigendeń Einfluss zeigt.

In dieser Mitteilung nehme ich Bezug auf eine weitere vergleichende Untersuchung der direkten und indirekten Bluttransfusion, die ich vorgenommen habe. Für diese Zwecke habe ich direkte und indirekte Bluttransfusion bei Kaninchen mit acuter Verblutungsanämie ausgeführt, um ihren Einfluss auf das Blutbild, besonders auf die blutbildende Funktion der blutbildenden Organe zu vergleichen. Es gelang mir, die Ergebnisse in folgender Weise zusammenzufassen :

1. Bei der Behandlung der acuten Verblutungsanämie ist die Bluttransfusion am rationellsten. Sie fordert nämlich die Blutbildungsfunktion der blutbildenden Organe deutlich, infolgedessen erholt sich die Anämie sehr schnell wieder. Es ist hervorzuheben, dass von den beiden Methoden die direkte Transfusion keine Nebenerscheinung hat, daher am empfehlenswertesten ist.

2. Auch die indirekten Bluttransfusion mit defibriniertem Blut zeigt fast keine Nebenerscheinungen; dazu kommt, dass das Blutbild nur einen minimalen schädigenden Einfluss zeigt, daher steht sie der direkten Methode nicht so sehr nach.

3. Bei der Transfusion mit Citratblut tritt eine deutliche Reaktionserscheinung zu Tage. Die Korpertemperatur erfährt ein deutliches Fallen und Steigen, und ausserdem verspätet sich auch mehr oder weniger die Wiedererholung der Anämie. Die Leukozytenzahl vermindert sich vorübergehend deutlich. Auch die die Blutkorperchenbildende Funktion der blutbildenden Organe erfährt einen schädigenden Einfluss. Wegen dieser Schädigungen steht sie daher den oben erwähnten zwei Methoden nach.

4. Beim Kühlwerden des Citratblutes wird die schädigende Wirkung besonders deutlich, so dass man bei klinischer Behandlung besondere Vorsicht in dieser Hinsicht gebrauchen sollte. 
5. Die schädigende Wirkung des Natr. citrat. ist auch bei gesunden Kaninchen die gleiche wie bei Kaninchen mit acuter Verblutungsanämie. Daraus konnen wir erkennen, dass der Faktor "Verblutung" keinesweges die Giftigkeit von Natr. citrat. verstärken kann. Dagegen steht diese in innigem Zusammenhang mit der Geschwindigkeit, mit welcher man die betreffende Flüssigkeit einverleibt. Es ist darauf zu achten, dass man sie moglichst langsam injiziert.

6. Blutkorperchen haben auf die Funktion des Knochenmarkes einen günstigeren Einfluss als Blutserum. Daher verdankt man die gesteigerte Funktion des Knochenmarkes für die Wiedererholung bei Anämie in ganz besonderer Weise den Blutkorrperchen. Transfundierte Blutkörprechen halten vorübergehend die physiologische Funktion kompensatorisch für verlorengegangene Blutkörperchen aufrecht. Ihre Zersetzungsprodukte konnnen die blutbildende Funktion der blutbildenden Organe fordern. Das serum zeigt in seiner Wirkung keinen deutlichen Unterschied zwischen inaktiviertem und aktiviertem Serum.

7. Auch durch die Injektion der physiologischen Kochsalzlősung wird die Funktion des Knochenmarkes mehr oder weniger gesteigert, bei der acuten Verblutungsanämie ersetzt sie nicht nur verlorengegangenen Korpersaft hinreichend, sondern hat auch eine mehr oder weniger günstige Wirkung für die Wiedererholung der Anämie.

8. Aus den oben erwähnten Ergebnissen kann man hervorheben, dass die indirekte Bluttransfusion mittels Citratblutes, wenn sie auch klinisch ohne Gefahr ausführbar ist, doch verschiedene schädigende Faktoren besitzt ; zu ihren Gunsten spricht nur, dass sie mit verhältnismässig wenig Kunst und Mühe ausführbar ist. Daher kann ich behaupten, dass es am rationellsten ist, bei Ausführung der Bluttrasfusion die direkte Transfusion zu wählen. (Autoreferat.) 